\author{
UNIVERSIDADE DE SÃO PAULO \\ FACULDADE DE CIÊNCIAS FARMACÊUTICAS \\ PROGRAMA DE PÓS-GRADUAÇÃO EM FARMÁCIA \\ (FISIOPATOLOGIA E TOXICOLOGIA) \\ ÁREA DE ANÁLISES CLÍNICAS
}

Relação ancestral e pan-resistoma plasmidial de Escherichia coli produtora de CTX-M-8 e MCR-1 na interface humana, animal e ambiental

Miriam Rodriguez Fernandes 


\author{
UNIVERSIDADE DE SÃO PAULO \\ FACULDADE DE CIÊNCIAS FARMACÊUTICAS \\ PROGRAMA DE PÓS-GRADUAÇÃO EM FARMÁCIA \\ (FISIOPATOLOGIA E TOXICOLOGIA) \\ ÁREA DE ANÁLISES CLÍNICAS
}

Relação ancestral e pan-resistoma plasmidial de Escherichia coli produtora de CTX-M-8 e MCR-1 na interface humana, animal e ambiental

Miriam Rodriguez Fernandes

Versão original

Tese para obtenção do Título de DOUTOR

Orientador: Prof. Dr. Nilton Lincopan

São Paulo

2019 
Miriam Rodriguez Fernandes

Relação ancestral e pan-resistoma plasmidial de Escherichia coli produtora de CTX-M-8 e MCR-1 na interface

humana, animal e ambiental

Comissão Julgadora da

Tese para obtenção do grau de DOUTOR

Orientador: Prof. Dr. Nilton Lincopan

$1^{\circ}$ Examinador

$2^{\circ}$ Examinador

$3^{\circ}$ Examinador

São Paulo

2019 
À minha amada mãe (in memoriam), nem o tempo faz cicatrizar essa ausência, cercada de saudade e amor presente.

À minha “abuelita" Preciosa, por todo seu amor Ao meu pai, por sempre estar ao meu lado em todas as minhas escolhas À minha querida irmã que me deu o amor da minha vida, minha sobrinha Giovana. 


\section{AGRADECIMENTOS}

Ao meu orientador Prof. Nilton Lincopan, obrigada pela oportunidade, apoio e confiança em meu trabalho.

À Dra. Alessandra Carattoli pelos conhecimentos compartilhados e a hospitalidade durante minha estadia no Istituto Supeirore di Sanità (ISS).

Aos Pesquisadores e funcionários do ISS, especialmente à Laura Villa e Aurora García-Fernandez, pela recepção e ajuda durante este período.

À Prof. Rosa Maria (UNIFESP), pelos ensinamentos iniciais com os experimentos de análise plasmidial.

Ao John McCulloch e Juliana Pérez-Chaparro, pela amizade, colaboração e ensinamentos transmitidos nos experimentos de sequenciamento de nova geração.

Ao Tiago Souza e Suzan Ienne, pela ajuda no preparo das bibliotecas genômicas para os experimentos de sequenciamento de nova geração.

Á Louise Cerdeira pelo auxílio na parte de Bioinformática.

À Quézia Moura por sua bondade e amizade verdadeira em todos os momentos em que precisei, levo você para minha vida!

Aos amigos Fábio Sellera, Daniel Monte, Caetano Sabino, Marcelo Carvalho, Marcos Cunha e Andrey Sacramento por todas as colaborações, discussões acadêmicas, enriquecimento intelectual e bons momentos compartilhados.

À minha querida companheira de laboratório Maria Muñoz pela amizade, apoio e confiança, e aos demais colegas de laboratório: Luciana Sartori, Luana Melo, Ralf Lopes, Brenda Cardoso, Fernanda Esposito e às nossas queridas agregadas Carol dos Anjos e Meire Silva. 
À Milena Dropa pela amizade, colaboração e a disponibilidade em sempre ajudar.

À Viviane Nakano minha "mãe" científica, obrigada por todos os ensinamentos compartilhados e por estar presente em todas as fases da minha vida acadêmica. Sou muito grata ao seu carinho, amizade e confiança.

À Vanessa Bueris pela amizade e ensinamentos compartilhados desde o meu início na vida acadêmica.

As minhas queridas amigas da vida: Juliana Pinhata, Caroline Pouza, Thalita Tarrazo, Isabella Pellacani, Brunna Oliveira, Flávia Lavieri, Larissa Torres e Karina Rocha, por serem minha família em São Paulo, pelas alegrias e bons momentos vividos, sem vocês minha sanidade mental estaria prejudicada.

Aos ex-técnicos do laboratório: Celminha, Isis e Tadeu pela amizade e alegrias compartilhadas durante esses anos.

Aos secretários da pós-graduação da FCF-USP e do ICB-USP.

A todos os professores do Departamento de Microbiologia ICB-USP e de outros departamentos da Universidade de São Paulo pelos ensinamentos compartilhados que foram importantes para minha formação acadêmica.

À CAPES pelo suporte financeiro de bolsa no país

À Fundação de Amparo à Pesquisa de São Paulo pelo suporte financeiro concedido de bolsa no país e BEPE (2015/13527-2 e 2017/16754-5).

Finalmente, a todos que contribuíram direta e indiretamente para realização deste estudo.

\section{Muito Obrigada!}




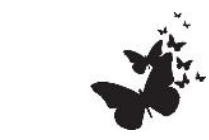

"A ciência para mim, explica parte da vida... se baseia em acontecimentos, experiências e experimentos".

Rosalind Franklin

"Eu sou um daqueles que pensam que a ciência tem uma grande beleza”.

Marie Curie 


\section{RESUMO}

FERNANDES, M. R. Relação ancestral e pan-resistoma plasmidial de Escherichia coli produtora de CTX-M-8 e MCR-1 na interface humana, animal e ambiental. 2019. 142f. Tese (Doutorado) - Faculdade de Ciências Farmacêuticas, Universidade de São Paulo, São Paulo, 2019.

Linhagens de Escherichia coli produtoras de $\beta$-lactamase de espectro estendido (ES $\beta \mathrm{L})$ do tipo CTX-M são endêmicas no Brasil, sendo prevalentes em casos de infecções hospitalares e ambulatoriais. Atualmente, cepas produtoras de CTX-M têm sido recuperadas de ambientes urbanos, animais de companhia ou de produção e de alimentos de origem animal, inclusive afetando o agronegócio, o que aponta uma possível rota de disseminação em diferentes ecossistemas. Recentemente, nesta espécie, foi descoberto um novo gene, chamado de $m c r-1$, que confere resistência transferível à colistina, um dos últimos antibióticos eficazes para o tratamento de infecções causadas por bactérias produtoras de ESBL e carbapenemases. Deste modo, o presente estudo tem como objetivo elucidar os aspectos sobre a caracterização e a relação de plasmídeos que carregam genes do tipo bla ${ }_{\text {СтХ-м-8 }}$ e $m c r-1$ em cepas de $E$. coli isoladas de seres humanos, animais, ambiente aquático e alimentos, no Brasil. Neste estudo são apresentados os resultados da análise plasmidial de 25 cepas de $E$. coli, das quais nove apresentaram o genótipo bla $a_{\mathrm{CTX}-\mathrm{M}-8} / \mathrm{IncI} 1,11$ apresentaram o genótipo $\mathrm{mcr}-1 / \mathrm{IncX} 4$ e cinco

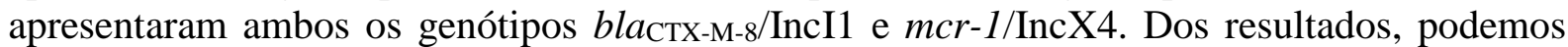

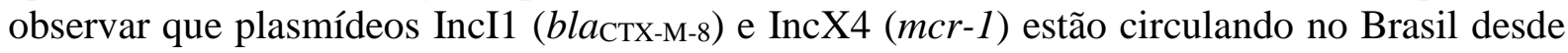
o ano de 2009 entre diferentes clones (STs) de E. coli e em diferentes ambientes e hospedeiros. Os plasmídeos IncI1 foram conjugativos e pertencentes ao ST113, exceto o plasmídeo recuperado de um isolado humano, que foi pertencente ao ST131. Os plasmídeos IncI1 apresentaram sua arquitetura conservada, com a presença de genes de replicação, transferência e estabilidade. A partir do alinhamento, os plasmídeos IncI1 apresentaram 9499\% de similaridade genética entre eles. Dentre os plasmídeos IncX4, independente da fonte de isolamento, todos permaneceram com sua arquitetura altamente conservada. Entretanto, apenas dois plasmídeos (um encontrado em uma cepa de animal e outro encontrado em uma cepa de ambiente aquático) apresentaram uma IS 1294, truncando o gene de mobilização. Na análise comparativa, todos os plasmídeos IncX4 apresentaram similaridade genética de 9599,9\% entre eles. No alinhamento de plasmídeos IncX4 brasileiros contra plasmídeos de outras regiões geográficas, foi observada similaridade genética $>99,9 \%$, o que confirma a estabilidade e conservação desses plasmídeos. Neste estudo foram reportados dados inéditos da primeira identificação do gene $m c r-1$ em diferentes ecossistemas no Brasil, assim como a nova variante $m c r-5.3$. A análise filogenética dos plasmídeos IncI1 e IncX4, destacam que ambos compartilham uma arquitetura conservada, e a evolução é atribuída à aquisição de genes de resistência. Adicionalmente, um novo vetor de disseminação do gene mcr-l no Brasil foi identificado - o plasmídeo IncHI2. Os resultados desse estudo demonstram o grave problema da resistência bacteriana dentro do conceito One-health e que, com o avanço de ferramentas moleculares, a identificação e a resolução desse problema poderá estar cada vez mais próxima de ser elucidada.

Palavras-chave: One-health. Colistina. ESBL. IncI1. IncX4. IncHI2 


\begin{abstract}
FERNANDES, M. R. Ancestral relationship and plasmid pan-resistome of CTX-M-8and MCR-1-producing Escherichia coli in human-animal-environmental interface. 2019. 142f. Thesis (PhD) - Faculdade de Ciências Farmacêuticas, Universidade de São Paulo, São Paulo, 2019.

CTX-M-type extended-spectrum- $\beta$-lactamase (ES $\beta$ L)-producing-Escherichia coli are endemic in Brazil and are prevalent in cases of nosocomial and ambulatory infections. Currently, CTXM-producing strains have been recovered from urban environments, companion/production animals and animal source foods, which indicates a possible route of dissemination in different ecosystems. Recently, in this species, a new gene, called $m c r-1$, has been discovered, conferring transferable resistance to colistin, one of the last effective antibiotics for the treatment of infections caused by ESBL- and carbapenemases -producing bacteria. Thus, the present study aims to elucidate unknown aspects of the pan-resistome and ancestral relationship of plasmids carrying bla $_{\mathrm{CTX}-\mathrm{M}-8}$ and $m c r-1$ genes in strains of $E$. coli isolated from humans, animals, aquatic environment and food, in Brazil. In this study, we present results from the plasmidial analysis of $25 \mathrm{E}$. coli strains, from which nine presented the bla 8/IncI1 genotype, 11 presented the $m c r-1 / \mathrm{IncX} 4$, and five presented both $b l a_{\mathrm{CTX}-\mathrm{M}-8 / \mathrm{IncI} 1 \text { and }}$ $m c r-1 /$ IncX4 genotypes. Among these results, we can observe that IncI1 (bla $a_{\text {CTX-M-8) }}$ and IncX4 ( $m c r-1)$ plasmids are circulating in Brazil since 2009, between different $E$. coli clones (STs) and different hosts and environments. IncI1 plasmids were conjugative and assigned to ST113, with exception of a plasmid recovered from a human isolate, which was assigned to ST131. IncI1 plasmids presented conserved architecture, with the presence of genes of replication, transference, and stability. From the alignment analysis, IncI1 plasmids presented 94-99\% genetic similarity among them. Among the IncX4 plasmids, regardless the isolation source, their architecture remained highly conserved. However, only two plasmids (one detected in an animal's strain and another detected in an aquatic environment's strain) presented an IS 1294, truncating the mobilization gene. In the comparative analysis, all IncX4 plasmids presented 95-99,9\% genetic similarity among them. In the alignment of Brazilian IncX4 plasmids against plasmids from other geographic regions, $>99.9 \%$ genetic similarity was observed, confirming the stability and conservation of these plasmids. In this study, unprecedented data from the first identification of the $m c r-1$ gene in different ecosystems in Brazil, as well as the new variant, $m c r-5.3$. Additionally, it was identified a new dissemination vector of the mcr-1 gene in Brazil - the IncHI2 plasmid. Phylogenetic analysis of IncIland IncX4 plasmids highlight that both share a conserved backbone, and evolution is attributed to the acquisition of clinically relevant antimicrobial resistance genes. The results from this study demonstrate the serious problem of the bacterial resistance within the "One-Health" concept and that, with the advance of molecular tools, identification and resolution of this problem may be increasingly closer to being elucidate.
\end{abstract}

Key-words: One-health. Colistin. ESBL. IncI1. IncX4. IncHI2 


\section{LISTA DE FIGURAS}

Figura 1. Número de mortes estimadas à resistência bacteriana até o ano de 2050

Figura 2. Representação esquemática da disseminação de bactérias resistentes em diferentes ambientes

Figura 3. Transferência horizontal de genes em bactérias 29

Figura 4. Organização estrutural dos principais plasmídeos em Enterobacteriaceae 34

Figura 5. Linha do tempo em relação a emergência de bactérias resistentes à colistina 39

Figura 6. Distribuição intercontinental de plasmídeos que carregam o gene $m c r-1$.................. 40

Figura 7. Esquema de conjugação pelo método em ágar .................................................... 50

Figura 8. Análise comparativa dos plasmídeos IncI1 de diferentes origens ............................. 63

Figura 9. Análise filogenética de plasmídeos IncI1 de diferentes origens ............................... 65

Figura 10. Análise comparativa entre os plasmídeos IncX4 _.................................................

Figura 11. Análise comparativa entre os plasmídeos pICBEC72Hmcr e pICBEC7P............... 68

Figura 12. Análise comparativa dos plasmídeos IncX4 que carregam o gene $m$ crl .................. 70

Figura 13. Esquema representativo dos plasmídeos IncX4 brasileiros e outros de diferentes países

Figura 14. Análise filogenética dos plasmídeos IncX 4 _..................................................... 73

Figura 15. Análise comparativa do plasmídeo pECPB39 com o plasmídeo pKP13a ................ 75

Figura 16. Análise comparativa dos plasmídeos que carregam o gene $m c r-5$.......................... 76 


\section{LISTA DE TABELAS}

Tabela 1. Características gerais das cepas de E. coli produtora de CTX-M-8 e MCR-1

Tabela 2. Sequências de oligonucleotídeos utilizados para detecção dos grupos de incompatibilidade dos plasmídeos 52

Tabela 3. Características fenotípicas e genotípicas das cepas de E. coli produtora de CTX-M-8 56

Tabela 4. Caraterísticas fenotípicas e genotípicas das cepas de E. coli produtora de MCR-1 ......

Tabela 5. Características fenotípicas e genotípicas das cepas de E. coli coprodutoras de CTXM-8 e MCR-1

Tabela 6. Características gerais dos plasmídeos IncI1

Tabela 7. Características gerais dos plasmídeos IncX4 


\section{LISTA DE ABREVIATURAS E SIGLAS}

AMC - Amoxicilina/Ácido Clavulânico

AMI - Amicacina

BLAST - Basic Local Alignment Tool

CC - Complexo Clonal

CEFAP - Centro de Facilidade para a Pesquisa

CGE - Center of Genomic Epidemiology

CFO - Cefoxitina

CIM - Concentração Inibitória Mínima

CIP - Ciprofloxacino

CLSI - Clinical Laboratory Standards Institute

CPM - Cefepima

CRO - Ceftriaxona

CTX - Cefotaxima

CTX-M - Cefotaximase

DNA- Ácido Desoxirribonucléico

dNTP - Desoxirribonucleotídeos Fosfatados

EAEC - Escherichia coli Enteroagregativa

EDTA - Ácido Etilenodiaminotetracético

EIEC - Escherichia coli Enteroinvasora

EPEC - Escherichia coli Enteropatogênica

ExPEC - Escherichia coli Extraintestinal

ETEC - Escherichia coli Enterotoxigênica

EUCAST - Eurepean Committee on Antimicrobil Susceptibility Testing

ESBL - Beta-lactamase de Espectro Estendido

ETP - Ertapenem

GEN - Gentamicina

GENIAL - Genome Investigation and Analysis Laboratory

IPM - Imipenem

ISS - Istituto Superiore di Sanittà

KPC - Klebsiellla pneumoniae carbapenemase

LB - Luria-Bertani

MAUVE - Multiple Genome Alignment

MCR- Resistência à Colistina mobilizável

MR - Multirresistentes

MLST - Multilocus Sequence Typing 
pMLST - Plasmid Multilocus Sequence Typing

NAL - Ácido Nalidíxico

NDM - New Dehli Metalo $\beta$-lactamase

PBRT- PCR- Based Replicon Typing

PCR - Polymerase Chain Reaction

RPM - Rotações por Minuto

SDS - Dodecil Sulfato de Sódio

SNP - Short Tandem Repeats

ST - Sequence Type

SUT - Sulfametoxazol/Trimetoprim

TBE - Tris-Borato-EDTA

TE - Tris-EDTA

TET - Tetracilcina

UPGMA - Unweighted Pair Group Method with Arithimetic Mean 


\section{LISTA DE SÍMBOLOS}

$\beta$ - Beta

${ }^{\circ} \mathrm{C}$ - Graus Celsius

$\mathrm{kb}$ - Quilobase

$\mathrm{kV}$ - Kilovolt

M - Molar

$\mu \mathrm{g}$ - Micrograma

mg - Miligrama

mL - Mililitro

Mm - Milímetro

$\mathrm{N}$ - Normal

ng - Nanograma

$\mathrm{pb}$ - Pares de Base

U - Unidade

V - Volts

$\%$ - Porcentagem

$\geq$ - maior ou igual

>- maior

$<-$ menor 


\section{SUMÁRIO}

1 INTRODUÇÃ

$1.1 \mathrm{O}$ colapso da "era antibiótica" ....................................................................................... 16

1.2 Conceito de saúde única - One-health ......................................................................... 20

1.3 Diversidade genética de Escherichia coli …………………………………………........ 23

1.4 Mobilização de genes de resistência aos antimicrobianos ................................................ 26

1.4.1 Plasmídeos ................................................................................................................ 30

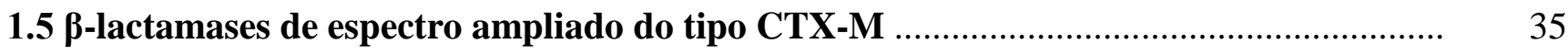

1.6 Resistência à colistina mediada por plasmídeos ……………………………………….... 37

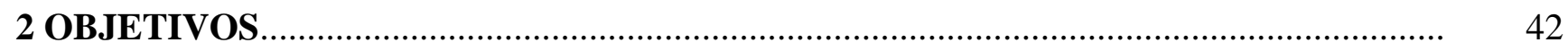

3 MATERIAL E MÉTODOS....................................................................................... 43

3.1 Amostras bacterianas ................................................................................................... 43

3.2 Teste de susceptibilidade aos antimicrobianos ................................................................ 44

3.3 Sequenciamento completo do genoma bacteriano ……………………………………..... $\quad 45$

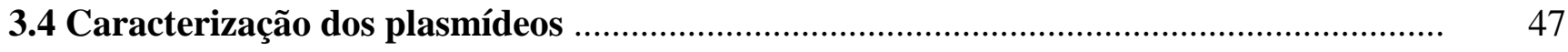

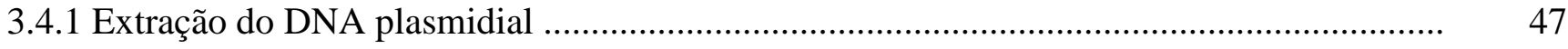

3.4.2 Determinação do tamanho dos plasmídeos ........................................................................ 47

3.4.2.1 Preparo dos plugs ............................................................................................... 47

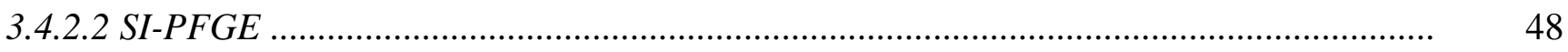

3.4.3 Ensaios de mobilização plasmidial ................................................................................ 48

3.4.3.1 Método de conjugação em caldo ................................................................................. 48

3.4.3.2 Método de conjugação em ágar ................................................................................

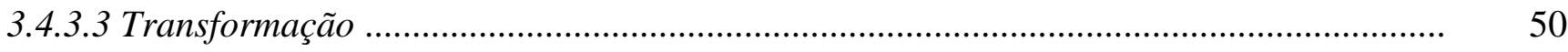

3.4.4 Caracterização dos grupos de incompatibilidade dos plasmídeos.......................................... 51

3.5 Análise do pan-resistoma plasmidial ........................................................................... 53

3.5.1 Montagem e análise dos plasmídeos ............................................................................... 53

3.5.2 Análise filogenética dos plasmídeos .............................................................................. 53

4 RESULTADOS.................................................................................................

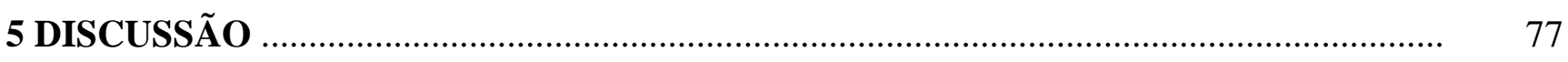

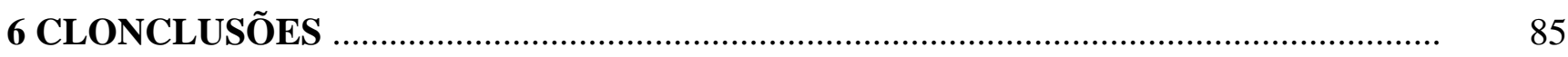

7 REFERÊNCIAS BIBLIOGRÁFICAS ................................................................................ 86

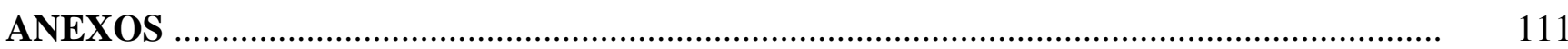




\section{INTRODUÇÃO}

\subsection{0 colapso da "era-antibiótica"}

Os agentes antimicrobianos são substâncias que apresentam a capacidade de inibir o crescimento (microbiostáticos) ou causar a morte (microbicidas) de microrganismos, e são classificados de acordo com a classe à qual pertencem, espectro de atividade e mecanismo de ação. Esses agentes são nomeados como antibióticos quando são produzidos por processos biológicos de microrganismos e agentes quimioterápicos quando são sintetizados em laboratórios (DURAND; RAOULT; DUBOURG, 2019, WRIGHT, 2007).

Os antimicrobianos são considerados a forma mais bem-sucedida no tratamento de doenças infecciosas desenvolvida no século XIX, e talvez em toda a história da medicina. O período da descoberta dos antimicrobianos pode ser dividido em três fases: i) a era dos alcaloides, a qual Joseph Lister, a partir de 1860, começou a usar o fenol para esterilizar materiais cirúrgicos, diminuindo a taxa de morbidade e mortalidade de seus pacientes; ii) era dos compostos sintéticos, quando Paul Erlich, a partir de 1910, introduziu o Salvarsan (composto 606 de arsênico) para tratamento da sífilis; e iii) era dos antibióticos, que iniciou-se em 1928, após a descoberta acidental da penicilina por Alexander Fleming, quando o pesquisador observou a contaminação de suas culturas bacterianas que foram inibidas pelo fungo Penicillium notatum; seguido anos mais tarde por Gerhard Domagk, que em 1935 observou o efeito bacteriostático do Prontosil que se tornou o precursor das sulfonamidas; e em 1940 com a purificação da penicilina para utilização como agente terapêutico em infecções bacterianas, realizada por Howard Florey e Ernst Chain (AMINOV, 2010, DURAND; RAOULT; DUBOURG, 2019, MOHR, 2016, VENTER; HENNINGSEN; BEGG, 2017).

Deste modo, a introdução da penicilina na prática clínica levou a descoberta de outras novas classes de antimicrobianos que são utilizadas até os dias de hoje. Entretanto, em 1945 Fleming advertiu durante sua leitura no Prêmio Nobel que as bactérias eventualmente poderiam evoluir e desenvolver resistência à penicilina e drogas similares. Setenta e quatro anos após seu relato, vivenciamos uma crise global, a qual o uso bem-sucedido de antimicrobianos na clínica tem sido comprometido pelo desenvolvimento de infecções causadas por bactérias multirresistentes (MR), que levam à morte anualmente milhares de pessoas em todo o mundo (DRAENERT et al., 2015). 
Atualmente, o uso exacerbado de antimicrobianos em países desenvolvidos como os Estados Unidos, onde são utilizados anualmente 3,4 mil toneladas de antimicrobianos em humanos e 8,9 mil toneladas em animais, reflete ainda mais essa catástrofe global (O’NEILL, 2014). Até o ano de 2015, houve uma diminuição de $4 \%$ na utilização de antimicrobianos em países desenvolvidos, em contrapartida o consumo aumentou em $75 \%$ em países subdesenvolvidos. Entre os países mais populosos como a China e Índia o uso de antimicrobianos ainda se encontra abaixo da média global, mas a tendência é desse consumo aumentar. Estima-se que se o uso global de antimicrobianos poderá aumentar ainda mais, atingindo o consumo de 125 bilhões em doses diárias, em comparação com o ano de 2015, no qual foi registrado 42 bilhões de doses (KLEIN et al., 2018).

O período mais importante de descoberta de novos antimicrobianos ocorreu entre os anos de 1950 e 1970. Entretanto, após a década de 70 o número de novas classes de antimicrobianos tem diminuído drasticamente. Para produzir um novo composto, a indústria farmacêutica investe cerca de 10 anos divididos em quatro etapas de pesquisa, o que têm levado à desistência de pesquisa e inovação por parte de muitas indústrias deste setor. Assim, o desenvolvimento da resistência bacteriana aos antimicrobianos tem sido muito mais rápida do que a produção de novos compostos pela indústria, o que poderia ser o início de uma "era pós-antibiótico" (AMINOV, 2010, BROWN; WRIGHT, 2016, JACKSON; CZAPLEWSKI; PIDDOCK, 2018, PETCHIAPPAN; CHATTERJI, 2017, PIDDOCK, 2016).

Segundo a Organização Mundial de Saúde (OMS), caso não sejam tomadas medidas restritivas, estima-se que até o ano de 2050, o número de mortes relacionadas a infecções por bactérias MR aumentará para 10 milhões anualmente, e infecções mais brandas poderão ser fatais (Figura 1) (O’NEILL, 2014). Recentemente, a OMS alertou sobre potencias patógenos que mundialmente desenvolvem altos níveis de resistência, sendo assim o desenvolvimento de novos antimicrobianos é extremamente necessário. Dentre os principais patógenos estão as enterobactérias produtoras de $\beta$-lactamases de espectro estendido (ESBL) e enterobactérias resistentes aos carbapenêmicos (ERC) (WHO, 2017). 
Figura 1. Número de mortes estimadas à resistência bacteriana até o ano de 2050.

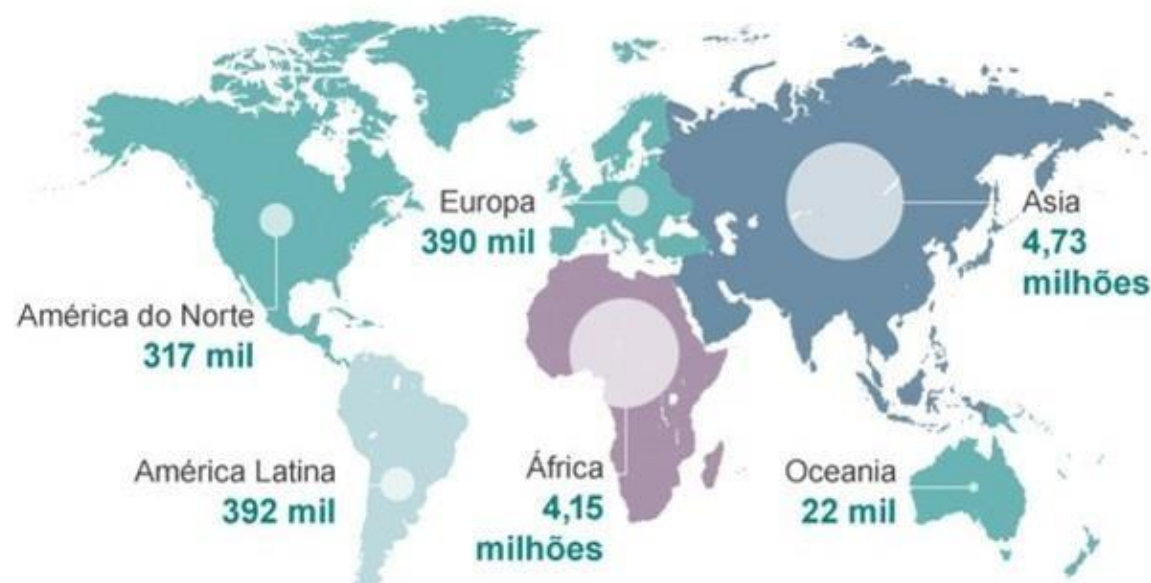

Fonte: Adaptado de O’NEILL, 2014.

O panorama atual da resistência bacteriana tem sido uma somatória de diversos fatores envolvendo: i) a prescrição incorreta de antimicrobianos por médicos, dentistas e veterinários; ii) o uso irracional de antimicrobianos como aditivo zootécnico em animais de produção; iii) a falta de recursos financeiros em hospitais e laboratórios; iii) a carência de programas nacionais de monitoramento; e iv) a falha na formação de profissionais da área da saúde (ASLAM et al., 2018, MARTENS; DEMAIN, 2017, QUIAO et al., 2018).

De acordo com dados do Center for Disease Control and Prevention (CDC), anualmente dois milhões de pessoas contraem infecções por bactérias resistentes e aproximadamente 23.000 vão a óbito nos Estados Unidos. Dentro desses dados o número de casos de infecções por enterobactérias produtoras ESBL e ERC é de 26.000 e 9.000 respectivamente, e a mortalidade é de 1.700 e 600 pacientes a cada ano, respectivamente (CDC, 2018).

Nesse cenário, a prática de políticas públicas, como programas de vigilância, investimento em pesquisas e ações globais são necessárias para alertar e combater a resistência bacteriana. Por essa razão, em 2015 houve a implementação do "Global Antimicrobial Resistance Surveillance System" (GLASS), apoiado pela OMS e por uma rede de centros regionais colaboradores em vigilância de resistência bacteriana. O objetivo da GLASS é apoiar a pesquisa e a vigilância global, otimizar o uso de antimicrobianos, informar a tomada de decisões e conduzir ações globais, nacionais e regionais. Atualmente, 71 países, incluindo o Brasil, estão inscritos nesse programa, e ao participar esses países comprometemse a construir ou reforçar o seu sistema de vigilância de resistência antimicrobiana (GLASS, 
2018).

No Brasil, o atual cenário da resistência antimicrobiana é cada vez mais alarmante nos sistemas de saúde. O aumento no número de casos de infecções relacionadas à assistência à saúde (IRAS) causadas por bactérias MR, tem sido um fator preocupante em pacientes ambulatoriais e hospitalizados (em enfermarias e Unidades de Terapia Intensiva - UTIs) (CAMPANA et al., 2017, BRAUN et al., 2018, MACIEL et al., 2018, MOURA et al., 2017a, OLIVEIRA et al., 2018). De acordo com o boletim epidemiológico elaborado em 2016, a partir de dados obtidos pelas comissões de controle de infecção hospitalar (CCIH) dos hospitais brasileiros com leitos de UTIs, os casos de infecções por bactérias Gram-negativas MR vem crescendo a cada ano, sendo os microrganismos que merecem mais atenção: Acinetobacter spp. e Pseudomonas aeruginosa resistentes aos carbapenêmicos; Klebsiella pneumoniae resistentes as cefalosporinas e carbapenêmicos; e Escherichia coli e Enterobacter spp. resistentes as cefalosporinas (ANVISA, 2016).

Neste contexto, desde 2005 a Agência Nacional de Vigilância Sanitária (ANVISA), juntamente com a Organização Pan-Americana de Saúde (OPAS) e a Coordenação Geral dos Laboratórios de Saúde Pública (CGLAB/SVS/MS) implantou a "Rede Nacional de Monitoramento da Resistência Microbiana em Serviços da Saúde (Rede RM)", com objetivo de detectar, prevenir e controlar a resistência bacteriana em hospitais brasileiros. Assim, a partir dessa iniciativa, outras sub-redes de vigilância foram criadas para fortalecer as ações nacionais e mapear a resistência bacteriana (ANVISA, 2016). Adicionalmente, em 2018 foi elaborado o "Plano de Ação Nacional para Prevenção e Controle da Resistência aos Antimicrobianos do Brasil (PAN-BR)", junto com a OMS, Organização das Nações Unidas para a Alimentação e a Agricultura (FAO) e a Organização Mundial de Saúde Animal (OIE) para serem apresentados ao GLASS. O objetivo do PAN-BR é garantir a prevenção e tratamento de infecções bacterianas, com a utilização de antimicrobianos da forma recomendada em um âmbito multidisciplinar e multisetorial (MINISTÉRIO DA SAÚDE, 2018).

A resistência bacteriana é um evento que não está restrito apenas aos seres humanos, visto que o uso irracional de antimicrobianos na saúde animal também tem sido avaliado. $\mathrm{Na}$ veterinária, os antimicrobianos são utilizados em tratamento de infecções bacterianas, entretanto na maioria dos casos são utilizados profilaticamente em animais saudáveis para prevenir infecções, e também como aditivo alimentar para promover o ganho de massa dos animais de produção (GONZÁLEZ-ZORN; ESCUDERO, 2012). Desta forma, é extremamente necessário implantar programas que tenham o objetivo de: i) monitorar e 
conscientizar os produtores sobre o uso de antimicrobianos nas rações animais; ii) no manejo correto e isolamento dos animais com infecções bacterianas; iii) no descarte correto dos resíduos que contenham antimicrobianos e iv) na educação de médicos veterinários para prescrição criteriosa de antimicrobianos (CISNEROS et al., 2013, COURTENAY et al., 2018, LEE et al., 2015).

Sendo assim, a fim de atenuar problema de infecções causadas por bactérias MR, algumas medidas nacionais têm sido adotadas, como a criação da RDC n ${ }^{\circ} 44$ de 2010 da ANVISA, que proíbe a venda de antimicrobianos sem prescrição médica e recomenda a retenção das receitas nas farmácias. Assim como na veterinária, desde 2016 o uso do sulfato de colistina como aditivo na composição das rações para aves, bovinos e suínos, foi banido pelo Ministério da Agricultura, Pecuária e Abastecimento (MAPA), permitindo apenas o uso para o tratamento de infecções nos animais, devido ao possível impacto na saúde humana (MAPA, 2016).

Infelizmente, a limitação da efetividade dos programas brasileiros do uso irracional de antimicrobianos poderia ser justificado pela vasta faixa territorial brasileira $(8.510 .820,623$ $\mathrm{Km}^{2}$ ), sendo considerado o quinto lugar no mundo em extensão territorial (IBGE, 2019), o que poderia dificultar o monitoramento dos casos de resistência bacteriana em serviços de saúde e no controle do uso exacerbado de antimicrobianos na agricultura e pecuária. A falta de insumos para a realização de testes laboratoriais, o despreparo de profissionais da área da saúde, a falta de informação aos criadores de animais e o mau uso das verbas públicas, também são fatores que levam ao insucesso desses programas.

\subsection{Conceito de saúde única - One-health}

Desde os anos de 1800, os cientistas observavam a similaridade nos processos de doenças entre animais e seres humanos, porém a medicina entre ambos era praticada separadamente até o século XX (EVANS; LEIGHTON, 2014). Nos últimos anos, a preocupação em relacionar a saúde humana e animal tem alcançado um reconhecimento cada vez maior nas comunidades de saúde pública, e essa relação vem sendo estudada como um conceito amplo de saúde única (One-health) (HINCHLIFFE, 2015, MWANGI; DE FIGUEIREDO; CRISCITIELLO, 2016).

O conceito One-health pode ser definido como uma abordagem interdisciplinar entre a saúde humana, animal e o meio ambiente. Sendo assim, a união de médicos, veterinários, ecologistas e autoridades dos governos para monitorar ameaças à saúde pública e para 
entender como as doenças se espalham, tem sido fundamental para a implementação desse conceito (HINCHLIFFE, 2015, LERNER, BERG, 2015, JOHNSON; HANSEN; BI, 2018, WHO, 2017).

Diante disso, em 2010, diferentes agências como a OIE, OMS e a FAO se uniram para o desenvolvimento de estratégias visando a redução da disseminação de doenças infecciosas (e também bactérias MR) resultantes da interface entre humanos, animais, e diferentes ecossistemas (FAO, OIE, WHO, 2017).

Embora o termo One-Health seja relativamente novo, historicamente este conceito já foi reportado nos escritos do médico Hipócrates (460-367 a.C.) "On Airs, Waters and Places", no qual ele correlacionou a interdependência da saúde pública a um ambiente limpo. Posteriormente, Aristóteles (384-322 a.C.) introduziu o conceito de medicina comparativa em seus estudos sobre as características comuns entre diferentes espécies, incluindo os seres humanos e outros mamíferos, em diversos livros de sua série "Historia Animalium". Com o passar dos anos, diversos pesquisadores estudaram e relataram a relação da saúde dos seres humanos e animais, sendo que entre os anos de 1821-1902 o médico alemão Rudolf Virchow criou o termo "zoonose" para indicar que uma doença infecciosa poderia ser transmitida entre animais e seres humanos (ASOKAN, 2015, EVANS; LEIGHTON, 2014, LERNER, BERG, 2015).

O termo zoonose é adotado para definir a transmissão de patógenos (inclusive bactérias MR) entre animais e seres humanos, entretanto através do uso de ferramentas moleculares foi mostrado que humanos também podem ser responsáveis por transmitir patógenos aos animais em um evento zoonótico reverso, chamado de zooantroponose (HUBÁLEK, 2003, MESSENGER et al., 2014, SELLERA et al., 2019). Esses conceitos reforçam ainda mais a importância da comunicação entre médicos e veterinários, visando a prevenção e o tratamento de doenças.

Animais e seres humanos estão continuamente em contato com antimicrobianos, seja pela exposição ao composto durante um tratamento ou pela ingestão de alimentos que podem conter resíduos de antimicrobianos, o que contribui diretamente para a seleção e a presença de bactérias resistentes em sua microbiota (RICHTER et al., 2015; VAN BOECKEL et al., 2015). A colonização por bactérias MR também pode estar associada a: internação prolongada, lesões cutâneas crônicas, procedimentos invasivos, contato com pacientes hospitalizados, assim como o meio ambiente em que vivem (Figura 2) (FERNANDES et al., 2018a, FERNANDES et al., 2018b, MELO et al., 2018; SILVA et al., 2018a, SILVA et al., 2018b) 
Figura 2. Representação esquemática da disseminação de bactérias resistentes em diferentes ambientes

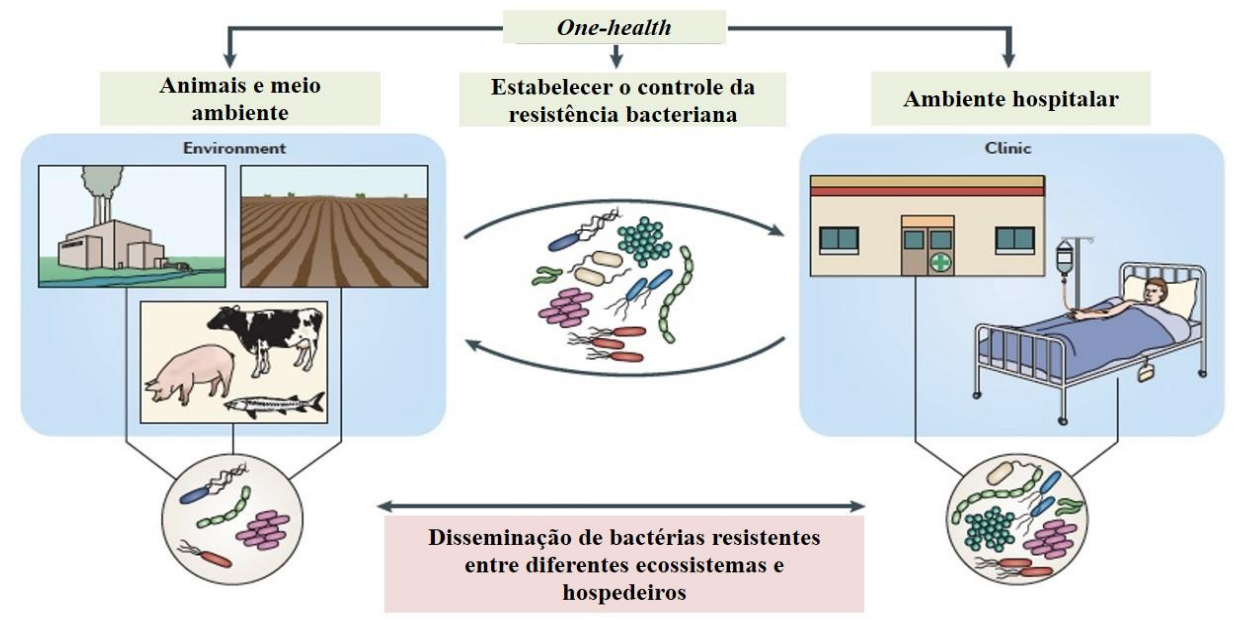

Legenda: A disseminação de bactérias multirresistentes entre diferentes ambientes é considerado um problema global de saúde pública. A alta exposição de animais de produção aos antimicrobianos, assim como o uso irracional em pacientes, tornam-se responsáveis pelo insucesso da terapia antimicrobiana. Fonte: Adaptado de BERENDONK et al. (2015).

Diversas atividades antropogênicas contaminam o meio ambiente, como o descarte impróprio de esgoto industrial e/ou hospitalar, que podem carrear resíduos de antimicrobianos e a descarga de bactérias MR, criando grandes reservas ambientais de resistência e contribuindo com a modificação de diversos ecossistemas (CHENG et al., 2015; DROPA et al., 2016, NASCIMENTO et al., 2017, ROCA et al., 2015). O ambiente doméstico também pode se tornar um veículo para transmissão de bactérias MR, onde pacientes hospitalizados ao retornarem as suas casas podem disseminar genes de resistência entre seus familiares, animais de companhia e em áreas comuns da residência (FERNANDES et al., 2018c, GOTTESMAN et al., 2008).

Embora a exposição a ambientes poluídos constitua um fator de risco para os seres humanos adquirirem bactérias MR, isso também pode ter implicações aos animais silvestres. Animais capturados que recebem tratamento com antimicrobianos e são novamente reintroduzidos na natureza, assim como o comércio ilegal desses animais para serem “domesticados”, representa uma ameaça à saúde pública e na manutenção do ecossistema. Assim, a resistência antimicrobiana também deve ser vista como um problema ecológico, uma vez que esses animais colonizados também podem disseminar bactérias MR, inclusive aos 
ambientes de baixa exposição antropogênica(CARROL et al., 2015, FUENTES-CASTILLO et al., 2019, GOLDBERG et al., 2019, MARTINS et al., 2018, NARCISO et al., 2017, SELLERA, 2019).

Além disso, os antimicrobianos comumente usados na agricultura, pecuária e na aquacultura são misturados com os alimentos ou dissolvidos diretamente na água, e essa prática tem sido refletida na presença de genes de resistência aos antimicrobianos nesses animais. No entanto, peixes e frutos do mar não são capazes de metabolizar completamente os antimicrobianos, sendo esses compostos devolvidos aos ambientes aquáticos em que vivem (DE ARAUJO et a., 2016, MONTE et al., 2019, SELLERA et al., 2018a, SELLERA et al., 2018b, SACRAMENTO et al., 2018, SACRAMENTO et., 2019).

Desta maneira, a união interdisciplinar no conceito One-health se torna importante para detectar, responder e prevenir: surtos de zoonoses e zooantroponoses, problemas com a segurança alimentar e contaminações ambientais por resíduos domésticos, hospitalares e industriais. Um maior investimento na pesquisa de vacinas e testes diagnósticos para infecções específicas, assim como o criar legislações proibindo o uso dos mesmos antimicrobianos em animais e seres humanos, são ações que poderiam contribuir para diminuição da disseminação desses patógenos.

\subsection{Diversidade genética de Escherichia coli}

Escherichia coli é um bacilo Gram-negativo que pertence à família Enterobacteriaceae, sendo considerada a principal bactéria facultativa presente na microbiota intestinal de seres humanos e animais homeotérmicos. A ocorrência de E. coli em alimentos e no ambiente, particularmente em sistemas aquáticos, é uma preocupação pois essa bactéria é considerada um indicador universal de contaminação fecal (BAIN et al., 2014, KOSTYLA et al., 2015, VILA et al., 2016).

A maioria das linhagens de E. coli não são consideradas patogênicas, entretanto, algumas cepas adquiriram fatores de virulência, que proporcionaram algumas combinações genéticas bem-sucedidas, conferindo a capacidade de causar uma ampla variedade de infecções. É um microrganismo bastante diversificado em seus aspectos genéticos, fisiológicos, ecológicos e patogênicos, apresentado, portanto, uma ampla diversidade clonal (ALTERI; MOBLEY, 2012, MAKVANA; KRILOV, 2015, SAROWSKA et al., 2019, VILA et al., 2016). Esta versatilidade tem levado a diferenciar grupos comensais e patogênicos [intestinais (E. coli diarreiogênica - DEC) e extraintestinais (E. coli extraintestinal - ExPEC)] 
(ARENAS-HERNÁNDEZ; MARTÍNEZ-LAGUNA; TORRES, 2012, DALE; WOODFORD, 2015, CROXEN; FINLAY, 2010).

E. coli patogênicas intestinais podem ser divididas em seis patotipos de acordo com seus fatores de virulência e pelos mecanismos que ocasionam a diarreia em humanos e animais, sendo eles: E. coli enteropatogênica (EPEC), E. coli enterotoxigênica (ETEC), E. coli enteroinvasora (EIEC), E. coli produtora de toxina Shiga (STEC), E. coli enteroagregativa (EAEC), E. coli que adere difusamente às células epiteliais (DAEC). Sabe-se que alguns desses patotipos incluem algumas variações, como no caso de E. coli enterohemorrágica (EHEC) que são uma subcategoria de STEC, e as variações EAEC e EPEC que foram subdivididas em típicas e atípicas (CROXEN et al., 2013, GOMES et al., 2016, JUBELIN et al., 2018, KAPER; NATARO; MOBLEY, 2004). Outro grupo de E. coli, associado as infecções extraintestinais, são agentes etiológicos de infecções nosocomiais e comunitárias como: UPEC (E. coli uropatogênica responsável por infecções do trato urinário); ExPEC (associadas as infecções urinárias e em sepses); e MNEC (E. coli causadora de meningite neonatal) (BARDAK-OZCEM; SIPAHI, 2014, JOHNSON; RUSSO, 2018).

Em aves linhagens de E. coli patogênica (APEC) causam uma ampla diversidade de doenças como colibacilose, síndrome da cara inchada e enterites, sendo responsáveis por grandes perdas econômica na produção avícola (AL-KANDARI; WOODWARD, 2019).

Uma forma simples de classificação filogenética de $E$. coli, tem proposto a diferenciação de linhagens de baixa e alta virulência, onde os grupos filogenéticos denominados A e B1 são associados com microbiota comensal e os grupos B2 e D são associados com ExPEC. A identificação desses filogrupos é baseada na presença ou ausência dos genes chuA, yjaA e o fragmento genético TspE4.C2 (CLERMONT; BONACORSI; BINGEN, 2000). Esta classificação filogenética foi reescrita por Clermont e colaboradores (2013), onde foi incorporada a identificação dos genes $\operatorname{arpa}$ e $\operatorname{trp} A$, agrupando agora sete grupos filogenéticos: A, B1, B2, C, D, E, e F, sendo que as linhagens capazes de produzir infecções se relacionam aos grupos B2, D, E e F. Por outro lado, linhagens comensais pertencem aos grupos A, B1 e C (CLERMONT; GORDON; DENAMUR, 2015)

Diferentes metodologias de tipagem molecular para discriminação de clones entre os isolados de E. coli são utilizadas, como o Pulsed Field Gel Electrophoresis (PFGE) e Multilocus Sequence Typing (MLST). A técnica de PFGE é baseada na fragmentação do DNA cromossômico bacteriano por enzimas de restrição, o qual é submetido à eletroforese de campo pulsado, gerando fragmentos que são analisados e comparados (SALIPANTE et al., 2015). No MLST a metodologia é baseada no sequenciamento de genes conservados 
(housekeeping) entre espécies bacterianas. A combinação de alelos gera um sequence type (ST) que pode ser agrupado em complexos clonais (CCs) pela similaridade com um mesmo ancestral comum (MAIDEN et al., 2013).

Atualmente, diversos clones de E. coli são classificados como pandêmicos, sendo eles: ST131, ST69, ST95, ST73 ST393 (GHOSH et al., 2017, NOVAIS et al., 2013, RILEY, 2014). A disseminação global desses clones, que são considerados de alto risco, está diretamente relacionada aos seus fatores de virulência e genes de resistência aos antimicrobianos, os quais conferem vantagens adaptativas no que se refere à colonização do hospedeiro e à competitividade com outras bactérias, respectivamente. Esses clones são frequentemente associados a infecções do trato urinário e infecções de corrente sanguínea em ambientes comunitários e hospitalares, sendo também descritos em animais, alimentos e ambientes aquáticos (NICOLAS-CHANOINE; BERTRAND; MADEC, 2014). Entretanto, outras linhagens como ST10, ST38, ST127, ST405, ST410 e ST648, representam, mais recentemente, os clones emergentes e com potencial zoonótico, e já foram descritos em amostras de múltiplas origens (FERNANDES et al., 2018a, IZDEBSKI et al., 2013, DANTAS-PALMEIRA et a., 2018, OLIVEIRA et al., 2018, SCHAUFLER et al., 2019).

Recentemente, com o sucesso das técnicas de sequenciamento do genoma completo (Whole Genome Sequence - WGS), é possível gerar dados mais precisos e uma variedade de métodos está sendo implementada para análises de relação clonal entre isolados bacterianos, como por exemplo: i) a construção de filogenias com polimorfismo de nucleotídeo único (Single Nucleotide Polimorfism-SNPs) utilizando genomas de referência; ii) comparação do genoma em análise com um genoma de referência; iii) análise baseada em um conjunto maior de genes compartilhados por um grupo de cepas relacionadas (Core genomeMLST cgMLST), iv), e até em esquemas de genomas totais (Whole genome-MLST wgMLST), baseado no conceito do MLST de variação alélica, o que significa que as recombinações e deleções ou inserções de múltiplas posições são contadas como eventos evolutivos únicos, sendo mais discriminativos (CHATTAWAY et al., 2017, FEIJÃO et al., 2018).

A resistência antimicrobiana em infecções causadas por E. coli é considerada um problema global de saúde pública em seres humanos e animais. Além disso, a presença de $E$. coli MR em sistemas aquáticos devido ao descarte inapropriado de esgoto hospitalar e domiciliar em afluentes de rios e oceanos, tem sido amplamente descrita na literatura, e tem contribuindo para disseminação de genes de resistência de importância na medicina humana (CTX-M, KPC-2, NDM-1 e MCR-1) nesses ambientes (DROPA et al., 2016, FERNANDES 
et al., 2017, NASCIMENTO et al.,2017, SACRAMENTO et al., 2019).

Diversos mecanismos de resistência aos antimicrobianos podem ser identificados em E. coli, particularmente, a resistência às quinolonas mediada por plasmídeos (PMQR) e a produção de ESBLs do tipo CTX-M que tem emergido drasticamente em diversos países. No entanto, a propagação de genes de resistência nessas estirpes tem sido associada à presença de clones de alto risco, como por exemplo, o clone pandêmico B2-O25:H4-ST131, responsável pela disseminação de bla $a_{\mathrm{CTX}-\mathrm{M}-15}$ em diferentes hospedeiros e ecossistemas (KAWAMURA et al., 2018, PAITAN, 2018, VILA et al., 2016).

Atualmente, o cenário de resistência aos antimicrobianos em E. coli tem se tornado ainda mais preocupante, devido ao aparecimento de linhagens produtoras de carbapenemases, e mais recentemente, a resistência às polimixinas medida por plasmídeos. Sendo assim, as estirpes de E. coli podem ser consideradas um importante reservatório de genes de resistência a diferentes classes de antimicrobianos, o que vem contribuindo para eventos genéticos de aquisição e disseminação de genes intra e interespécies.

\subsection{Mobilização de genes de resistência aos antimicrobianos}

Os genes são sequências de ácidos nucleicos que, em procariotos, podem estar localizados no cromossomo ou em unidades genômicas extracromossomais. Eles possuem as informações necessárias para a síntese de RNA mensageiro e, consequentemente, de proteínas. Os genes são responsáveis pela transmissão das informações genéticas através da hereditariedade e codificam funções metabólicas, estruturais e seletivas, como por exemplo, os genes de resistência a antimicrobianos (HALL, 2012; PARTRIDGE et al., 2009).

Os genes de resistência são mobilizados entre as bactérias por elementos genéticos móveis, como por exemplo, os integrons, sequências de inserção, transposons e plasmídeos. Esses elementos promovem a mobilidade do DNA intracelular (do cromossomo para um plasmídeo ou entre plasmídeos) e a mobilidade do DNA intercelular (entre membros de uma mesma espécie ou entre espécies de diferentes) (FROST et al., 2005).

Em bactérias Gram-negativas, uma ampla gama de genes de resistência é encontrada como parte de pequenos elementos, chamados de genes cassetes. Eles consistem em um gene sem promotor e com um sítio de recombinação attC. Os genes cassetes não carregam a maquinaria para mobilização e são normalmente encontrados em forma linear integrada em elementos maiores chamados integrons. Os integrons são definidos por três componentes característicos na região conservada 5'CS: i) gene intI que codifica uma enzima tirosina 
recombinase sítio-específica, responsável pela integração, bem como excisão de cassetes gênicos; ii) sítio de recombinação attI; e iii) promotor incorporado no gene intI, orientado para o ponto de integração, que regula a expressão dos genes cassetes. Na região conservada 3'CS estão localizados os genes de resistência aos amônios quaternários (qacE $\Delta 1$ ), sulfonamidas (sul 1 ou sul2) e por duas regiões de leituras (operon reading frame- ORF) (DENG et al., 2015, GILLINGS, 2014, PARTRIDGE et al., 2018).

Existem cinco classes de integrons $(1,2,3,4$ e 5) com base na presença de genes integrase distintos, entretanto apenas as três primeiras classes estão implicadas na dispersão de genes de MR em Enterobacteriaceae. Os integrons de classe 1 e 3 são encontrados associados à $\mathrm{Tn} 402$, enquanto que a classe 2 são quase exclusivamente ligados a derivados do Tn7 (ESCUDERO et al., 2015, KAUSHIK et al., 2018, PARTRIDGE et al., 2018). Atualmente, o banco de dados público INTEGRALL (http://integrall.bio.ua.pt/), pode ser utilizado para auxiliar na compilação e organização de sequências disponíveis em integrons (MOURA et al., 2009).

As sequências de inserção (insertion sequence - IS) são segmentos curtos de DNA variando de 400 a $3.000 \mathrm{pb}$, que carregam genes de transposase (tnp) e apresentam repetições invertidas (inverted repeates- IRs) em suas extremidades (PARTRIDGE et al., 2018, VANDECRAEN et al., 2017). Tradicionalmente, a presença de duas IS pode mover genes de resistência como parte de um transposon composto, como por exemplo Tn10 (IS10) que podem codificar genes de resistência a diferentes classes de antimicrobianos. Aproximadamente existem mais de 4500 IS pertencentes a 29 famílias, identificadas através do ISfinder (https://www-is.biotoul.fr/) que fornece um banco de dados abrangente de IS e inclui ferramentas de pesquisa do BLAST. Inicialmente, sua nomenclatura foi atribuída a números, mas ISfinder agora atribui nomes que incluem um código para as espécies em que o IS foi identificado pela primeira vez (por exemplo, ISAba1 para Acinetobacter baumannii) (VANDECRAEN et al., 2017).

Os elementos da família IS26 (IS6, IS154, IS46, IS140, IS160, IS176 e IS1936), IS257 (IS431) e IS1216 desempenharam um papel fundamental na disseminação de genes de resistência em bactérias Gram-negativas (PARTRIDGE et al., 2018). A ISEcpl (família IS 1380), inicialmente identificada em E. coli, está associado a quatro dos cinco grupos de genes bla $a_{\mathrm{CTX}-\mathrm{M}}$ (grupos CTX-M-1, -M-2, -M-9 e -M-25), além de outros genes como bla $a_{\mathrm{CMY}} \mathrm{e}$ bla $a_{\text {ACC. }}$ Estes elementos estão localizados upstream aos genes, e apresentam pelo menos um promotor a cada gene, sendo que a separação deste promotor resulta na redução da expressão

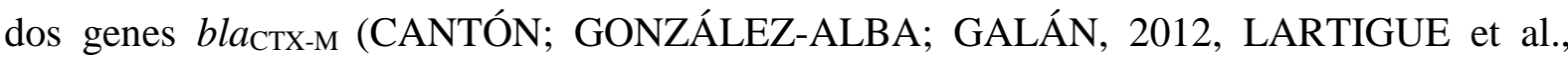


2006). Outras IS apresentam papel importante na disseminação de genes de resistência, como por exemplo, a ISApl1 (família IS30) identificada pela primeira vez em Actinobacillus pleuropneumoniae, e recentemente foi encontrada associada ao gene $m c r-1$ que confere resistência à colistina mediada por plasmídeos (LIU et al., 2015).

Os transposons (Tn) são segmentos de DNA específicos maiores que as IS, e são inseridos repetidamente em um ou mais locais dentro do genoma bacteriano. Apresentam IRs em ambas as extremidades e uma transopasase codificada pelo gene tnpA. O movimento desses elementos é chamado de transposição, um tipo de recombinação sítio-especifica, o qual a transposase reconhece as IRs e desloca o segmento de DNA flanqueado de um sítio para outro. Existem os transposons que não apresentam duas IS em suas extremidades, apresentando apenas uma IR, esses são classificados como transposons não compostos (PARTRIDGE, 2011).

Os transposons das famílias $\operatorname{Tn} 1, \operatorname{Tn} 2$ e Tn3 foram os primeiros a serem identificados em bactérias Gram-negativas. Nesses elementos, tnpA e tnpR são transcritos em direções opostas, e o sitio de resolução (res) fica entre eles. Os genes que codificam as ESBL são encontrados nas frequentemente encontrados nessas famílias de Tn1, Tn2, Tn3 (NICOLAS et al., 2015, PARTRIDGE et al., 2018). O registro do número de transposons pode ser realizado através do banco de dados (http://transposon.lstmed.ac.uk/).

Mecanismos intercelulares de troca horizontal de genes em bactérias incluem: i) transformação, onde ocorre a troca de material genético entre bactérias, sem a necessidade de um vetor. A célula receptora, é dita como competente, pois capta o DNA livre e o incorpora ao seu genoma por recombinação; ii) transdução, sendo mediada por bacteriófagos que transferem o DNA de uma célula à outra; e iii) conjugação, considerado o mecanismo mais eficaz de transferência horizontal de genes, ocorre através do contato entre duas bactérias, sendo mediado por plasmídeos (Figura 3) (FURUYA; LOWY, 2006).

Na conjugação uma bactéria doadora (apresenta o pilus F) reconhece um receptor na bactéria receptora, ocorrendo a formação de um canal entra as duas células bacterianas. $\mathrm{O}$ plasmídeo conjugativo é replicado e transferido à bactéria doadora, tornando-se um transconjugante. Os plasmídeos conjugativos são grandes (>20kb) e possuem sistemas mais complexos que aumentam significativamente o tamanho do seu backbone conservado. As regiões de transferência (tra) dos plasmídeos conjugativos codificam as proteínas MPF (mating pair formation) que funcionam como um sistema secreção do tipo IV especializada (T4SS), bem como proteínas DTR (DNA transfer protein) que processam o DNA plasmídial. As proteínas DTR incluem uma relaxase que corta especificamente a origem da transferência 
(oriT) da fita de DNA que é exportada à célula receptora. Em bactérias Gram-negativas, o T4SS monta um pilus conjugativo, que é um apêndice de superfície filamentosa que medeia as interações com as células receptoras. Na célula doadora, o complexo composto pela proteína DTR e pela oriT excisada (relaxossoma), é ligado ao poro MPF (transferossoma) por uma proteína de acoplamento (T4CP), pertencente à superfamília FtsK/SpoIIIE. Alguns plasmídeos não-conjugativos podem ser transferidos, utilizando o aparato MPF de plasmídeo conjugativo presente na mesma célula. Esses plasmídeos mobilizáveis são menores $(<10 \mathrm{~kb})$ e possuem apenas um subconjunto das funções DTR (geralmente denominadas mob), incluindo oriT e um gene para uma relaxase correspondente (RAMSAY; FIRTH, 2017, SAN MILLAN et al., 2014, SMILLIE et 1., 2010).

Figura 3. Transferência horizontal de genes em bactérias

a. Transformação

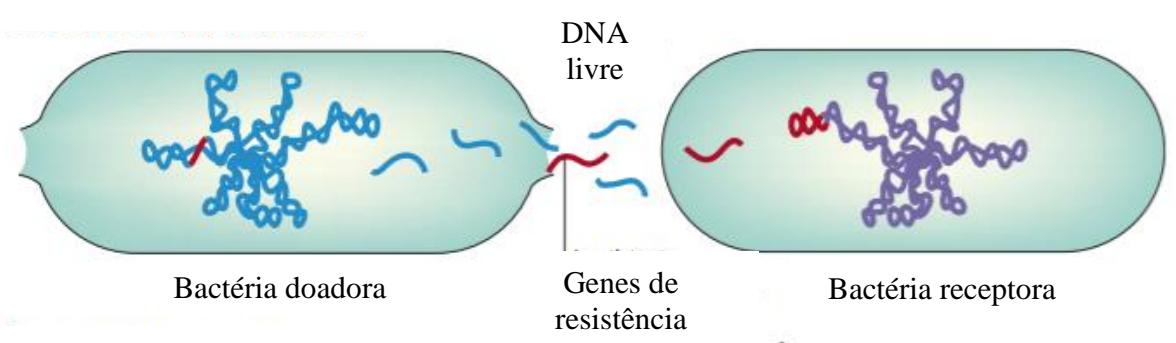

b. Transdução

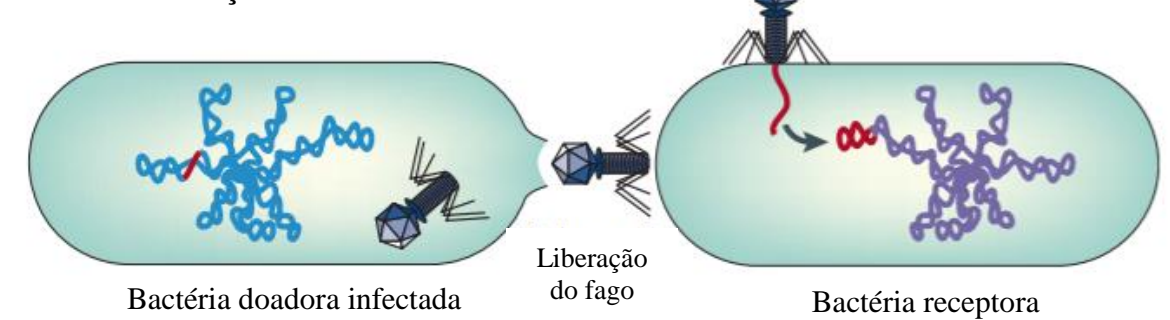

c. Conjugação

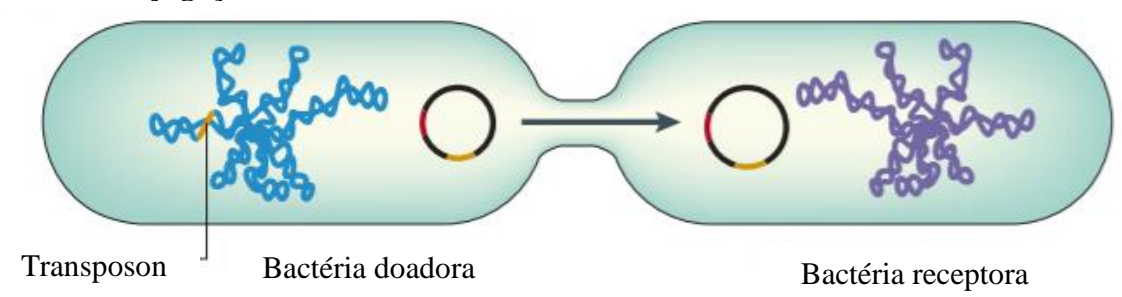

Legenda: a. A transformação ocorre quando o DNA é liberado na lise de um organismo e é absorvido por outro organismo. Genes de resistência aos antimicrobianos podem ser integrados ao cromossomo ou plasmídeo da célula receptora; b. Na transdução, os genes de resistência aos antimicrobianos são transferidos de uma bactéria para outra por meio de bacteriófagos e podem ser integrados no cromossomo da célula receptora; c. A conjugação ocorre pelo contato direto entre duas bactérias, ocorrendo a formação de uma ponte de cruzamento entre as bactérias, e o DNA é transferido, o que pode resultar na aquisição de genes de resistência aos antimicrobianos pela célula receptora. Adaptado de FURUYA; LOWY, 2006 
Os plasmídeos adquirem elementos genéticos móveis (IS e transposons) que são integrados em clusters, conferindo resistência a múltiplas classes de antibióticos. Estes plasmídeos podem conceder uma vantagem seletiva e adaptativa ao hospedeiro bacteriano quando antimicrobianos são administrados (SLATER et al., 2008; FONDI; FANI., 2010).

\subsubsection{Plasmídeos}

Os plasmídeos são moléculas de DNA dupla-fita extracromossomais, circulares ou lineares e que possuem a capacidade de replicação independente (DEL SOLAR et al, 1998). A replicação dos plasmídeos é iniciada em uma região definida, a origem (ori), sendo desencadeada pela ligação de uma proteína de iniciação Rep, codificada pelo gene rep. Assim, os plasmídeos possuem seu próprio início de replicação, mas normalmente exploram a maquinaria de replicação codificada pelo cromossomo da célula hospedeira (como as enzimas helicase, primase e polimerase) para sua própria síntese de DNA (DEL SOLAR et al 1996).

A replicação plasmídial pode ocorrer de duas maneiras: replicação teta $(\Theta)$ e replicação por círculo rolante (THOMAS et al., 2000). A replicação por círculo rolante ocorre com a clivagem de uma das fitas, que se desloca formando duas fitas simples de DNA. Para formação das fitas complementares ocorre a ação da RNA polimerase, que cria um iniciador na região oriV para permitir a replicação do DNA, gerando então o DNA fita dupla circular (DEL SOLAR et al., 1998, KHAN, 2005). A replicação no modo teta se assemelha à replicação circular do cromossomo e é amplamente utilizada. A síntese de DNA é contínua no filamento principal e descontínua, via fragmentos de Okazaki, no filamento atrasado (TOLMASKY, 2013).

A classificação dos plasmídeos pode ser realizada baseando-se em diferentes critérios: (i) número de cópias na célula, (ii) tamanho, (iii) capacidade de transferência e (iv) grupo de incompatibilidade (SHINTANI et al., 2015).

Uma vez replicados, os plasmídeos são distribuídos entre as células filhas quando a divisão ocorre. Para plasmídeos pequenos com alto número de cópias, a herança eficiente por ambas as células filhas pode ser alcançada por segregação aleatória. No entanto, plasmídeos maiores existem em um baixo número de cópias para minimizar a sobrecarga em seus hospedeiros, e possuem módulos funcionais que contribuem para a manutenção do plasmídeo (estabilidade segregacional). Estes incluem resolução (res), partição (par) e sistemas de morte pós-segregacional (sistema toxina-antitoxina -TA) (BAXTER; FUNNELL, 2014, SALJE, 
2010).

Os sistemas de resolução possuem genes que codificam uma recombinase sítioespecífica e um sítio de DNA cognato no qual a recombinase atua. Os sistemas de partição distribuem ativamente cópias de plasmídeos para células filhas e, geralmente, consistem em genes que codificam uma proteína adaptadora de ligação ao DNA que interage tanto com um sítio de DNA quanto com uma proteína "motora" (PARTIDGE et al.,2018). Os sistemas TA codificam uma toxina estável e sua antitoxina lábil neutralizante. A permanência do sistema é assegurada pela diferença de meia-vida da toxina e da antitoxina. Se o sistema TA for perdido, a antitoxina se degrada primeiro e a célula sofre morte mediada por toxinas. Os TAs são classificados, dependendo da natureza e modo de ação da antitoxina, em três tipos: tipos I e III, nos quais as antitoxinas são pequenos RNAs que impedem a tradução da toxina; e sistemas tipo II, nos quais a antitoxina é uma proteína que inibe a toxina através da formação de complexos proteicos (FERNÁNDEZ-GARCÍA et al., 2016, YANG; WALSH, 2017).

A fim de equilibrar as demandas competitivas e o metabolismo no hospedeiro, os plasmídeos controlam seu número de cópias. Os sistemas de controle do número de cópias variam entre os tipos de plasmídeos, mas duas estratégias foram discernidas. A primeira emprega um RNA antisense, constitutivamente expresso e, portanto, proporcional ao número de cópias do plasmídeo, ligando-se ao rep do RNAm complementar para reprimir sua transcrição e / ou tradução; em plasmídeos que usam um iniciador de RNA, como ColE1, a ligação antisense inibe a maturação do primer RNA. No segundo mecanismo, os sítios ori em dois plasmídeos são "bloqueados" por interações entre proteínas Rep e os iterons. Isso modula a atividade do Rep em resposta à concentração de iterons dentro da célula, que é diretamente proporcional ao número de cópias do plasmídeo (DEL SOLAR; ESPINOSA, 2000).

Inicialmente, Datta e Hedges, em 1971, propuseram um método de classificação de plasmídeos baseado na capacidade de dois plasmídeos coexistirem estavelmente na mesma célula, fenômeno conhecido como compatibilidade. Se um plasmídeo não consegue coexistir com outro na mesma célula eles são referidos como pertencentes ao mesmo grupo de incompatibilidade (grupo Inc), devido à sobreposição da maquinaria de replicação do plasmídeo (HARMER; HALL, 2015).

Carattoli e colaboradores (2005) propuseram a detecção de plasmídeos baseada na amplificação de replicons responsáveis pelos principais grupos Inc de plasmídeos que circulam em membros da família Enterobacteriaceae, sendo importante para seguir a evolução e disseminação de plasmídeos emergentes. Atualmente, são conhecidos mais de 30 grupos de incompatibilidade em plasmídeos de Enterobacteriaceae: IncA/C, IncB, IncD, IncF (I -VI), 
IncHI (1,2 e 3), IncI1 (1, 2 e $\gamma)$, IncJ, IncK, IncL/M, IncN, IncO, IncP, IncR, IncS, IncT, IncU, IncV, IncW, IncX (1 até 6) e IncY (CARATTOLI, 2009; COUTURIER et a., 1988, JOHNSON et al., 2012). Os tipos mais detectados de replicons em plasmídeos de resistência em Enterobacteriaceae incluem os grupos de incompatibilidade: F, A/C, L/M, I1, HI2, N e X (DI PILATO et al., 2014; JOHNSON et al., 2012 (Figura 4).

Métodos de estudos para a caracterização epidemiológica de plasmídeos vêm sendo realizados através da técnica de pMLST (Plasmid Multilocus Sequence Typing), tornando-se uma ferramenta útil para monitoramento da ancestralidade desses plasmídeos, pois permite uma discriminação de STs entre áreas geográficas distintas. O pMLST já tem sido aplicado para os grupos de plasmídeos: IncF, IncI1, IncHI1, IncHI2 e IncN (GARCÍA- FERNÁNDEZ et al., 2008; GARCÍA-FERNÁNDEZ et al., 2011; VILLA et al., 2010). Com avanços em genômica, novas ferramentas têm sido desenvolvidas e incorporadas na classificação de plasmídeos como PlasmidFinder 1.3 (https://cge.cbs.dtu.dk/services/PlasmidFinder/) e pMLST1.4 (https://cge.cbs.dtu.dk/services/pMLST/), com intuito de analisa-los com mais profundidade (CARATTOLI et al., 2014).

Plasmídeos epidêmicos são definidos como plasmídeos identificados entre diferentes períodos de tempo, fontes, espécies bacterianas e localização geográficas distintas (CARATTOLI, 2009, MATHERS; PEIRANO; PITOUT, 2015). Dentro dessa categorias, os plasmídeos da família IncI1, IncX4 e IncHI2 são considerados os principais vetores na disseminação de genes de bla al., 2017, MA; FENG; ZONG, 2018, SUN et al., 2017, WONG et al., 2015)

Os plasmídeos IncI1 são plasmídeos conjugativos de baixo número de cópias, que variam em tamanho de 50 a $250 \mathrm{~kb}$, apresentam uma arquitetura conservada e algumas regiões variáveis que codificam funções acessórias, como genes de resistência. A característica deste grupo plasmidial, é a presença de uma região shufflon na extremidade 3' do gene pilV, que permite a recombinação entre sítios específicos (BROWER et al., 2019, CARATTOLI et al., 2018)

São frequentemente associados a disseminação de genes bla $a_{\mathrm{CTX}-\mathrm{M}-1}$, bla $a_{\mathrm{CTX}-\mathrm{M}-15}$ e bla $a_{\mathrm{CMY}-2}$ em E. coli e Salmonella spp (CASTELLANOS et al., 2017, VALCEK et al., 2019, WONG et al., 2015). No Brasil, os plasmídeos IncIl são os principais vetores na

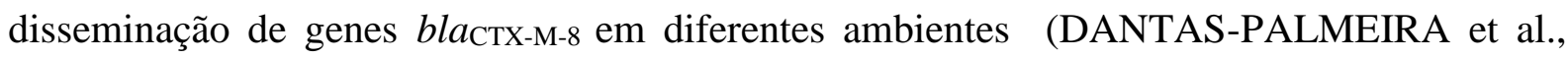
2018, DROPA et al., 2016, CASELLA et al., 2015, FERREIRA et al., 2014, FERNANDES et al 2018b, MELO et al., 2018, SACRAMENTO et al., 2018, SILVA et al., 2018). 
Plasmídeos IncX são amplamente encontrados em espécies de Enterobacteriaceae e são atualmente divididos em seis subtipos (Incx1-IncX6), os quais compartilham grande similaridade genética em sua arquitetura (JOHNSON et al., 2012). Os plasmídeos IncX foram inicialmente detectados em Salmonella spp. na era pré-antibiótica (1917), e atualmente esses plasmídeos continuam sendo vetores de disseminação de genes que conferem resistência aos antibióticos $\beta$-lactâmicos (bla CTX-M $_{\mathrm{C}}$ bla $a_{\mathrm{KPC}}$ e bla $\left.a_{\mathrm{NDM}}\right)$, quinolonas $(q n r B$ e qnrS) e polimixinas ( $m c r-1$ e $m c r-2)$. A arquitetura desse grupo de plasmídeo inclui genes essenciais como: pirbis-par-hns-topB-pilX-actX-taxCA (JOHNSON et al., 2012) os quais são responsáveis pela replicação (pir e bis), síntese e montagem do pilus (pilX), conjugação ( $\operatorname{tax} A C$ ) e funções de manutenção/ estabilidade do plasmídeo (hns e par) (BUSTAMANTE ;IREDELL, 2017)

No Brasil o atual cenário de resistência à colistina, os plasmídeos IncX4 são considerados o principal vetor na disseminação do gene $m c r-1$ em isolados de E. coli em diferentes ecossistemas (FERNANDES et al., AIRES et al., 2017; CONCEIÇÃO-NETO et al., 2017; DALMOLIN et al., 2017, FERNANDES et al., 2016b; FERNANDES et al., 2017, MONTE et al., 2017, ROCHA et al., 2017, SELLERA et al., 2017).

Os plasmídeos conjugativos do grupo incompatibilidade $\mathrm{H}(\mathrm{IncH})$ são divididos em dois grandes grupos, IncHI1 e IncHI2. São plasmídeos de ampla gama de hospedeiros, geralmente com tamanho $>200 \mathrm{~kb}$ e apresentam uma conjugação termosensível devido aos genes que codificam a pili serem expressos à temperatura de 22 e $30^{\circ} \mathrm{C}$, facilitando assim, a disseminação desses plasmídeos no meio ambiente (TAYLOR, 2009). Costumam carregar genes resistência a metais pesados, colicinas e genes de resistência aos antimicrobianos clinicamente significantes, como: bla $a_{\mathrm{CTX}-\mathrm{M}}, o q x A B$, bla $a_{\mathrm{IMP}}$, bla VIM $_{\mathrm{IM}}$ e bla $a_{\mathrm{NDM}}$ e $m c r-1$. Os plasmídeos da família IncHI2 são considerados o terceiro grupo mais frequentemente associado à disseminação mundial do gene $m c r$ - 1 , após os plasmídeos IncI2 e IncX4 (MATAMOROS et al., 2017; GIRLANE et al., 2017; GRAMI et al., 2016; HADJADJ et al., 2017; KIEFFER et al., 2017). 
Figura 4. Organização estrutural dos principais plasmídeos em Enterobacteriaceae
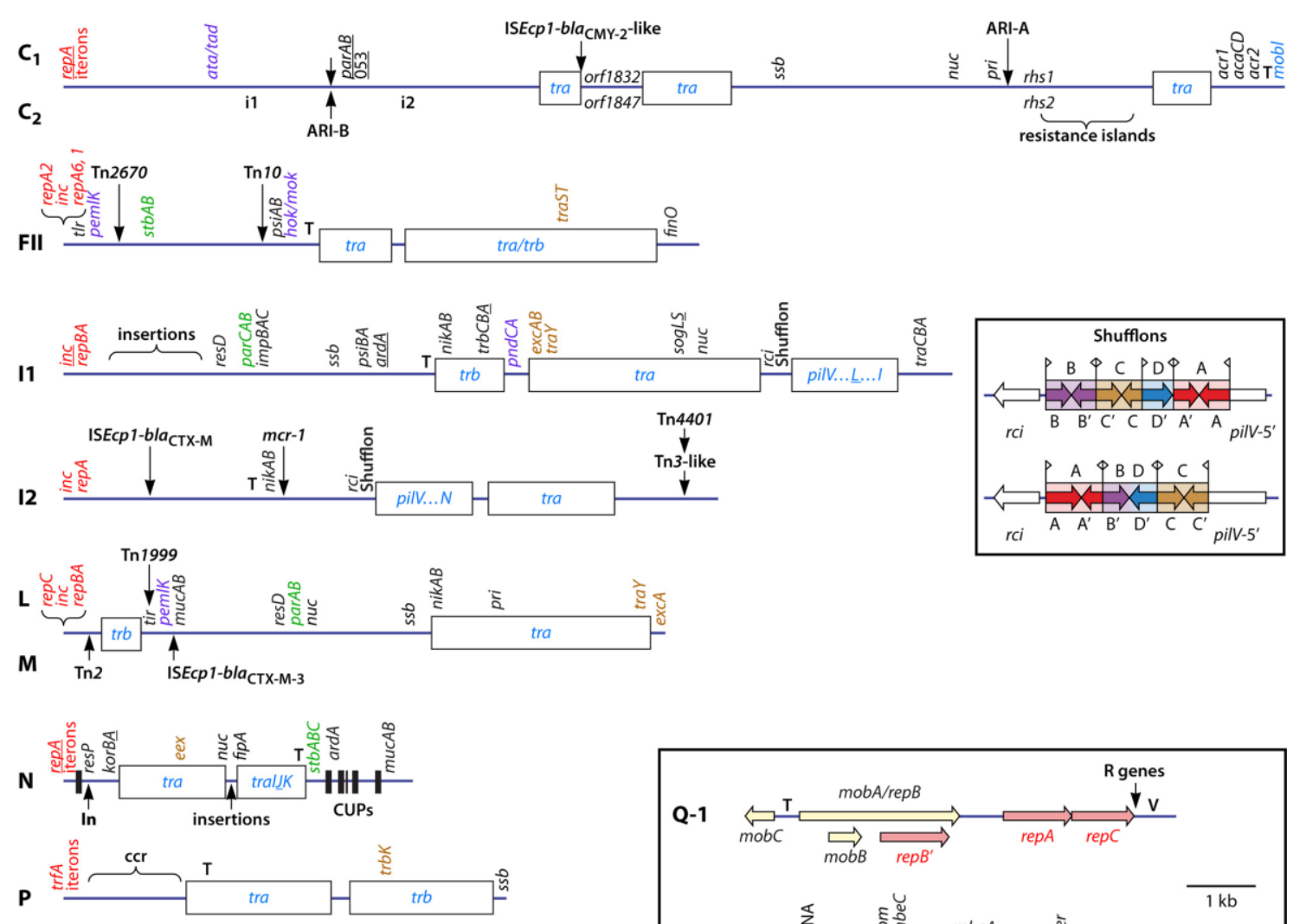

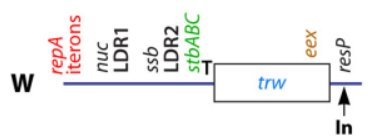
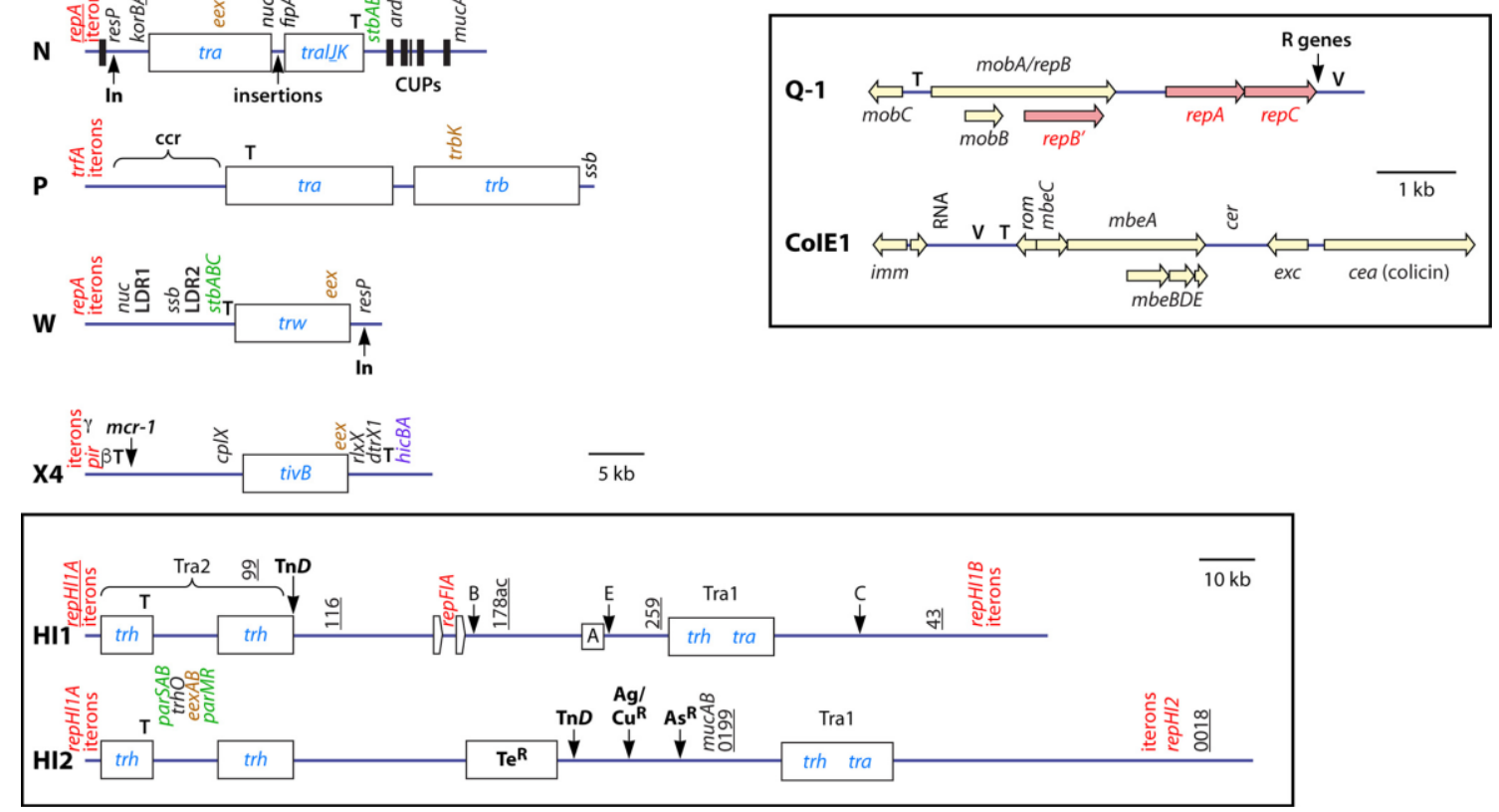

Legenda: Os genes ou regiões selecionadas envolvidas em várias funções são mostrados pelas seguintes cores: vermelho, replicação/oriV; azul, conjugação; verde, manutenção; marrom, exclusão de entrada; e roxo, TA. (PARTIDGE et a., 2018) 
O estudo que envolve a identificação e análise de plasmídeos em um determinado ambiente é denominado de plasmidoma (BLEICHER et al., 2013; DIB et al., 2015). Plasmídeos podem abrigar diversos genes de resistência para mais de uma classe de antimicrobiano. Assim, o sequenciamento e identificação de genótipos de resistência associados aos plasmídeos definem o conceito de resistoma plasmidial (FONDI; FANI, 2010; NESME; SIMONETI, 2015). A análise do resistoma plasmidial pode ser realizada utilizando ferramentas online como ResFinder 2.1 (https://cge.cbs.dtu.dk/services/ResFinder/) para identificação de genes de resistência.

Finalmente, o pan-resistoma plasmidial poderia ser definido como a análise dos genes de resistência às diferentes classes de antimicrobianos, carregados por plasmídeos presentes em bactérias pertencentes a um mesmo gênero, em diferentes ambientes (GILLINGS, 2013).

\section{5 $\beta$-lactamases de espectro ampliado do tipo CTX-M}

As ESBLs são enzimas que hidrolisam os antibióticos $\beta$-lactâmicos: penicilinas, cefalosporinas de amplo espectro e o aztreonam, exceto os antibióticos carbapenêmicos e as cefamicinas. Estas enzimas podem ser inibidas pelo ácido clavulânico, sulbactam e tazobactam (BUSH; JACOBY, 2010). Atualmente, a produção de ESBL é o principal mecanismo de resistência aos antibióticos em espécies de Enterobacteriaceae, especialmente em E. coli, e geralmente são disseminadas por genes presentes em plasmídeos (BUSH; JACOBY, 2010; HARRIS; TAMBYAH; PATERSON, 2015).

A disseminação de ESBLs tem sido reportada em bactérias comensais e patogênicas isoladas de diferentes nichos, tais como: humanos, animais (domésticos, de produção e selvagens) e no meio ambiente. No entanto, hospitais são os principais ambientes onde esses microrganismos podem ser encontrados, devido à pressão seletiva decorrente da antibioticoterapia (ANAGO et al., 2015; BEVAN; JONES; HAWKEY, 2017, DOI; LOVLEVA; BONOMO, 2017; MADEC et al., 2017).

No Brasil, a produção de ESBL em bactérias gram-negativas vem aumentando nos últimos anos, e variantes do tipo TEM, SHV, CTX-M, OXA, PER e GES são frequentemente descritas (CUNHA et al, 2017, GUZMÁN-BLANCO et al., 2014; SILVA; LINCOPAN, 2012; NOGUEIRA et al., 2015; ROCHA; PINTO; BARBOSA, 2016, SAMPAIO; GALES, 2016). Em relação às variantes enzimáticas, há uma alta prevalência de enzimas do tipo TEM e SHV, entretanto nos últimos anos as ESBL do tipo CTX-M (cefotaximases) adquiriram um caráter pandêmico, devido a sua ampla disseminação e número de variantes descritas. As 
enzimas CTX-M foram originadas de genes cromossomais de Kluyvera spp., uma Enterobacteriaceae encontrada em solo (MATHERS et al., 2015; SATO et al., 2014).

A primeira descrição da enzima CTX-M ocorreu em 1989, em um isolado clínico de E. coli, em Munique, Alemanha. As enzimas CTX-M receberam esse nome devido sua resistência à cefotaxima, e a incorporação da letra "M" faz-se referência à cidade de Munique. Ao longo dos anos, o surgimento de novas variantes resultou na inclusão de números para sua diferenciação (BAUERNFEIND; GRIMM; SCHWEIGHART, 1990). Entretanto, uma década após sua descoberta, uma rápida evolução e dispersão destas enzimas já eram observadas pelo mundo (CÁNTON; GONZÁLEZ-ALBA; GALÁN, 2012).

A classificação filogenética das enzimas da família CTX-M é baseada nas sequencias de aminoácidos das enzimas, onde enzimas do mesmo grupo compartilham $>95 \%$ de identidade, e estão divididas em seis grupos: CTX-M-1, CTX-M-2, CTX-M-8, CTX-M-9, CTX-M-25 e KLUC (D’ANDREA et al., 2013).

No Brasil, a produção de enzimas CTX-M tornou-se o mecanismo mais comum de resistência adquirida às cefalosporinas de amplo espectro em bactérias gram-negativas, a partir de amostras clínicas humanas e/ou de animais, e ambientes aquáticos (AIZAWA et al., 2014; ANDRADE et al., 2014; CARVALHO-ASSEF et al., 2014; CASELLA et al., 2015; DROPA et al., 2015; LEIGUE et al., 2015; NOGUEIRA et al., 2015; SILVA et al., 2013). A presença de CTX-M-2 e CTX-M-8 foram descritas em animais de produção no Brasil, evidenciando o alto risco do uso de antimicrobianos em criadouros de aves e ruminantes (BOTELHO et al., 2015; KOGA et al., 2015; PAIVA et al., 2013; TOLLENTINO et al, 2011; AIZAWA et al., 2014). Concomitantemente, a identificação de cepas de E. coli produtoras de CTX-M-2 e CTX-M-8 tem sido reportada em carne de frango comercializado em mercados brasileiros (CASELLA et al., 2015), complementarmente relatos prévios documentaram a presença de ambos os genes em cepas de E. coli isoladas a partir de amostras de carne de frango oriundas da América do Sul exportadas para países europeus (DHANJI et al., 2010, EGERVÄRN et al., 2014; WARREN et al., 2008).

Durante muitos anos as variantes de CTX-M mais identificadas em território brasileiro foram as CTX-M-2, CTX-M-8 e CTX-M-9, porém, mais recentemente, a variante pandêmica CTX-M-15 tem sido amplamente identificada (BUENO et al., 2013; CABRAL et al., 2012; LAHLAOUI et al., 2014; QUEIROZ et al., 2012; QUERESHI; DOI, 2014; SILVA \& LINCOPAN, 2012; SEKI et al., 2013). Sob este contexto, estudos epidemiológicos moleculares têm revelado uma ligação estreita e significativa de genes blacTX-M em 
plasmídeos, pertencentes aos grupos IncF, IncI, IncN, IncHI2, IncL/M e IncX.

Em E. coli, IncF e IncN têm sido associados com a disseminação de diversas variantes

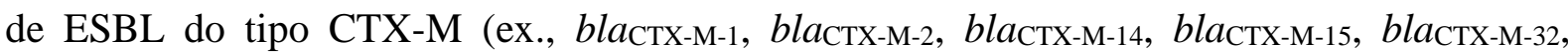

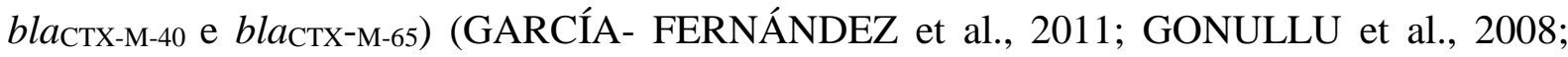
MSHANA et al., 2009; NOVAIS et al., 2006; VILLA et al., 2010).

O uso excessivo de cefalosporinas na medicina humana e veterinária contribuiu com a pandemia das enzimas do tipo CTX-M, resultando na utilização dos carbapenêmicos, antibióticos de "última linha", no tratamento de infecções ocasionadas por bactérias produtoras de ESBL (BUSH; JACOBY, 2010; CARATTOLI, 2013; HARRIS et al., 2015). Entretanto, com a utilização exacerbada desses antibióticos na medicina humana, surgiram as carbapenemases mediadas por plasmídeos, principalmente bla $a_{\mathrm{KPC}}$ e bla $a_{\mathrm{NDM}}$, como mecanismo principal de resistência aos $\beta$-lactâmicos. Atualmente, $K$. pneumoniae produtora de KPC, está disseminada em vários continentes, causando diversos surtos e endemicidade em certas regiões (MATHERS et al., 2015). Mais recentemente, o surgimento de Enterobacteriaceae produtora de NDM também restringe o uso dos carbapenêmicos, tornando as opções para tratamento de bactérias produtoras de carbapenemases limitadas à utilização de polimixinas e tigecilina (NORDMANN; NAAS; POIREL, 2011).

\subsection{Resistência à colistina mediada por plasmídeos}

A polimixina $\mathrm{B}$ e a polimixina $\mathrm{E}$ (colistina) pertencem a um grupo de antibióticos polipeptídios classificados como polimixinas, que foram descobertos em 1949, como produto metabólico da bactéria ambiental Paenibacillus polymyxa subsp. colistinus. São antibióticos catiônicos que apresentam uma alta afinidade por superfícies com cargas negativas, como por exemplo, o lipolissacarídeo (LPS) encontrado em bactérias Gram-negativas. Essa classe de antimicrobiano atua na membrana externa, deslocando o $\mathrm{Ca}^{+}$e $\mathrm{Mg}^{+}$, promovendo o aumento da permeabilidade celular, extravasamento do conteúdo celular e, consequentemente, à morte bacteriana (FALAGAS; RAFAILIDIS; MATTHAIOU 2010).

O espectro de ação das polimixinas é amplo, abrangendo diversas espécies de bacilos Gram-negativos, com exceção de algumas espécies que apresentam resistência intrínseca, dentre elas: Serratia marcescens, Morganella morganii, Proteus spp., Providencia spp., Pseudomonas mallei, Burkholderia spp., Chromobacterium spp., Edwardsiella spp., Brucella spp., Legionella spp., Campylobacter spp. e Vibrio cholerae (FALAGAS; KASIAKOU, 2005; POIREL; JAYOL; NORDMANN, 2017). 
Embora os mecanismos de resistência às polimixinas não tenham sido totalmente elucidados, a aquisição da resistência é atribuída a modificações do LPS devido: (i) a adição de grupos catiônicos ao LPS, reduzindo a carga negativa do LPS e, consequentemente, impedindo ação das polimixinas; (ii) perda do LPS, resultando na perda do alvo de polimixina; e (iii) a hiperexpressão de polissacarídeos capsulares, ocultando sítio de ligação da polimixina. Adicionalmente, modificações nas porinas e superexpressão de sistemas de bomba de efluxo também podem ser observadas (OLAITAN; MORAND; ROLAIN, 2014).

Em 1970 o uso clínico das polimixinas foi suspenso devido a sua alta nefrotoxicidade nos pacientes, sendo substituído pelo uso de aminoglicosideos, quinolonas e $\beta$-lactâmicos. Entretanto, em 2000 com a alta incidência de casos de infecções causadas por bactérias resistentes MDR, as polimixinas foram reintroduzidas como recurso de última escolha terapêutica no tratamento de infecções causadas por bactérias produtoras de carbapenemases (RHOUMA \& LETELLIER, 2017). Infelizmente, em novembro de 2015 foi reportado pela primeira vez, em isolados de $E$. coli provenientes da China, a resistência transferível à colistina codificada pelo gene $m c r$ - 1 , o qual foi localizado em um plasmídeo conjugativo do tipo IncI2, destacando-se como uma nova ameaça para a saúde pública (LIU et al., 2015) (Figura 5). 
Figura 5. Linha do tempo em relação a emergência de bactérias resistentes à colistina

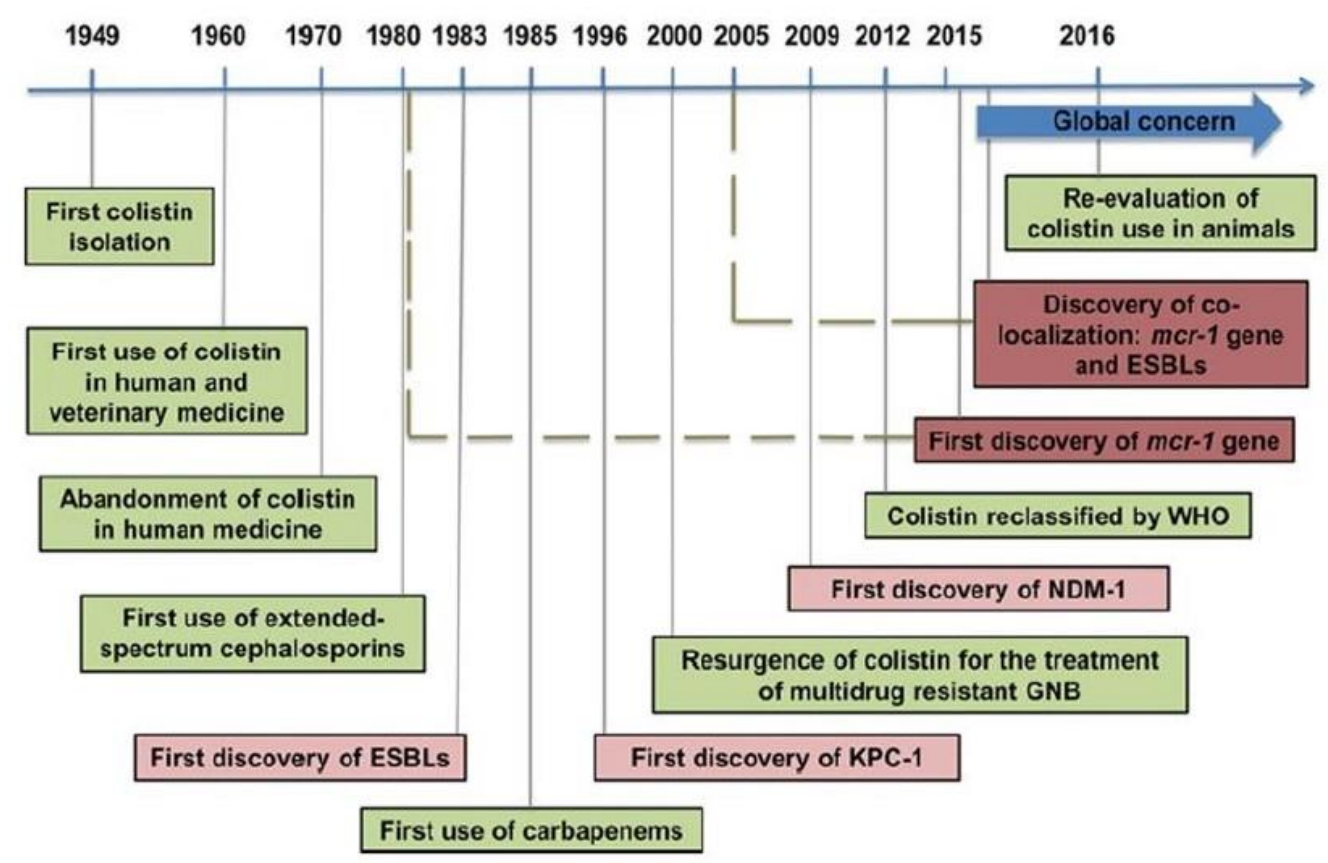

(RHOUMA; LETELLIER, 2017).

Após este primeiro relato, também foi reportado a presença do $m c r-1$ em diversos países da Europa (FALGENHAUER et al., 2016; HAENNI et al., 2016; HASMAN et al., 2015), Ásia (DU et al., 2016; KUO et al., 2016; OLAITAN et al., 2016), África (PERRETEN et al., 2016; POIREL et al., 2016), Américas (FERNANDES et al.,2016a, FERNANDES et al., 2016b; FERNANDES et al., 2017; McGANN et al., 2016; MONTE et al., 2017; MULVEY et al., 2016; RAPPAPORT et al., 2016) e Oceania (ELLEM et al., 2017) (Figura 6). Novas variantes também já foram reportadas como mcr-2 (Bélgica) (XAVIER et al., 2017), mcr-3 (China) (YIN et al. 2017) , mcr-4 (Bélgica, Espanha e Itália) (CARATTOLI et al., 2017), mcr-5 (Alemanha e Brasil) (BOROWIAK et al., 2017, HAMMERL et al., 2018, FERNANDES et al., 2018), mcr-6 (Grã-Bretanha) (ABUOUN et al., 2018), mcr-7 (China) (YANG et al., 2018), mcr-8 (China) (WANG et al., 2018) e mcr-9 (Estados Unidos) (CARROL et al., 2019). 
Figura 6. Distribuição intercontinental de plasmídeos que carregam o gene $m c r-1$

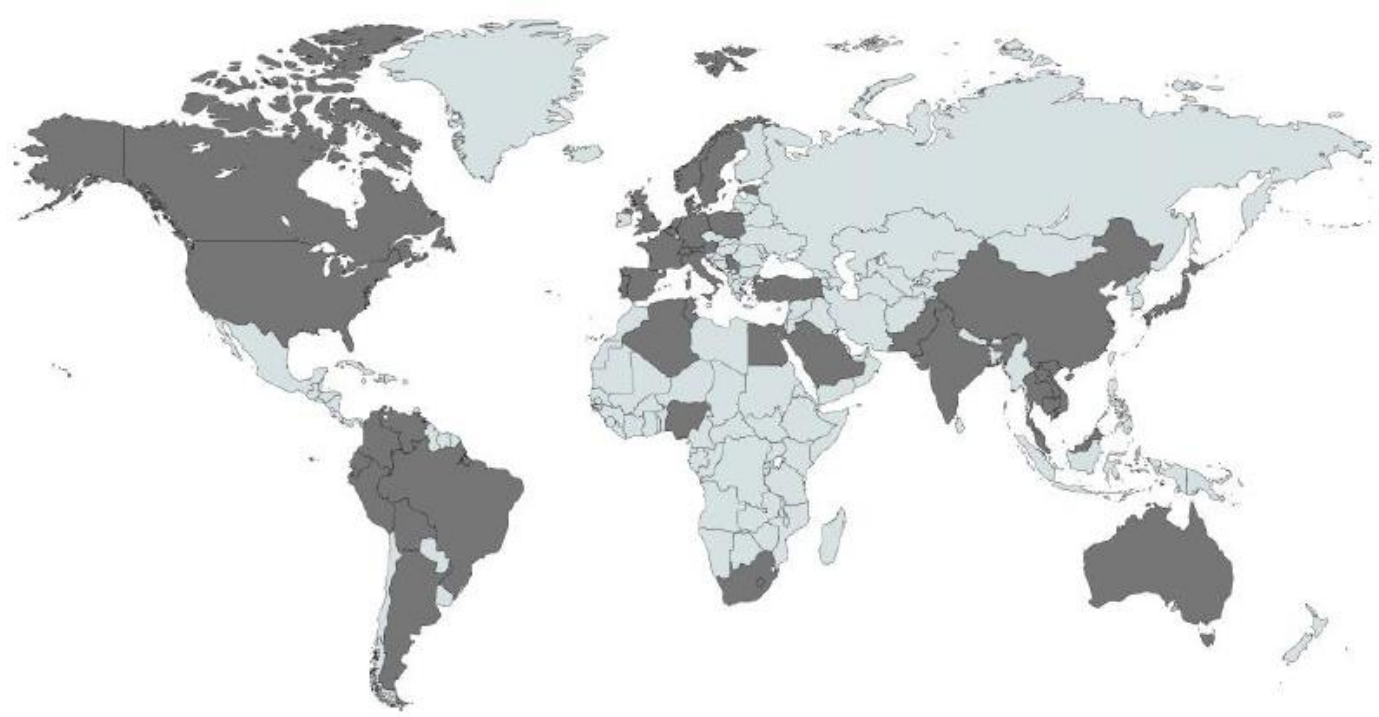

(Arquivo pessoal - banco de dados PubMed em 20 de junho de 2019).

Os plasmídeos que carregam o gene $m c r-1$ têm sido encontrados em diferentes espécies de Enterobacteriaceae, tais como K. pneumoniae, Enterobacter spp., Salmonella enterica, Shigella sonnei, Citrobacter freundii e Kluvyera spp. (SCHWARZ; JOHNSON, 2016; HU et al., 2015; OLAITAN et al., 2016; QUESADA et al., 2016; ZHAO et al., 2016). No entanto, a ocorrência destes plasmídeos tem sido mais predominante nos isolados de $E$. coli, principalmente devido à sua grande versatilidade genética (PERRETEN et al., 2016; POIREL et al., 2016; SELLERA et al., 2017; QUESADA et al., 2016).

Além disso, a ubiquidade desses plasmídeos vem sido observada em diferentes hospedeiros e ambientes como: humanos (infectados e saudáveis), animais de companhia, aves migratórias, répteis exóticos, alimentos de origem animal e vegetais, e ambientes aquáticos, o que reforça a estabilidade desses plasmídeos (SKOV \& MONNET, 2016). Diversos plasmídeos podem atuar como principais vetores para a disseminação do gene mcr-1 em Enterobacteriaceae. Até o presente momento, os plasmídeos encontrados carreando este gene podem ser agrupados em nove tipos, que incluem: IncI2, IncX4, IncHI1, IncHI2, IncF, IncFI, IncFII, IncP e ColE. Curiosamente, a ocorrência de plasmídeos de tipo IncX4 portadores do gene $m c r-1$ foi relatada em 26 países (a maioria da Europa), principalmente entre E. coli, K. pneumoniae e S. entérica (ELLEM et al., 2017; HASMAN et al., 2015; LIU et al., 2016, POIREL et al., 2016; FERNANDES et al., 2016b). 
No Brasil, a ocorrência do gene $m c r$ em plasmídeos Incx4 tem sido identificado em isolados de E. coli em animais de produção (FERNANDES et al., 2016a; LENTZ et al., 2016), infeções em humanos (FERNANDES et al., 2016b, ROCHA et al., 2017), aves migratórias (SELLERA et al., 2017), carne de frango (MONTE et al., 2017) e ambiente marinho (FERNANDES et al., 2017). A coprodução de KPC-2 e MCR-1 em E. coli e K. pneumoniae (AIRES et al., 2017; COICEIÇAO-NETO et al., 2017; DALMOLIN et al., 2017) em pacientes com infecções também foram reportados.

Com avanços em genômica, a epidemiologia molecular de plasmídeos que carregam

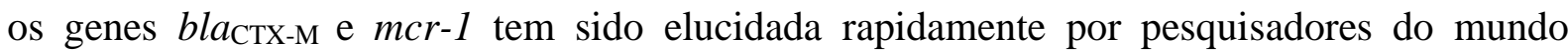
inteiro (FERNANDES et al., 2016b; SNESRUD et al., 2016; SUN et al., 2016; XAVIER et al., 2016; ZURFLUH et al., 2016; WANG et al., 2016). Assim, estudos que visam investigar aspectos relacionados à relação ancestral e pan-resistoma plasmidial podem fornecer uma base científica para monitorar e elucidar a rota epidemiológica e possíveis fontes de aquisição desses genes de resistência. Portanto, as aplicações de ferramentas moleculares e de bioinformática podem ter uma contribuição prática, baseada na identificação da origem e dos veículos de disseminação dos genes de resistência, o que poderia ser aplicado para ter um controle efetivo e estabelecer políticas de vigilância epidemiológica. 


\section{OBJETIVOS}

\subsection{Objetivo geral}

Elucidar os aspectos referentes a relação ancestral e pan-resistoma de plasmídeos que

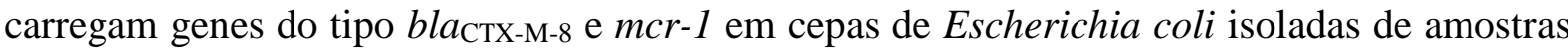
clínicas de seres humanos e animais, alimentos de origem animal e ambientes aquáticos.

\subsection{Objetivos específicos}

1. Caracterizar os plasmídeos que carregam bla $_{\mathrm{CTX}-\mathrm{M}-8}$ e $m c r-1$;

2. Estudar a mobilização dos plasmídeos que carregam genes bla CTX-M-8 $_{\text {e }}$ mcr-1, analisando os resultados em função da origem das cepas;

3. Avaliar e comparar a estrutura dos plasmídeos que carregam os genes bla com outros plasmídeos depositados no banco de dados;

4. Analisar a ancestralidade e a evolução dos plasmídeos que carregam os genes bla $a_{\text {CTX-M-8 }}$ e $m c r 1$. 


\section{MATERIAIS E MÉTODOS}

\subsection{Amostras bacterianas}

Nos últimos anos, nosso grupo de pesquisa tem investigado a resistência aos antimicrobianos em bactérias Gram-negativas produtoras de ESBL e carbapenemases dentro do conceito one-health, em diferentes cidades brasileiras (AIZAWA et al., 2014; CERDEIRA et al., 2017; LEIGUE et al., 2015; FERNANDES et al., 2018a; FERNANDES et al., 2018b; FERNANDES et al., 2018c; LOPES et al., 2017; MELO et al., 2018; MONTE et al., 2017a; MOURA et al., 2017a; MOURA et al., 2017b; NASCIMENTO et al., 2017; OLIVEIRA et al., 2018; SACRAMENTO et al., 2018, SARTORI et al., 2017; SELLERA et al., 2018; SILVA et al., 2018). Nesse cenário, tem sido frequentemente encontrado isolados de E. coli carregando o gene bla $a_{\mathrm{CTX}-\mathrm{M}-8}$ em plasmídeos, entretanto estudos de caracterização e análise filogenética desses plasmídeos ainda são escassos na literatura.

Recentemente, após a descoberta do gene $m c r-1$ (LIU et al., 2016), realizamos a triagem da coleção de cepas resistentes às polimixinas, na qual foi encontrado o gene mcr-1 em amostras de animais de produção (FERNANDES et al., 2016a). Consequente aos achados do gene $m c r$ e suas variantes, desenvolvemos novos estudos epidemiológicos de caracterização de bactérias MR, e detectamos a presença deste gene em isolados de E. coli de diferentes fontes (FERNANDES et al., 2016a; FERNANDES et al., 2016b; FERNANDES et al., 2017; FERNANDES et al., 2018b, MONTE et al., 2017; OLIVEIRA et al., 2018; SELLERA et al., 2017).

Para a caracterização dos plasmídeos de resistência deste estudo, foram avaliadas 25 cepas de E. coli produtoras de CTX-M-8 e MCR-1, isoladas entre os anos de 2009 e 2017, provenientes de seres humanos, animais (domésticos, selvagens e produção), alimentos (carne de frango) e ambientes aquáticos (praias, mangues e esgoto). Sendo assim, foram selecionadas cepas que apresentavam o sequenciamento completo do genoma bacteriano: $\operatorname{bla}_{\mathrm{CTX}-\mathrm{M}-8}(n=$ 9), $\operatorname{mcr}-1 \quad(n=11)$ e coprodutoras dos genes bla Adicionalmente, duas cepas de E. coli produtoras de MCR-1 (50H e CF101) foram estudadas no Istituto Superiore di Sanità, na cidade de Roma, Itália, por apresentarem plasmídeos complexos de serem manuseados. 
Tabela 1. Características gerais dos isolados de E. coli produtora de CTX-M-8 e MCR-1

\begin{tabular}{|c|c|c|c|c|c|}
\hline Id. das cepas & Origem/ fonte & Ano & Localização & Genes de resistência & Referência \\
\hline HEC01 & Humana/ fezes & 2017 & Praia Grande - SP & $b l a_{\text {CTX-M-8 }}$ & Fernandes et al., 2018a \\
\hline FSP 1333/09 & Esgoto tratado/ lodo ativado & 2009 & Barueri- SP & $b l a_{\mathrm{CTX}-\mathrm{M}-8}$ & Dropa et al., 2016 \\
\hline ICBEC7AM & Praia/ água do mar & 2016 & Santos- SP & $b l a_{\mathrm{CTX}-\mathrm{M}-8}$ & Não publicado \\
\hline $56 \mathrm{AC} 1$ & Cachorro /swab retal & 2012 & São Paulo- SP & $b l a_{\mathrm{CTX}-\mathrm{M}-8}$ & Melo et al., 2018 \\
\hline ЕСРВ17 & Gato/ swab retal & 2015 & Patos- PB & $b l a_{\mathrm{CTX}-\mathrm{M}-8}$ & Silva et al., 2018 \\
\hline AJ6 & Cágado / swab cloacal & 2017 & São Luís- MA & $b l a_{\mathrm{CTX}-\mathrm{M}-8}$ & Não publicado \\
\hline $\mathrm{AJ} 20$ & Cágado/ swab cloacal & 2017 & São Luís- MA & $b l a_{\mathrm{CTX}-\mathrm{M}-8}$ & Não publicado \\
\hline $\mathrm{C} 6 \mathrm{O}$ & Bivalve/ ostra & 2016 & Santos- SP & $b l a_{\mathrm{CTX}-\mathrm{M}-8}$ & Não publicado \\
\hline $\mathrm{S} 13.2$ & Crustáceo/ siri & 2017 & São Vicente- SP & $b l a_{\mathrm{CTX}-\mathrm{M}-8}$ & Não publicado \\
\hline $50 \mathrm{H}$ & Humana/ urina & 2016 & Campinas- SP & $m c r-1$ & Oliveira et al., 2018 \\
\hline $51 \mathrm{H}$ & Humana/ urina & 2016 & Campinas- SP & $m c r-1$ & Oliveira et al., 2018 \\
\hline $77 \mathrm{H}$ & Humana/ urina & 2016 & Campinas- SP & $m c r-1$ & Oliveira et al., 2018 \\
\hline $200 \mathrm{H}$ & Humana/ urina & 2017 & Campinas -SP & $m c r-1$ & Oliveira et al., 2018 \\
\hline ICBEC171S & Suíno/ swab retal & 2012 & Minas Gerais & $m c r-1$ & Fernandes et al., 2016a \\
\hline ICBEC146S & Suíno/ swab retal & 2012 & Santa Catarina & $m c r-1$ & Fernandes et al., 2016a \\
\hline CF101 & Carne de frango/ peito & 2016 & São Paulo- SP & $m c r-1$ & Monte et al., 2017 \\
\hline ICBEC7P & Pinguim/ pododermatite & 2013 & Santos- SP & $m c r-1$ & Sellera et al., 2017 \\
\hline ICBEC3AM & Praia/ água do mar & 2016 & Santos- SP & $m c r-1$ & Fernandes et al., 2017 \\
\hline ICBEC13AM & Praia/ água do mar & 2016 & Santos- SP & $m c r-1$ & Fernandes et al., 2017 \\
\hline CF131 & Carne de frango/ peito & 2016 & São Paulo- SP & $m c r-1$ & Monte et al., 2017 \\
\hline ICBEC72H & Humana/ ferida & 2016 & Natal - RN & $b l a_{\mathrm{CTX}-\mathrm{M}-8}, m c r-1$ & Fernandes et al., 2016b \\
\hline $\mathrm{CF} 132$ & Carne de frango / peito & 2016 & São Paulo- SP & $b l a_{\mathrm{CTX}-\mathrm{M}-8,} m c r-1$ & Monte et al., 2017 \\
\hline ICBEC12-3F & Frango/ swab cloacal & 2013 & Paraná & 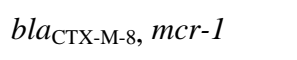 & Fernandes et al., 2016a \\
\hline FP39-2 & Peru / swab cloacal & 2013 & Goiás & $b l a_{\text {CTX-M-8, }} m c r-1$ & Não publicado \\
\hline ЕСРВ39 & Cavalo/ secreção pulmonar & 2012 & Patos- PB & $b l a_{\mathrm{CTX}-\mathrm{M}-8,} m c r-5.3$ & Fernandes et al, 2018 \\
\hline
\end{tabular}

\subsection{Teste de susceptibilidade aos antimicrobianos}

A avaliação do perfil de susceptibilidade aos antimicrobianos foi realizada pelo método qualitativo de disco em difusão- Kirby-Bauer (BAUER et al., 1966). O antibiograma foi realizado de acordo com o documento M02-A12 Clinical and Laboratory Standards Institute (CLSI) (CLSI, 2018). Foram testados os seguintes antimicrobianos de interesse na medicina humana e veterinária: amoxicilina/ácido clavulânico (10-20 $\mu \mathrm{g} / \mathrm{ml})$, aztreonam (30 $\mu \mathrm{g} / \mathrm{ml})$, amicacina $(30 \mu \mathrm{g} / \mathrm{ml})$, ácido nalidíxico, cefepima $(30 \mu \mathrm{g} / \mathrm{ml})$, cefotaxima $(5 \mu \mathrm{g} / \mathrm{ml})$, 
cefoxitina $(30 \mu \mathrm{g} / \mathrm{ml})$, ceftazidima $(10 \mu \mathrm{g} / \mathrm{ml})$, ceftiofur $(30 \mu \mathrm{g} / \mathrm{ml})$, ceftriaxona $(30 \mu \mathrm{g} / \mathrm{ml})$, ciprofloxacino $(5 \mu \mathrm{g} / \mathrm{ml})$, cloranfenicol $(30 \mu \mathrm{g} / \mathrm{ml})$, enrofloxacina $(5 \mu \mathrm{g} / \mathrm{ml})$, ertapenem (10 $\mu \mathrm{g} / \mathrm{ml})$, gentamicina $(10 \mu \mathrm{g} / \mathrm{ml})$, imipenem $(10 \mu \mathrm{g} / \mathrm{ml})$, levofloxacino $(5 \mu \mathrm{g} / \mathrm{ml})$, meropenem $(10 \mu \mathrm{g} / \mathrm{ml})$, sulfametoxazol/trimetoprim $(23,75-1,25 \mu \mathrm{g} / \mathrm{ml})$, da marca Cefar $^{\mathrm{TM}}$.

Após crescimento bacteriano de 18-24 horas, uma colônia de cada isolado foi inoculada em caldo Muller-Hinton e incubada a $37^{\circ} \mathrm{C}$, até atingir a escala 0,5 de McFarland. As suspensões bacterianas foram semeadas em placas de Muller-Hinton, com auxílio de um swab e os discos de antibióticos foram dispostos sob a placa. As placas foram incubadas a $37^{\circ} \mathrm{C}$, por um período de 18-24 horas. De maneira adicional, através da disposição dos discos de cefotaxima, ceftriaxona, cefepime e ceftazidima, ao redor do disco de amoxicilina/ácido clavulânico, pode-se confirmar o fenótipo de ESBL dos isolados. Para interpretação dos resultados, os pontos de corte utilizados para os antibióticos foram estabelecidos de acordo com os critérios do CLSI (CLSI, 2018).

A concentração inibitória mínima (CIM) das cepas de E. coli produtora de CTX-M-8 foi realizada através do teste epsilométrico (E-test), utilizando as fitas com o antibiótico cefotaxima (Biomériux ${ }^{\mathrm{TM}}$ ) em agar Muller Hinton sendo incubadas a $37^{\circ} \mathrm{C}$, por um período de 18-24 horas. A interpretação foi realizada seguindo as recomendações do CLSI (CLSI, 2018). Para a determinação da CIM dos isolados produtores de MCR-1, foi utilizado protocolo descrito pelo European Committee on Antimicrobial Susceptibility testing (EUCAST, 2018), pelo método de microdiluição em caldo (EUCAST, 2018). O antibiótico testado para determinação da CIM foi a colistina, com diluições de 0,125 mg/L - $64 \mathrm{mg} / \mathrm{L}$ (SigmaAldrich ${ }^{\mathrm{TM}}$ ), sendo incubadas a $37^{\circ} \mathrm{C}$, por um período de $18-24$ horas. Os resultados foram interpretados de acordo com EUCAST (EUCAST, 2018).

\subsection{Sequenciamento completo do genoma bacteriano}

O DNA genômico das cepas foi extraído utilizando o kit comercial PureLink ${ }^{\mathrm{TM}}$ Genomic Quick Gel Extraction and PCR Purification (ThermoFisher Scientific ${ }^{\circledR}$ ), sendo realizado conforme as instruções do fabricante. A qualidade e a integridade do DNA obtido foram avaliados por espectrofotometria pelo aparelho DeNovix DS-11 e por eletroforese em gel de agarose. Adicionalmente, a quantificação do DNA foi realizada pelo fluorômetro Qubit ${ }^{\circledR}$ utilizando o kit dsDNA HS (High Sensitivity) conforme as instruções do fabricante.

Inicialmente, foi realizado o preparo de bibliotecas do tipo mated-paired nas cepas: ICBEC72H, ICBEC171S, ICBEC146S e ICBEC12-3F, utilizando o kit Nextera Mated-Paired 
Library Prep Kit (Illumina) de acordo com protocolo do fabricante. O sequenciamento foi realizado na Faculdade de Ciências Farmacêuticas da USP, utilizando a plataforma Illumina MiSeq (300 bp). Nas bibliotecas de preparo mated-paired, são gerados fragmentos de tamanhos maiores $(20 \mathrm{~kb}$ ) diferentemente das bibliotecas do tipo paired-end (até $3 \mathrm{~kb}$ ), o que auxilia na resolução de regiões de repetições e no fechamento completo dos plasmídeos por bioinformática. Entretanto, por se tratar de uma técnica mais laboriosa e com o custo mais elevado, foram escolhidas cepas representativas que apresentavam ambos os genes (bla e $m c r-1)$ para serem utilizadas como "referência" nas montagens dos plasmídeos.

O preparo das bibliotecas tipo paired-end foi realizado utilizando o kit Nextera XT DNA Library Preparation (Illumina) de acordo com protocolo do fabricante. Após o preparo das bibliotecas, o tamanho dos fragmentos foi avaliado pelo método de eletroforese capilar utilizando o sistema Agilent Bioanalyzer DNA 1000, e a quantificação final da biblioteca foi aferida pelo Quibit ${ }^{\circledR}$ utilizando o kit dsDNA HS. O sequenciamento das amostras foi realizado no Centro de Facilidades de apoio à Pesquisa (CEFAP-GENIAL), no Instituto de Ciências Biomédicas da USP (http://cefap.icb.usp.br/core-facilities/genial-genome-investigation-andanalysis-laboratory/), utilizando as plataformas Illumina MiSeq (300 bp) e Illumina NextSeq (150 bp).

Após o sequenciamento, as reads com qualidade PHRED $\geq 20$ foram submetidas à montagem de novo utilizando os programas SPAdes Genome Assembler versão 3.7.0 (Algorithmic Biology Lab), Velvet versão 1.2.10 ou CLC Genomics Workbench versão 12 (Qiagen Bioinformatics), para as sequências geradas. Após as montagens dos genomas, foram avaliados alguns parâmetros de qualidade como: cobertura, conteúdo GC e número de contigs gerados. Para anotação automática do genoma bacteriano, os contigs foram submetidos ao National Center for Biotechnology Information - NCBI (Prokaryotic Genome Annotation Pipeline), e posteriormente à plataforma de dados do Center for Genomic Epidemiology (http://cge.cbs.dtu.dk), onde foram avaliados MLST (Multilocus Sequence Typing MLSTFinder 1.8), genes de resistência (ResFinder 2.1), genes de virulência (VirulenceFinder 1.5), sorotipo de E. coli (SerotypeFinder 2.0) e grupos de incompatibilidade plasmidial (PlasmidFinder). Adicionalmente, análises in silico utilizado os genes: chuA, yjaA e o fragmento de DNA TspE4.C2, foram realizadas para classificação dos filogrupos de E. coli (CLERMONT et al., 2000). 


\subsection{Caracterização dos plasmídeos}

\subsubsection{Extração do DNA plasmidial}

O DNA plasmidial foi extraído pelo método de lise alcalina, como descrito por Birnboim e Doly (1979). A partir do crescimento de uma colônia, as cepas foram inoculadas em $3 \mathrm{~mL}$ de caldo TSB (Tryptic soy broth), sem agitação por 18 horas a $37^{\circ} \mathrm{C}$. Após o crescimento bacteriano, $1 \mathrm{~mL}$ foi centrifugado a $12.000 \mathrm{rpm}$ por 5 minutos e, posteriormente, os sobrenadantes foram descartados e os sedimentos foram ressuspensos em $100 \mu \mathrm{L}$ da solução de lise I (2 mg/ mL de lisozima, 2\% de glicose, $10 \mathrm{mM}$ de EDTA, $25 \mathrm{mM}$ de Tris$\mathrm{HCl}$ pH 8,0 e $1 \mathrm{mg} / \mathrm{mL}$ de RNAse), e incubados em gelo por 30 minutos. Após o tempo de incubação, foram adicionados $200 \mu \mathrm{L}$ da solução II (0,2 N de $\mathrm{NaOH}$ e $1 \%$ de SDS), as suspensões foram homogeneizadas por inversão e mantidas em gelo por 7 minutos. Em seguida, foram adicionados $150 \mu \mathrm{L}$ da solução III para precipitação do DNA cromossômico (3M de acetato de sódio, $\mathrm{pH} 4,8$ ), sendo equitativamente homogeneizadas por inversão, e mantidas em gelo por 1 hora e 30 minutos. Subsequentemente, as suspensões foram centrifugadas a $12.000 \mathrm{rpm}$ por 10 minutos, e os sobrenadantes foram transferidos para novos tubos e $1 \mathrm{~mL}$ de etanol gelado foi adicionado e incubado a $-20^{\circ} \mathrm{C}$ overnight para a precipitação do DNA plasmidial. Após a incubação, as suspensões foram centrifugadas a $12.000 \mathrm{rpm}$ por 10 minutos e os sedimentos foram ressuspensos em $100 \mu \mathrm{L}$ da solução IV (100 mM de acetado de sódio, pH 8,0). Para nova precipitação do DNA plasmidial, foram adicionados $200 \mu \mathrm{L}$ de etanol gelado, seguido por incubação a $-20^{\circ} \mathrm{C}$ overnight. Seguidamente, as suspensões foram centrifugadas a $12.000 \mathrm{rpm}$ por 10 minutos, os sobrenadantes foram descartados e os sedimentos foram secos e ressuspensos em $20 \mu \mathrm{L}$ de água Mili-Q estéril. A qualidade e a concentração do DNA plasmidial obtido foi avaliado por espectrofotometria (DeNovix DS-11).

\subsubsection{Determinação do tamanho dos plasmídeos}

\subsubsection{Preparo dos plugs}

Estes ensaios foram realizados no Laboratório de Microbiologia, da Faculdade de Saúde Pública da Universidade de São Paulo. O protocolo de extração plasmidial foi realizado de acordo com Dropa e colaboradores (2006). 
Os isolados de E. coli foram cultivados overnight em $30 \mathrm{~mL}$ de caldo $\mathrm{LB}$, a $37^{\circ} \mathrm{C}$. Após esse período, os caldos com crescimento bacteriano foram centrifugados a $5.000 \mathrm{rpm}$ por 20 minutos, e as células ressuspensas em $1 \mathrm{~mL}$ de TE (Tris-HCl $10 \mathrm{mM}$, pH 7,5; EDTA $1 \mathrm{mM}, \mathrm{pH} 8,0$ ), sendo transferidas para tubos de 1,5 mL. Novamente, as soluções foram centrifugadas a $12.000 \mathrm{rpm}$ por 5 minutos e as células ressuspensas em $400 \mu \mathrm{L}$ de tampão TE, e desta solução, $80 \mu \mathrm{L}$ foram adicionados a $320 \mu \mathrm{L}$ de agarose de baixo ponto de fusão a $1 \%$. Foram confeccionados os plugs e incubados a $4{ }^{\circ} \mathrm{C}$ por 15 minutos.

Após a solidificação dos plugs, foram tratados em $5 \mathrm{ml}$ de solução de lise (EDTA 50 mM, pH 8,0; (Tris-HCl 50 mM, pH 7,5; SDS 1\%, sarkosyl 1\%, proteinase K 120 $\mu \mathrm{g} / \mathrm{mL}$ ), em tubos cônicos de $15 \mathrm{~mL}$, e incubados a $55^{\circ} \mathrm{C}$ por 2 horas. Após o período de incubação, os plugs foram lavados duas vezes em água ultrapura estéril e quatro vezes em 10 $\mathrm{mL}$ de TE, com intervalos de 15 minutos. Na última lavagem, os plugs foram transferidos para tubos de $1,5 \mathrm{~mL}$ com $1 \mathrm{~mL}$ de TE, e mantidos a $4{ }^{\circ} \mathrm{C}$.

\subsubsection{SI-PFGE}

O protocolo de S1-PFGE foi realizado de acordo com Dropa e colaboradores (2012), sendo adaptada de Barton, Harding e Zuccarelli (1995).

Para a linearização dos plasmídeos, os plugs foram digeridos com $10 \mathrm{U}$ da enzima S1 nuclease (Thermo Fisher ${ }^{\circledR}$ ) por plug em um volume de $350 \mu \mathrm{L}$ do tampão da enzima, por 45 minutos a $37^{\circ} \mathrm{C}$. Após o período de digestão, os plugs foram inseridos em gel de agarose $1 \%$ e submetidos ao PFGE. A corrida de eletroforese foi realizada com solução TBE 0,5X com adição de tiouréia $100 \mathrm{mM}$, com voltagem de $6 \mathrm{~V} / \mathrm{cm}$, com intervalos de pulsos de 1 segundo a 40 segundos, a $14{ }^{\circ} \mathrm{C}$ durante 20 horas.

Após a corrida, o gel foi corado com solução de brometo de etídeo $1 \mu \mathrm{g} / \mathrm{Ml}$ por 1 hora, e o tamanho plasmidial foi avaliado por comparação com o marcador de peso molecular Lambda Ladder PFG Marker.

\subsubsection{Ensaios de mobilização plasmidial}

\subsubsection{Método de conjugação em caldo}

As cepas de E. coli foram submetidas aos ensaios de conjugação para avaliar a capacidade dos plasmídeos que carregavam os genes de resistência bla 
transferidos à outras bactérias. O protocolo de conjugação em caldo empregado foi padronizado neste estudo. Foram testadas como linhagens receptoras as cepas: E. coli C600 resistente à estreptomicina, E. coli $\mathrm{J} 53$ e $\Delta$ C600 resistentes à azida sódica.

As cepas doadoras e receptoras foram inoculadas em caldo Lúria-Bertani (LB) por 6 horas sem agitação a $37^{\circ} \mathrm{C}$, e em seguida foram preparadas suspensões na proporção de 3:1:1 (receptora: doadora: meio LB novo). Após esse período, uma alíquota de $100 \mu \mathrm{L}$ das suspensões foi espalhada com auxílio de alças Drigalsky em placas de ágar MacConkey suplementado com $2 \mu \mathrm{g} / \mathrm{mL}$ de ceftriaxona ou $2 \mu \mathrm{g} / \mathrm{mL}$ de colistina, e $2 \mu \mathrm{mg} / \mathrm{mL}$ de estreptomicina ou $200 \mu \mathrm{g} / \mathrm{mL}$ de ázida sódica para seleção das transconjugantes. Estas suspensões foram incubadas a $37^{\circ} \mathrm{C}$ e testadas em diferentes tempos: $6,8,12$ e 18 horas, sem agitação.

Como controle da conjugação, as linhagens doadoras e receptoras foram semeadas separadamente em seus respectivos meios de seleção. Para confirmar a transferência dos plasmídeos, as possíveis transconjugantes foram avaliadas quanto ao seu fenótipo de resistência pela técnica de difusão em disco e microdiluição. Adicionalmente, a confirmação

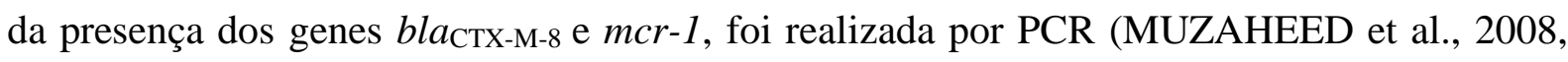
LIU et al., 2016).

\subsubsection{Método de conjugação em ágar}

Os plasmídeos das cepas de E. coli CF101 e 50H estudadas no Istituto Superiore di Sanità foram mobilizados pela técnica em conjugação ágar, padronizada pela Dra Alessandra Caratolli. A linhagem receptora utilizada foi a E. coli CSH26 resistente à rifampicina. As cepas doadoras e receptoras foram cultivadas em meio LB ágar e incubadas a $37^{\circ} \mathrm{C}$ por $18-24$ horas. Após o crescimento bacteriano, com a ajuda da alça bacteriológica foi passado um raspado do crescimento das cepas (doadora e receptora) em LB ágar, formando duas linhas de cruzamento (Figura 7). As placas foram incubadas a 25 e $37^{\circ} \mathrm{C}$ por $18-24$ horas. As cepas transconjugantes foram selecionadas no centro de cruzamento, e foram semeadas em placas de LB suplementadas com rifampicina $(100 \mu \mathrm{g} / \mathrm{mL})$ e colistina $(2 \mu \mathrm{g} / \mathrm{mL})$. Como controle da conjugação, as linhagens doadoras e receptoras foram semeadas separadamente em seus respectivos meios de seleção. A transferência de plasmídeo foi confirmada pelo kit comercial PCR-Based Replicon Type (PBRT) (CARATOLLI et al., 2005), e a presença do gene $m c r-1$ foi confirmada por PCR convencional (LIU et al., 2016). 
Figura 7. Esquema de conjugação pelo método em ágar

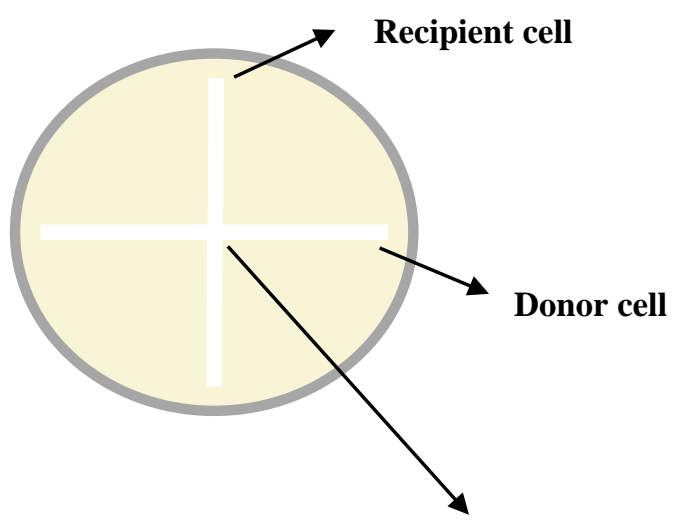

\section{Transconjugants}

Legenda: A cepas doadoras e receptoras são passadas separadamente no ágar LB formando o desenho de uma cruz. Após a incubação, as possíveis cepas transconjugantes são selecionadas no centro da cruz.

Fonte: FERNANDES, 2019.

\subsubsection{Transformação}

Para os plasmídeos que não foram mobilizados pelos ensaios de conjugação, foi utilizado a técnica de transformação por eletroporação. $O$ preparo das células eletrocompetentes foi realizada utilizando-se $3 \mu \mathrm{L}$ da suspensão da linhagem comercial de $E$. coli TOP 10 (Invitrogen ${ }^{\circledR}$ ), que foi inoculada em $25 \mathrm{~mL}$ de caldo $\mathrm{LB}$, sendo incubadas por agitação a $37^{\circ} \mathrm{C}$ por 3 horas até atingir uma densidade ótica de $0,6-0,8$ (DO 600nm). A cultura bacteriana foi resfriada em gelo por 20 minutos e, em seguida, centrifugada a $5500 \mathrm{rpm}$ por 15 minutos a $4^{\circ} \mathrm{C}$. O sedimento foi ressuspenso em $50 \mathrm{~mL}$ de água Mili-Q estéril gelada e este processo foi repetido por mais duas vezes. Os sedimentos foram lavados com glicerol gelado à $10 \%$ e centrifugados a $5500 \mathrm{rpm}$ por 15 minutos a $4{ }^{\circ} \mathrm{C}$, e da mesma forma foram ressuspensos em glicerol gelado a 10\%, e posteriormente alíquotas de $40 \mu \mathrm{L}$ foram distribuídos em microcubos. As células foram mantidas a $-80^{\circ} \mathrm{C}$ até o momento de seu respectivo uso, e foram descongeladas em gelo.

As transformações foram realizadas com a suspensão de $10 \mu \mathrm{L}$ do DNA plasmidial e $45 \mu \mathrm{L}$ das células eletrocompetentes. Estas suspensões foram transferidas para cubetas de eletroporação de $2 \mathrm{~mm}$ e submetidas a uma corrente elétrica de $2 \mathrm{Kv}$ (Eppendorf ${ }^{\circledR}$, Eletroporador 2510). Após eletroporação, as células foram transferidas para $1 \mathrm{~mL}$ de caldo 
LB e incubadas por 2 horas sob agitação. Após esse período, uma alíquota de $100 \mu \mathrm{L}$ das suspensões foi espalhada com auxílio de alças Drigalsky em placas de ágar MacConkey com $2 \mu \mathrm{g} / \mathrm{mL}$ de ceftriaxona ou $2 \mu \mathrm{g} / \mathrm{mL}$ de colistina para seleção dos transformantes e, em seguida, as placas foram incubadas em estufa a $37^{\circ} \mathrm{C}$, por 24 horas.

Para confirmar a transferência dos plasmídeos, as transformantes foram avaliadas quanto ao seu fenótipo de resistência pela técnica de disco difusão e pelo método de

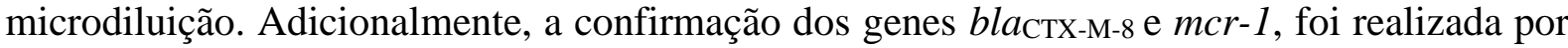
PCR (MUZAHEED et al., 2008, LIU et al., 2016).

3.4.4 Caracterização dos grupos de incompatibilidade dos plasmídeos

Para determinar o grupo de incompatibilidade dos plasmídeos foi utilizado um esquema de tipagem por PCR (PBRT-PCR-Based Replicon Typing) baseado na amplificação de 19 replicons clássicos entre a família Enterobacteriaceae (CARATTOLI et al., 2005; JOHNSON et al., 2012). As reações de PCR foram realizadas a partir do DNA plasmidial das cepas transconjugadas e transformadas, utilizando os oligonucleotídeos apresentados na tabela 2. A amplificação dos genes alvo foi realizada em reações de $25 \mu \mathrm{L}$ contendo aproximadamente $100 \mathrm{ng}$ de DNA plasmidial; tampão de PCR 10X [Tris-HCl (pH 8,4), 50 $\mathrm{mM}$ de $\mathrm{KCl}$ ] (Fermentas ${ }^{\circledR}$, USA), 1,5 mM de MgCl2 (Fermentas ${ }^{\circledR}$ ); $200 \mu \mathrm{M}$ de cada dNTP $\left(\right.$ Fermentas $\left.{ }^{\circledR}\right)$; 25 pmol de cada iniciador e $1 \mathrm{U}$ de Taq DNA polimerase (Fermentas $\left.{ }^{\circledR}\right)$. As condições de amplificação foram as seguintes: 1) desnaturação inicial a $94^{\circ} \mathrm{C}$ por 2 minutos; 2) 30 ciclos de $94^{\circ} \mathrm{C}$ por 30 segundos, anelamento com temperatura específica para cada oligonucleotídeo por 30 segundos e $72{ }^{\circ} \mathrm{C}$ por 1 minuto; 3) extensão final: 1 ciclo de $72{ }^{\circ} \mathrm{C}$ por 5 minutos. Posteriormente, os produtos amplificados foram analisados por eletroforese em gel de agarose à $1 \%$. Foi utilizado um marcador de peso molecular de DNA 100 bp Plus (Thermo Fisher Scientific ${ }^{\circledR}$ ). 
Tabela 2. Sequências de oligonucleotídeos utilizados para detecção dos grupos de incompatibilidade dos plasmídeos (CARATOLLI et al., 2005).

\begin{tabular}{|c|c|c|c|c|}
\hline $\begin{array}{l}\text { Grupo de } \\
\text { Incompatibilidade }\end{array}$ & Sequência oligonucleotídeos $\left(5^{\prime}-3^{\prime}\right)$ & Sítio alvo & $\begin{array}{l}\text { Tamanho } \\
(\mathbf{P b})\end{array}$ & $\begin{array}{l}\text { Temperatura } \\
\left({ }^{\circ} \mathrm{C}\right)\end{array}$ \\
\hline $\mathrm{A} / \mathrm{C}$ & $\begin{array}{l}\text { F: GAGAACCAAAGACAAAGACCTGGA } \\
\text { R: ACGACAAACCTGAATTGCCTCCTT }\end{array}$ & repA & 465 & 60 \\
\hline $\mathrm{B} / \mathrm{O}$ & $\begin{array}{l}\text { F: GCGGTCCGGAAAGCCAGAAAAC } \\
\text { R: TCTGCGTTCCGCCAAGTTCGA }\end{array}$ & RNAI & 159 & 60 \\
\hline FIA & $\begin{array}{l}\text { F: CCATGCTGGTTCTAGAGAAGGTG } \\
\text { R: GTATATCCTTACTGGCTTCCGCAG }\end{array}$ & iterons & 462 & 60 \\
\hline FIB & $\begin{array}{l}\text { F: GGAGTTCTGACACACGATTTTCTG } \\
\text { R: CTCCCGTCGCTTCAGGGCATT }\end{array}$ & repA & 702 & 60 \\
\hline FIC & $\begin{array}{l}\text { F: GTGAACTGGCAGATGAGGAAGG } \\
\text { R: TTCTCCTCGTCGCCAAACTAGAT }\end{array}$ & repA2 & 262 & 60 \\
\hline FIIA $_{S}$ & $\begin{array}{l}\text { F: CTGTCGTAAGCTGATGGC } \\
\text { R: CTCTGCCACAAACTTCAGC }\end{array}$ & repA & 270 & 60 \\
\hline $\mathrm{F}_{\text {repB }}$ & $\begin{array}{l}\text { F: TGATCGTTTAAGGAATTTTG } \\
\text { R: GAAGATCAGTCACACCATCC } \\
\text { F: TGATCGTTTAAGGAATTTTG }\end{array}$ & $\mathrm{RNAI}$ repA & 270 & 52 \\
\hline FrepB & $\begin{array}{l}\text { R: GAAGATCAGTCACACCATCC } \\
\text { R: GAAGATCAGTCACACCATCC }\end{array}$ & $\mathrm{RNAI} /$ repA & 270 & 52 \\
\hline HI1 & $\begin{array}{l}\text { F: GGAGCGATGGATTACTTCAGTAC } \\
\text { R: TGCCGTTTCACCTCGTGAGTA }\end{array}$ & parA-parB & 471 & 60 \\
\hline HI2 & $\begin{array}{l}\text { F: TTTCTCCTGAGTCACCTGTTAACAC } \\
\text { R: GGCTCACTACCGTTGTCATCCT }\end{array}$ & iterons & 644 & 60 \\
\hline I1 & $\begin{array}{l}\text { F: CGAAAGCCGGACGGCAGAA } \\
\text { R: TCGTCGTTCCGCCAAGTTCGT }\end{array}$ & RNAI & 139 & 60 \\
\hline K & $\begin{array}{l}\text { F: GCGGTCCGGAAAGCCAGAAAAC } \\
\text { R: TCTTTCACGAGCCCGCCAAA }\end{array}$ & RNAI & 160 & 60 \\
\hline $\mathrm{L} / \mathrm{M}$ & $\begin{array}{l}\text { F GGATGAAAACTATCAGCATCTGAAG } \\
\text { R: CTGCAGGGGCGATTCTTTAGG }\end{array}$ & repA,B,C & 471 & 60 \\
\hline $\mathrm{N}$ & $\begin{array}{l}\text { F: GTCTAACGAGCTTACCGAAG } \\
\text { R: GTTTCAACTCTGCCAAGTTC }\end{array}$ & repA & 471 & 60 \\
\hline $\mathrm{P}$ & $\begin{array}{l}\text { F: CTATGGCCCTGCAAACGCGCCAGAAA } \\
\text { R: TCACGCGCCAGGGCGCAGCC }\end{array}$ & iterons & 471 & 60 \\
\hline $\mathrm{T}$ & $\begin{array}{l}\text { F: TTGGCCTGTTTGTGCCTAAACCAT } \\
\text { R: CGTTGATTACACTTAGCTTTGGAC }\end{array}$ & repA & 471 & 60 \\
\hline W & $\begin{array}{l}\text { F: CCTAAGAACAACAAAGCCCCCG } \\
\text { R: GGTGCGCGGCATAGAACCGT }\end{array}$ & rep $\mathrm{A}$ & 471 & 60 \\
\hline $\mathrm{X}$ & $\begin{array}{l}\text { F: AACCTTAGAGGCTATTTAAGTTGCTGAT } \\
\text { R: TGAGAGTCAATTTTTATCTCATGTTTTAGC }\end{array}$ & ori $\gamma$ & 471 & 60 \\
\hline $\mathrm{X} 4$ & $\begin{array}{l}\text { F: GTTTTCTCCACGCCCTTGTTCA } \\
\text { R: AGCAAACAGGGAAAGGAGAAGACT }\end{array}$ & $\operatorname{tax} C$ & 569 & 60 \\
\hline $\mathrm{Y}$ & $\begin{array}{l}\text { F: AATTCAAACAACACTGTGCAGCCTG } \\
\text { R: GCGAGAATGGACGATTACAAAACTTT }\end{array}$ & rep $\mathrm{A}$ & 471 & 60 \\
\hline
\end{tabular}




\subsection{Análise do pan-resistoma plasmidial}

\subsubsection{Montagem e análise dos plasmídeos}

A partir dos contigs obtidos nas montagens, primeiramente foi localizado em qual contig os genes bla $a_{\text {CTX-M-8 }}$ e $m c r-1$ estavam presentes. Depois desta localização, estes contigs foram extraídos e avaliados separadamente, sendo alinhados com plasmídeos de referência e com o banco de dados do NCBI (www.ncbi.nim.nih.gov), sendo que os contigs que tiveram melhor hit com os plasmídeos foram remontados uns com os outros. Nas sequências degeneradas, foram adicionadas $\mathrm{N}$ em suas extremidades 5'e 3', a fim de estender in silico até sua circularização, de acordo com o proposto para fechamento de gaps por Cerdeira et al. (2011) e confirmados pelo software gapfiller e sequenciamento de Sanger.

As sequências completas dos plasmídeos foram anotadas utilizando os programas Geneious versão 8 (Biomatters Ltd) e Artemis (Instituto Sanger). As regiões que continham repetições invertidas, elementos móveis e origem de replicação do plasmídeo foram identificadas usando o programa Geneious e no programa ISFinder (https://wwwis.biotoul.fr/).

Análises in silico do resistoma dos plasmídeos foram avaliadas utilizando o banco de dados do ResFinder e PlasmidFinder. A determinação do pMLST foi obtida pela ferramenta online pMLST 1.4 (https://cge.cbs.dtu.dk/services/pMLST/) para análise do ST dos seguintes grupos de incompatibilidade: F, H1, H2, I1 e N.

O alinhamentos dos plasmídeos foi realizado pelo software Multiple Genome Alignment (MAUVE) (http://darlinglab.org/mauve/mauve.html), e as figuras representativas foram geradas pelos softwares EasyFig (http://mjsull.github.io/Easyfig/) e BRIG (BLAST Ring Image Generator)

\subsubsection{Análise filogenética dos plasmídeos}

Inicialmente, as sequências do gene de replicase (rep) de cada grupo de incompatibilidade plasmidial: repI1 do plasmídeo IncI1 AP005147 e repX4 do plasmídeo IncX4 CP002895, foram obtidas a partir da base de dados PlasmidFinder. Estas sequências de referência foram submetidas ao banco de dados BLASTn (https://blast.ncbi.nlm.nih.gov/Blast.cgi) e os plasmídeos com sequências completas desses grupos: IncI1 e IncX4 foram selecionados para 
análises.

A análise filogenética dos plasmídeos foi realizada usando o método Maximum Likelihood e Kimura de 2-parâmetros. O alinhamento e a construção dos dendrogramas foi realizada pelo software MEGA X. As construções iniciais das árvores filogenéticas foram obtidas automaticamente aplicando algoritmos de Neighbor-Join e BioNJ a uma matriz de distâncias entre pares estimados usando a abordagem MVI (Maximum Composite Likelihood) e selecionando a topologia com valor de log de verossimilhança superior. 


\section{RESULTADOS}

Das cepas de E. coli selecionadas para análise plasmidial deste estudo, a diversidade de hospedeiros e ecossistemas foi importante para compreensão da disseminação dos genes

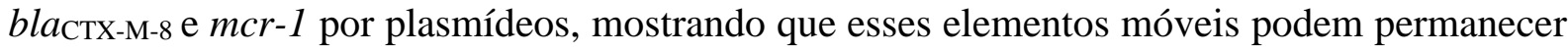
conservados e estáveis em diferentes nichos.

No antibiograma pode-se observar que 21 (84\%) isolados de E. coli foram resistentes a outras classes de antimicrobianos como: aminoglicosídeos, cloranfenicol, quinolonas, sulfonamidas e tetraciclinas. Em relação ao teste fenotípico para a produção de ESBL, 18 (72\%) cepas apresentaram o resultado positivo. Todas as cepas produtoras de ESBL, apresentaram o CIM para cefotaxima $>32 \mu \mathrm{g} / \mathrm{mL}$, em contrapartida o CIM das cepas produtoras de MCR variou de 1 até $16 \mu \mathrm{g} / \mathrm{mL}$. Os perfis fenotípicos e as análises dos sequenciamentos dos genomas bacterianos podem ser observados nas Tabelas $\mathbf{3 , 4 , 5}$.

A partir dos resultados obtidos no sequenciamento do genoma bacteriano, pode-se identificar nas cepas avaliadas outros genes de resistência aos antimicrobianos. Além do gene

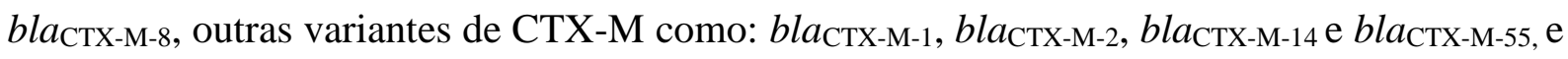
uma cepa produtora de CMY-2 foram identificadas. Adicionalmente, foram identificados outros genes de resistência a diferentes classes de antimicrobianos: $\beta$-lactâmicos (bla $\mathrm{TEM}-1$,

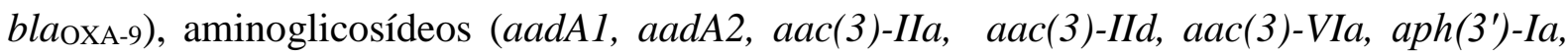
aph(3")-Ib, aph(6)-Id, strA e strB), cloranfenicol (catA1, cmlA e floR), fosfomicina (fosA3), sulfonamidas (sull e sul2), tetraciclinas (tetA e tetB) e quinolonas (qnrB19).

Em relação a diversidade clonal das cepas, foram encontrados diferentes STs, sendo alguns deles conhecidos como clones internacionais de alto risco: ST10, ST46, ST224 e ST393. Quanto a relação dos filogrupos, $80 \%(n=20)$ foram classificadas como de baixa virulência A e BI e 20\% ( $n=5)$ foram classificadas nos filogrupos de alta virulência B2 e D. Diferentes genes de virulência foram identificados nos isolados, sendo eles: astA (toxina termoestável EAST-1), cba (colicina B), cma (colicina M), celB (colicina endonuclease E2), capU (hexosyltransferase homolog), gad (glutamato decarboxilase), ipfA (formação de fímbrias polares longas), iroN (codifica proteína receptora de sideróforo), iss (increased serum survival), mchF (codifica proteína transportadora do sistema $\mathrm{ABC}$ ) e tsh (temperaturesensitive hemagglutinin). 
Tabela 3. Características fenotípicas e genotípicas das cepas de E. coli produtora de CTX-M-8

\begin{tabular}{|c|c|c|c|c|c|c|c|}
\hline Id. das cepas & $\mathrm{ST} / \mathrm{CC}^{\mathrm{a}}$ & $\begin{array}{l}\text { Filogrupo }{ }^{\mathrm{b}} / \\
\text { sorotipo }\end{array}$ & Genes de virulência & Perfil de resistência $^{c}$ & $\begin{array}{r}\text { CIM }(\mathrm{mg} / \mathrm{L})^{\mathrm{d}} \\
\text { Cefotaxima } \\
\end{array}$ & Genes de resistência & Replicons \\
\hline HEC01 & $117 /-$ & B2/ O8:H4 & $\begin{array}{l}\text { afa/draBC, cvaC, iroN, iss, } \\
\text { iutA, ipfA, ireA, mchF, pic, } \\
\text { traT, vat }\end{array}$ & $\begin{array}{l}\text { AMC, AMI, CAZ, CIP, CPM, CRO, } \\
\text { CTX, GEN, LEV, NAL, SUT }\end{array}$ & $>32$ & $\begin{array}{l}\text { bla }_{\text {СТХ-м-8, }} \text { bla } a_{\text {СТХ-М-55, }} \\
\text { bla } a_{\text {TEM-1B, }} \text { dfrA5, fos } 3 \text {, } \\
\text { sul2, strA, str } B\end{array}$ & $\begin{array}{l}\text { Col156, } \\
\text { ColRNAI, } \\
\text { FII, FIB, I1, } \\
\text { Q1 }\end{array}$ \\
\hline FSP $1333 / 09$ & $4402 /-$ & $\mathrm{A} / \mathrm{O} 9: \mathrm{H} 10$ & capU,gad, iss & $\begin{array}{l}\text { AMC, CAZ, CEF, CPM, CRO, } \\
\text { CTX }\end{array}$ & $>32$ & bla & I1 \\
\hline EC7AM & $10 / 10$ & A/O107:H54 & celb, gad & $\begin{array}{l}\text { AMC, CEF, CIP, CRO, CTX, ENR, } \\
\text { NAL }\end{array}$ & $>32$ & bla $_{\text {СТХ-м-8, } q n r B 19}$ & $\begin{array}{l}\text { ColpVC, } \\
\text { Col156, I1, Y }\end{array}$ \\
\hline $56 \mathrm{AC} 1$ & $2541 /-$ & A/O61:HNT & ipfA & $\begin{array}{l}\text { AMC, AMI, CAZ, CEF, CRO, } \\
\text { CTX, GEN, SUT, TET }\end{array}$ & $>32$ & $\begin{array}{l}\text { aadAl, aph(6)-Id, bla } \mathbf{c T X}- \\
\text { м-8, bla }{ }_{\mathrm{TEM}-1 \mathrm{~A}}, \text { sul2, tetB }\end{array}$ & $\begin{array}{l}\text { FIA, FII, HI1, } \\
\text { I1 }\end{array}$ \\
\hline ECPB17 & $224 / 58$ & A/O66:H23 & $\begin{array}{l}\text { cba, gad, ipfA, iroN, iss, } \\
m c h F, \text { tsh }\end{array}$ & $\begin{array}{l}\text { AMC, CEF, CIP, CPM, CRO, CTX, } \\
\text { ENR, NAL, SUT, TET }\end{array}$ & $>32$ & $\begin{array}{l}\text { bla }_{\text {CTX-м-8, }} \text { dfrA14, sul2, } \\
\text { tetA }\end{array}$ & $\begin{array}{l}\text { FIA, FIB, I1, } \\
\mathrm{Y}\end{array}$ \\
\hline AJ6 & $224 / 58$ & A/O66:H23 & $\begin{array}{l}\text { cba, gad, ipfA, iroN, iss, } \\
\text { mchF, tsh }\end{array}$ & $\begin{array}{l}\text { AMC, CEF, CIP, CPM, CRO, CTX, } \\
\text { ENR, NAL, SUT, TET }\end{array}$ & $>32$ & $\begin{array}{l}\text { bla }{ }_{\text {стХ-м-8, sull, sul2, tetA, }} \\
\text { dfrA14 }\end{array}$ & $\begin{array}{l}\text { FIA, FIB, } \\
\text { FIC, } \\
\text { FII, I1, Y }\end{array}$ \\
\hline $\mathrm{AJ} 20$ & $155 / 58$ & A/ONT:H20 & $\begin{array}{l}\text { cma, gad, ipfA, iss, iroN, } \\
\text { mchF }\end{array}$ & $\begin{array}{l}\text { AMC, AMI, CEF, CAZ, CPM, } \\
\text { CRO, CTX, GEN, SUT, TET }\end{array}$ & $>32$ & $\begin{array}{l}\text { aadAl, bla } \text { стх-м-8, bla }{ }_{\text {TEM-1B, }} \\
\text { sul2, tet } A, d f r A 1\end{array}$ & $\begin{array}{l}\text { FIB, FII, I1, } \\
\text { I2, Q1 }\end{array}$ \\
\hline $\mathrm{C} 6 \mathrm{O}$ & $302 /-$ & $\mathrm{A} / \mathrm{O} 36: \mathrm{H} 5$ & gad, ipfA, iss & $\begin{array}{l}\text { AMC, CAZ, CEF, CPM, CRO, } \\
\text { CTX }\end{array}$ & $>32$ & bla СТХ-М-8 $_{\text {- }}$ & I1 \\
\hline S13.2 & $8319 /-$ & A/O8:H30 & iss, gad & AMC, CEF, CRO, CTX, TET & $>32$ & bla & I1 \\
\hline
\end{tabular}

b Filogrupos de Clermont: A/B1 baixa virulência; B2/D alta virulência

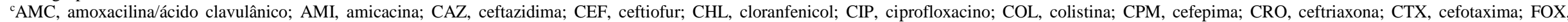

cefoxitina; ENR, enrofloxacino; GEN, gentamicina; NAL, ácido nalidíxico; LEV, levofloxacino; SUT, sulfametoxazol/trimetoprim; TET, tetrciclina;

${ }^{\mathrm{d}}$ CIM, concentração inibitória mínima (CLSI, 2018; EUCAST, 2018). 
Tabela 4. Caraterísticas fenotípicas e genotípicas das cepas de E. coli produtora de MCR-1

\begin{tabular}{|c|c|c|c|c|c|c|c|}
\hline Id. das cepas & $\mathrm{ST} / \mathrm{CC}^{\mathrm{a}}$ & $\begin{array}{l}\text { Filogrupo } / \\
\text { Sorotipo }\end{array}$ & $\begin{array}{l}\text { Genes de } \\
\text { virulência }\end{array}$ & Perfil de resistência ${ }^{c}$ & $\begin{array}{l}\begin{array}{l}\text { CIM } \\
(\mathrm{mg} / \mathrm{L})^{\mathrm{d}}\end{array} \\
\text { Colistina }\end{array}$ & Genes de resistência & Plasmídeos \\
\hline $50 \mathrm{H}$ & $354 /-$ & $\mathrm{D} / \mathrm{O} 11: \mathrm{H} 4$ & $\begin{array}{l}\text { cma, gad, ipfA, } \\
\text { iroN, iss }\end{array}$ & $\begin{array}{l}\text { AMI, AMC, CAZ, CHL, CRO, } \\
\text { CPM, CTX, GEN, SUT, TET }\end{array}$ & 16 & 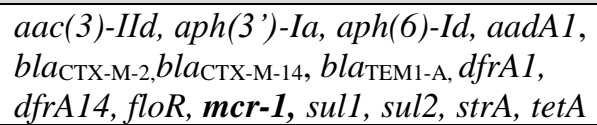 & FIB, FIC, HI2 \\
\hline $51 \mathrm{H}$ & $393 / 31$ & $\mathrm{D} / \mathrm{O} 15: \mathrm{H} 1$ & $\begin{array}{l}\text { air, eilA, gad, iha, } \\
\text { ipfA, iss, sat }\end{array}$ & CIP, NAL & 8 & $m c r-1$ & $\mathbf{X 4}$ \\
\hline $77 \mathrm{H}$ & $393 / 31$ & D/O15:H1 & $\begin{array}{l}\text { air, eilA, gad, iha, } \\
\text { ipfA, iss, sat }\end{array}$ & CIP, NAL & 8 & mcr-1 & $\mathbf{X 4}$ \\
\hline $200 \mathrm{H}$ & $3024 /-$ & A/O8:H34 & $\begin{array}{l}\text { cba, cma, gad, iha, } \\
\text { ipfA, iss, mchBCF, } \\
m c m A, t s h\end{array}$ & AMI, AMP, CIP, GEN, NAL & 16 & $\begin{array}{l}\text { aadA1, aph (3') -IIa, aph(6')-Ic, mcr-1, } \\
\text { bla OXA-9, bla } \text { TEM-1a, strA, strB, tetB }\end{array}$ & FII, X1, X4, Y \\
\hline ICBEC171S & $479 / 278$ & B1/ONT:HNT & - & CHL, SUT & 8 & floR, mcr-1, sull & $\mathrm{X} 4$ \\
\hline ICBEC146S & $224 / 58$ & A/ONT:HNT & - & AMC, CHL, FOX, SUT, TET & 1 & bla $_{\mathrm{CMY}-2}$, floR, mcr-1, sul2, tetA & FIA, I2, X4 \\
\hline ICBEC7P & $10 / 10$ & A/ONT:H32 & gad & $\begin{array}{l}\text { AMC, AMI, CEF, CRO, CTX, } \\
\text { GEN, TET, SUT }\end{array}$ & 8 & aadAl, bla ${ }_{\mathrm{CTX-м-1,}}$ mcr-1, sul2, tetA, tetB & $\begin{array}{l}\text { FII, HI2, I1, N, } \\
\text { X4 }\end{array}$ \\
\hline CF101 & $10 / 10$ & A/ONT:H32 & gad, ireA, iss & $\begin{array}{l}\text { AMC, AMI, CEF, CIP, CRO, } \\
\text { CTX, NAL, SUT, TET }\end{array}$ & 8 & $\begin{array}{l}\text { aac(3)-VIa, aadA1, bla } a_{\mathrm{CTX- \textrm {M } - 2},} \text { mcr-1, } \\
\text { sull, sul2, qnrB19, tetB }\end{array}$ & FII, HI2, I2, Q1 \\
\hline ICBEC3AM & $46 / 46$ & B1/O9:H4 & Iss, gad, $m c h F$ & $\begin{array}{l}\text { AMO, CEF, CHL, CIP, ENR, } \\
\text { NAL, SUT, TET }\end{array}$ & 4 & $\begin{array}{l}\text { aadA1, bla } \mathrm{TEM}-1 \mathrm{~B}, \text { catAl, dfrAl, dfrA8, } \\
\text { mcr-1, sul1, sul2, strA, strB, qnrB19, } \\
\text { tetA }\end{array}$ & FIB, Q1, X4 \\
\hline ICBE4C13AM & $10 / 10$ & B1/O54:H32 & gad & $\begin{array}{l}\text { AMC, AMI, CEF, CRO, CTX, } \\
\text { GEN, SUT, TET }\end{array}$ & 4 & 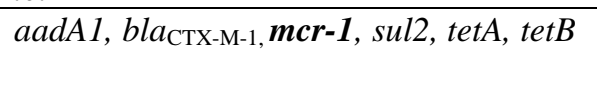 & $\mathrm{HI} 2, \mathrm{I} 1, \mathrm{~N}, \mathbf{X} 4$ \\
\hline CF131 & $533 /-$ & B1/O8:H10 & gad, iss, ipfA, $m c h F$ & $\begin{array}{l}\text { AMC, AMI, CEF, CRO, CTX, } \\
\text { GEN, SUT }\end{array}$ & $>32$ & aadA1, aac(3)-Via, , mcr-1, sul1, sul2 & FIB, FIC, I1, X4 \\
\hline
\end{tabular}

${ }^{\mathrm{a}} \mathrm{ST}$, sequence type; $\mathrm{CC}$, complexo clonal

'AMC, amoxacilina/ácido clavulânico; AMI, amicacina; CAZ, ceftazidima; CEF, ceftiofur; CHL, cloranfenicol; CIP, ciprofloxacino; COL, colistina; CPM, cefepima; CRO, ceftriaxona; CTX, cefotaxima; FOX,

cefoxitina; ENR, enrofloxacino; GEN, gentamicina; NAL, ácido nalidíxico; LEV, levofloxacino; SUT, sulfametoxazol/trimetoprim; TET, tetrciclina;

${ }^{\mathrm{d}}$ CIM, concentração inibitória mínima (CLSI, 2018; EUCAST, 2018). 
Tabela 5.Características fenotípicas e genotípicas das cde E. coli coprodutoras

\begin{tabular}{|c|c|c|c|c|c|c|c|c|}
\hline \multirow{2}{*}{ Id. das cepas } & \multirow{2}{*}{$\mathrm{ST} / \mathrm{CC}^{\mathrm{a}}$} & \multirow{2}{*}{$\begin{array}{l}\text { Filogrupo }^{\mathrm{b}} / \\
\text { Sorotipo }\end{array}$} & \multirow{2}{*}{$\begin{array}{l}\text { Genes de } \\
\text { virulência }\end{array}$} & \multirow{2}{*}{ Perfil de resistência ${ }^{c}$} & \multicolumn{2}{|c|}{ CIM $(\mathrm{mg} / \mathrm{L})^{\mathrm{d}}$} & \multirow{2}{*}{ Genes de resistência } & \multirow{2}{*}{ Plasmídeos } \\
\hline & & & & & Cefotaxima & Colistina & & \\
\hline ICBEC72H & $101 / 43$ & B1/ONT:H9 & $\begin{array}{l}\text { iroN, } m c m A, \\
m c h B C F, \text { ipfA, iss }\end{array}$ & $\begin{array}{l}\text { AMC, CAZ, CPM, CRO, } \\
\text { CTX }\end{array}$ & $>32$ & 8 & bla ${ }_{\text {СТХ-м-8, }}$ mer-1 & $\mathrm{I} 1, \mathrm{X} 4$ \\
\hline ICBEC12-3F & $206 /$ & B1/O147:H5 & $\begin{array}{l}\text { astA, cma, gad, } \\
\text { iroN, iss }\end{array}$ & $\begin{array}{l}\text { AMC, CEF, CRO, CTX, } \\
\text { TET }\end{array}$ & $>32 / 16$ & 16 & bla $_{\mathrm{CTX}-\mathrm{M}-8, \boldsymbol{m c r}-1, \text { tetA }}$ & $\begin{array}{l}\text { FII, FIB, } \\
\text { HI2, I1, X4 }\end{array}$ \\
\hline FP39-2 & $537 / 14$ & B2/O75:HNT & $\begin{array}{l}\text { fyuA, ibeA, irp2, } \\
\text { iucD, iutA, iroN, } \\
\operatorname{malX,~ompT,~tsh~}\end{array}$ & AMC, CEF, CRO, CTX & $>32$ & 4 & bla $a_{\mathrm{CTX}-\mathrm{M}-8,}, m c r-1$ & $\mathrm{I} 1, \mathrm{X} 4$ \\
\hline CF132 & $4419 /-$ & A/ONT:H2 & gad & $\begin{array}{l}\text { AMC, AMI, CEF, CRO, } \\
\text { CTX, GEN, SUT }\end{array}$ & $>32$ & 8 & $\begin{array}{l}\text { aadA1, aac(3)-VIa, bla }{ }_{\text {CTX-м-8, }} \\
\text { mcr-1, sul1, sul2 }\end{array}$ & $11, \mathrm{X} 1, \mathrm{X} 4$ \\
\hline ECPB39 & $711 /-$ & $\mathrm{B} 1 / \mathrm{O} 45: \mathrm{H} 20$ & gad, ipfA, iss & $\begin{array}{l}\text { AMI, AMC, CEF, CRO, } \\
\text { CPM, GEN, SUT, TET }\end{array}$ & $>32$ & 2 & $\begin{array}{l}\text { aac(3)-IId, aadA2, bla } a_{\text {CTX-M-8, }}, \\
\text { bla } a_{\text {TEM-1, }} \text { mcr-5.3, dfrA12, sul2, } \\
\text { strA, strB }\end{array}$ & $\begin{array}{l}\text { FII, FIB, } \\
\text { FIA, I1, } \\
\text { HI1A, Q1 }\end{array}$ \\
\hline
\end{tabular}

${ }^{a} \mathrm{ST}$, sequence type; $\mathrm{CC}$, complexo clonal

b Filogrupos de Clermont: A/B1 baixa virulência; B2/D alta virulência

'AMC, amoxacilina/ácido clavulânico; AMI, amicacina; CAZ, ceftazidima; CEF, ceftiofur; CHL, cloranfenicol; CIP, ciprofloxacino; COL, colistina; CPM, cefepima; CRO, ceftriaxona; CTX, cefotaxima; FOX,

cefoxitina; ENR, enrofloxacino; GEN, gentamicina; NAL, ácido nalidíxico; LEV, levofloxacino; SUT, sulfametoxazol/trimetoprim; TET, tetrciclina;

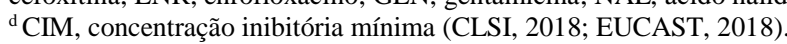


Em relação aos plasmídeos, foram identificados diferentes grupos de incompatibilidade nas cepas sequenciadas, entre eles: ColRNA, Col156, ColpVC, IncFII, IncFIA, IncFIB, IncFIC, IncI1, IncI2, IncHI1, IncHI2, IncN, IncQ, IncY, IncX1 e IncX4. Inicialmente, através de análises in silico do genoma bacteriano foi confirmado a localização dos genes $b l_{\mathrm{CTX}-\mathrm{M}-8}$ nos plasmídeos IncI1, e do gene $m c r-1$ nos plasmídeos IncX4.

$\mathrm{Na}$ padronização dos ensaios de conjugação em caldo, diferentes períodos de incubação à $37^{\circ} \mathrm{C}$ foram avaliados. $\mathrm{O}$ período de 18 horas de incubação, foi o que apresentou a melhor recuperação das cepas transconjugantes de ambos os plasmídeos IncI1 e IncX4.

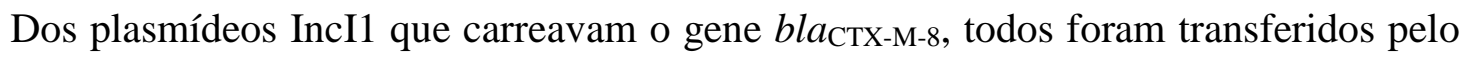
método de conjugação em caldo, para linhagens receptoras de E.coli $\mathrm{C} 600^{\mathrm{STR}}$. O fenótipo e genótipo das cepas transconjugantes foram confirmados, e somente os plasmídeos do tipo IncI1 foram transferidos por este ensaio. O CIM das cepas transconjugadas diminuiu em até duas diluições em comparação com as cepas selvagens. Todos os plasmídeos IncI1 apresentaram o tamanho de $\sim 90 \mathrm{~kb}$ (Tabela 6).

Dentre os plasmídeos IncX4 que carreavam o gene $m c r-1$, cinco foram transferidos pelo ensaio de conjugação nas linhagens receptoras de E. coli $\mathrm{C} 600^{\mathrm{STR}}$. Adicionalmente, os oito plasmídeos restantes, não foram mobilizados pelos ensaios de conjugação e foram testados em diferentes linhagens receptoras, mais de uma vez. A transferência dos oito plasmídeos foi realizada por transformação em linhagens competentes de E. coli TOP 10 . O fenótipo das cepas transconjugadas e/ou transformadas foi confirmado, sendo que o CIM das cepas diminuiu em até quatro diluições em comparação com as cepas selvagens. O genótipo de todos os plasmídeos mobilizados foi confirmado, e apenas os plasmídeos IncX4 foram transferidos nesses ensaios. O tamanho dos plasmídeos IncX4 variou entre 32 e $34 \mathrm{~kb}$ (Tabela 7).

Em relação à diversidade clonal dos plasmídeos IncI1 através do pMLST, foi

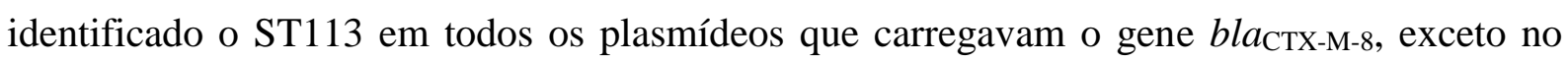
plasmídeo da cepa isolada de infecção humana (ICBEC72H) que apresentou o ST131. Adicionalmente, para os plasmídeos IncX4 não há métodos de tipagem molecular para diferenciação de STs e clones prevalentes. 
Tabela 6. Características gerais dos plasmídeos IncI1

\begin{tabular}{llllllll}
\hline Plasmídeos & Origem/Fonte & Ano & $\begin{array}{l}\text { CIM }(\boldsymbol{\mu g} / \mathbf{m l}) \\
\text { Cefotaxima }^{\mathbf{a}}\end{array}$ & Mobilização & $\begin{array}{l}\text { CIM }(\boldsymbol{\mu g} / \mathbf{m l}) \\
\text { Cefotaxima }(\mathbf{T C})^{\mathbf{b}}\end{array}$ & Tamanho & pMLST \\
\hline pHEC01 & Humana/ fezes & 2017 & $>32$ & TC & 16 & $87 \mathrm{~kb}$ & 113 \\
p1333/09 & Esgoto tratado/ lodo ativado & 2009 & $>32$ & TC & 8 & $89 \mathrm{~kb}$ & 113 \\
pEC7AM & Praia/ água do mar & 2016 & $>32$ & TC & 16 & $86 \mathrm{~kb}$ & 113 \\
56AC1 & Cachorro/swab retal & 2012 & $>32$ & TC & 16 & $89 \mathrm{~kb}$ & 113 \\
pECPB17 & Gato/ swab retal & 2015 & $>32$ & TC & 16 & $89 \mathrm{~kb}$ & 113 \\
pAJ6 & Cágado/ swab cloacal & 2017 & $>32$ & TC & 16 & $88 \mathrm{~kb}$ & 113 \\
pAJ20 & Cágado/ swab cloacal & 2017 & $>32$ & TC & 16 & $88 \mathrm{~kb}$ & 113 \\
pC6O & Bivalve/ ostra & 2016 & $>32$ & TC & 16 & $89 \mathrm{~kb}$ & 113 \\
pS13.2 & Crustáceo/ siri & 2017 & $>32$ & TC & 16 & $98 \mathrm{~kb}$ & 113 \\
pICBEC72Hctx & Humana/ ferida & 2016 & $>32$ & TC & 16 & $82 \mathrm{~kb}$ & 131 \\
pCF132 & Carne de frango/ peito & 2016 & $>32$ & TC & 16 & $89 \mathrm{~kb}$ & 113 \\
pICBEC12-3F & Frango/ swab cloacal & 2013 & $>32$ & TC & 16 & $89 \mathrm{~kb}$ & 113 \\
pFP39-2 & Peru / swab cloacal & 2013 & $>32$ & TC & 16 & $88 \mathrm{~kb}$ & 113 \\
pECPB39 & Cavalo/ secreção pulmonar & 2012 & $>32$ & TC & 16 &
\end{tabular}

${ }^{\text {a }}$ Ponte de corte para Cefotaxima $>4 \mu \mathrm{g} / \mathrm{ml}$, segundo CLS1 2018.

${ }^{\mathrm{b}} \mathrm{TC}$, transconjugantes 
Tabela 7. Características gerais dos plasmídeos IncX4

\begin{tabular}{|c|c|c|c|c|c|c|c|}
\hline Plasmídeos & Origem/Fonte & Ano & $\begin{array}{l}\text { CIM ( } \mu_{\mathrm{g} / \mathrm{ml})} \\
\text { Colistina }^{\mathrm{a}}\end{array}$ & Mobilização & $\begin{array}{l}\text { CIM }(\mu \mathrm{g} / \mathrm{ml}) \\
\text { Colistina }(\mathrm{TC} / \mathrm{TF})^{\mathrm{b}}\end{array}$ & Tamanho & IS \\
\hline$\overline{\mathrm{p} 51 \mathrm{H}}$ & Humana/ urina & 2016 & 8 & $\mathrm{TF}$ & 2 & $33,3 \mathrm{~kb}$ & IS26 \\
\hline p77H & Humana/ urina & 2016 & 8 & $\mathrm{TF}$ & 2 & $33,3 \mathrm{~kb}$ & IS26 \\
\hline p200H & Humana/ urina & 2017 & 16 & $\mathrm{TF}$ & 2 & $33,3 \mathrm{~kb}$ & IS26 \\
\hline pICBEC171S & Suíno/ swab retal & 2012 & 8 & $\mathrm{TC}$ & 2 & $31,2 \mathrm{~kb}$ & IS26 \\
\hline pICBEC146S & Suíno/ swab retal & 2012 & 1 & $\mathrm{TC}$ & 0,5 & $33,4 \mathrm{~kb}$ & IS26 \\
\hline pICBEC7P & Carne de frango/ peito & 2016 & 8 & $\mathrm{TF}$ & 2 & $34,9 \mathrm{~kb}$ & IS1294 \\
\hline pICBEC3AM & Praia/ água do mar & 2016 & 4 & $\mathrm{TF}$ & 2 & $33,3 \mathrm{~kb}$ & IS26 \\
\hline pICBE4C13AM & Praia/ água do mar & 2016 & 4 & $\mathrm{TF}$ & 1 & $34,9 \mathrm{~kb}$ & IS 1294 \\
\hline pICBEC72Hmcr & Humana/ ferida & 2016 & 8 & $\mathrm{TC}$ & 2 & $33,6 \mathrm{~kb}$ & IS26 \\
\hline pCF132 & Carne de frango / peito & 2016 & 8 & $\mathrm{TF}$ & 2 & $33,3 \mathrm{~kb}$ & IS26 \\
\hline pCF131 & Carne de frango/ peito & 2016 & 8 & $\mathrm{TF}$ & 2 & $33,3 \mathrm{~kb}$ & IS26 \\
\hline pICBEC12-3F & Frango/ swab cloacal & 2013 & 4 & $\mathrm{TC}$ & 2 & $34,2 \mathrm{~kb}$ & IS26 \\
\hline pFP39-2 & Peru / swab cloacal & 2013 & 4 & $\mathrm{TC}$ & 1 & $33,3 \mathrm{~kb}$ & IS26 \\
\hline
\end{tabular}

aPonto de corte para colistina $>2 \mu \mathrm{g} / \mathrm{ml}$, segundo EUCAST, 2018.

${ }^{\mathrm{b}} \mathrm{TC}$, transconjugantes; TF, transformantes 
Em relação aos plasmídeos IncI1, o plasmídeo pICBEC72Hctx da cepa humana (ICBEC72H), foi construído utilizando como referência o plasmídeo de $b l a_{\text {CTX-M-8 }}$ de $K$. pneumoniae 2694TF (acesso GenBank KT935446.1). No alinhamento do contig ( 63 kb) contra o plasmídeo $2694 \mathrm{TF}$ foi observado $70 \%$ de identidade, o que possibilitou a circularização do plasmídeo.

A partir do plasmídeo do pICBEC72Hctx foi construído o plasmídeo ambiental pEC1333 e animal pFP39-2 que apresentaram um grau de homologia de 97\% com o plasmídeo da cepa humana. A partir dessas construções, os plasmídeos pHECO1, pICBEC7AM, p56AC1, pECPB17, pICBEC12-3F puderam ser montados e circularizados. A relação de homologia entre esses plasmídeos foi de 99\%. A montagem dos plasmídeos pCF132, pAJ6, pAJ7, pC6O, pS13.2 e pECPB39ctx, foi realizada, entretanto não foi possível obtê-los circularizados.

Através do alinhamento pelo MAUVE de todos os plasmídeos construídos, foi observado a arquitetura conservada entre todos os plasmídeos IncI1/ST113, com 98\% de identidade em seus nucleotídeos. A comparação de todas as sequências, mostrou que todos os plasmídeos apresentaram os módulos genéticos clássicos dos plasmídeos IncI1: replicação (repY), estabilidade (parA, parM, kor, ibfa) e transferência (Figura 8). A região de transferência conjugativa dos plasmídeos foi codificada por uma região de $\sim 34 \mathrm{~kb}$ consistindo de genes que são agrupados funcionalmente: traA-D, pilJ-V, tra / trb, nikAB e excA-traY. Ambos os plasmídeos pICBEC72H, pFP39-2 e pEC1333/09 foram ligeiramente diferentes em termos da presença ou ausência de vários genes putativos.

Em todos os plasmídeos IncI1/ST113 foram identificados os genes pndCA, que codificam um sistema de toxina-antitoxina, responsáveis pela morte pós-segregacional das células filhas que não receberem o plasmídeo. 
Figura 8. Análise comparativa dos plasmídeos IncI1 de diferentes origens
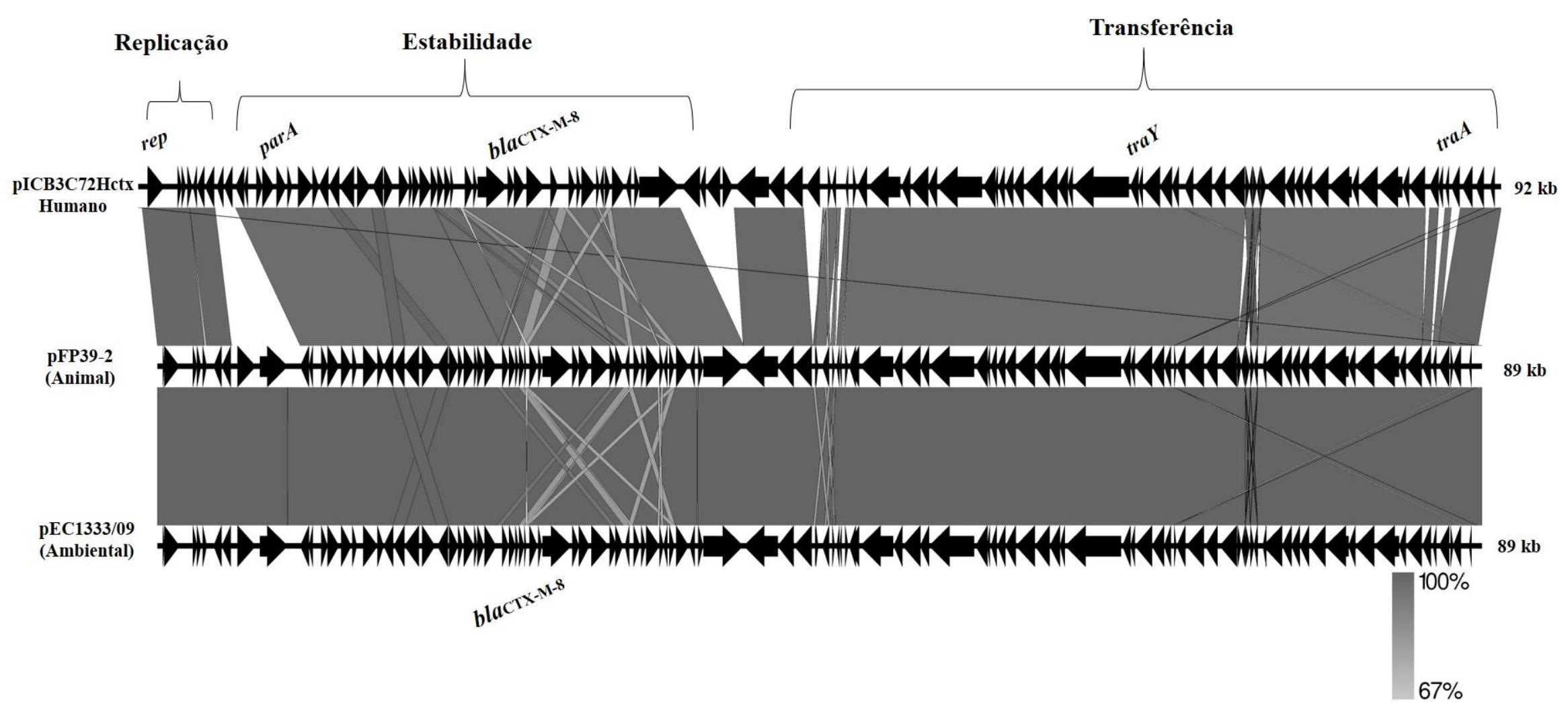

Legenda: O plasmídeo humano ICBEC72H apresentou 97\% de homologia com os plasmídeos pFP39-2 e pEC1333/09. A análise comparativa foi realizada usando o software Easyfig versão 2.2.2. 
Em todos os plasmídeos não foram encontrados genes de resistência, além do bla ${ }_{\mathrm{CTX}}$

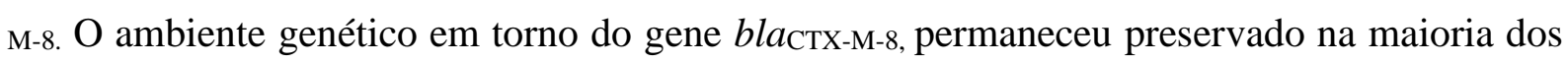

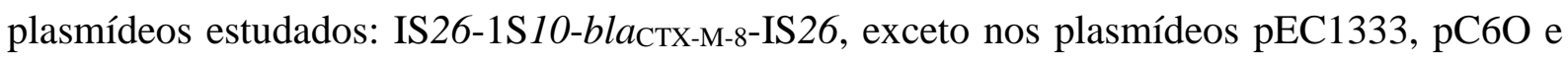
pS13.2, onde a IS26 permaneceu apenas upstream ao gene.

Foi realizada a análise comparativa dos plasmídeos ST113 e ST131, com cinco

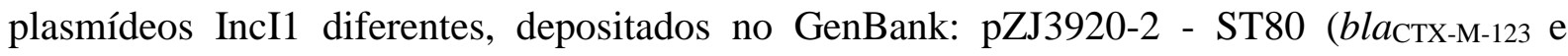

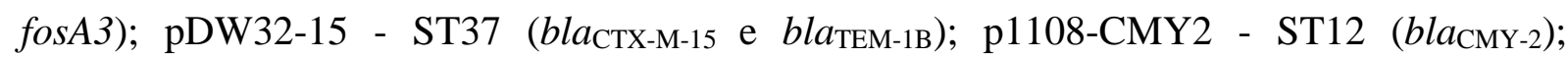
pSA20101045.1 - ST267 (sem genes de resistência); pSa21-TC-CIP - ST162 (qnrS, aph(6)$I d$, $a p h(3$ ")-Ib e tetC). O alinhamento realizado no MAUVE, mostrou que os plasmídeos IncI1 apresentaram $80 \%$ de sua arquitetura conservada (incluindo regiões de replicação, estabilidade e transferência), independente do ST plasmidial e da ausência e/ou presença de genes de resistência. Adicionalmente, os pICBEC72H, pFP39-2, pEC1333, pHECO1, pICBEC7AM, p56AC1, pECPB17, pICBEC12-3F exibiram entre 96-98\% de identidade com o plasmídeo R64, considerado o protótipo do grupo IncI1/ST13.

Para filogenia dos plasmídeos IncI1 foi realizada o alinhamento dos genes dos esquemas do pMLST, alinhamento do gene rep e alinhamento global de nucleotídeos usando o alinhador MAUVE. Para essas análises, foram selecionados os plasmídeos deste estudo: pICBEC72H, pEC1333/09 e EC1333/09, e plasmídeos de diferentes origens, regiões geográficas e diferentes STs: ST4, ST13, ST12, ST16, ST23, ST26 ST37, ST80, ST166 e ST136.

$\mathrm{Na}$ análise filogenética foi observada a formação de dois grandes clusters (I e II) (Figura 9). O cluster I, apresentou mais ramificações, e foi agrupado em dois subgrupos (Ia e Ib). O subgrupo Ia apresentou o agrupamento de 13 plasmídeos de diferentes STs, sem distinção de fonte de isolamento, país e presença e/ou ausência de genes de resistência. Os três plasmídeos deste estudo pICBEC72H, pICBEC1333/09 e pFP39-2, estiveram presentes neste subgrupo, juntamente com o plasmídeo brasileiro p2964TF. No subgrupo Ib o plasmídeo ambiental pCMY-1225 não apresentou agrupamento com nenhum outro plasmídeo.

No cluster II, houve agrupamento de dois plasmídeos de origem humana e um animal, de distintos STs: ST12, ST16 e ST80. Entretanto, nessa análise filogenética não houve a formação de clones, nem mesmo nos plasmídeos que pertenciam ao mesmo ST ou que carregavam o mesmo gene de resistência. 
Figura 9. Análise filogenética de plasmídeos IncI1 de diferentes origens

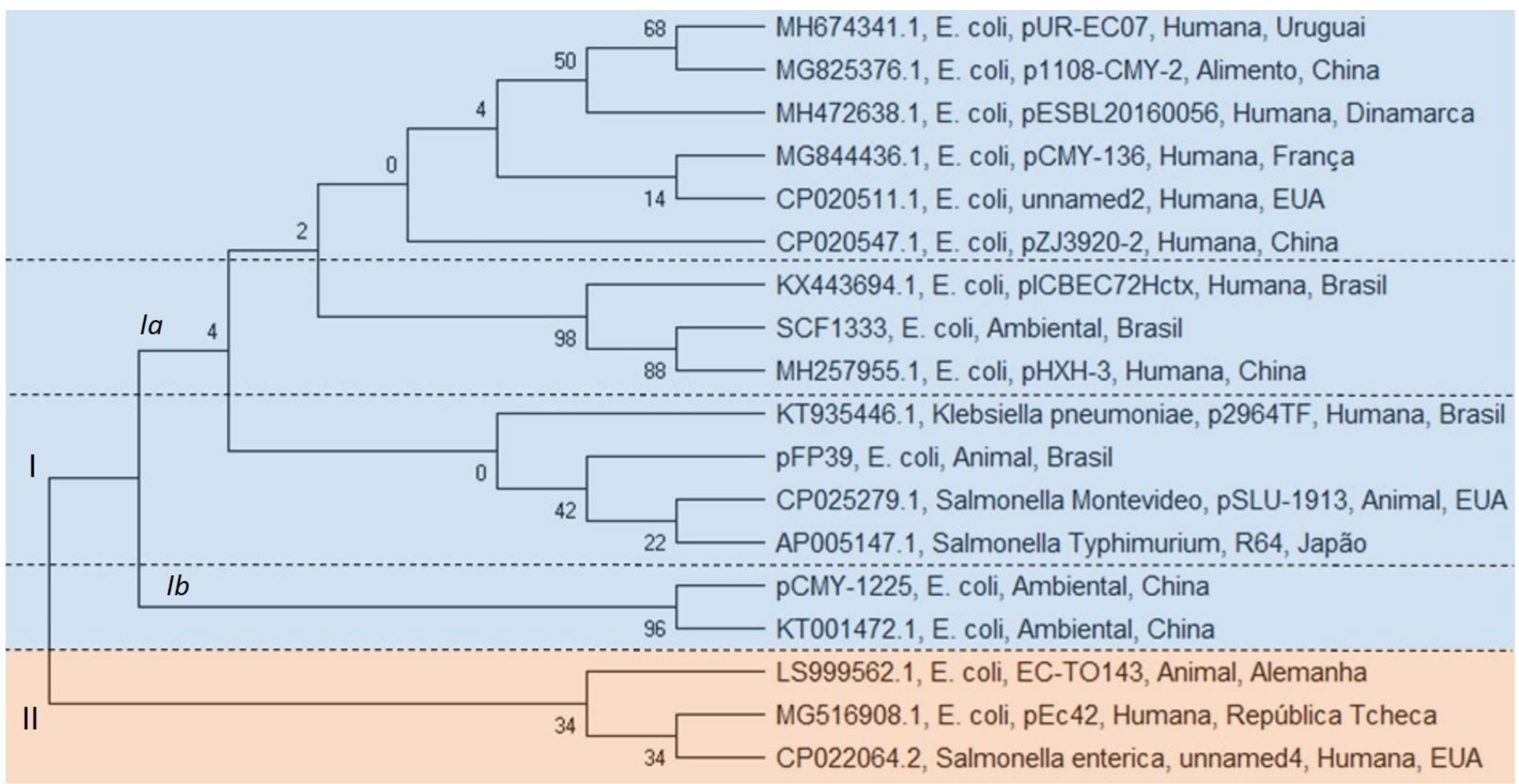

Legenda: A análise filogenética foi realizada a partir de 318 sequências de plasmídeos completos depositados no GenBank. A construção do dendrograma foi realizado utilizando o método Maximum Likelihood pelo software MEGA X. 
Em relação aos plasmídeos IncX4, o plasmídeo pICBEC72Hmcr foi o primeiro a ser construído, a partir, da identificação do gene mcr-1 em um contig de $\sim 30 \mathrm{~kb}$, facilitando a circularização desse plasmídeo. No alinhamento do contig contra o banco de dados do BLASTn, foi observado, o perfil de 99\% de identidade com plasmídeos IncX4 que carreavam o gene mcr-1 em outros países. O alinhamento usando software MAFFT entre o pICBEC72Hmcr e os plasmídeos pmcr1_IncX4 (acesso GenBank KU761327.1), de uma cepa de $K$. pneumoniae isolada de amostra clínica humana na China, e pESTMCR (acesso do GenBank KU743383.1), de uma cepa de E. coli isolada de esterco de suínos na Estônia, apresentou 99,9\% de identidade nucleotídica. Adicionalmente, o plasmídeo pICBEC72Hmcr apresentou 96,3\% de identidade com pAF48 (acesso do GenBank KX032520.1), devido a deleção de $\sim 1,2$ kb no gene de replicação pir do pAF48 (Figura 10).

$\mathrm{Na}$ construção do pICBEC7P, foi verificado que gene $m c r-1$ e o replicon IncX4 estavam no contig de 15,5 kpb. Estes contigs foram concatenados e a diferença dos gaps foi solucionada por meio do software GapFiller, para o fechamento do plasmídeo. A construção do plasmídeo pICBEC7P foi realizada utilizando os contigs que apresentaram $>99 \%$ de identidade com o plasmídeo pICBEC72Hmcr. O plasmídeo pICBEC7P apresentou 95,2\% de identidade de nucleotídeos com o pICBEC72Hmcr. O plasmídeo pICBEC7P, apresentou uma região diferente dos outros plasmídeos IncX4 identificados, devido ao surgimento da IS 1294 truncando o gene de mobilização mobA (Figura 11). 
Figura 10. Análise comparativa entre os plasmídeos IncX4

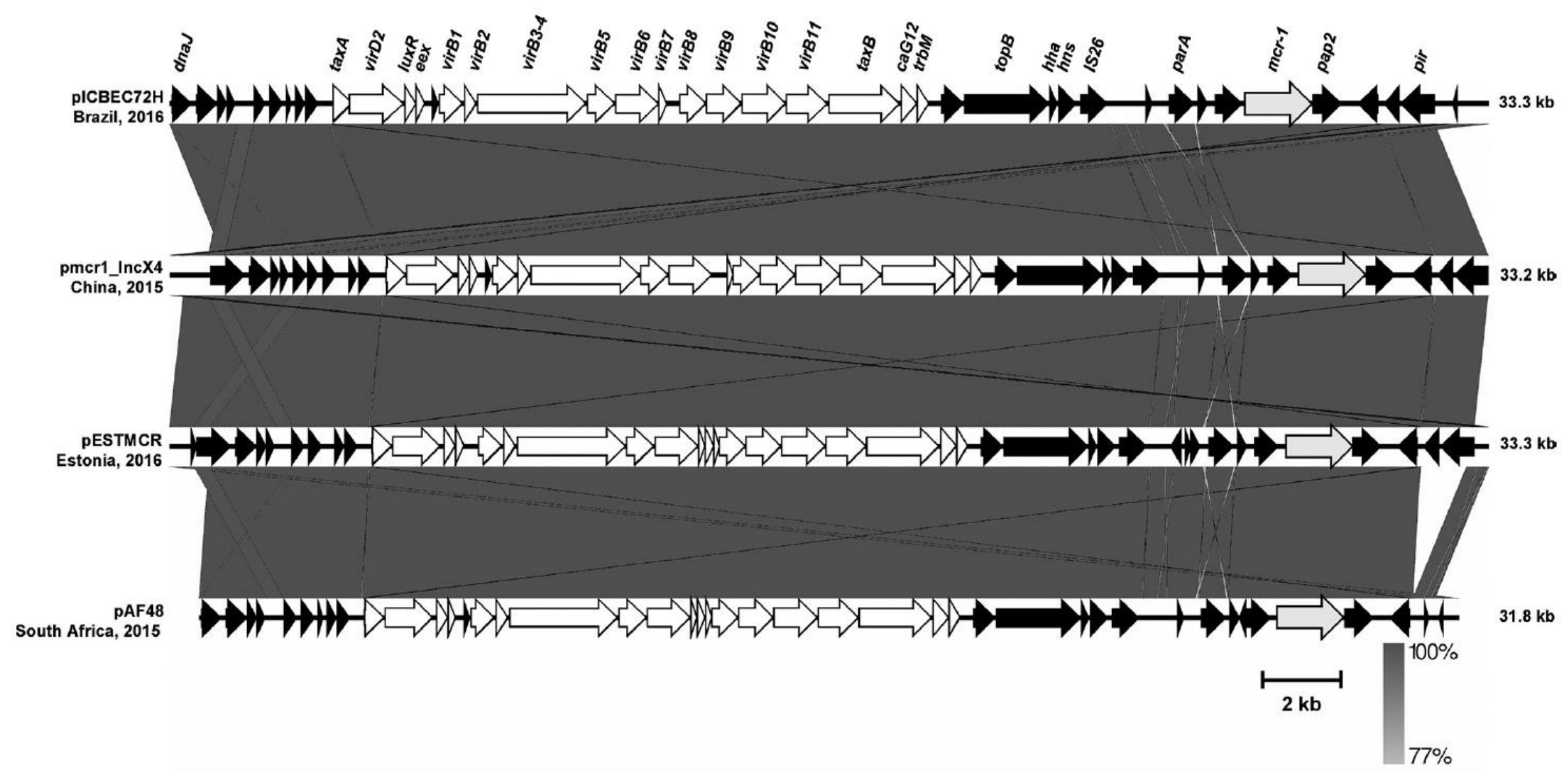

Legenda: Os plasmídeos pICBEC72H, pmcr-1_IncX4 e pESTMCR, apresentaram 99,9\% de identidade nucleotídica, diferentemente do AF48 que apresentou 96,3\% de identidade com os respectivos plasmídeos. A análise comparativa foi realizada usando o software Easyfig versão 2.2.2 (FERNANDES et al., 2016). 
Figura 11. Análise comparativa entre os plasmídeos pICBEC72Hmcr e pICBEC7P

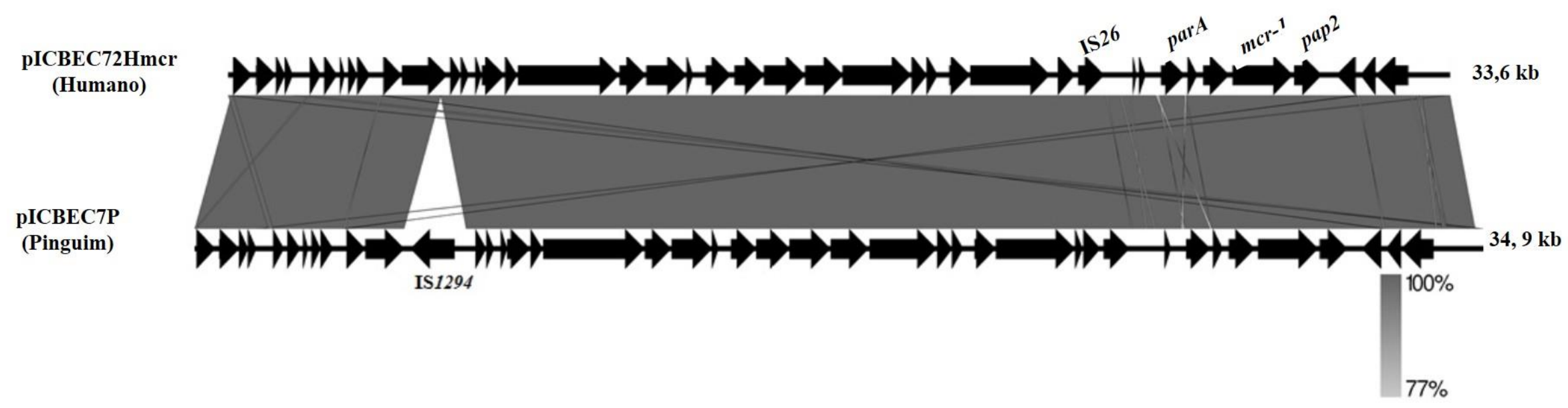

Legenda: Os plasmídeos pICBEC72Hmcr e pICBEC7P apresentaram identidade genética de 95,2\%. No pICBEC7P foi encontrada a IS1294, truncando o gene mobA. A análise comparativa foi realizada usando o software Easyfig versão 2.2.2 (SELLERA et al., 2017). 
A partir das montagens dos plasmídeos pICBEC72Hmcr e pICBEC7P, os outros plasmídeos IncX4 ( $\mathrm{n}=13$ ) foram construídos e analisados utilizando ambos como referência. Através do alinhamento de todos os plasmídeos IncX4, foi observada uma alta similaridade genética entre eles, que variou de 95 a 99,9\% de identidade entre seus nucleotídeos. Interessantemente, o plasmídeo pICBEC13AM foi o único que apresentou $>99,9 \%$ de homologia com o plasmídeo pICBEC7P, esse plasmídeo foi isolado de uma E. coli ST10, sendo o mesmo clone da cepa ICBEC7P, recuperada de uma amostra de ambiente marinho.

Todos os plasmídeos IncX4 deste estudo, apresentaram a mesma arquitetura e estrutura, incluindo genes de estabilidade (hns e par), transferência (virB1-virB11 e taxAC) e replicação (pir), conservados entre si. Além disso, não foi identificado outros genes de resistência nesses plasmídeos, além do mcr-1. A IS26 esteve presente em todos eles, próximo ao gene $m c r-1$. O elemento de inserção ISApI1 presente em plasmídeos IncHI2 e IncI2 que carregam o gene $m c r-1$, não foi encontrado em nenhum dos plasmídeos IncX4 deste estudo. A Figura 12, ilustrada a representação comparativa de sete plasmídeos deste estudo de diferentes fontes: pICBEC7P (pinguim), pICBEC72Hmcr (humano), pICBEC200H (humano), pICBEC171F (frango), pICBEC146S (suíno), pCF132 (carne de frango) e pICBEC3AM (praia). Adicionalmente, os plasmídeos IncX4 foram alinhados contra outros plasmídeos IncX4 brasileiros que carregavam o gene $m c r-1$, e não foi encontrada nenhuma diferença significativa na arquitetura entre eles.

Foi realizada a análise comparativa dos plasmídeos brasileiros pICBEC72Hmcr, pICBEC7P e pICBEC13AM, contra 26 plasmídeos IncX4 que carreavam o gene mcr- 1 de diferentes espécies bacterianas, países e origens, a partir de sequências depositadas no banco de dados do NCBI. O alinhamento desses plasmídeos revelou > 98\% de identidade genética, com exceção pICBEC7P e pICBEC13AM, que apresentaram 95\% de identidade (Figura 13). 
Figura 12. Análise comparativa dos plasmídeos IncX4 que carregam o gene $m c r-1$

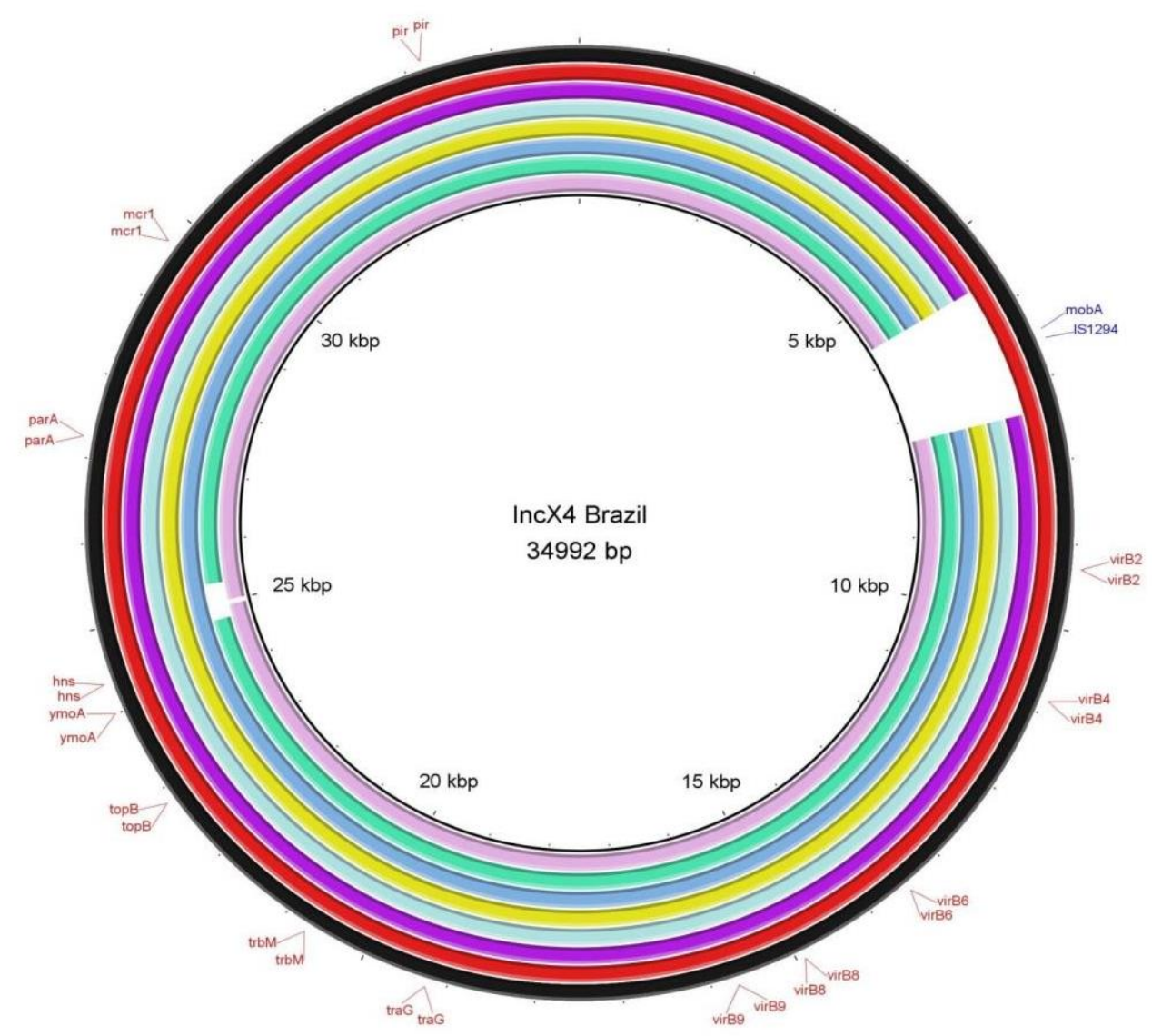

Legenda: Os anéis coloridos representam os plasmídeos. Vermelho, pICBEC7P (pinguim); lilás, pICBEC72Hmcr (humano); azul-claro, pICBEC200H (humano); amarelo, pICBEC171F (frango); azul, pICBEC146S (suíno); verde, pCF132 (carne de frango) e rosa claro, pICBEC3AM (praia). A figura foi gerada com a ferramenta BRIG (Blast Ring Image Generator) (Fonte: FERNANDES, 2019). 
Figura 13. Esquema representativo dos plasmídeos IncX4 brasileiros e outros de diferentes países

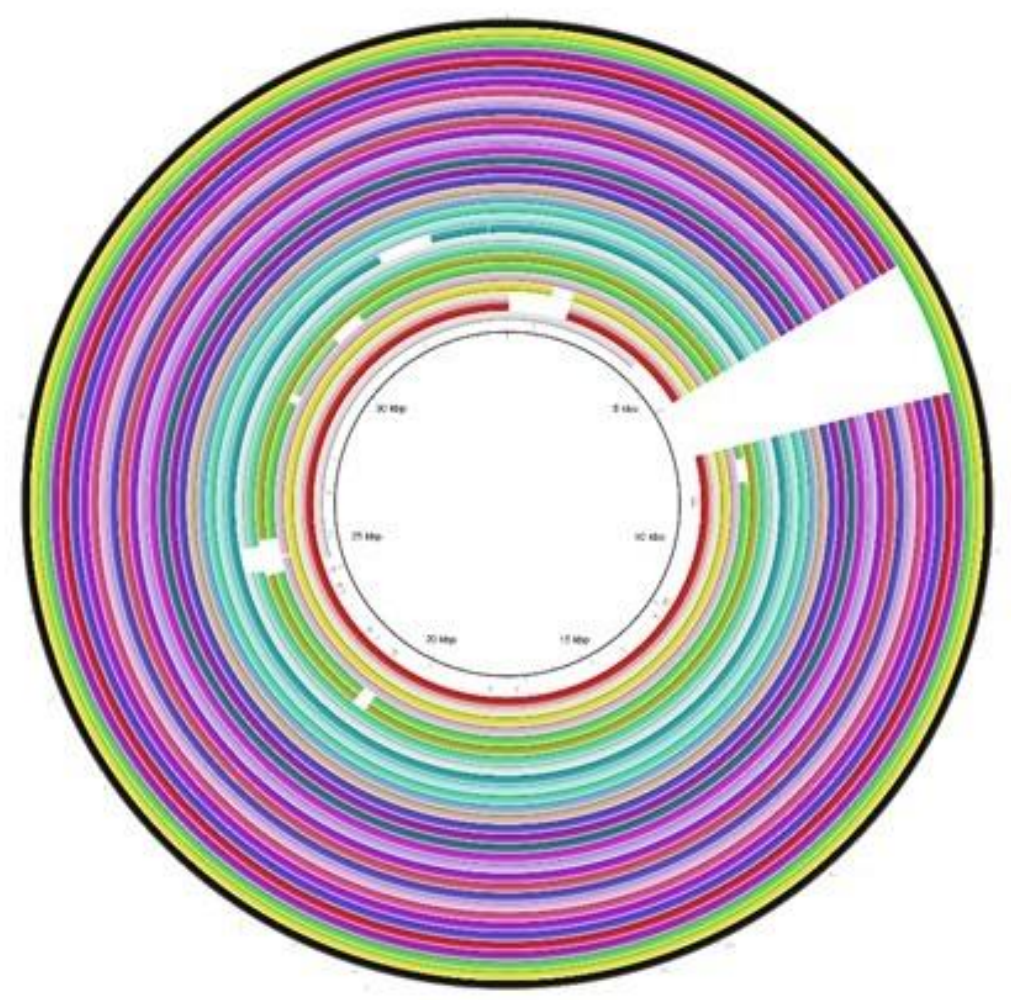

Legenda: Análise comparativa dos plasmídeos brasileiros pICBEC72Hmcr, pICBEC7P e pICBEC13AM, contra 26 plasmídeos IncX4 que carreavam o gene mcr-1. Os anéis coloridos representam os plasmídeos, a ordem dos números de acessos, está de fora para dentro: pICBEC7P (CP017246.1), pICBEC13AM (KY770025) pICBEC72Hmcr (CP015977.1), CP016550.1， CP018773.2， KU647721.2， KU743383.1, KU761327.1， KX032520.1， KX084392.1， CP002895.1， KX129783.1， KX236309.1， KX254343.1, KX447768.1, KX570748.1, KX772777.1, JN194214.1, LT598652.2, CP017246.1, KY770023.1, KY770024.1, KY770025.1, CP021419.1, CP021418.1, CM007714.1, MRDN0100003.1, CM008162.1 e MQME01000048.1. 
A análise filogenética dos plasmídeos IncX4 foi realizada a partir de sequências completas, depositadas no GenBank. Foram selecionados plasmídeos de diferentes localizações geográfica e de diferentes fontes de isolamento. Inicialmente foram alinhados 62 plasmídeos IncX4, com a presença de genes de resistência a outras classes de antimicrobianos, e plasmídeos sem genes de resistência. Entretanto, devido a semelhança entre os plasmídeos IncX4 e por não apresentarem agrupamentos específicos, optou-se por diminuir o número de sequências e focalizar a análise somente nos plasmídeos portadores do gene $m c r$ - 1 . Assim, foram utilizados 3 plasmídeos IncX4 que carregavam o gene $m c r-1$ e dois plasmídeos IncX4 que carregavam genes bla

$\mathrm{Na}$ análise filogenética foi observada a formação de dois grandes clusters (I e II). No cluster I, nove plasmídeos, incluindo os deste estudo (pICBEC72H, pICBEC7P, pICBEC3AM e pICBEC13AM) foram agrupados juntamente com plasmídeos identificados na França, Bélgica e China. Os plasmídeos pICBEC72H, pICBEC7Pe pICBEC3AM apresentaram $100 \%$ de identidade entre seus nucleotídeos. Entretanto nesse cluster, O plasmídeo brasileiro pC153mcr de origem humana, permaneceu em um clado isolado.

O cluster II, seis plasmídeos foram agrupados, sendo que dois clados apresentaram os plasmídeos pCSZ4 (China) e pMCRpoa (Brasil) tiveram 100\% de identidade nucleotídica. Dentro deste cluster, foram agrupados os plasmídeos com genes de resistência bla $a_{\text {CTX-M-14 e }}$

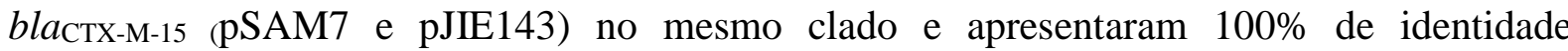
nucleotídica.

Após a construção da filogenia, foi realizado um alinhamento no MAUVE, com os plasmídeos representativos de cada cluster. Assim, foi observado o alto grau de conservação entre os plasmídeos IncX4, com pequenas variações relacionadas a presença ou ausência de genes putativos. 
Figura 14. Análise filogenética dos plasmídeos IncX4

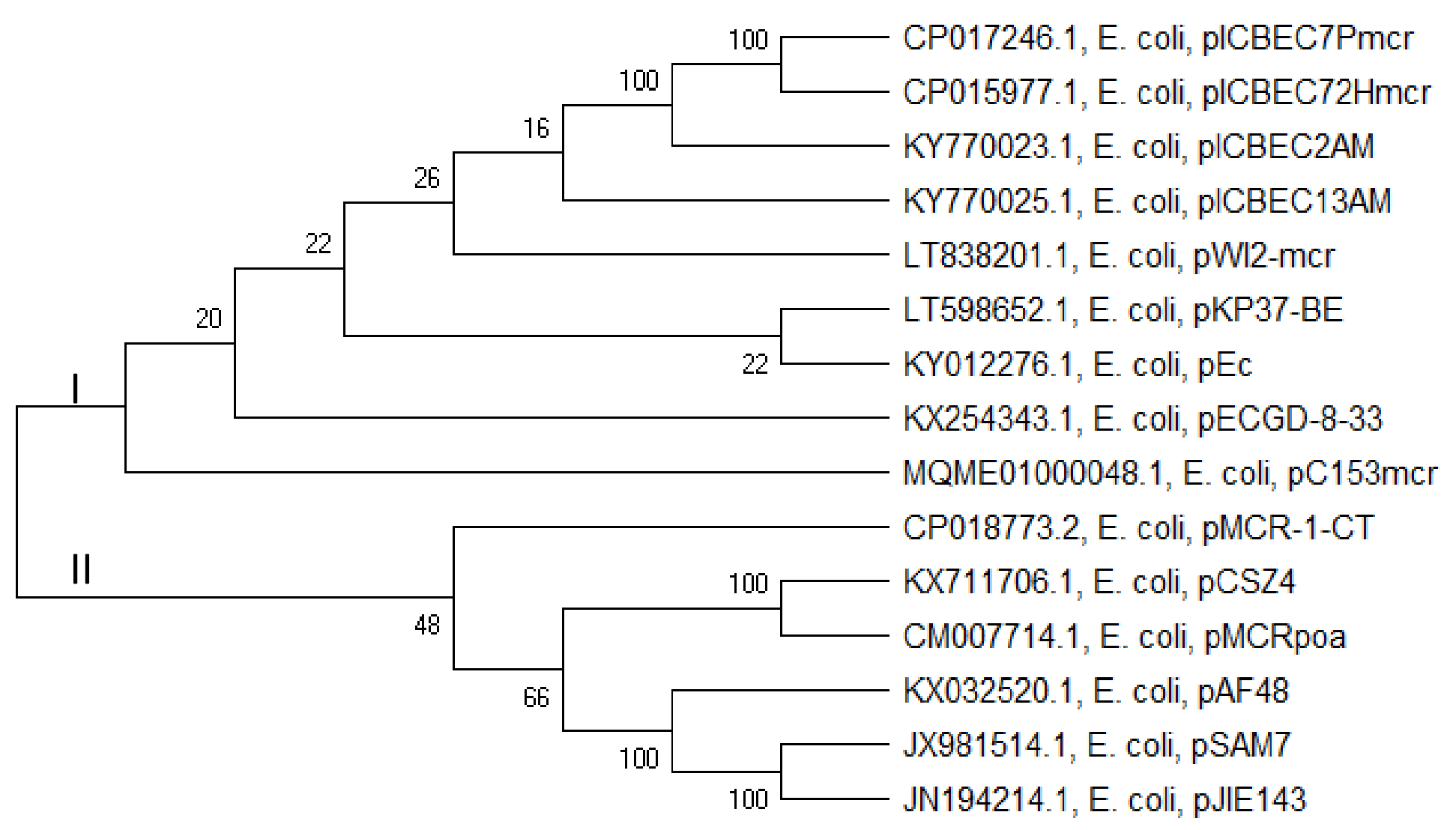

Legenda: Análise filogenética foi realizada a partir de 15 sequências de plasmídeos IncX4. A construção do dendrograma foi realizada pelo software MEGA X. 
Neste estudo, foi detectado pela primeira vez no Brasil, a presença de plasmídeos IncHI2 carregando o gene mcr-1. Os plasmídeos IncHI2 são plasmídeos grandes e mais complexos de serem construídos, sendo assim, a análise plasmidial foi realizada durante o período de estágio no exterior no Istituto Superiore di Sanità, em Roma, Itália, supervisionada pela Dra. Alessandra Carattoli.

Inicialmente, após a montagem dos genomas, os resultados gerados usando o ResFinder e o PlasmidFinder revelaram que em ambos os isolados, o gene mcr-l estava localizado no mesmo contig de um replicon repHI2. Foram identificados outros genes de resistência, a cepa de E. coli $50 \mathrm{H}$ apresentou dois genes adicionais de ESBL: bla $_{\mathrm{CTX}-\mathrm{M}-14 \mathrm{e}}$

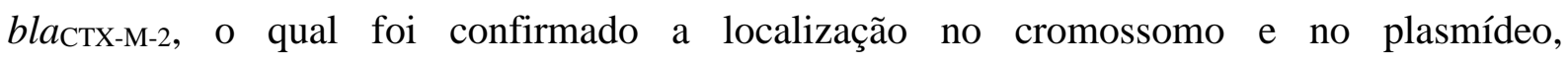
respectivamente. Na cepa CF101 foi identificado o gene bla $a_{\mathrm{CTX}-\mathrm{M}-2}$ no cromossomo.

Foram encontrados diferentes grupos de incompatibilidade plasmidial, na cepa $50 \mathrm{H}$ (FIB, FIC e pO111), e na cepa CF101 (FII, I2 e Q1). Curiosamente, a cepa de E. coli 50H

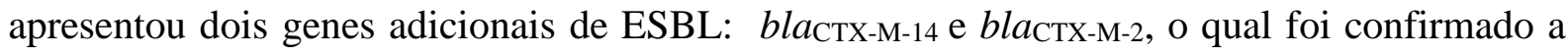
localização no cromossomo e no plasmídeo, respectivamente. Na cepa CF101, o gene bla $a_{\text {CTX- }}$ M-2 foi detectado no cromossomo. O pMLST de ambos os plasmídeos IncHI2 foi identificado como ST4 (smr0018- alelo 4 e smr0199- alelo 2).

A transferência dos plasmídeos IncHI2 das cepas 50H e CF101 foi realizada pelo ensaio de conjugação em ágar, e somente ocorreu em temperatura de $25^{\circ} \mathrm{C}$ na linhagem receptora de E. coli $\mathrm{CSH} 26^{\mathrm{RIF}}$. O fenótipo e genótipo das cepas transconjugadas foram confirmados, e apenas o plasmídeo IncHI2 foi transferido. Assim, foi confirmado na cepa transconjugante $(\mathrm{p} 50 \mathrm{H})$, a presença adicional de outros genes de resistência nesse plasmídeo:

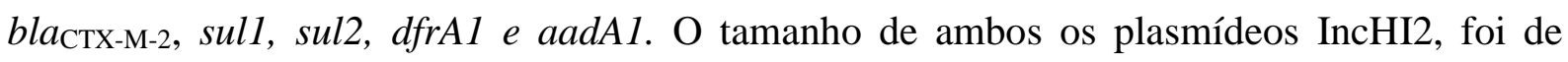
$\sim 200 \mathrm{~kb}$.

Durante a montagem dos plasmídeos IncHI2, algumas limitações foram encontradas, e não foi possível realizar a circularização desses plasmídeos. $\mathrm{Na}$ cepa $50 \mathrm{H}$, a construção do plasmídeo foi realizada alinhando o contig contendo o gene $m c r-1$ (173.303 pb) com o scaffold do genoma total, usando BLASTn. Aproximadamente $220.000 \mathrm{pb}$ do plasmídeo foi montado, entretanto devido a presença de inúmeros gaps, esse plasmídeo não foi circularizado. Algumas estratégias como desenhos de primers específicos para estas regiões e alinhamento contra plasmídeos IncHI2 de referência foram realizadas, mas não obtiveram sucesso, uma vez que este plasmídeo apresenta uma nova arquitetura plasmidial.

Além disso, no caso do plasmídeo IncHI2 da cepa CF101, foram testadas três estratégias de reconstrução: (i) o conjunto de scaffold do genoma da cepa CF101 foram 
alinhados contra o esqueleto do plasmídeo IncHI2 da cepa 50H; (ii) o contig contendo o gene mcr-1 (55.324 pb) foi alinhado com o conjunto de scaffold do genoma da cepa CF101; e (iii) o contig contendo o gene mcr-1 (55.324 pb) foi comparado com o banco de dados do GenBank. Não havendo sucesso nas estratégias de montagem do plasmídeo, foi reconstruído 70.334 bp do plasmídeo pCF101, não sendo possível sua circularização.

Durante este estudo, foi identificado em uma cepa produtora CTX-M-8, e uma nova variante de MCR, denominada de $m c r-5.3$. A cepa ECPB39 foi isolada da necropsia pulmonar de um cavalo que morreu por pneumonia no ano de 2012 na cidade de Patos, Paraíba (FERNANDES et al., 2018). A nova variante $m c r-5.3$ diferiu em um aminoácido (Ala414Ser) das variantes $m c r-5$ e $m c r-5.2$, e foi localizada em um plasmídeo não tipável. O plasmídeo pECPB39 que carregava o gene mcr-5.3 não foi capaz de ser transferido pelos ensaios de mobilização, entretanto o plasmídeo IncI1/ST113 que carregava o gene bla $a_{\mathrm{CTX}-\mathrm{M}-8}$ foi transferido para célula receptora E.coli C600 pelo método de conjugação.

A análise do plasmídeo pECPB39 foi realizada in silico, sendo observado que o plasmídeo foi incorporado ao backbone do plasmídeo pKP13a (2459 pb, GenBank CP003996), que continha um gene de mobilização ( $m o b)$ e duas proteínas hipotéticas (DUF) (Figura 15).

Figura 15. Análise comparativa do plasmídeo pECPB39 com o plasmídeo pKP13a

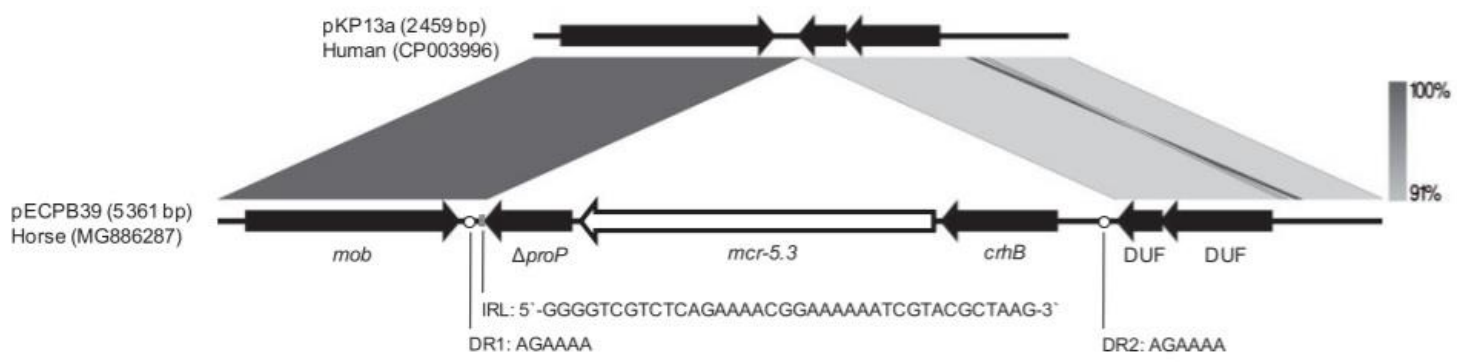

Legenda: Análise da estrutura genética dos plasmídeos pECPB39 (MG886287) e pKP13a (CP003996). O transposon contendo os genes $\Delta$ proP-mcr-5.3-chrB foi incorporado no plasmídeo pKP13a.

Fonte: FERNANDES et al., 2018 
O plasmídeo pECPB39 apresentou o tamanho de $5361 \mathrm{bp}$, diferentemente do plasmídeo pSE13-SA01718 (KY807921) com 17156 bp que carregava a variante mcr-5 e do pEC1066 (MG587003) com 6268 bp que carregava a variante mcr-5.2. Com base nas análises, foi observado que os plasmídeos pSE13-SA01718 e pEC1066 transportavam o mesmo transposon (Tn3), diferentemente dos plasmídeos pECPB39 e pEC0674 que não possuem tnpA e tnpR do transposon do $m c r-5$ (Figura 16).

Figura 16. Análise comparativa dos plasmídeos que carregam o gene $m c r-5$

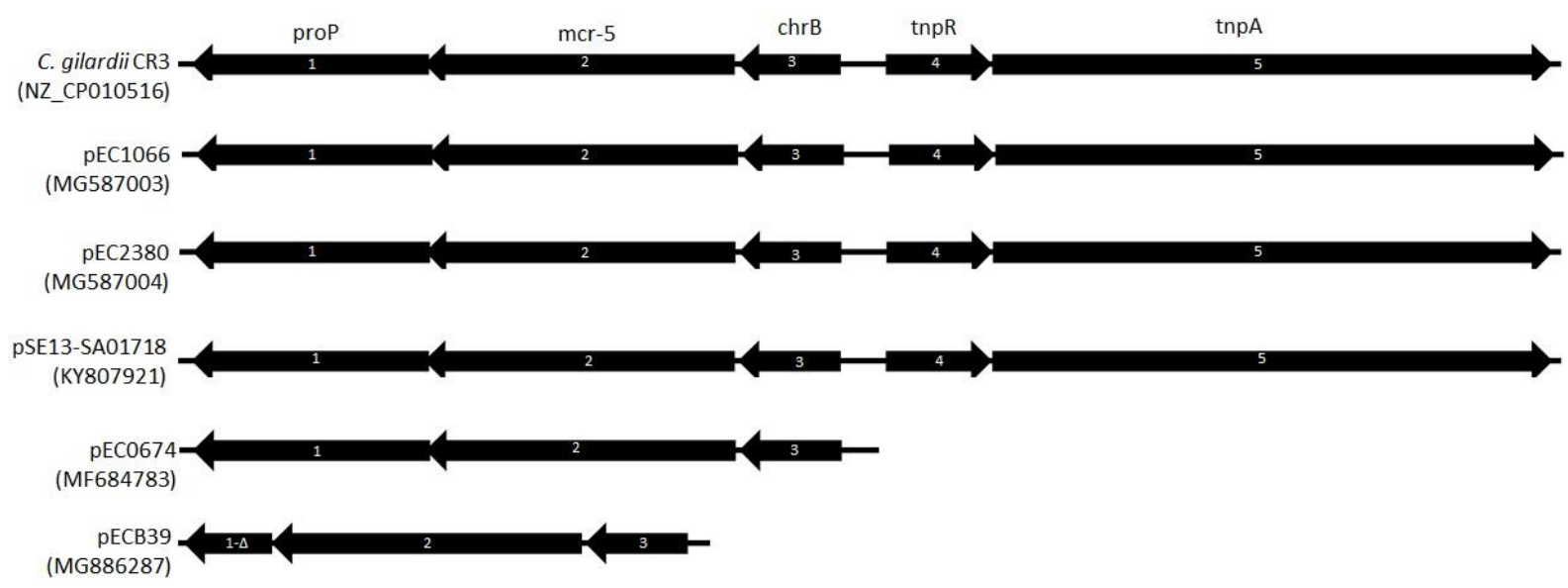

Legenda: A análise comparativa dos plasmídeos revelou que os plasmídeos pSE13-SA01718, pEC1066 e pEC2380 transportam o mesmo tranposon que contém o gene mcr-5. Os plasmídeos pECB39 e pEC0674 não possuem os genes para tnpA e tnpR. Adicionalmente, o plasmídeo pECPB39 apresentou o gene proP truncado.

Fonte: FERNANDES et al., 2018. 


\section{DICUSSÃO}

A rápida evolução e propagação de bactérias resistentes aos antimicrobianos, em paralelo com o desenvolvimento insuficiente de novas drogas, afetam negativamente a terapêutica de infecções bacterianas causadas por MR. A emergência e disseminação de $E$. coli produtora de ESBL do tipo CTX-M é um problema endêmico no Brasil, constituindo uma grande ameaça para o controle de infecções em seres humanos, animais e para a contaminação do meio ambiente. De fato, a resistência relacionada às cefalosporina do tipo CTX-M deixou de ser restrita ao ambiente hospitalar, havendo assim, a disseminação de clones bacterianos de alto risco para diversos ambientes e hospedeiros, e também identificados em alimentos de origem animal e vegetal (CASELLA et al., 2015, LEISTNER et al., 2014; LOPES et al., 2017, SILVA; LINCOPAN et al., 2012; WANG et al., 2014; WARREN et al., 2008).

No Brasil a presença de enzimas do tipo CTX-M tem sido constantemente reportada em espécies de Enterobacteriaceae (AIZAWA et al., 2014; ANDRADE et al., 2014; CARVALHO-ASSEF et al., 2014; CASELLA et al., 2015; DROPA et al., 2015; LEIGUE et al., 2015; FERNANDES et al., 2018, NOGUEIRA et al., 2015; SILVA et al., 2013). Atualmente, as variantes CTX-M-2 e CTX-M-15 são as mais prevalentes no país, seguidas de CTX-M-8, CTX-M-9 e CTX-M-59 (ROCHA et al., 2016).

A variante CTX-M-8 foi identificada pela primeira vez em 1996, em isolados clínicos de E. coli e E. cloacae no Rio de Janeiro, no Brasil (BONNET et al., 2000). Atualmente, esta variante tem sido reportada em animais domésticos e de produção, alimentos e em ambientes aquáticos (AIZAWA et al., 2014; CASELLA et al., 2015; DHANJI et al., 2010; DROPA et al., 2016; FERNANDES et., 2017; KAWAMURA et al., 2014, SACRAMENTO et al., 2018, SILVA et al., 2018).

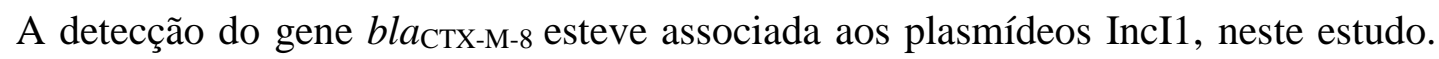
Foram identificados 13 plasmídeos IncI1/ST113 e um plasmídeo pertencente ao ST131 (ICBEC72H). Nas análises dos plasmídeos, observou-se que todos apresentaram o módulo completo de transferência genética (região tra), confirmando, os ensaios in vitro de conjugação. Assim, a ampla gama de hospedeiros e ambientes que esses plasmídeos foram encontrados, poderia ser justificada, pela sua alta capacidade de transferência intra e interespécies, contribuindo com a disseminação dos genes bla $a_{\mathrm{CTX}-\mathrm{M}-8 .}$

Atualmente, os plasmídeos de resistência IncI1 são um dos mais difundidos em $E$. coli, e eles contribuem com a disseminação de genes de ESBLs, em particular do tipo CTX-M em diversos ambientes e hospedeiros (POIREL et al., 2018). 
É importante ressaltar, que nesse estudo a distribuição dos plasmídeos IncI1/ST113 no Brasil, está relacionada entre diferentes períodos de isolamento (2009 e 2016) e, principalmente, em diferentes origens (animal de produção, animal de companhia, esgoto e água do mar), ressalta o poder de ubiquidade destes plasmídeos. Adicionalmente, esses plasmídeos foram identificados em animais domésticos (p56AC1, pECPB17 e pECPB39), selvagens (pAJ6, pAJ7, pC6O e pS13.2) e de produção (pICBEC12-3F e pFP39-2), alertando as diferentes fontes de disseminação e o grau de estabilidade desses plasmídeos em animais de diferentes comportamentos e habitats.

No Brasil, foi reportado a ocorrência de bla $a_{\mathrm{CTX}-\mathrm{M}-8}$ e bla $a_{\mathrm{CTX}-\mathrm{M}-2}$ em isolados de Salmonella spp. recuperados de amostras de carne de frango e peru, e que estavam localizados em plasmídeos do tipo IncI1/ST113 (MOURA et al., 2017a). Interessantemente, plasmídeos

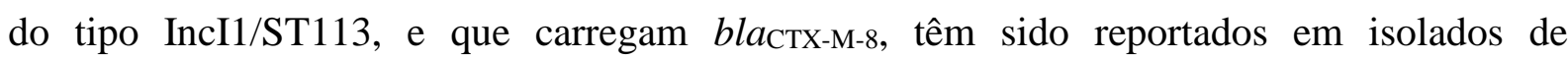
Enterobacteriaceae em amostras clínicas de humanos, animais de produção, em amostras de carne de frango em outros países como Alemanha, Japão, Espanha, Guiana Francesa, e Tunísia (AIZAWA et al., 2014; BONNET et al., 2000; DROPA et al., 2016; ELLER et al., 2014; FERREIRA et al., 2014; KIIRU et al., 2012; JOUINI et al., 2013; MONTE et al., 2017; MOURA et al., 2017a; VINUE et al., 2009; Woerther et al., 2013), o que mostra que essa variante não está mais confinada à América do Sul e que pode se tornar endêmica. Algumas hipóteses levam a acreditar que a presença de $b a_{\mathrm{CTX}-\mathrm{M}-8}$ em outros países, seria devido a exportação de carne de frango, uma vez que o Brasil é o segundo maior exportador desses

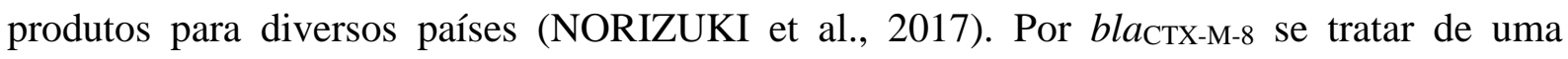
variante brasileira, ainda existem poucos estudos relacionados ao sequenciamento desses plasmídeos, o que dificulta uma análise de ancestralidade profunda desses plasmídeos.

A arquitetura dos plasmídeos IncI1 - ST113 e ST131, apresentou-se conservada em todos os plasmídeos estudados, sendo dividido em regiões de replicação (repY), estabilidade (parA, parB, kor, ibfa) $e$ transferência (traA-Y).

Não foram encontrados adicionais genes de resistência, além do bla $a_{\text {CTX-M-8. }}$ O

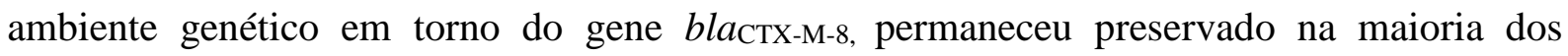

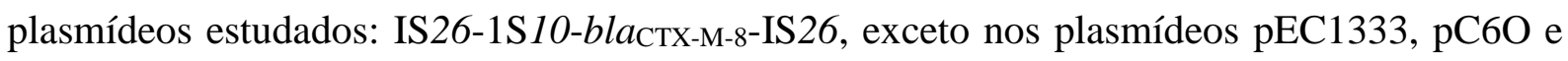
pS13.2, onde a IS26 permaneceu apenas upstream ao gene.

A análise comparativa dos plasmídeos deste estudo com diferentes plasmídeos IncI1,

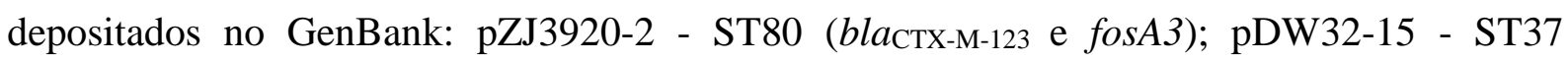

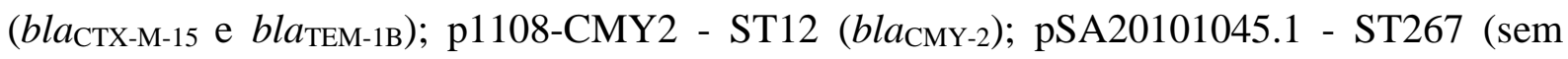
genes de resistência); pSa21-TC-CIP - ST162 (qnrS, aph(6)-Id, aph(3”)-Ib e tetC), mostrou 
que eles apresentaram $80 \%$ de sua arquitetura conservada (incluindo regiões de replicação, estabilidade e transferência), independente do ST plasmidial e da ausência e/ou presença de genes de resistência. Adicionalmente, os pICBEC72H, pFP39-2, pEC1333, pHECO1, pICBEC7AM, p56AC1, pECPB17, pICBEC12-3F exibiram entre 96-98\% de identidade com o plasmídeo R64, considerado o protótipo do grupo IncI1/ST13.

$\mathrm{Na}$ análise filogenética foi observada a formação de dois grandes clusters (I e II). O cluster I, apresentou mais ramificações, e foi agrupado em dois subgrupos (Ia e Ib). O subgrupo Ia apresentou o agrupamento de 13 plasmídeos de diferentes STs, sem distinção de origem de isolamento, país e presença e/ou ausência de genes de resistência. Os três plasmídeos deste estudo, foram agrupados neste subgrupo, juntamente com o plasmídeo brasileiro p2964TF. No subgrupo Ib o plasmídeo ambiental pCMY-1225 não apresentou agrupamento com nenhum outro plasmídeo. No cluster II, houve agrupamento de dois plasmídeos de origem humana e um animal, de distintos STs: ST12, ST16 e ST80. Entretanto, nesta análise filogenética não houve a formação de clones, nem mesmo entre os plasmídeos pertencentes ao mesmo ST ou que carregavam o mesmo gene de resistência.

Neste estudo plasmídeos epidêmicos IncI1 foram identificados em diferentes origens, entretanto, ainda não está claro o que poderia favorecer o sucesso de disseminação desses plasmídeos, além da sua alta taxa de transferência. A disseminação mundial de plasmídeos IncI1 não pode ser explicada simplesmente pela seleção exercida por drogas antimicrobianas (CARATTOLI et al., 2018).

O uso exacerbado de cefalosporinas de terceira geração, tem contribuído com a disseminação de genes de ESBLs, mais especificamente $b_{\text {CTX-M, }}$, resultando na utilização dos carbapenêmicos no tratamento das infecções ocasionadas (BUSH; JACOBY, 2010; CARATTOLI, 2013; HARRIS et al., 2015). Entretanto, com a utilização excessiva, surgiram as carbapenemases mediadas por plasmídeos, principalmente bla $a_{\mathrm{KPC}}$ e bla $a_{\mathrm{NDM}}$. Atualmente, $K$. pneumoniae produtora de KPC, está amplamente disseminada em vários continentes, causando diversos surtos (MATHERS et al., 2015). Assim, o antimicrobiano de escolha no tratamento de infecções causada por bactérias produtoras de carbapenamse, é a polimixina (NORDMANN et al., 2011).

No ano de 2015, foi identificado em animais de produção, um mecanismo de resistência transferível à polimixina, codificado pelo gene mcr-1. Infelizmente, embora as polimixinas B e E tenham sido sintetizadas em meados dos anos 40, ainda são considerados os antibióticos de última escolha terapêutica para o tratamento de infecções por ESBLs e carbapenemases (LIU et al., 2015), o que reforça a necessidade de estudos envolvendo a 
dinâmica de transmissão deste gene. Até o presente momento, O MCR-1 tem sido encontrado em diferentes espécies de Enterobacteriaceae, tais como Salmonella spp., Klebsiella spp., Enterobacter spp. e Kluyvera spp., (HU et al., 2016; OLAITAN et al., 2016; QUESADA et al., 2016; ZHAO et al., 2016),entretanto tem sido predominante em E. coli devido a sua grande versatilidade, o que provavelmente pode estar relacionado a eventos genéticos que contribuem com a mobilização deste gene entre linhagens diferentes (FALGENHAUER et al., 2016; VASQUEZ et al., 2016; VADING et al., 2016; WANG et al., 2017).

Diferentes grupos de incompatibilidade em plasmídeos são encontrados carreando o gene $m c r-1$, sendo eles: IncI2, IncX4, IncHI1, IncHI2, IncF, IncFI, IncFII, IncP e ColE. Os plasmídeos do tipo IncX4 encontram-se em situação pandêmica, sendo reportados em diversos continentes, incluindo o Brasil. É digno de nota que a disseminação plasmidial de IncX4 demonstra alta identidade (>98\%) entre os plasmídeos de $m c r-1$ do Brasil e do mundo (BRAUER et al., 2016; Di PILATO,2016; DOUMITH et al., 2016; FERNANDES et al., 2016b; POIREL et al., 2016; ZURFLUH et al., 2016; XAVIER et al., 2016).

Neste estudo, os plasmídeos IncX4 foram identificados em diferentes origens. Cinco plasmídeos puderam ser transferidos em ensaios de conjugação, e tiveram o tamanho de $33 \mathrm{~kb}$. Adicionalmente, não foram encontrados genes adicionais de resistência nesses plasmídeos.

Os plasmídeos da família IncX são amplamente encontrados em espécies de Enterobacteriaceae e são atualmente divididos em seis subtipos (Incx1-IncX6), os quais compartilham grande similaridade genética em sua arquitetura (JOHNSON et al., 2012). A arquitetura desse grupo plasmidial, inclui genes essenciais como: pir-bis-par-hns-topB-pilXact X-tax $C A$, os quais são responsáveis pela replicação (pir e bis), síntese e montagem do pilus (pilX), conjugação (taxAC) e funções de manutenção/ estabilidade do plasmídeo (hns e par) (BUSTAMANTE; IREDELL, 2017).

O primeiro IncX R6K isolado de Salmonella spp. foi reportado na era pré-antibiótica em 1917, e mais tarde foi subtipado no grupo IncX2 (DATTA; HUGHES, 1983; JONES;STANLEY, 1992). Atualmente podemos encontrar plasmídeos do tipo IncX carregando uma variedade de genes de resistência de diferentes classes de antibióticos como: $q n r B, q n r S, b l a_{\mathrm{CTX}-\mathrm{M}-14}, b l a_{\mathrm{CTX}-\mathrm{M}-15}, b_{\mathrm{KPC}}$ e $b l a_{\mathrm{NDM}}$. Entretanto, nos últimos anos plasmídeos do tipo IncX4 tem sido reportado como um dos principais vetores de disseminação do gene mcr-1 em diversos países (CERDEIRA et al., 2017; DOBIASOVA; DOLEJSKA, 2016; ESPINAL et al., 2017; SHEN et al., 2017). 
Independentemente da origem de isolamento, todos os plasmídeos IncX4 apresentaram sua arquitetura altamente conservada. Genes essenciais pir, taxC, parA e hns foram encontrados em todos os plasmídeos deste estudo (FERNANDES et al., 2016; FERNANDES et al., 2017; MONTE et al., 2017; SELLERA et al., 2016). De acordo com a classificação, os genes $\operatorname{tax} C$ de diferentes grupos de incompatibilidade compartilham entre $37 \%$ e $92 \%$ de identidade de nucleotídeos, enquanto que aqueles de um mesmo subgrupo de incompatibilidade compartilham entre $92 \%$ e $99 \%$ de identidade de nucleotídeos (JOHNSON et al., 2012). Os plasmídeos deste estudo apresentaram 99\% de identidade entre si, e 98-99\% com outros plasmídeos do mesmo grupo de incompatibilidade depositados no GenBank.

Dentre os 25 plasmídeos IncX4 carregando mcr-1 depositados no Genbank todos compartilham entre 95-99,9\% de identidade, exceto pKP37-BE (LT598652) e pCQO2-121 (KU647721) reportados na Bélgica e na China (SUN et al., 2016; XAVIER et al., 2017). O plasmídeo pKP37-BE corresponde a nova variante $m c r-2$ isolada em amostras de suínos em E. coli, e apresentam aproximadamente $85 \%$ de similaridade com os plasmídeos brasileiros. O plasmídeo pCQO2-121 isolado de amostra clínica de felino em E. coli foi derivado da recombinação entre dois subgrupos dos plasmídeos IncX (X3-X4), o qual foi co-produtor de MCR-1 e NDM-5, esses plasmídeos compartilham de 75-85\% de identidade com os plasmídeos deste estudo.

No plasmídeo pICBEC72Hmcr isolado de uma infecção humana foi observado a similaridade de 99,9\% com outros plasmídeos IncX4 encontrados na Estônia e na China, e com 95,2\% de identidade com o plasmídeo da África do Sul (FERNANDES et al., 2016b), esses dados corroboram com a disseminação global dos plasmídeos IncX4.

Interessantemente o plasmídeo (pICBEC7P) isolado de uma infecção conhecida como pododermatite em pinguim causada por E. coli ST10 no ano de 2013 em Santos no litoral de São Paulo, não foi capaz de ser transferido nos ensaios de conjugação. Após o sequenciamento e montagem desses plasmídeos, foi observado a presença de um elemento de inserção (IS1294) até o momento ainda não descrito em outros plasmídeos IncX4, truncando o gene de mobilização mobA o que poderia justificar a incapacidade de mobilização desse plasmídeo (SELLERA et al., 2016). Adicionalmente três anos após, foi isolado em outra $E$. coli ST10 de amostra marinha na mesma praia, onde os animais marinhos são resgatados, o mesmo plasmídeo carregando mcr-1. Os plasmídeos pICBEC7P e pICBEC13AM compartilharam > 99\% de identidade genética, com a presença do mesmo elemento de inserção IS1294, consequentemente o link epedimiológico entre a cepa do pinguim e a amostra marinha puderam ser elucidadas (FERNANDES et al., 2017; SELLERA et al.,2016). 
Em relação a filogenia dos plasmídeos IncX4, foram agrupados em dois clusters, independentemente da origem e região geográfica, em que foi identificado. No cluster I, nove plasmídeos, incluindo os deste estudo (pICBEC72H, pICBEC7P, pICBEC3AM e pICBEC13AM) foram agrupados juntamente com plasmídeos identificados na França, Bélgica e China. Os plasmídeos pICBEC72H, pICBEC7Pe pICBEC3AM. Os plasmídeos com genes de resistência às cefalosporinas (bla $a_{\mathrm{CTX}-\mathrm{M}-14} \mathrm{e}$ bla $a_{\mathrm{CTX}-\mathrm{M}-15)}$ ) permaneceram no mesmo grupo dos plasmídeos com o gene $m c r-1$.

O cluster II, seis plasmídeos foram agrupados, sendo que dois clados apresentaram os plasmídeos pCSZ4 (China) e pMCRpoa (Brasil) tiveram 100\% de identidade nucleotídica. Dentro deste cluster, foram agrupados os plasmídeos com genes de resistência bla $a_{\text {CTX-M-14 e }}$

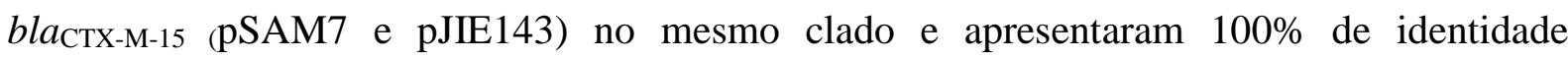
nucleotídica. Após a construção da filogenia, foi realizado um alinhamento no MAUVE, com os plasmídeos representativos de cada cluster. Assim, foi observado o alto grau de conservação entre os plasmídeos IncX4, com pequenas variações relacionadas a presença ou ausência de genes putativos. Sendo assim, o sucesso da disseminação do gene $m c r-1$ através de plasmídeos IncX4, poderia estar associada a características particulares deste grupo plasmídial, como estabilidade, persistência e sucesso adaptativo em seus hospedeiros bacterianos.

Neste estudo, a identificação da nova variante $m c r-5.3$ em um cavalo infectado por $E$. coli coprodutora de CTX-M-8 no ano de 2012, que não recebeu tratamento com colistina anteriormente, sugere a presença do gene mcr-5.3 no Brasil, há pelo menos 7 anos, destacando a necessidade do monitoramento e uso consciente de antimicrobianos na medicina veterinária (FERNANDES et al., 2018d). Inicialmente, o gene $m c r-5$ foi identificado em uma cepa de Salmonella Paratyphi isolada de carne de frango no ano de 2011, na Alemanha (BOROWIAK et al., 2017). Em seguida, foi identificada a variante $m c r-5.2 \mathrm{em}$ E. coli isolada de animais de produção (HAMMERL et al., 2017).

A nova variante $m c r-5.3$ diferiu em um aminoácido (Ala414Ser) das variantes $m c r-5$ e mcr-5.2, e foi localizada em um plasmídeo não tipável. O plasmídeo pECPB39 que carregava o gene mcr-5.3 não foi capaz de ser transferido pelos ensaios de mobilização, entretanto o plasmídeo IncI1/ST113 que carregava o gene $b l a_{\mathrm{CTX}-\mathrm{M}-8}$ foi transferido para célula receptora E.coli C600 pelo método de conjugação.

A análise do plasmídeo pECPB39 foi realizada in silico, sendo observado que o plasmídeo foi incorporado ao backbone do plasmídeo pKP13a que continha um gene de mobilização $(m o b)$ e duas proteínas hipotéticas (DUF). 
Interessantemente, foi identificado plasmídeos do grupo IncHI2, portadores do gene mcr-1, em isolados de carne de frango e em seres humanos, pela primeira vez, no Brasil. Plasmídeos conjugativos do grupo incompatibilidade $\mathrm{H}(\mathrm{IncH})$ são divididos em dois grandes grupos, IncHI1 e IncHI2. Os plasmídeos da família HI2 são plasmídeos de ampla gama de hospedeiros e frequentemente carregam genes de resistência clinicamente significantes, como genes codificadores de $\beta$-lactamases de espectro estendido (ESBLs) (bla $a_{\text {CTX-M), genes }}$ resistentes a quinolona (PMQR) plasmídeos $(o q x A B)$, carbapenemase genes (bla $a_{\mathrm{IMP}}$, bla $\mathrm{vIM}$ e bla $\left.a_{\mathrm{NDM}}\right)$ e gene de resistência à colistina mediada por plasmídeo ( $\left.m c r-1\right)$ (CAIN \& HALL, 2012; GARCIA-FERNANDEZ \& CARATTOLI, 2010).

Plasmídeos da família IncHI2 tem sido considerado o terceiro grupo mais frequentemente associado à disseminação mundial do gene $m c r-1$, após os plasmídeos IncI2 e IncX4 (MATAMOROS et al., 2017; GIRLANE et al., 2017; GRAMI et al., 2016; HADJADJ et al., 2017; KIEFFER et al., 2017).

Em geral, a disseminação do gene $m c r-1$ pelos plasmídeos IncHI2, não está relacionado a um DMLST específico. Particularmente, os dois plasmídeos relatados neste estudo pertenciam a ST4, bem como descrito em cepas de E. coli isoladas de fazendas na França e na Tunísia, e de viajantes em Laos (GRAMI et al., 2016; HADJADJ et al., 2017). Curiosamente, embora plasmídeos HI2 deste estudo pertençam ao mesmo ST, eles não estão relacionados a uma arquitetura conservada esqueleto, uma vez que apresentaram diferentes elementos móveis (integrons e sequências de inserção) e genes de resistência, como parte da recombinação genética.

Os plasmídeos IncHI2 são termossensíveis em sua transferência, sendo a temperatura ótima para expressão do pilus entre 22-30 ${ }^{\circ} \mathrm{C}$ (TAYLOR \& LEVINE, 1980). Os plasmídeos pC2550H e pC25101 foram termossensíveis, uma vez que a transferência foi bem-sucedida a $25^{\circ} \mathrm{C}$, enquanto nenhuma transferência foi observada a $37^{\circ} \mathrm{C}$. Assim, foi confirmado que o

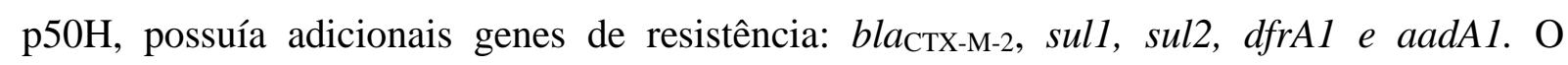
tamanho de ambos os plasmídeos IncHI2, foi de $\sim 200 \mathrm{~kb}$.

Infelizmente devido ao tamanho e a complexidade dos plasmídeos IncHI2, não foi possível realizar a circularização desses plasmídeos. Algumas estratégias como desenhos de primers específicos para estas regiões e alinhamento contra plasmídeos IncHI2 de referência foram realizadas, mas não obtiveram sucesso, uma vez que este plasmídeo apresenta uma nova arquitetura plasmidial. 
Sendo assim, a caracterização molecular dos plasmídeos de E. coli que carregam bla $a_{\text {CTX-M-8 }}$ e $m c r-1$ deste estudo, mostrou que plasmídeos de diferentes ecossistemas podem apresentar condições homólogas em sua arquitetura como: grupo de incompatibilidade, região de estabilidade e transferência, assim como resistoma.

Técnica moleculares de tipagem bacteriana, classificação dos grupos de incompatibilidade plasmideal, pMLST, análises do genoma bacteriano e o sequenciamento plasmidial fornecem dados epidemiológicos relevantes para a compreensão da dinâmica da transmissão de genes de resistência mediada por plasmídeos. A análise filogenética dos plasmídeos IncI1 e IncX4, destacam que ambos compartilham uma arquitetura conservada, e a evolução pode estar atribuída à aquisição de determinantes de resistência antimicrobiana clinicamente relevantes. O monitoramento de plasmídeos de resistência, contribui com o esclarecimento epidemiológico de rotas pelas quais a resistência bacteriana surge, assim como apoia o conceito da disseminação de genes de resistência em diferentes reservatórios animais e ambientais (CARATTOLI et al., 2018).

Assim, estudos que visam investigar aspectos relacionados à relação ancestral e panresistoma plasmidial podem fornecer uma base científica para monitorar e elucidar a rota epidemiológica e possíveis fontes de aquisição de genes de resistência. Portanto, as aplicações de ferramentas moleculares e de bioinformática podem ter uma contribuição prática, baseada na identificação da origem e dos veículos de disseminação dos genes de resistência, o que poderia ser aplicado para ter um controle efetivo e estabelecer políticas de vigilância epidemiológica. 


\section{CONCLUSÕES}

- Foi mostrado neste estudo a versatilidade genética de cepas de E. coli, carregando importantes genes de resistência em diferentes ambientes e hospedeiros;

- A presença da variante brasileira CTX-M-8 tem sido amplamente disseminada pelo país, e até o momento, os plasmídeos IncI1, são os principais vetores dessa disseminação;

- Os primeiros relatos do gene $m c r-1$ no Brasil, identificado em diferentes origens, foi relatado neste trabalho;

- Os plasmídeos IncX4 foram considerados os principais veículos de disseminação do gene $m c r-1$ no Brasil;

- A presença de plasmídeos IncHI2 como novos potenciais vetores na disseminação do gene $m c r-1$ no Brasil;

- A identificação de uma nova variante, denominada de $m c r-5.3$ em um plasmídeo não tipavel, isolado de uma secreção pulmonar de cavalo, reforça ainda mais o problema da resistência bacteriana em diferentes hospedeiros;

- A análise filogenética dos plasmídeos IncI1 e IncX4, destacam que ambos compartilham uma arquitetura conservada, e a evolução é atribuída à aquisição de determinantes de resistência antimicrobiana clinicamente relevantes.

- Os resultados desse estudo demonstram o grave problema da resistência bacteriana dentro do conceito one-health, e que com o avanço de ferramentas moleculares a identificação e resolução desse problema poderá estar cada vez mais próxima de ser elucidada. 


\section{REFERÊNCIAS BIBLIOGRÁFICAS}

1.ABUOUN, M., STUBBERFIELD, E.J., DUGGETT, N.A., KIRCHNER, M., DORMER, L., NUNEZ-GARCIA, J., RANDALL, L.P., LEMMA, F., CROOK, D.W., TEALE, C., SMITH, R.P., ANJUM, M.F. $m c r-1$ and $m c r-2$ (mcr-6.1) variant genes identified in Moraxella species isolated from pigs in Great Britain from 2014 to 2015. J Antimicrob Chemother., v.73, p. 2904, 2018.

2.AIRES, C.A.M., DA CONCEIÇÃO-NETO, O.C., TAVARES, E., OLIVEIRA, T.R., DIAS, C.F., MONTEZZI, L.F., PICÃO, R.C., ALBANO, R.M., ASENSI, M.D., CARVALHOASSEF, A.P.D. Emergence of the Plasmid-Mediated $m c r-1$ Gene in Clinical KPC-2Producing Klebsiella pneumoniae Sequence Type 392 in Brazil. Antimicrob. Agents Chemother. v.61, pii: e00317-17, 2017.

3.AIZAWA, J., NEUWIRT, N., BARBATO, L., NEVES, P.R., LEIGUE, L., PADILHA, J., PESTANA, D.E., CASTRO, A.F., GREGORY, L., LINCOPAN, N. Identification of fluoroquinolone-resistant extended-spectrum $\beta$-lactamase (CTX-M-8) -producing Escherichia coli ST224, ST2179 and ST2308 in buffalo (Bubalus bubalis). J. Antimicrob. Chemother., v. 69, p. 2866-2869, 2014.

4.AL-KANDARI, F., WOODWARD, M.J. Genotypic and phenotypic diversity differences of presumptive commensal and avian pathogenic E. coli. Br Poult Sci., v.60, p.79-86, 2019.

5.ALTERI, C. J., MOBLEY, H.L. Escherichia coli physiology and metabolism dictates adaptation to diverse host microenvironments. Curr. Opin. Microbiol., v. 15, p. 3-9, 2012.

6.AMINOV, R.I. A brief history of the antibiotic era: lessons learned and challenges for the future. Front. Microbiol. v.134, p.1-7, 2010.

7.ANAGO, E. AYI-FANOU, L., AKPOVI, C. D., HOUNKPE, W. B., AGASSOUNONDJIKPO TCHIBOZO, M., BANKOLE, H. S., \& SANNI, A. Antibiotic resistance and genotype of beta-lactamase producing Escherichia coli in nosocomial infections in Cotonou, Benin. Annals of Clin. Microbiol. Antimicrob., v.14, 2015.

8.ANDRADE, L.N., VITALI, L., GASPAR, G.G., BELLISSIMO-RODRIGUES, F., MARTINEZ, R., DARINI, A.L. Expansion and evolution of a virulent, extensively drugresistant (polymyxin B-resistant), QnrS1-, CTX-M-2-, and KPC-2-producing Klebsiella pneumoniae ST11 international high-risk clone. J. Clin. Microbiol., v. 52, p. 2530-2535, 2014.

9.AGÊNCIA NACIONAL DE VIGILÂNCIA SANITÁRIA: ANVISA. Boletim de Segurança do Paciente e Qualidade em Serviços de Saúde nº 14: Avaliação dos indicadores nacionais das Infecções Relacionadas à Assistência à Saúde (IRAS) e Resistência microbiana do ano de 2015. 2016.

10.ARENAS-HERNÁNDEZ, M.M., MARTÍNEZ-LAGUNA, Y., TORRES, A.G. Clinical Implications of Enteroadherent Escherichia coli. Curr. Gastroenterol. Rep., v. 14, p. 386394, 2012.

11.ASLAM, B., WANG, W., ARSHAD, M.I., KHURSHID, M., MUZAMMIL, S., 
RASOOL, M.H., NISAR, M.A., ALVI, R.F., ASLAM, M.A., QAMAR, M.U., SALAMAT, M.K.F., BALOCH, Z. Antibiotic resistance: a rundown of a global crisis. Infect. Drug Resist., v. 11, p.1645-1658, 2018.

12.ASOKAN, G.V. One Health and Zoonoses: The Evolution of One Health and Incorporation of Zoonoses. Cent. Asian J. Glob. Health, v.4, p.139, 2015.

13.BAIN, R., CRONK, R., HOSSAIN, R., BONJOUR, S., ONDA, K., WRIGHT, J., YANG, H., SLAYMAKER, T., HUNTER, P., PRÜSS-USTÜN, A., BARTRAM, J. Global assessment of exposure to faecal contamination through drinking water based on a systematic review. Trop. Med. Int. Health., v. 19, p. 917-927, 2014.

14.BALSAlOBRE, L. C., DROPA, M., MATTÉ, M.H. An overview of antimicrobial resistance and its public health significance. Braz. J. Microbiol., v.45, p.1-5, 2014.

15.BARDAK-OZCEM, S., SIPAHI, O.R. An updated approach to healthcareassociated meningitis. Expert. Ver. Anti. Infect. Ther., v. 12, p. 333-342, 2014.

16.BARTON, B. M.; HARDING, G.P.; ZUCCARELLI, A.J. A general method for detecting and sizing large plasmids. Analytical biochem., v. 226, p. 235-240, 1995.

17.BAUERNFEIND, A., GRIMM, H., SCHWEIGHART, S. A new plasmidic cefptaximase in a clinical isolate of Escherichia coli. Infection, v. 8, p. 294-298, 1990.

18.BAXTER, J.C., FUNNELL, B.E. Plasmid partition mechanisms. Microbiol. Spectr. v. 2, p. PLAS-0023, 2014.

19.BELAS, A. et al. Risk factors for faecal colonization with E. coli producing extend spectrum and plasmid-mediated AmpC $\beta$-lactamases in dogs. Vet. Rec., v. 175, p. 202, 2014.

20.BERENDONK, T.U., MANAIA, C.M., MERLIN, C., FATTA-KASSINOS, D, CYTRYN, E., WALSH, F., BÜRGMANN, H., SORUM, H., NORSTRÖM, M., PONS, M.N., KREUZINGER, N., HUOVINEN, P., STEFANI, S., SCHWARTZ, T., KISAND, V., BAQUERO, F., MARTINEZ, J.L. Tackling antibiotic resistance: the environmental framework. Nat. Rev. Microbiol., v. 13, p. 310-7, 2015.

21.BEVAN, E.R., JONES, A.M., HAWKEY, P.M. Global epidemiology of CTX-M $\beta$ lactamases:temporal and geographical shifts in genotype. J Antimicrob Chemother. v. 72, p. 2145-2155, 2017

22.BIRNBOIM, H. C; DOLY, J. A. rapid alkaline extraction procedure for screening recombinant plasmid DNA. Nucleic Acids Res., v. 7, p. 1513-1523, 1979.

23.BLAIR, J. M, et al. Molecular mechanisms of antibiotic resistance. Nat Rev Microbiol. v.13, p. 42-51, 2015.

24.BLEICHER, A., SCHÖFL, G., RODICIO MDEL, R., SALUZ, H.P The plasmidome of a Salmonella enterica serovar Derby isolated from pork meat. Plasmid, v. 69, p. 202-210, 2013. 
25.BONNET, R, et al. A novel CTX-M beta-lactamase (CTX-M-8) in cefotaxime-resistant Enterobacteriaceae isolated in Brazil. Antimicrob Agents Chemother., v. 44, p. 1936-42, 2000.

26.BOROWIAK, M., FISCHER, J., HAMMERL, J.A., HENDRIKSEN, R.S, SZABO, I., MALORNY, B. Identification of a novel transposon-associated phosphoethanolamine transferase gene, mcr-5, conferring colistin resistance in d-tartrate fermenting Salmonella enterica subsp. enterica serovar Paratyphi B. J. Antimicrob. Chemother., v. 72, p.3317-3324, 2017.

27.BOTELHO, L.A.B., KRAYCHETE, G.B., COSTA E SILVA, J.L., REGIS, D.V., PICÃO, R.C., MOREIRA, B.M., BONELLI, R.R. Widespread distribution of CTX-M and plasmidmediated AmpC $\beta$-lactamases in Escherichia coli from Brazilian chicken meat. Mem. Inst. Oswaldro Cruz, v. 110, p. 249-254, 2015.

28.BRAUN, G., CAYÔ, R., MATOS, A.P., DE MELlO FOnSECA, J., GALES, A.C. Temporal evolution of polymyxin B-resistant Klebsiella pneumoniae clones recovered from blood cultures in a teaching hospital during a 7-year period. Int J Antimicrob Agents. v.51, p.522-527, 2018.

29.BROLOUND, A. Overview of ESBL-producing Enterobacteriaceae from a Nordic perspective. Infect. Ecol. Epidemiol., v. 4, 2014.

30.BROWN, E.D., WRIGHT, G.D. Antibacterial drug discovery in the resistance era. Nature, v. 529, p.336-43, 2016.

31.BROUWER, M.S.M., JURBURG, S.D., HARDERS, F., KANT, A., MEVIUS, D.J., ROBERTS, A.P., BOSSERS, A. The shufflon of IncI1 plasmids is rearranged constantly during different growth conditions. Plasmid. v.102, p.51-55, 2019

32.BUENO, M.F., FRANCISCO, G.R., O'HARA, J.A., DE OLIVEIRA GARCIA, D., DOI, Y. Coproduction of $16 \mathrm{~S}$ rRNA methyltransferase RmtD or RmtG with KPC-2 and CTX-M group extended-spectrum $\beta$-lactamases in Klebsiella pneumoniae. Antimicrob. Agents Chemother., v. 57, p. 2397-2400, 2013.

33.BUSH, K; JACOBY, G. A. Updated functional classification of beta-lactamases. Antimicrob. Agents Chemother., v. 54, p. 969-976, 2010.

34.BUSTAMANTE, P, IREDELL, J.R. Carriage of type II toxin-antitoxin systems by the growing group of IncX plasmids. Plasmid, v. 9, p.119-27, 2017.

34.CABRAL, A.B., MELO, R.C.A, MACIEL, M.A.V., LOPES, A.C.S. Multidrug resistance genes, including bla $\mathrm{KPC}_{\mathrm{C}}$ and bla $a_{\mathrm{CTX}-\mathrm{M}-2}$ among Klebsiella pneumoniae isolated in Recife, Brazil. Rev. Soc. Bras. Med .Trop., v. 45, p. 572-578, 2012.

35.CAMPANA, E.H., XAVIER, D.E., PETROLINI, F.V., CORDEIRO-MOURA, J.R., ARAUJO, M.R., GALES, A.C. Carbapenem-resistant and cephalosporin-susceptible: a worrisome phenotype among Pseudomonas aeruginosa clinical isolates in Brazil. Braz $\boldsymbol{J}$ Infect Dis., v.21, p.57-62, 2017. 
36.CANTÓN, R., GONZÁLEZ-ALBA, J.M., GALÁN, J.C. CTX-M enzymes: origin and diffusion. Front. Micrbiol., v.3, p. 1-19, 2012.

37.CARATTOLI, A., BERTINI, A., VILlA, L., FALBO, V., HOPKINS, K.L., THRELFALL, E.J. Identification plasmidis by PCR- based replicon typing. J. Microbiol. Methods, v.63, p. 2227-2238, 2005.

38.CARATTOLI, A. Resistance plasmids families Enterobacteriaceae. Antimicrob. Agents and Chemother., v. 53, p. 2227-2238, 2009.

39.CARATTOLI, A. Plasmids and the spread of resistance. Inter. J. Medical Microbiol., v. 303, p. 298- 304, 2013.

40.CARATTOLI, A., ZANKARI, E., GARCÍA-FERNÁNDEZ, A., VOLDBY LARSEN, M., LUND, O., VILLA, L., MØLLER AARESTRUP, F., HASMAN, H. In silico detection and typing of plasmids using PlasmidFinder and plasmid multilocus sequence typing. Antimicrob Agents Chemother. v. 58, p. 3895-903, 2014.

41.CARATTOLI, A, et al. Novel plasmid-mediated colistin resistance $m c r-4$ gene in Salmonella and Escherichia coli, Italy 2013, Spain and Belgium, 2015 to 2016. Eurosurveillance, 2017.

42.CARATTOLI, A., VILLA, L., FORTINI, D., GARCÍA-FERNÁNDEZ, A. Contemporary IncI1 plasmids involved in the transmission and spread of antimicrobial resistance in Enterobacteriaceae. Plasmid, pii: S0147-619X(18)30046-5, 2018.

43.CARROLL, D., WANG, J., FANNING, S., MCMAHON, BJ. Antimicrobial Resistance in Wildlife: Implications for Public Health. Zoonoses Public Health, v. 62, p. 534-42, 2015.

44.CARROLL, L.M., GABALLA, A., GULDIMANN, C., SULLIVAN, G., HENDERSON, L.O., WIEDMANN, M. Identification of Novel Mobilized Colistin Resistance Gene mcr-9 in a Multidrug-Resistant, Colistin-Susceptible Salmonella enterica Serotype Typhimurium Isolate. MBio, v. 10(3), 2019.

45.CARVALHO-ASSEF, A.P., PEREIRA, P.S., ALBANO, R.M., BERIÃO, G.C., TAVARES, C.P., CHAGAS, T.P., MARQUES, E.A., TIMM, L.N., DA SILVA, R.C., FALCI, D.R., ASENSI, M.D. Detection of NDM-1-, CTX-M-15-, and qnrB4-producing Enterobacter hormaechei isolates in Brazil. Antimicrob. Agents Chemother., v. 58, p. 24752476, 2014.

46.CASELLA, T., RODRÍGUEZ, M.M., TAKAHASHI, J.T., GHIGLIONE， B., DROPA, M., ASSUNÇÃO, E., NOGUEIRA, M.L., LINCOPAN, N., GUTKIND, G., NOGUEIRA,

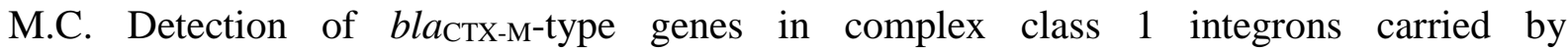
Enterobacteriaceae isolated from retail chicken meat in Brazil. Int. J. Food Microbiol., v. 197, p. 88- 91, 2015.

47.CASTELLANOS, L.R., DONADO-GODOY, P., LEÓN, M., CLAVIJO, V., AREVALO, A., BERNAL, J.F.,TIMMERMAN, A.J., MEVIUS, D.J., WAGENAAR, J.A., HORDIJK, J. High Heterogeneity of Escherichia coli Sequence Types Harbouring ESBL/AmpC Genes on IncI1 Plasmids in the Colombian Poultry Chain. PLoS One. v. 12, p.e0170777, 2017. 
48.CENTERS FOR DISEASE CONTROL AND PREVENTION - CDC. Antibiotic/Antimicrobial resistance. Biggest Threats and Data, 2018 [acesso em 11 de março de 2019], (https://www.cdc.gov).

49.CERDEIRA, L. T, et al. Rapid hybrid de novo assembly of a microbial genome using only short reads: Corynebacterium pseudotuberculosis I19 as a case study. J Microbiol Methods, v. 86, p. 218-23, 2011.

50.CERDEIRA, V.L. T, et al. IncX3 plasmid harboring a non-Tn4401 genetic element (NTE (KPC)) in a hospital-associated clone of KPC-2-producing Klebsiella pneumoniae ST340/CG258. Diagn Microbiol Infect Dis., v. S0732-8893, p. 30213-4, 2017.

51.CERGOLE-NOVELLA, M. C, et al. First Description of bla $a_{\mathrm{CTX}-\mathrm{M}-14-}$ and bla $a_{\mathrm{CTX}-\mathrm{M}-15^{-}}$ Producing Escherichia coli Isolates in Brazil. Microbial Drug Resistance, v.16, p. 177-184, 2010.

52.CHATTAWAY, M.A., SCHAEFER, U., TEWOLDE, R., DALLMAN, T.J., JENKINS, C. Identification of Escherichia coli and Shigella Species from Whole-Genome Sequences. J. Clin. Microbiol., v. 55, p. 616-623, 2017.

53.CHENG, V.C., WONG, S.C., HO, P.L., YUEN, K.Y. Strategic measures for the control of surging antimicrobial resistance in Hong Kong and mainland of China. Emerg Microbes Infect., v. 4, p. e8,2015.

54.CISNEROS, J.M., COBO, J., SAN JUAN, R., MONTEJO, M., FARIÑAS, M.C. Education on antibiotic use. Education systems and activities that work. Enferm. Infecc. Microbiol. Clin., v. 31, p. 31-37.

55.CLERMONT, O., BONACORSI, S., BINGEN, E. Rapid and simple determination of the Escherichia coli phylogenetic group. Appl. Environ. Microbiol., v. 66, p. 4555-4558, 2000.

56.CLERMONT, O., GORDON, D., DENAMUR, E. Guide to the various phylogenetic classification schemes for Escherichia coli and the correspondence among schemes. Microbiology, v. 161, p. 980-988, 2015.

57.CLINICAL AND LABORATORY STANDARDS INSTITUTE. Performance standards for antimicrobial susceptibility testing; 28th informational supplement. CLSI document M100-S27. Clinical and Laboratory Standards Institute, Wayne, PA, 2018.

58.CONCEIÇÃO-NETO， O.C， AIRES， C.A.M., PEREIRA， N.F., DA SILVA, L.H.J., PICÃO, R.C., SIQUEIRA, B.N., ALBANO, R.M., ASENSI, M.D, CARVALHOASSEF, A.P.D. Detection of the plasmid-mediated $m c r-1$ gene in clinical KPC-2-producing Escherichia coli isolates in Brazil. Int J Antimicrob Agents. v.50, p. 282-284, 2017.

59.CONRAD, P.A, et al. Operationalizing a One Health approach to global health challenges. Comp Immunol Microbiol Infect Dis. v. 36, p. 211-6, 2013.

60.COUTURIER, M., BEX, F., BERGQUIST, P.L., MAAS, W.K. Identification and classification of bacterial plasmids. Microbiol Rev., v. 52, p. 375-95, 1988. 
61.COURTENAY, M., CASTRO-SÁNCHEZ, E., DESLANDES, R., HODSON, K., LIM, R., MORRIS, G., REEVES, S., WEISS, M. Defining antimicrobial stewardship competencies for undergraduate health professional education in the United Kingdom: A study protocol. $\boldsymbol{J}$. Interprof. Care., v. 32, p. 638-640, 2018.

62.COQUE, T.M. et al. Genes encoding TEM-4, SHV-2, and CTX-M-10 extended-spectrum beta- lactamases are carried by multiple Klebsiella pneumoniae clones in a single hospital (Madrid, 1989 to 2000). Antimicrob. Agents Chemother., v. 46, p. 500-510, 2002.

63.CROXEN, M.A; FINLAY, B.B. Molecular mechanisms of Escherichia coli pathogenicity. Nat. Rev., v. 8, p. 26-38, 2010.CROXEN, M.A., LAW, R.J., SCHOLZ, R., KEENEY, K.M., WLODARSKA, M., FINLAY, B.B. Recent advances in understanding enteric pathogenic Escherichia coli. Clin. Microbiol. Rev., v. 26, p. 822-80, 2013.

64.CUNHA, M.P., LINCOPAN, N., CERDEIRA, L., ESPOSITO, F., DROPA, M., FRANCO, L.S., MORENO, A.M., KNÖBL, T. Coexistence of CTX-M-2, CTX-M-55, CMY2, FosA3, and QnrB19 in Extraintestinal Pathogenic Escherichia coli from Poultry in Brazil. Antimicrob Agents Chemother. v. 61, pii: e02474-16, 2017.

65.CURY, J., OLIVEIRA, P.H., DE LA CRUZ, F., ROCHA,E.P.C. Host range and genetic plasticity explain the co-existence of integrative and extrachromosomal mobile genetic elements. Mol Biol Evol. 2018 Jun 14. 2018 Nov 1;35(11):2850.

66.D'ANDREA, M.M., ARENA, F., PALLECCHI, L., ROSSOLINI, G.M. CTX-M-type Blactamases: a successful story of antibiotic resistance. Intern. J. Med. Microbiol., v. 303, p. 305-307, 2013.

67.DALE, A.P., WOODFORD, N. Extra-intestinal pathogenic Escherichia coli (EXPEC): Disease, carriage and clones. Infect., v. 71, p. 615-626, 2015.

68.DALMOLIN, T.V, CASTRO, L., MAYER, F.Q., ZAVASCKI A.P., MARTINS, A.F., LIMA-MORALES, D., BARTH, A.L. Co-occurrence of $m c r-1$ and bla $a_{\mathrm{KPC}-2}$ in a clinical isolate of Escherichia coli in Brazil. J Antimicrob Chemother. v. 72, p.2404-2406, 2017.

69.DANTAS-PALMEIRA, J., FERREIRA, H., MADEC, J.Y., HAENNI, M. Pandemic Escherichia coli ST648 isolate harbouring fosA3 and bla(CTX-M-8) on an IncI1/ST113 plasmid: A new successful combination for the spread of fosfomycin resistance? J. Glob. Antimicrob.Resist., v.15, p.254-255, 2018.

70.DATTA. N., HUGHES, V.M. Plasmids of the same Inc groups in Enterobacteria before and after the medical use of antibiotics. Nature. v. 306, p. 616-7, 1983.

71.DATTA, N; HEDGES, R.W. Compatibility groups among fi-R factors. Nature, v.52, p. 222-223, 1971.

72.DE ARAUJO, C.F., SILVA, D.M., CARNEIRO, M.T., RIBEIRO, S., FONTANAMAURELL, M., ALVAREZ, P., ASENSI, M.D., ZAHNER, V., CARVALHO-ASSEF, A.P. Detection of Carbapenemase Genes in Aquatic Environments in Rio de Janeiro, Brazil. Antimicrob. Agents. Chemother., v.60, p.4380-3, 2016. 
73.DEL SOLAR,G., ALONSO, J.C., ESPINOSA, M., DÍAZ-OREJAS, R. Broad-host-range plasmid replication: an open question. Mol Microbiol., v. 21, p.661-666, 1996.

74.DEL SOLAR, G., GIRALDO R., RUIZ-ECHEVARRÍA M.J., ESPINOSA M., DÍAZOREJAS R.. Replication and control of circular bacterial plasmids. Microbiol. Mol. Biol Rev. v. 62, p. 434-64,1998.

75.DEL SOLAR, G., ESPINOSA, M. Plasmid copy number control: an evergrowing story. Mol. Microbiol. v. 37, p.492-500, 2000.

76.DENG Y., BAO X., JI L., CHEN L., LIU J., MIAO J., CHEN D., BIAN H., LI Y., YU G. Resistance integrons: class 1, 2 and 3 integrons. Ann Clin Microbiol Antimicrob. p.14-45, 2015 .

77.DIB, J.R., WAGENKNECHT, M., FARÍAS, M.E., MEINHARDT, F. Strategies and approaches in Plasmidome studies-uncovering plasmid diversity disregarding of linear elements? Front. Microbiol., v. 6, 2015.

78.DI PILATO, V., ARENA, F., GIANI, T., CONTE, V., CRESTI, S., ROSSOLINI, G.M.Characterization of a conjugative IncL/M plasmid encoding the FOX-7 AmpC-type $\beta$ lactamase, involved in a large outbreak in a neonatal intensive care unit. J. Antimicrob. Chemother., v. 69, p. 2620-2624, 2014.

79.DI PILATO, V, et al. $m c r-1.2$, a New mcr Variant Carried on a Transferable Plasmid from a Colistin-Resistant KPC Carbapenemase-Producing Klebsiella pneumoniae Strain of Sequence Type 512. Antimicrob Agents Chemother., v. 60, p. 5612-5, 2016.

80.DHANJI, H., MURPHY, N.M., DOUMITH, M., DURMUS, S., LEE, S.S., HOPE, R., WOODFORD, N., LIVERMORE, D.M. Cephalosporin resistance mechanisms in Escherichia coli isolated from raw chicken imported into the UK. J Antimicrob Chemother, v. 65, p. 2534- 2537, 2010.

81.DOI, Y., IOVLEVA, A., BONOMO, R.A. The ecology of extended-spectrum $\beta$ lactamases (ESBLs) in the developed world. J. Travel. Med., v. 24(suppl_1):S44-S51, 2017.

82.DOBIASOVA, H, DOLEJSKA, M. Prevalence and diversity of IncX plasmids carrying fluoroquinolone and $\beta$-lactam resistance genes in Escherichia coli originating from diverse sources and geographical areas. J Antimicrob Chemother. v. 71, p. 2118-24, 2016.

83.DRAENERT, R., SEYBOLD, U., GRÜTZNER, E., BOGNER, J.R. Novel antibiotics: are we still in the pre-post-antibiotic era? Infection, v. 43, p. 145-151, 2015.

84.DROPA, M. Caracterização genotípica de cepas da família Enterobacteriaceae produtoras de $\beta$-lactamases de espectro estendido, isoladas de pacientes de um hospital de rede pública da cidade de São Paulo. 2006. 116 f. Dissertação (Mestrado em Saúde Pública) -Faculdade de Saúde Publica - USP.

85.DROPA, M. Disseminação da resistência a antimicrobianos em cepas clínicas e ambientais de Enterobacteriaceae: identificação e mapeamento do ambiente genético dos genes 
codificadores de ESBL. 2012 .121f. Tese (Doutorado em Saúde Pública)- Faculdade de Saúde Publica - USP.

86.DROPA, M., GHIGLIONE, B., MATTÉ, M.H., BALSALOBRE, L.C., LINCOPAN, N., MATTÉ, G.R., GUTKIND, G., POWER, P. Molecular and Biochemical Characterization of CTX-M-131, a Natural Asp240Gly Variant Derived from CTX-M-2, Produced by a Providencia rettgeri Clinical Strain in São Paulo, Brazil. Antimicrob. Agents Chemother., v. 59, p. 1815-1817, 2015.

87.DROPA, M., LINCOPAN, N., BALSALOBRE, L.C., OLIVEIRA, D.E., MOURA, R.A., FERNANDES, M.R., SILVA, Q.M., MATTÉ, G.R., SATO, M.I., MATTÉ, M.H. Genetic background of novel sequence types of CTX-M-8- and CTX-M-15-producing Escherichia coli and Klebsiella pneumoniae from public wastewater treatment plants in São Paulo, Brazil. Environ. Sci. Pollut. Res. Int., v. 23, p.4953-4958, 2016.

88.DU, H, et al. Emergence of the $m c r-1$ colistin resistance gene in carbapenem-resistant Enterobacteriaceae. Lancet Infect Dis., 16: 287-8, 2016.

89.DURAND, G.A., RAOULT, D., DUBOURG, G. Antibiotic discovery: history, methods and perspectives. Int. J. Antimicrob. Agents, v. 53, p.371-382, 2019.

90.ELLEM, J.A, et al. Locally Acquired mcr-1 in Escherichia coli, Australia, 2011 and 2013. Emerg Infect Dis., v. 23, p. 1160-1163,2017.

91.ELLER, C, et al. Emergence of extended-spectrum $\beta$-lactamase (ESBL) CTX-M-8 in Germany. J Antimicrob Chemother. v. 69, p. 562-4, 2014.

92.EGERVÄRN, M., BÖRJESSON, S., BYFORS, S., FINN, M., KAIPE, C., ENGLUND, S., LINDBLAD, M. Escherichia coli with extended-spectrum beta-lactamases or transferable AmpC beta-lactamases and Salmonella on meat imported into Sweden. Int. J. Food Microbiol, v. 171, p. 8-14, 2014.

93.EUROPEAN COMMITTEE ON ANTIMICROBIAL SUSCEPTIBILITY TESTING. Breakpoints tables for interpretation of MICs and zone diameters, version 6.0., 2016.

94.ESCUDERO, J.A., LOOT, C., NIVINA, A, MAZEL D. The Integron: Adaptation On Demand. Microbiol. Spectr. v.3, MDNA3-0019-2014, 2015.

95.ESPINAL et al., FIRST DESCRIPTION OF $B L A_{\mathrm{NDM}-7}$ CARRIED ON AN INCX4 PLASMID IN Escherichia coli ST679 Isolated in Spain. Microb Drug Resist. 2017 [Epub ahead of print]

96.EVANS, B.R., LEIGHTON, F.A. A history of One Health. Rev Sci Tech., v.33, p.413-20, 2014.

97.FALAGAS, M.E; KASIAKOU, S.K. Colistin: the revival of polymyxins for the management of multidrug-resistant Gram-negative bacterial infections. Clin Infect Dis, v. 40, p.1333-1341, 2005.

98.FALAGAS, M.E., RAFAILIDIS, P.I., MATTHAIOU, D.K.. Resistance to polymyxins: 
mechanisms, frequency and treatment options. Drug Resist Updat, v. 13, p. 132-138, 2010.

99.FALGENHAUER, L, et al. Colistin resistance gene $m c r-1$ in extended-spectrum $\beta$ lactamase-producing and carbapenemase-producing Gram-negative bacteria in Germany. Lancet Infect Dis. v. 16, p. 282-3, 2016.

100.FANG, L., LI, X., LI, L., LI, S., LIAO, X., SUN, J., LIU, Y. Co-spread of metal and antibiotic resistance within ST3-IncHI2 plasmids from E. coli isolates of food-producing animals. Sci Rep. v. 6, p. 25312, 2016

101.FOOD AND AGRICULTURE ORGANIZATION OF THE UNITED NATIONS (FAO), WORLD ORGANISATION FOR ANIMAL HEALTH (OIE) AND WORLD HEALTH ORGANIZATION (WHO). The Tripartite's Commitment Providing multi-sectoral, collaborative leadership in addressing health challenges, 2017. (Acesso em: 10 de maio de 2019) https://www.who.int/zoonoses/tripartite_oct2017.pdf?ua=1.

102.FEIJAO, P., YAO, H.T., FORNIKA, D., GARDY, J., HSIAO, W., CHAUVE, C., CHINDELEVITCH, L. MentaLiST - A fast MLST caller for large MLST schemes. Microb Genom., 2018 (in press: doi: 10.1099/mgen.0.000146)

103.FERREIRA, J.C., PENHA FILHO, R.A., ANDRADE, L.N., BERCHIERI, A., J.R, DARINI, A.L. IncI1/ST113 and IncI1/ST114 conjugative plasmids carrying blaCTX-M-8 in Escherichia coli isolated from poultry in Brazil. Diagn Microbiol Infect Dis., v. 80, p. 304-6, 2014

104.FERREIRA, J.C, et al. Detection of chromosomal bla $a_{\mathrm{CTX}-\mathrm{M}-2}$ in diverse E. coli isolates from healthy broiler chickens. Clin. Microbiol. Infect., 2014.

105. FERNANDES, M. R, et al. Silent dissemination of colistin-resistant Escherichia coli in South America could contribute to the global spread of the $m c r-1$ gene. Euro Surveill. v.28, 2016a.

106.FERNANDES, M.R., MCCULLOCH, J.A., VIANELLO, M.A., MOURA, Q., PÉREZCHAPARRO, P.J., ESPOSITO, F., SARTORI, L., DROPA, M., MATTÉ, M.H., LIRA, D.P., MAMIZUKA, E.M., LINCOPAN, N. Report of the Globally Disseminated IncX4 Plasmid Carrying the $m c r-1$ Gene in a Colistin-Resistant Escherichia coli Sequence Type 101 Isolate from a Human Infection in Brazil. Antimicrob Agents Chemother. v. 23, p. 6415-641, 2016 b.

107.FERNANDES, M.R., SELLERA, F.P., ESPOSITO, F., SABINO, C.P., CERDEIRA, L., LINCOPAN, N. Colistin-resistant mcr-1-positive Escherichia coli in public beaches, an infectious threat emerging in recreational waters. Antimicrob. Agents Chemother. v.61: e00234-17, 2017.

108.FERNANDES, M.R., SELLERA, F.P., MOURA, Q., CARVALHO, M.P.N., ROSATO, P.N., CERDEIRA, L., LINCOPAN, N. Zooanthroponotic Transmission of Drug-Resistant Pseudomonas aeruginosa, Brazil. Emerg. Infect. Dis., v.24, p.1160-1162, 2018a

109.FERNANDES, M.R., SELLERA, F.P., MOURA, Q., GASPAR, V.C., CERDEIRA, L., LINCOPAN N. International high-risk clonal lineages of CTX-M-producing Escherichia coli F-ST648 in free-roaming cats, South America. Infect. Genet. Evol., v.66, p. 48-51, 2018b. 
110.FERNANDES, M.R., SELlERA, F.P., MOURA, Q., SOUZA, T.A., LINCOPAN, N. Draft genome sequence of a CTX-M-8, CTX-M-55 and FosA3 co-producing Escherichia coli ST117/B2 isolated from an asymptomatic carrier. J. Glob. Antimicrob. Resist. , v.12, p.183184, 2018c.

111.FERNANDES MR, CERDEIRA L, SILVA MM, SELLERA FP, MUÑOZ M, JUNIOR FG, AZEVEDOSS, POWER P, GUTKIND G, LINCOPAN N. Novel $m c r-5.3$ variant in a CTX-M-8-producing Escherichia coli ST711 isolated from an infected horse. J Antimicrob Chemother., v.73, p.3520-3522, $2018 \mathrm{~d}$.

112.FERNÁNDEZ-GARCÍA, L., BLASCO, L., LOPEZ, M., BOU, G., GARCÍACONTRERAS, R., WOOD, T., TOMAS, M. Toxin-Antitoxin Systems in Clinical Pathogens. Toxins, v. 20, pii: E227, 2016.

113.FONDI, M; FANI, R. The horizontal flow of the plasmid resistome: clues from intergeneric similarity networks. Environ. Microbiol., v. 12, p. 3228-3242, 2010.

114.FROST, L.S., LEPLAE, R., SUMMERS, A.O., TOUSSAINT, A. MOBILE GENETIC elements: the agents of open source evolution. Nat. Ver. Microbiol. v. 9, p.722-32, 2005.

115.FUENTES-CASTILLO, D., FARFÁN-LÓPEZ, M., ESPOSITO, F., MOURA, Q., FERNANDES, M. R., LOPES, R., CARDOSO, B., MUÑOZ, M.E., CERDEIRA, L., NAJLE, I., MUÑOZ, P.M., CATÃO-DIAS, J.L., GONZÁLEZ-ACUÑA, D., LINCOPAN. Wild owls colonized by international clones of extended-spectrum $\beta$-lactamase (CTX-M) -producing Escherichia coli and Salmonella Infantis in the Southern Cone of America. Science of the Total Environ., 2019. (in press)

116.FURUYA, E.Y., LOWY, F.D. Antimicrobial-resistant bacteria in the community setting. Nat. Rev. Microbiol. v. 4, p.36-45, 2006.

117.GARCÍA-FERNÁNDEZ, A, et al. Rapid pulsed-field gel eletrophoresis protocol for typing of Escherichia coli $\mathrm{O} 157: \mathrm{H} 7$ and other gram-negative organisms in 1 day. J. Clin. Microbiol., v. 34, p. 2448-2453, 1997.

118.GARCÍA-FERNÁNDEZ, A., CHIARETTO, G., BERTINI, A., VILLA, L., FORTINI, D., RICCI, A., CARATTOLI, A. Multilocus Sequence Typing of IncI1 plasmids carrying extended- spectrum $\beta$-lactamases in Escherichia coli and Salmonella of human and animal origin. J. Antimicrob. Chemoth., v. 61, p. 1229-1233, 2008.

119.GARCÍA-FERNÁNDEZ, A., VILLA, L., MOODLEY, A., HASMAN, H., MIRIAGOU, V., GUARDABASSI, L., CARATTOLI, A. A Multilocus sequence typing of IncN plasmids. J Antimicrob Chemother., v. 66, p. 1987-91, 2011.

120.GILLINGS, M.R. Integrons: past, present, and future. Microbiol Mol Biol Rev. v.78, p. 257-77, 2014

121.GILLINGS, M.R. Evolutionary consequences of antibiotic use for the resistome, mobilome and microbial pangenome. Front. Microbiol., v. 4, 2013. 
122. GILRANE, V.L., LOBO, S., HUANG, W., ZHUGE, J., YIN, C., CHEN, D., ALVAREZ, K.J., BUDHAI, A., NADELMAN, I., DIMITROVA, N., FALLON, J.T., WANG, G. Complete Genome Sequence of a Colistin-Resistant Escherichia coli Strain Harboring mcr-1 on an IncHI2 Plasmid in the United States. Genome Announc. 5(42), 2017.

123.GHOSH, H., DOIJAD, S., FALGENHAUER, L., FRITZENWANKER, M., IMIRZALIOGLU, C., CHAKRABORTY, T. bla(CTX-M-27)-Encoding Escherichia coli Sequence Type 131 Lineage C1-M27 Clone in Clinical Isolates, Germany. Emerg Infect Dis., v.23, p. 1754-1756, 2017.

124.GLOBAL ANTIMICROBIAL RESISTANCE SURVEILLANCE SYSTEM (GLASS) report: early implementation 2017-2018. Geneva: World Health Organization. Licence: CC BY-NC-SA 3.0 IGO, 2018.

125.GOLDBERG, D.W., FERNANDES, M.R., SELLERA, F.P., COSTA, D.G.C., LOUREIRO BRACARENSE, A.P., LINCOPAN, N. Genetic background of CTX-M-15producing Enterobacter hormaechei ST114 and Citrobacter freundii ST265 co-infecting a free-living green turtle (Chelonia mydas). Zoonoses Public Health, 2019 (in press).

126.GOMES, T.A., ELIAS, W.P., SCALETSKY, I.C., GUTH, B.E., RODRIGUES, J.F., PIAZZA, R.M., FERREIRA, L.C., MARTINEZ, M.B. Diarrheagenic Escherichia coli. Braz. J. Microbiol., v.47, p.3-30, 2016.

127.GONULLU, N., AKTAS, Z., KAYACAN, C.B., SALCIOGLU, M., CARATTOLI, A., YONG, D.E., WALSH, T.R.. Dissemination of CTX-M-15 beta-lactamase genes carried on Inc FI and FII plasmids among clinical isolates of Escherichia coli in a university hospital in Istanbul, Turkey. J Clinical Microbiol., v. 46, p. 1110-1112, 2008.

128.GONZÁLEZ-ZORN, B., ESCUDERO, J.A. Ecology of antimicrobial resistance: humans, animals, food and environment. Int. Microbiol., v.15, p.101-109, 2012.

129.GOTTESMAN, T., AGMON, O., SHWARTZ, O., DAN, M. Household transmission of carbapenemase-producing Klebsiella pneumoniae. Emerg. Infect. Dis., v.14, p.859-60, 2008.

130.GUZMÁN-BLANCO, M., LABARCA, J.A., VILlEGAS, M.V., GOTUZZO, E. Extended spectrum $\beta$-lactamase producers among nosocomial Enterobacteriaceae in Latin America. Braz. J. Infect. Dis., v. 18, p. 421-433, 2014.

131.GRAMI, R., MANSOUR, W., MEHRI, W., BOUALLÈGUE, O., BOUJAÂFAR, N., MADEC, J.Y., HAENNI, M. Impact of food animal trade on the spread of $m c r$ - 1 -mediated colistin resistance, Tunisia. Euro Surveill., v.21, 2016.

132.GRUBER, T.M., et al. Hamprecht A. Pathogenicity of pan-drug-resistant Serratia marcescens harbouring bla NDM-1. J. Antimicrob. Chemoth., v. 7, p. 1026-1030, 2015.

133.HADJADJ, L., RIZIKI, T., ZHU, Y., LI, J., DIENE, S.M., ROLAIN, J.M. Study of $m c r-1$ Gene-Mediated Colistin Resistance in Enterobacteriaceae Isolated from Humans and Animals in Different Countries. Genes (Basel)., v. 8, 2017. 
134.HAENNI $\mathrm{M}$, et al. Co-occurrence of extended spectrum $\beta$ lactamase and MCR-1 encoding on plasmids. Lancet Infect Dis. v. 16, p. 281-2, 2016.

135.HALL, A. R. Integrons and gene cassettes: hotspots of diversity in bacterial genomes. Ann. N Y. Acad. Sci., v.1267, p. 71-78, 2012.

136.HALL, A.R., et al. Costs of antibiotic resistance - separating trait effects and selective effects. Evol Appl. v.8, p. 261-72,2015.

137.HAMMERL, J.A., BOROWIAK, M., SCHMOGER, S., SHAMOUN, D., GROBBEL, M., MALORNY, B., TENHAGEN, B.A., KÄSBOHRER, A. $m c r-5$ and a novel $m c r-5.2$ variant in Escherichia coli isolates from food and food-producing animals, Germany, 2010 to 2017. J Antimicrob Chemother., v.73, p.1433-1435, 2018.

138.HANAHAN, D. Studies on transformation of Escherichia coli with plasmids. $\boldsymbol{J}$ Mol. Biol., v. 166, p. 557-580, 1983.

139.HARMER, C.J., HALL, R.M. The A to Z of A/C plasmids. Plasmid, v.80, p. 63-82, 2015.

140.HARRIS, P.N, TAMBYAH, P.A., PATERSON, D.L. $\beta$-lactam and $\beta$-lactamase inhibitor combinations in the treatment of extended-spectrum $\beta$-lactamase producing Enterobacteriaceae: time for a reappraisal in the era of few antibiotic options? Lancet. Infect. Dis., v. 15, p. 475-485, 2015.

141.HASMAN, H, et al. Detection of $m c r-1$ encoding plasmid- mediated colistin-resistant Escherichia coli isolates from human bloodstream infection and imported chicken meat, Denmark. Euro Surveill. v. 20, 2015.

142.HINCHLIFFE, S. More than one world, more than one health: re-configuring interspecies health. Soc. Sci. Med., v.129, p. 28-35, 2015.

143.HU, Y. Dissemination of the mcr-1 colistin resistance gene. Lancet Infect Dis., v. 16, p. 146-147, 2016.

144.HUBÁLEK, Z. Emerging human infectious diseases: anthroponoses, zoonoses, and sapronoses. Emerg. Infect. Dis., v.9, p.403-404, 2003.

145.INSTITUTO BRASILEIRO DE GEOGRAFIA E ESTATÍSTICA (IBGE). DOU n ${ }^{\circ} 53$ de 19/03/2019, conforme Resolução No 01, de 18 de março de 2019. (Acesso em: 1 de abril de 2019). https://www.ibge.gov.br/geociencias/organizacao-do-territorio/estruturaterritorial/15761-areas-dos-municipios.html?=\&t=o-que-e

146 IZDEBSK et al,. Clonal structure, extended-spectrum $\beta$-lactamases, and acquired AmpCtype cephalosporinases of Escherichia coli populations colonizing patients in rehabilitation centers in four countries. Antimicrob. Agents Chemother., p. 57, p. 309-316, 2013.

147.JACKSON, N., CZAPLEWSKI, L., PIDDOCK, L.J.V. Discovery and development of new antibacterial drugs: learning from experience? J. Antimicrob. Chemother. v. 73, p.14521459. 
148.JOHNSON， T.J., BIELAK， E.M., FORTINI， D., HANSEN， L.H., HASMAN, H., DEBROY, C., NOLAN, L.K., CARATTOLI, A. Expansion of the IncX plasmid family for improved identification and typing of novel plasmids in drug-resistant Enterobacteriaceae. Plasmid. v. 68, p. 43-50, 2012.

149.JOHNSON, I., HANSEN, A, BI, P. The challenges of implementing an integrated One Health surveillance system in Australia. Zoonoses Public Health, v. 65, p. e229-e236, 2018.

150.JOHNSON, J.R., RUSSO, T.A. Molecular Epidemiology of Extraintestinal Pathogenic Escherichia coli. EcoSal Plus, v. 8, 2018.

151.JONES, C., STANLEY, J. Salmonella plasmids of the pre-antibiotic era. J Gen Microbiol. v. 138, p. 189-97, 1992.

152.JOUINI, A., et al. Lineages and virulence gene content among extended-spectrum $\beta$ actamase-producing Escherichia coli strains of food origin in Tunisia. J Food Prot. v. 76, p. 323-7, 2013.

153.JUBELIN, G., DESVAUX, M., SCHÜLLER, S., ETIENNE-MESMIN, L., MUNIESA, M., BLANQUET-DIOT, S. Modulation of Enterohaemorrhagic Escherichia coli Survival and Virulence in the Human Gastrointestinal Tract. Microorganisms. v.6, p. pii: E115, 2018.

154.KAPER, J.B., NATARO, J.P., MOBLEY, H.L. Pathogenic Escherichia coli. Nat. Rev. Microbiol., v. 2, p.123-140, 2004.

155.KAUSHIK, M., KUMAR, S., KAPOOR, R.K., VIRDI, J.S., GULATI, P. Integrons in Enterobacteriaceae: diversity, distribution and epidemiology. Int J Antimicrob Agents. v.51, p.167-176, 2018.

156.KAWAMURA K, et al. Molecular epidemiology of extended-spectrum $\beta$-lactamases and Escherichia coli isolated from retail foods including chicken meat in Japan. Foodborne Pathog. Dis. v. 11, p. 104-10, 2014.

157.KAWAMURA, K., HAYASHI, K., MATSUO, N., KITAOKA, K., KIMURA, K., WACHINO, J.I., KONDO, T., IINUMA, Y., MURAKAMI, N., FUJIMOTO, S., ARAKAWA, Y. Prevalence of CTX-M-Type Extended-Spectrum $\beta$-Lactamase-Producing Escherichia coli B2-O25-ST131 H30R Among Residents in Nonacute Care Facilities in Japan. Microb. Drug Resist. 2018 (doi: 10.1089/mdr.2018.0068).

158.KHAN, S.A. Plasmid rolling-circle replication: highlights of two decades of research. Plasmid, v. 53, p.126-136, 2005.

159.KIEFFER, N., AIRES-DE-SOUSA, M., NORDMANN, P., POIREL, L. High Rate of MCR-1-Producing Escherichia coli and Klebsiella pneumoniae among Pigs, Portugal. Emerg Infect Dis., v. 23, p.2023-2029, 2017.

160.KIIRU, J., et al. Analysis of $\beta$-lactamase phenotypes and carriage of selected $\beta$-lactamase genes among Escherichia coli strains obtained from Kenyan patients during an 18-year period. BMC Microbiol. v. 28, p.155,2012. 
161.KLEIN, E.Y., VAN BOECKEL, T.P., MARTINEZ, E.M., PANT, S., GANDRA, S., LEVIN, S.A., GOOSSENS, H., LAXMINARAYAN, R. Global increase and geographic convergence in antibiotic consumption between 2000 and 2015. Proc. Natl. Acad. Sci. U.S.A, v.115:E3463-E3470, 2018.

162.KIRCHNER, M, et al Cefotaxime resistant Escherichia coli collected from a healthy volunteer; characterisation and the effect of plasmid loss. PLoS One., v. 27, p. e84142, 2013.

163.KOGA， V.L., RODRIGUES， G.R., SCANDORIEIRO, S., VESPERO, E.C., OBA, A., DE BRITO, B.G., DE BRITO, K.C., NAKAZATO, G., KOBAYASHI, R.K. Evaluation of the Antibiotic Resistance and Virulence of Escherichia coli Strains Isolated from Chicken Carcasses in 2007 and 2013 from Paraná, Brazil. Foodborne Pathog. Dis., v. 12, p. 479-85, 2015.

164.KOSTYLA, C., BAIN, R., CRONK, R., BARTRAM, J. Seasonal variation of fecal contamination in drinking water sources in developing countries: a systematic review. Sci. Total Environ., v. 514, p. 333-343, 2015.

165.KUO, S.C, et al. Colistin resistance gene $m c r-1$ in Escherichia coli isolates from humans and retail meats, Taiwan. J Antimicrob Chemother., 71: 2327-9, 2016.

166.LAHLAOUI, H., BEM, H.A.J., KHALIFA, A., BEM MOUSSA, M. Epidemiology of Enterobacteriaceae producing CTX-M type extended spectrum $\beta$-lactamase (ESBL). Med. Mal. Infect., v. 44, p. 400-404, 2014.

167.LARTIGUE M.F, POIREL L., AUBERT D., NORDMANN P. In vitro analysis of ISEcp1B-mediated mobilization of naturally occurring beta-lactamase gene blaCTX-M of Kluyvera ascorbata. Antimicrob Agents Chemother., v. 50, p. 1282-1286, 2006.

168.LEE, C.R., LEE, J.H., KANG, L.W., JEONG, B.C., LEE, S.H. Educational effectiveness, target, and content for prudent antibiotic use. Biomed. Res. Int., 214021, 2015.

169.LEIGUE, L., WARTH, J.F., MELO, L.C., SILVA, K.C., MOURA, R.A., BARBATO, L; SILVA, L.C., SANTOS, A.C., SILVA, R.M., LINCOPAN, N. MDR ST2179-CTX-M-15 Escherichia coli co-producing RmtD and AAC (6') -Ib-cr in a horse with extraintestinal infection, Brazil. J Antimicrob Chemother. v. 70, p. 1263-5, 2015.

170.LEISTNER, R., SAKELLARIOU, C., GÜRNTKE, S., KOLA, A., STEINMETZ, I., KOHLER, C., PFEIFER, Y., ELLER, C., GASTMEIER, P., SCHWAB, F. Mortality and molecular epidemiology associated with extended-spectrum $\beta$-lactamase production in Escherichia coli from bloodstream infection. Infect. Drug Resist., v. 7:57-62, 2014.

171.LENTZ, S. A, et al. Letter to the editor: Escherichia coli harbouring $m c r-1$ gene isolated from poultry not exposed to polymyxins in Brazil. Euro Surveill., v. 30;21, 2016.

172.LERNER, H., BERG, C. The concept of health in One Health and some practical implications for research and education: what is One Health? Infect. Ecol. Epidemiol., v.5, p.25300, 2015. 
173.LEUKO, S; RAIVIO, T. L. Mutations that impact the enteropathogenic Escherichia coli Cpx envelope stress response attenuate virulence in Galleria mellonella. Infect Immun. v. 80, p. $3077-85,2012$.

174.LI, R., XIE, M., ZHANG, J., YANG, Z., LIU, L., LIU, X., ZHENG, Z., CHAN, E.W., CHEN, S. Genetic characterization of mcr-1-bearing plasmids to depict molecular mechanisms underlying dissemination of the colistin resistance determinant. J Antimicrob Chemother,v.72,p.393-401, 2017

175.LIU, X., et al. Curing of Plasmid pXO1 from Bacillus anthracis Using Plasmid Incompatibility. PLoS ONE, v. 7, p. e29875, 2012.

176.LIU Y.Y., WANG Y., WALSH T.R., YI LX,. ZHANG R., SPENCER J., DOI Y., TIAN G., DONG B, .HUANG X., YU L.F., GU D., REN H., CHEN X., LV L., HE D., ZHOU H., LIANG Z., LIU J.H., SHEN J. Emergence of plasmid-mediated colistin resistance mechanism MCR-1 in animals and human beings in China: a microbiological and molecular biological study. Lancet Infect Dis. v. 16, p. 161-8, 2015.

177.MADEC, J.Y., HAENNI, M., NORDMANN, P., POIREL, L. Extended-spectrum $\beta$ lactamase/AmpC- and carbapenemase-producing Enterobacteriaceae in animals: a threat for humans? Clin Microbiol Infect. v. 23, p. 826-833, 2017

178.MACIEL, W.G., DA SILVA, K.E., CRODA, J., CAYÔ, R., RAMOS, A.C., DE SALES, R.O., DE ALMEIDA DE SOUZA, G.H., BAMPI, J.V.B., LIMIERE, L.C., CASAGRANDE, J.C., GALES, A.C., SIMIONATTO, S. Clonal spread of carbapenem-resistant Acinetobacter baumannii in a neonatal intensive care unit. J. Hosp. Infect., v.98, p.300-304, 2018.

179.MAIDEN, M.C., JANSEN VAN RENSBURG, M.J., BRAY, J.E., EARLE, S.G., FORD, S.A., JOLLEY, K.A., MCCARTHY, N.D. MLST revisited: the gene-by-gene approach to bacterial genomics. Nat. Rev. Microbiol., v.11, p.728-736, 2013.

180.MAKVANA, S., KRILOV, L.R. Escherichia coli Infections. Pediatr. Rev., v. 36, 2015.

181.MARSHALL, B.M; LEVY, S.B. Food animals and antimicrobials: impacts on human health. Clin. Microbiol. Rev., v. 24, p. 718-733.

182.MARTENS, E., DEMAIN, A.L. The antibiotic resistance crisis, with a focus on the United States. J. Antibiot. Tokyo, v.70, p. 520-526, 2017.

183.MATAMOROS, S., VAN HATTEM, J.M., ARCILLA, M.S., WILLEMSE, N., MELLES, D.C., PENDERS, J., VINHTN, THI HOA N; COMBAT CONSORTIUM, DE JONG MD, SCHULTSZ C. Global phylogenetic analysis of Escherichia coli and plasmids carrying the $m c r-1$ gene indicates bacterial diversity but plasmid restriction. Sci Rep. V. 10 p.15364, 2017.

184.MATHERS, A.J., PEIRANO, G., PITOUT, J.D. The Role of Epidemic Resistance Plasmids and International High-Risk Clones in the Spread of Multidrug-Resistant Enterobacteriaceae. Clin. Microbiol. Rev., v. 28, p. 565-591, 2015.

185.MARTINS, WMBS, NARCISO AC, CAYÔ R, SANTOS SV, FEHLBERG LCC, 
RAMOS PL, DA CRUZ JB, GALES AC. SPM-1-producing Pseudomonas aeruginosa ST277 clone recovered from microbiota of migratory birds. Diagn Microbiol Infect Dis., v. 9, p. 221227, 2018.

186.MCGANN, P, et al. Escherichia coli Harboring $m c r-1$ and bla $a_{\mathrm{CTX}-\mathrm{M}}$ on a Novel IncF Plasmid: First Report of $m c r-1$ in the United States. Antimicrob Agents Chemother.v. 60, p. 4420-1, 2016.

187.MELO, L.C., ORESCO, C., LEIGUE, L., NETTO, H.M., MELVILLE, P.A., BENITES, N.R., SARAS, E., HAENNI, M., LINCOPAN, N., MADEC, J.Y. Prevalence and molecular features of ESBL/pAmpC-producing Enterobacteriaceae in healthy and diseased companion animals in Brazil. Vet. Microbiol., v. 22, p.59-66, 2018.

188.MESSENGER, A.M., BARNES, A.N., GRAY, G.C. Reverse zoonotic disease transmission (zooanthroponosis): a systematic review of seldom-documented human biological threats to animals. PLoS One, v.9, p. e89055, 2014.

189.MINISTÉRIO DA SAÚDE. Secretaria de Vigilância em Saúde. Departamento de Vigilância das Doenças Transmissíveis. Plano de ação nacional de prevenção e controle da resistência aos antimicrobianos no âmbito da saúde única 2018-2022 (PAN-BR). Brasília: Ministério da Saúde, 2018.

190.MINISTÉRIO DA AGRICULTURA, PECUÁRIA E ABASTECIMENTO: MAPA. Uso de substância antimicrobiana em rações animais é proibido, 2016 (acesso em: 25 de março de 2019). (http://www.agricultura.gov.br/noticias/uso-de-substancia-antimicrobiana-em-racoesanimais-e-proibido).

191.MOHR, K.I. History of Antibiotics Research. Curr. Top. Microbiol. Immunol., v. 398, p. 237-272, 2016.

192.MONTE, D.F., MEM, A., FERNANDES, M.R., CERDEIRA, L., ESPOSITO, F., GALVÃO, J.A., FRANCO, B.D.G.M., LINCOPAN, N., LANDGRAF, M.Chicken Meat as a Reservoir of Colistin- Resistant Escherichia coli Strains Carrying mcr-1 Genes in South America. Antimicrob Agents Chemother., v. 61, p. e02718-16, 2017.

193.MONTE, D.F., SELLERA, F.P., FERNANDES, M.R., MOURA, Q., LANDGRAF, M., LINCOPAN, N. Genome Sequencing of an Escherichia coli Sequence Type 617 Strain Isolated from Beach Ghost Shrimp (Callichirus major) from a Heavily Polluted Ecosystem Reveals a Wider Resistome against Heavy Metals and Antibiotics. Microbiol. Resour. Announc., v.8. pii: e01471-18, 2019.

194.MOURA A., SOARES M., PEREIRA C., LEITÃO N., HENRIQUES I., CORREIA A. INTEGRALL: a database and search engine for integrons, integrases and gene cassettes. Bioinformatics, v. 25, p. 1096-1098, 2009.

195.MOURA, Q., ESPOSITO, F., FERNANDES, M.R., ESPINOZA-MUÑOZ, M., SOUZA, T.A., SANTOS, S.R., CERDEIRA, L., CASSETTARI, V., LINCOPAN, N. Genome sequence analysis of a hypermucoviscous/hypervirulent and MDR CTX-M-15/K19/ST29 Klebsiella pneumoniae isolated from human infection. Pathog. Dis., v. 29, 2017 a. 
196.MOURA, Q, et al. Virulent nontyphoidal Salmonella producing CTX-M and CMY-2 $\beta$ lactamases from livestock, food and human infection, Brazil. Virulence, v. 19, p. 1-6, 2017b.

197.MOURA, Q, et al. Draft genome sequence of a multidrug-resistant KPC-2-producing Enterobacter aerogenes isolated from a hospitalised patient in Brazil. J Glob Antimicrob Resist., v, 29, p. 277-278, 2017c.

198.MSHANA， S.E., IMIRZALIOGLU, C., HOSSAIN, H., HAIN, T., DOMANN, E., CHAKRABORTY, T. Conjugative IncFI plasmids carrying CTX-M-15 among Escherichia coli ESBL producing isolates at a University hospital in Germany. BMC Infect Dis, v. 9, p. 97, 2009.

199.MULVEY, M.R, et al. Dissemination of the $m c r-1$ colistin resistance gene. Lancet Infect Dis. v. 16, p. 289-90, 2016.

200.MUZAHEED, D.Y. et al. High prevalence of CTX-M-15-producing Klebsiella pneumoniae among inpatients and outpatients with urinary tract infection in Southern India. $J$. Antimicrob. Chemother., v.61, p. 1393-1394, 2008.

201.MWANGI, W., DE FIGUEIREDO, P., CRISCITIELLO, M.F. One Health: Addressing Global Challenges at the Nexus of Human, Animal, and Environmental Health. PLoS Pathog., v.12, p. e1005731, 2016.

202.NARCISO, A.C., MARTINS, W.M.B.S., CAYÔ, R., PEREIRA DE MATOS, A., SANTOS, S.V., RAMOS, P.L., BATISTA DA CRUZ, J., GALES, A.C. Detection of OXA58-Producing Acinetobacter seifertii Recovered from a Black-Necked Swan at a Zoo Lake. Antimicrob. Agents. Chemother., v.61, pii: e01360-17, 2017.

203.NASCIMENTO, T., CANTAMESSA, R., MELO, L., FERNANDES, M.R., FRAGA, E., DROPA, M., SATO, M.I.Z., CERDEIRA, L., LINCOPAN, N. International high-risk clones of Klebsiella pneumoniae KPC-2/CC258 and Escherichia coli CTX-M- 15/CC10 in urban lake waters. Sci. Total Environ., v. 15, p. 910-915, 2017.

204.NESME, J; SIMONET, P. The soil resistome: a critical review on antibiotic resistance origins, ecology and dissemination potential in telluric bacteria. Environ. Microbiol., v. 17, p. 913-930, 2015.

205.NI, B., et al. Curing of four different plasmids in Yersinia pestis using plasmid incompatibility. Lett. Appl. Microbiol., v. 47, p. 235-240, 2008.

206.NICOLAS, E., LAMBIN, M., DANDOY, D., GALLOY, C., NGUYEN, N., OGER, C.A., HALLET, B. The Tn3-family of Replicative Transposons. Microbiol Spectr. v. 3, 2015.

207.NICOLAS-CHANOINE, M.H., BERTRAND, X., MADEC, J.Y. Escherichia coli ST131, an intriguing clonal group. Clin. Microbiol. Rev., v. 27, p.543-74, 2014.

208.NOGUEIRA, K.S., CONTE, D., MAIA, F.V., DALLA-COSTA, L.M. Distribution of extended-spectrum $\beta$-lactamase types in a Brazilian tertiary hospital. Rev. Soc. Bras. Med. 
Trop., v. 48, p. 162-169, 2015.

209.NORDMANN, P., NAAS, T., POIREL, L. Global spread of Carbapenemase-producing Enterobacteriaceae. Emerg Infect Dis., v. 1, p. 1791-8, 2011.

210.NORIZUKI, C, et al. Specific bla (CTX-M-8) /IncI1 Plasmid Transfer among Genetically Diverse Escherichia coli Isolates between Humans and Chickens. Antimicrob Agents Chemother., v. 24, 2017.

211.NOVAIS, Â., VUOTTO, C., PIRES, J., MONTENEGRO, C., DONELLI, G., COQUE, T.M., PEIXE, L. Diversity and biofilm-production ability among isolates of Escherichia coli phylogroup D belonging to ST69, ST393 and ST405 clonal groups. BMC Microbiol., v.21, 13:144, 2013.

212.NOVAIS, A., CANTÓN, R., VALVERDE, A., MACHADO, E., GALÁN, J.C., PEIXE, L., CARATTOLI, A., BAQUERO, F., COQUE, T.M. Dissemination and persistence of

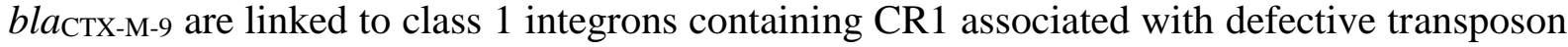
derivatives from Tn402 located in early antibiotic resistance plasmids of IncHI2, IncP1-alpha, and IncFI groups. Antimicrob Agents Chemother., v. 50, p. 2741-2750, 2006.

213.OLAITAN, A.O., MORAND, S., ROLAIN, J.M.. Mechanisms of polymyxin resistance: acquired and intrinsic resistance in bacteria. Front Microbiol, v. 5, p. 643, 2014.

214.OLAITAN, A. O, et al. Dissemination of the $m c r-1$ colistin resistance gene. Lancet Infect Dis., v. 16, p. 147, 2016.

215.OLIVEIRA FA, ZACCARIOTTO TR, PIVETA C, HOFLING CC, RESENDE MR, LEVY CE, ESPOSITO F, FERNANDES MR, CERDEIRA L, LINCOPAN N. MCR-1positive colistin-resistant Escherichia coli in immunocompromised hospitalised patients. Int. J. Antimicrob. Agents, v. 52, p. 438-440, 2018.

216.O'NEILL, J. The Review on Antimicrobial Resistance. Antimicrobial Resistance: Tackling a crisis for the health and wealth of nations. 2014.

(http://www.jpiamr.eu/wp- content/uploads/2014/12/AMR-Review-Paper-Tackling-a-crisisfor-the-health-and-wealth-of- nations_1-2.pdf.)

217.PAIVA, A.L., LINCOPAN, N., SILVA, K.C., NEVES, P.R., MORENO, A.M., MCCULLOCH, J.A., ASTOLFI-FERREIRA, C.S., FERREIRA, A.J. Low-virulence phylogenetic background of CTX-M-producing Escherichia coli isolated from extraintestinal infections. J. Infect. Dev. Ctries., v. 7, p. 756-760, 2013.

218.PAITAN, Y. Current Trends in Antimicrobial Resistance of Escherichia coli. Curr. Top. Microbiol. Immunol., v. 416, p. 181-211, 2018.

219.PARTRIDGE, S.R., TSAFNAT G., COIERA E., IREDELL J.R. Gene cassettes and cassette arrays inmobile resistance integrons. FEMS Microbiol. Rev., v. 33, p. 757-784, 2009.

220.PARTRIDGE S.R. Analysis of antibiotic resistance regions in Gram-negative bacteria. FEMS Microbiol Rev., v. 35, p. 820-55, 2011. 
221.PARTRIDGE S.R., KWONG S.M., FIRTH N., JENSEN S.O. Mobile Genetic Elements Associated with Antimicrobial Resistance. Clin Microbiol Rev., v. 31, pii.e00088-17, 2018.

222.PETCHIAPPAN, A., CHATTERJI D. Antibiotic Resistance: Current Perspectives. ACS Omega. v. 2, p. 7400-7409, 2017.

223.PERRETEN, V, et al. Colistin Resistance Gene $m c r-1$ in Avian- Pathogenic Escherichia coli in South Africa. Antimicrob Agents Chemother., v. 20, p. 4414-5, 2016.

224.PERRY, J. A; WRIGHT, G.D. Forces shaping the antibiotic resistome. Bioessays, v.36, p. 1179-1184, 2014.

225.PIDDOCK, L.J.V. Reflecting on the final report of the O'Neill Review on Antimicrobial Resistance. Lancet Infect. Dis. v. 16, p. 767-768, 2016.

226.POIREL, L, et al. Genetic Features of MCR-1-Producing Colistin- Resistant Escherichia coli Isolates in South Africa. Antimicrob Agents Chemother. v. 60, p. 4394-7, 2016.

227.POIREL, L., JAYOL, A., NORDMANN, P. Polymyxins: Antibacterial Activity, Susceptibility Testing, and Resistance Mechanisms Encoded by Plasmids or Chromosomes. Clin Microbiol Rev., v. 30, p. 557-596, 2017.

228.POIREL, L., MADEC, J.Y., LUPO, A., SCHINK, A.K., KIEFFER, N., NORDMANN, P., SCHWARZ, S. Antimicrobial Resistance in Escherichia coli. Microbiol Spectr. v., 2018.

229.QUEIROZ， M.L， ANTUNES， P., MOURÃO， J., MERQUIOR， V.L., MACHADO, E., PEIXE, L.V. Characterization of extended-spectrum beta-lactamases, antimicrobial resistance genes, and plasmid content in Escherichia coli isolates from different sources in Rio de Janeiro, Brazil. Diagn. Microbiol. Infect. Dis., v. 74, p. 91-64, 2012.

230.QUERESHI, Z.A; DOI, Y. Escherichia coli sequence type 131: epidemiology and challenges in treatment. Expert Ver. Anti Infect. Ther., v. 12, p. 597-609, 2014.

231.QUESADA, A, et al. Detection of plasmid mediated colistin resistance (MCR-1) in Escherichia coli and Salmonella enterica isolated from poultry and swine in Spain. Res Vet Sci. V. 105, p. 134-5, 2016.

232.QIAO, M., YING, G.G., SINGER, A.C., ZHU, Y.G. Review of antibiotic resistance in China and its environment. Environ. Int., v.110, p.160-172.

233.RAMSAY J.P., FIRTH N. Diverse mobilization strategies facilitate transfer of nonconjugative mobile genetic elements. Curr Opin Microbiol. v. 38, p. 1-9, 2017

234.RAPOPORT, M, et al. Human Infections Caused by Escherichia coli in Latin America. Antimicrob Agents Chemother. v. 60, p. 4412-3, 2016.

235.RATHER, I. A, et al. Self-medication and antibiotic resistance: Crisis, current challenges, and prevention. Saudi J Biol Sci., v. 24, p. 808-812, 2017.

236.REZAEE, M. A et al. Detection of integrons among multi- drug resistant (MDR) 
Escherichia coli strains isolated from clinical specimens in northern west of Iran. Braz. J. Microbiol., v. 42, p. 1308-1313, 2011.

237.RHOUMA, M., LETELLIER, A. Extended-spectrum $\beta$-lactamases, carbapenemases and the mor-1 gene: is there a historical link? Int J Antimicrob Agents, v. 49, p. 269-271,2017.

238.RICHTER, C.H., CUSTER, B., STEELE, J.A., WILCOX, B.A., XU, J. Intensified food production and correlated risks to human health in the Greater Mekong Subregion: a systematic review. Environ. Health., v. 14, p. 43, 2015.

239.RILEY, L.W. Pandemic lineages of extraintestinal pathogenic Escherichia coli. Clin. Microbiol. Infect., v. 20, p. 380-90, 2014.

240.ROCA, I, et al.The global threat of antimicrobial resistance: science for intervention. New Microbes New Infect., v. 6, p. 22-9, 2015.

241.ROCHA, F.R., PINTO, V.P., BARBOSA, F.C. The Spread of CTX-M-Type ExtendedSpectrum $\beta$-Lactamases in Brazil: A Systematic Review. Microb Drug Resist. v.4, p. 301$311,2016$.

242.ROCHA, F. R, et al. The spread of CTX-M-type extended-spectrum beta-lactamases in Brazil: a systematic review. Microb. Drug Res., v. 22, p. 301-311, 2016.

243.ROCHA， I.V., ANDRADE， C.A.D.N., CAMPOS， T.L., REZENDE， A.M., LEAL, N.C., VIDAL, C.F.L., XAVIER, D.E. Ciprofloxacin-resistant and extended- spectrum $\beta$ lactamase-producing Escherichia coli ST410 strain carrying the $m c r-1$ gene associated with bloodstream infection. Int J Antimicrob Agents, v. 49, p. 655-656, 2017.

244.SACRAMENTO, A.G., FERNANDES, M.R., SELLERA, F.P., MUÑOZ, M.E., VIVAS, R., DOLABELLA, SS., LINCOPAN N. Genomic analysis of MCR-1 and CTX-M-8 coproducing Escherichia coli ST58 isolated from a polluted mangrove ecosystem in Brazil. $\boldsymbol{J}$. Glob. Antimicrob. Resist., v.15, p. 288-289, 2018.

245.SACRAMENTO, A.G., FERNANDES, M.R., SELLERA, F.P., DOLABELLA, S., ZANELLA, R.C., CEREDIRA, L., LINCOPAN, N. VanA-type vancomycin-resistant Enterococcus faecium ST1336 isolated from mussels in an anthropogenically impacted ecosystem. Marine Pollution Bulletin, 2019 (in press: doi: 10.1016/ j.marpolbul. 2019 $.04 .014)$

246.SAHLY, H, et al. Extended-spectrum beta-lactamase production is associated with an increase in cell invasion and expression of fimbrial adhesins in K. pneumoniae. Antimicrob. Agents Chemother., v. 52, p. 3029-3034, 2008.

247.SALJE, J. Plasmid segregation: how to survive as an extra piece of DNA. Crit Rev Biochem Mol Biol, v. 45, p. 296 -317, 2010.

248.SALIPANTE, S.J., SENGUPTA, D.J., CUMMINGS, L.A., LAND, T.A., HOOGESTRAAT, D.R., COOKSON, B.T. Application of whole-genome sequencing for bacterial strain typing in molecular epidemiology. J Clin Microbiol., v. 53, p.1072-1079, 2015. 
249.SAMPAIO, J.L., GALES, A.C. Antimicrobial resistance in Enterobacteriaceae in Brazil: focus on $\beta$-lactams and polymyxins. Braz. J. Microbiol. v. 47, p.31-37, 2016.

250.SAN MILLAN A., PEÑA-MILLER R., TOLL-RIERA M., HALBERT Z.V., MCLEAN A.R., COOPER B.S., MACLEAN R.C. Positive selection and compensatory adaptation interact to stabilize non-transmissible plasmids. Nat Commun., v. 10, p. 5208, 2014.

251.SAROWSKA, J., FUTOMA-KOLOCH, B., JAMA-KMIECIK, A., FREJ-MADRZAK, M., KSIAZCZYK, M., BUGLA-PLOSKONSKA, G., CHOROSZY-KROL, I. Virulence factors, prevalence and potential transmission of extraintestinal pathogenic Escherichia coli isolated from different sources: recent reports. Gut. Pathog., v. 11, 2019.

252.SATO, T., OKUBO, T., USUI, M., YOKOTA, S., IZUMIYAMA, S., TAMURA, Y. Association of Veterinary Third-Generation Cephalosporin Use with the Risk of Emergence of Extended-Spectrum-Cephalosporin Resistance in Escherichia coli from Dairy Cattle in Japan. PLoS One, v. 9, p. e96101, 2014.

253.SCHAUFLER, K, et al. ESBL-plasmids carrying toxin antitoxin systems can be cured of wild type Escherichia coli using a heat technique. Gut Pathog., v. 19, p. 34, 2013.

254.SCHAUFLER, K, et al.,Genomic and functional analysis of emerging virulent and multidrug resistant E. coli lineage ST648. Antimicrob. Agents Chemother., pii: AAC.00243-19, 2019.

255.SCHWARZ, S; JOHNSON, A. P. Transferable resistance to colistin: a new but old threat. J Antimicrob Chemother. v. 71, p. 2066-70, 2016.

256.SEKI, L.M., PEREIRA, P.S., DE SOUZA CONCEIÇÃO, M., SOUZA, M.J., MARQUES, E.A., CARBALLIDO, J.M., DE CARVALHO, M.E., ASSEF, A.P., ASENSI, M.D. Molecular epidemiology of CTX-M producing Enterobacteriaceae isolated from bloodstream infections in Rio de Janeiro, Brazil: emergence of CTX-M-15. Braz. J. Infect. Dis., v. 17, p. 640-646, 2013.

257.SELLERA, F.P., FERNANDES, M.R., SARTORI, L., CARVALHO, M.P., ESPOSITO, F., NASCIMENTO C.L., DUTRA G.H., MAMIZUKA, E.M., PÉREZ-CHAPARRO, P.J., MCCULLOCH, J.A., LINCOPAN, N. Escherichia coli carrying IncX4 plasmidmediated mcr-1 and bla $a_{\mathrm{CTX}-\mathrm{M}}$ genes in infected migratory Magellanic penguins (Spheniscus magellanicus). J Antimicrob Chemother., v. 72, p. 1255-1256, 2017.

258.SELLERA, F.P., FERNANDES, M.R., MOURA, Q., LOPES, R.B., SOUZA, T.A., CERDEIRA, L., LINCOPAN, N. Draft genome sequence of a bla(CMY-2)/IncI1-harbouring Escherichia coli D:ST457 isolated from coastal benthic organisms. J. Glob. Antimicrob. Resist., v.14, p. 83-84, 2018a.

259.SELlERA, F.P., FERNANDES, M.R., MOURA, Q., CARVALHO, M.P.N., LINCOPAN, N. Extended-spectrum- $\beta$-lactamase (CTX-M)-producing Escherichia coli in wild fishes from a polluted area in the Atlantic Coast of South America. Mar. Pollut. Bull., v. 135, p.183-186, 2018b. 
269.SELLERA, F.P., LINCOPAN, N. Zooanthroponotic transmission of high-risk multidrugresistant pathogens: A neglected public health issue. J Infect Public Healt, v.12, p. 294-295, 2019.

270.SHINTANI, M., SANCHEZ, Z.K., KIMBARA, K. Genomics of microbial plasmids: classification and identification based on replication and transfer systems and host taxonomy. Front. Microbiol., v. 6, p. 242, 2015.

271.SILVA, K.C; LINCOPAN, N. Epidemiologia das beta-lactamases de espectro estendido no Brasil: impacto clínico e implicações no agronegócio. J. Bras. Patol. Med. Laboratorial, v. 2, p. 91- 99, 2012.

272.SILVA, K.C., FONTES, L.C., MORENO, A.M., ASTOLFI-FERREIRA, C.S., FERREIRA, A. J., \& LINCOPAN, N. Emergence of Extended-Spectrum-B-Lactamase CTXM-2-Producing Salmonella enterica Serovars Schwarzengrund and Agona in Poultry Farms. Antimicrob. Agents Chemeoth., v. 57, p. 3458-3459, 2013.

273.SILVA, M.M., SELLERA, F.P., FERNANDES, M.R., MOURA, Q., GARINO, F., AZEVEDO, S.S., LINCOPAN N. Genomic features of a highly virulent, ceftiofur-resistant, CTX-M-8-producing Escherichia coli ST224 causing fatal infection in a domestic cat. $J$. Glob. Antimicrob. Resist., v.15, p.252-253, 2018 a.

274.SILVA, M.M., FERNANDES, M.R., SELLERA, F.P., CERDEIRA, L., MEDEIROS, L.K.G., GARINO, F., AZEVEDO, S.S., LINCOPAN N. Multidrug-resistant CTX-M-15producing Klebsiella pneumoniae ST231 associated with infection and persistent colonization of dog. Diagn. Microbiol. Infect. Dis., v.92, p.259-261, 2018b.

275.SKOV, R. L, MONNET DL. Plasmid-mediated colistin resistance ( $m c r-1$ gene): three months later, the story unfolds. Euro Surveill. v. 21, p. 30155,2016.

276.SLATER, F.R., BAILEY, M.J., TETT, A.J., TURNER, S.L. Progress towards understanding the fate of plasmids in bacterial communities. FEMS Microbiol. Ecol., v. 66, p. 3-13, 2008.

277.SMILLIE C., GARCILLÁN-BARCIA M.P., FRANCIA M.V., ROCHA E.P., DE LA CRUZ F. Mobility of plasmids. Microbiol Mol Biol Rev., v. 74, p. 434-452, 2010.

278.SNESRUD, E, et al. A Model for Transposition of the Colistin Resistance Gene $m c r-1$ by ISApl1. Antimicrob Agents Chemother., v. 60, p. 6973-6976, 2016.

279.SUN, J, et al. Complete Nucleotide Sequence of an IncI2 Plasmid Coharboring bla $a_{\mathrm{CTX}-\mathrm{M}-}$ 55 and mcr-1. Antimicrob Agents Chemother., v. 22, p. 5014-7, 2016.

280.SUN., J, FANG, L.X., WU, Z., DENG, H., YANG, R.S., LI, X.P., LI, S.M., LIAO, X.P., FENG, Y., LIU, Y.H. Genetic Analysis of the IncX4 Plasmids: Implications for a Unique Pattern in the mcr-1 Acquisition. Sci Rep. v. 7, p. 424, 2017

281.TAYLOR, D. E. Thermosensitive nature of IncHI1 plasmid transfer. Antimicrob. Agents Chemother., v.53:2703, 2009. 
282.THOMAS, C.M. Paradigms of plasmid organization. Molec. Microbiol., v. 37, p. 485491,2000 .

283.THOMSON, C.H, et al. Yakult: a role in combating multi-drug resistant Pseudomonas aeruginosa? J. Wound Care, v. 21, p. 566-569, 2012.

284.TOLLENTINO, F.M., POLOTTO, M., NOGUEIRA, M.L., LINCOPAN, N., NEVES, P., MAMIZUKA, E.M., REMELI, G.A., DE ALMEIDA, M.T., RÚBIO, F.G., NOGUEIRA, M.C.. High prevalence of bla (CTX-M) extended spectrum beta-lactamase genes in Klebsiella pneumoniae isolates from a tertiary care hospital: first report of bla(SHV-12), bla(SHV-31), bla(SHV-38), and bla(CTX-M-15) in Brazil. Microb. Drug Resist., v. 17, p. 7-16, 2011.

285.TOLMASKY, M.E. Plasmids. In: Brenner's Encyclopedia of Genetics. 2nd.Elsevier: p. 362- 366, 2013.

286.TSAI, C. J, et al. Galleria mellonella infection models for the study of bacterial diseases and for antimicrobial drug testing. Virulence, v. 7, p. 214-29, 2016.

287.TYRRELL, J.M, et al. Genetic \& virulence profiling of ESBL-positive E. coli from nosocomial \& veterinary sources. Vet Microbiol., v. 1186, p. 37-43, 2016.

288.VALCEK, A., ROER, L., OVERBALLE-PETERSEN, S., HANSEN, F., BORTOLAIA, V., LEEKITCHAROENPHON, P., KORSGAARD, H.B., SEYFARTH, A.M., HENDRIKSEN, R.S., HASMAN, H., HAMMERUM, A.M. IncI1 ST3 and IncI1 ST7 plasmids from CTX-M-1-producing Escherichia coli obtained from patients with bloodstream infections are closely related to plasmids from E. coli of animal origin. J Antimicrob Chemother. pii:dkz199, 2019

289.VADING, M, et al. Frequent acquisition of low-virulence strains of ESBL-producing Escherichia coli in travellers. J Antimicrob Chemother., v. 71, p. 3548-3555, 2016.

290.VAN BOECKEL, T.P., BROWER, C., GILBERT, M., GRENFELL, B.T., LEVIN, S.A., ROBINSON, T.P., TEILLANT, A., LAXMINARAYAN, R. Global trends in antimicrobial use in food animals. Proc Natl Acad Sci USA, v. 112, p. 5649-54, 2015.

291.VANDECRAEN J., CHANDLER M., AERTSEN A., VAN HOUDT R. The impact of insertion sequences on bacterial genome plasticity and adaptability. Crit Rev Microbiol. v.43, p.709-730, 2017.

292.VAN SCHAIK, W. The human gut resistome. Philos Trans. R. Soc., v. 370, 2015.

293.VASQUEZ, A. M, et al. Investigation of Escherichia coli Harboring the mcr-1 Resistance Gene - Connecticut, MMWR Morb Mortal Wkly Rep., v. 65, p. 979-80, 2016.

294.VENTER, H., HENNINGSEN, M.L., BEGG, S.L. Antimicrobial resistance in healthcare, agriculture and the environment: the biochemistry behind the headlines. Essays Biochem., v. 61, p. 1-10, 2017.

295.VILA, J., SÁEZ-LÓPEZ, E., JOHNSON, J.R., RÖMLING, U., DOBRINDT, U., 
CANTÓN, R., GISKE, C.G.,NAAS, T., CARATTOLI, A., MARTÍNEZ-MEDINA, M., BOSCH, J., RETAMAR, P., RODRÍGUEZ-BAÑO, J.,BAQUERO, F., SOTO, S.M. Escherichia coli: an old friend with new tidings. FEMS Microbiol Rev., v. 40, p. 437-463, 2016.

296.VILLA, L., GARCÍA-FERNÁNDEZ, A., FORTINI, D., CARATTOLI, A. Replicon sequence typing of IncF plasmids carrying virulence and resistance determinants. $J$. Antimicrob. Chemother., v. 65, p. 2518-2529, 2010.

297.VINUÉ, L, et al. Prevalence and diversity of extended-spectrum beta-lactamases in faecal Escherichia coli isolates from healthy humans in Spain. Clin Microbiol Infect., v. 15, p. 954$7,2009$.

298.WANG, J., STEPHAN, R., POWER, K., YAN. Q., HÄCHLER, H., FANNING, S. Nucleotide sequences of 16 transmissible plasmids identified in nine multidrug-resistant Escherichia coli isolates expressing an ESBL phenotype isolated from food-producing animals and healthy humans. J Antimicrob Chemother., p.2658-2668, 2014.

299.WANG Q, et al. Expanding landscapes of the diversified $m c r$-1-bearing plasmid reservoirs. Microbiome. v. 5: 70, 2017.

300.WANG, X., WANG, Y., ZHOU, Y., LI, J., YIN, W., WANG, S., ZHANG, S., SHEN, J., SHEN, Z., WANG, Y. Emergence of a novel mobile colistin resistance gene, $m c r-8$, in NDMproducing Klebsiella pneumoniae. Emerg. Microbes Infect., v.7, p.122, 2018.

301WARREN, R.E., ENSOR, V.M., O'NEILL, P., BUTLER, V., TAYLOR, J., NYE, K., HARVEY, M., LIVERMORE, D.M., WOODFORD, N., HAWKEY, P.M. Imported chicken meat as a potential source of quinolone-resistant Escherichia coli producing extendedspectrum beta-lactamases in the UK. J. Antimicrob. Chemother. v.61, p.504-508, 2008

302.WORLD HEALTH ORGANISATION ANTIMICROBIAL RESISTANCE: WHO publishes list of bacteria for which new antibiotics are urgently needed, 2017. (Acesso em 10 de março de 2019); https://www.who.int/en/news-room/detail/27-02-2017-who-publishes-listof-bacteria-for-which-new-antibiotics-are-urgently-needed.

303.WOERTHER, P. L, et al. Trends in human fecal carriage of extended-spectrum- $\beta$ lactamases in the community: toward of globalizationf of CTX-M. Clin.Microb.Rev., v.26, p.744-758, 2013a.

304.WOERTHER, P.L, et al. Characterization of fecal extended- spectrum- $\beta$-lactamaseproducing Escherichia coli in a remote community during a long time period. Antimicrob Agents Chemother., v. 57, p. 5060-6, 2013 b.

305.WONG, M.H., KAN, B., CHAN, E.W., YAN, M., CHEN, S. IncI1 Plasmids Carrying Various blaCTX-M Genes Contribute to Ceftriaxone Resistance in Salmonella entérica Serovar Enteritidis in China. Antimicrob Agents Chemother. v.60, p.982-9, 2015.

306.WOZNIAK, R.A., WALDOR, M.K. Integrative and conjugative elements: mosaic mobile genetic elements enabling dynamic lateral gene flow. Nat Rev Microbiol. v.8, p.552-63, 2010. 
307.WRIGHT, G.D. The antibiotic resistome: the nexus of chemical and genetic diversity. Nat. Ver. Microbiol., v.5, p.175-86, 2007.

308.YANG, Q.E., WALSH, T.R. Toxin-antitoxin systems and their role in disseminating and maintaining antimicrobial resistance. FEMS Microbiol Rev., v. 41, p. 343-353, 2017.

309.YANG, Y.Q., LI, Y.X., LEI, C.W., ZHANG, A.Y., WANG, H.N. Novel plasmidmediated colistin resistance gene mcr-7.1 in Klebsiella pneumoniae. J. Antimicrob. Chemother., v. 73, p. 1791-1795, 2018. 


\title{
Silent dissemination of colistin-resistant Escherichia coli in South America could contribute to the global spread of the $m c r-1$ gene
}

\author{
MR Fernandes ${ }^{1}$, Q Moura $^{2}$, L Sartori ${ }^{1}$, KC Silva ${ }^{3}$, MP Cunha ${ }^{3}$, F Esposito ${ }^{1}$, R Lopes ${ }^{2}$, LK Otutumi ${ }^{4}$, DD Gonçalves ${ }^{4}$, M Dropa ${ }^{5}$ \\ , MH Matté ${ }^{5}$, DF Monte ${ }^{6}$, M Landgraf ${ }^{6}$, GR Francisco ${ }^{7}$, MF Bueno ${ }^{7}$, D de Oliveira Garcia ${ }^{7}, \mathrm{~T} \mathrm{Knöbl}^{3}, \mathrm{AM} \mathrm{Moreno}^{3}, \mathrm{~N}^{\mathrm{L}}$ Lincopan $^{1}$ \\ 1. Department of Clinical Analysis, School of Pharmacy, Universidade de São Paulo, São Paulo, Brazil \\ 2. Department of Microbiology, Institute of Biomedical Sciences, Universidade de São Paulo, São Paulo, Brazil \\ 3. School of Veterinary Medicine, Universidade de São Paulo, São Paulo, Brazil \\ 4. Department of Veterinary Preventive Medicine, School of Veterinary Medicine, Universidade Paranaense, Paraná, Brazil \\ 5. Public Health Laboratory, School of Public Health, Universidade de São Paulo, São Paulo, Brazil \\ 6. Food and Experimental Nutrition Department, School of Pharmacy \& Food Research Center, Universidade de São Paulo, São \\ Paulo, Brazil \\ 7. Center of Bacteriology, Instituto Adolfo Lutz, São Paulo, Brazil
}

Correspondence: Nilton Lincopan (lincopan@usp.br)

Citation style for this article:

Fernandes MR, Moura Q, Sartori L, Silva KC, Cunha MP, Esposito F, Lopes R, Otutumi LK, Gonçalves DD, Dropa M, Matté MH, Monte DF, Landgraf M, Francisco GR, Bueno MF, de Oliveira Garcia D, Knöbl T, Moreno AM, Lincopan N. Silent dissemination of colistin-resistant Escherichia coli in South America could contribute to the global spread of the mcr-1 gene. Euro Surveill. 2016;21(17): pii=30214. DOI: http://dx.doi.org/10.2807/1560-7917.ES.2016.21.17.30214

During a Brazilian multicentric antimicrobial resistance surveillance study, colistin resistance was investigated in 4,620 Enterobacteriaceae isolated from human, animal, food and environmental samples collected from 2000 to 2016 . We present evidence that mcr-1-positive Escherichia coli has been emerging in South America since at least 2012, supporting a previous report on the possible acquisition of $\mathrm{mcr}$-1-harbouring $E$. coli by European travellers visiting Latin American countries.

We present evidence that mcr-1-harbouring Escherichia coli has been occurring in food-producing animals in Brazil since at least 2012.

\section{Screening Enterobacteriaceae isolates for potential colistin resistance and the $m c r-1$ gene}

Between 2000 and 2016, a total of 4,620 Enterobacteriaceae isolates were collected in Brazil, as part of different surveillance projects on carbapenemase- and/or extended-spectrum beta-lactamases (ESBL)-producing Gram-negative bacteria important to human and veterinary medicine [1-4]. Within this Brazilian multicentric antimicrobial resistance surveillance study, we hereby also investigate colistin resistance.

The 4,620 isolates were screened using MacConkey agar plates supplemented with colistin (2 mg/L). A total of 515 isolates, which had grown on the screening plates were obtained. These originated from food-producing animals (227 isolates), chicken feed (4 isolates), companion (9 isolates) and non-companion animals (24 isolates), humans (137 isolates), food (102 isolates) and the environment (12 isolates). The 515 isolates were further tested for susceptibility to colistin by agar dilution and/or broth microdilution method, whereby a minimum inhibitory concentration (MIC) > 2 $\mathrm{mg} / \mathrm{L}$ was considered indicative of colistin resistance according to the European Committee on Antimicrobial Susceptibility Testing (EUCAST) [5]. Isolates were also subjected to polymerase chain reaction (PCR) to check whether respective strains harboured the $\mathrm{mcr}$-1 gene [6], which if present was sequenced (Table).

The $m c r-1$ gene was detected in 16 commensal $E$. coli strains exhibiting colistin MICs from 1 to $16 \mathrm{mg} / \mathrm{L}$ $\left(\mathrm{MIC}_{50}=8 \mathrm{mg} / \mathrm{L}\right)$. Two of the mcr-1-positive E. coli strains were found in faecal samples collected in 2012 from healthy pigs in farms located in Santa Catarina and Minas Gerais states. One of these two isolates was susceptible for colistin $(\mathrm{MIC}=1 \mathrm{mg} / \mathrm{L})$. The remaining 14 $m c r$-1-harbouring $E$. coli strains originated from faecal samples of healthy chickens, which had been gathered in 2013 from farms located in Paraná, São Paulo and Minas Gerais states. All 14 isolates from chickens had a $\mathrm{MIC} \geq 8 \mathrm{mg} / \mathrm{L}$.

\section{Relationships between $m c r$-1-positive} isolates, and testing for extended-spectrum beta-lactamases

The sequences of the $16 \mathrm{mcr}$-1-positive $E$. coli strains were phylogenetically analysed [7], revealing that 11 


\section{FIGURE 1}

Pulsed-field gel electrophoresis (PFGE) and antimicrobial resistance chraracteristics of $m$ cr-1-positive Escherichia coli strains isolated from faeces of healthy livestock, Brazil, 2012-2013

A. Xbal PFGE of MCR-1-positive E. coli strains isolated from faeces of healthy livestock

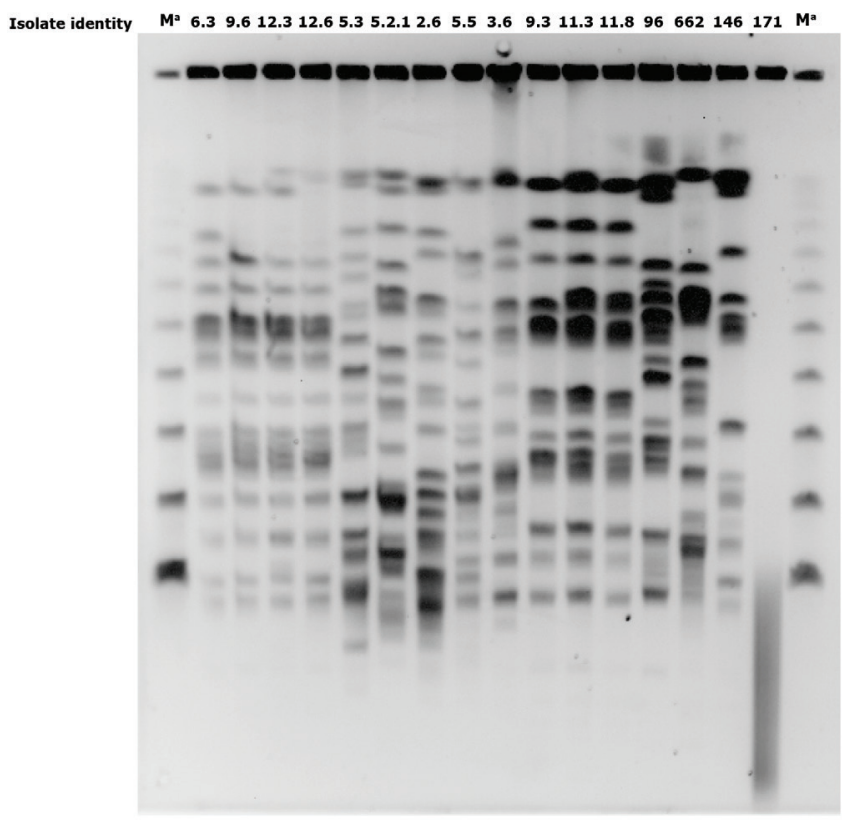

B. Relationship between isolates obtained after Xbal PFGE and antimicrobial resistance

Colistin MIC

PFGE

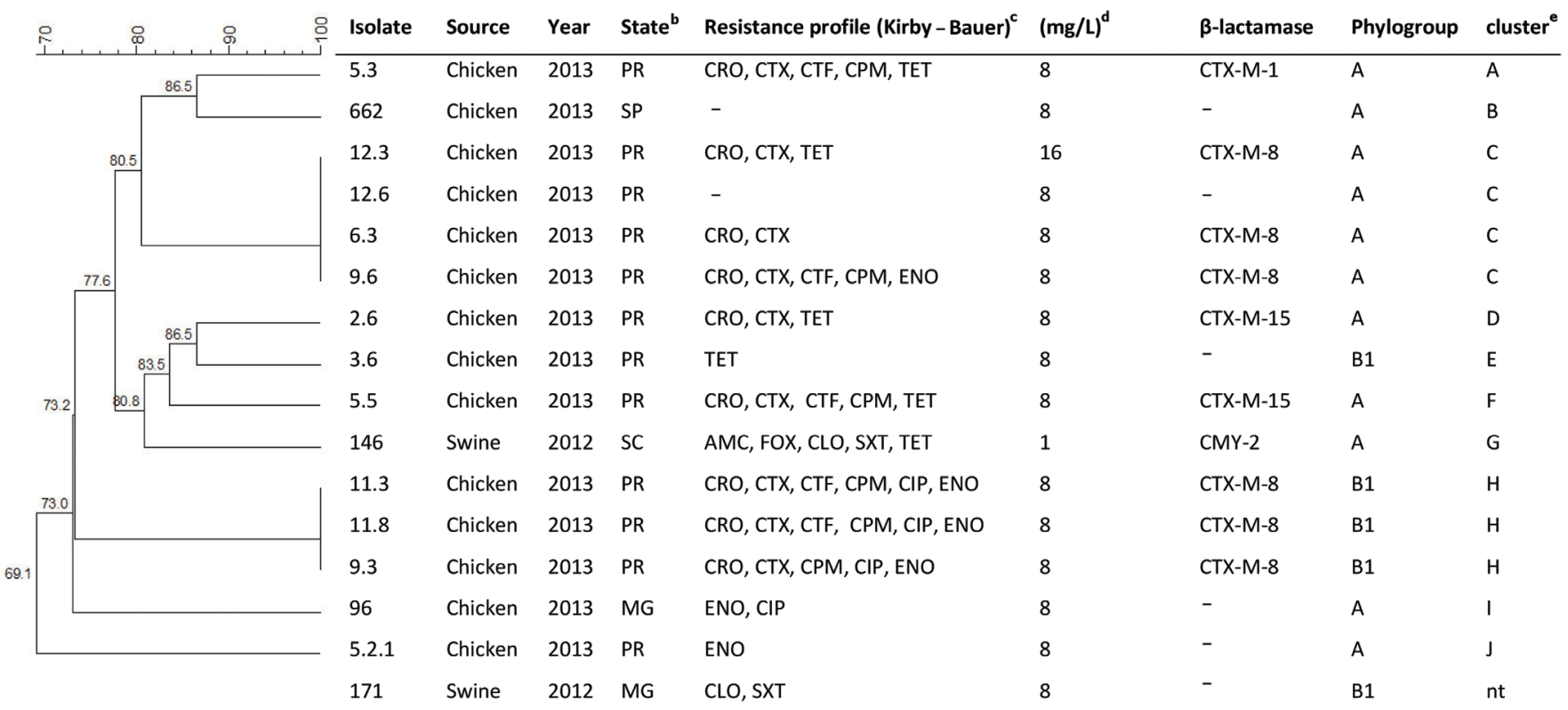

MIC: minimum inhibitory concentration; nt: non typeable by PFGE.

GenBank accession number for mcr-1 genes identified in this study: KU750813, KU928239-42, KU935441-9, KXo1152-1.

a The marker (M) used was the Lambda ladder $0.05-1 \mathrm{Mb}$, Bio-Rad. Separation of fragments was carried out at $6 \mathrm{~V} / \mathrm{cm}$ at $14^{\circ} \mathrm{C}$ for $20 \mathrm{~h}$, with linear pulse time of $3.51 \mathrm{~S}$ to 30.825 .

b The states were as follow: MG: Minas Gerais state (South-east Brazil); PR: Paraná state (South); SC: Santa Catarina state (South); SP: São Paulo (South-east).

c The antimicrobial susceptibility was evaluated by disc diffusion assay. Extended-spectrum beta-lactamase (ESBL) production was investigated by using a double-disc synergy test (DDST) [5,23,24]. AMC: amoxicillin/clavulanic acid; CAZ: ceftazidime; CFX: cefoxitin; CIP: ciprofloxacin; CLO: chloramphenicol; CPM: cefepime; CRO: ceftriaxone; CTF: ceftiofur; CTX: cefotaxime; ENO: enrofloxacin; FOS: fosfomycin; GEN: gentamicin; SXT: trimethoprim/sulfamethoxazole; TET: tetracycline.

d MICs were determined according to the European Committee on Antimicrobial Susceptibility Testing (EUCAST) [5,25]. Colistin resistance was defined as a colistin MIC 2 $\mathrm{mg} / \mathrm{L}$, according to EUCAST clinical breakpoints [5].

e PFGE patterns were analysed using the Dice similarity with coefficient optimisation set at $1 \%$ and tolerance at $2 \%$ (BioNumerics software; Applied Maths, Kortrijk, Belgium). 


\section{FIGURE 2}

Geographical distribution of mcr-1-positive Escherichia coli isolates reported from South America, 2012-2016

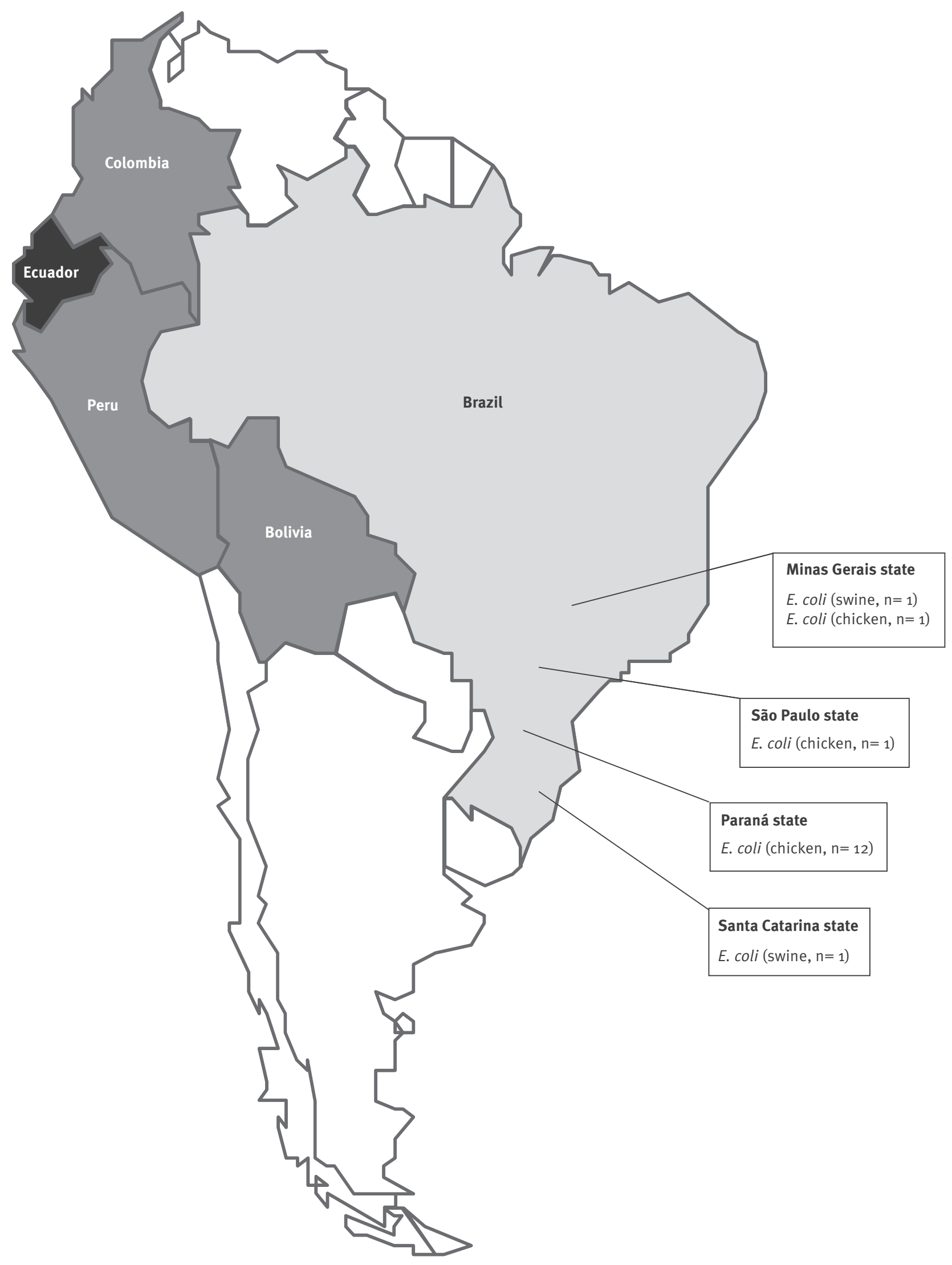

A light grey colour is used for Brazil, where this study was conducted. The dark grey colour indicates countries (Bolivia, Colombia and Peru) visited between November 2012 and November 2013, by unrelated Dutch travellers, for whom acquisition of faecal colonisation and carriage with MCR-1 and extended-spectrum beta-lactamase (ESBL)-producing E. coli was shown one to two weeks after their return to the Netherlands [12]. A dark grey colour is used for Ecuador, where subsequent to the identification of a human mcr-1-positive isolate, a sequence was deposited in GenBank in March 2016 (GenBank accession number: KU886144.1). 
Results of screening Enterobacteriaceae isolates from different sources by culture with colistin and presence of the $m c r-1$ gene in the screened isolates, Brazil, 2000-2016 ( $\mathrm{n}=4,620$ isolates screened)

\begin{tabular}{|c|c|c|c|c|c|}
\hline \multicolumn{2}{|l|}{ Source } & $\begin{array}{l}\text { Years of } \\
\text { isolate } \\
\text { collection }\end{array}$ & $\begin{array}{l}\text { Enterobacteriaceae } \\
\text { isolates tested } \\
n\end{array}$ & $\begin{array}{c}\text { Enterobacteriaceae isolates } \\
\text { with growth on screening } \\
\text { plates ( } 2 \mathrm{mg} / \mathrm{L} \text { colistin) } \\
n^{\mathrm{b}}\end{array}$ & $\begin{array}{c}\text { Isolates positive for } \\
\text { mcr-1 } \\
N \text { (\% of isolates } \\
\text { screened })^{c}\end{array}$ \\
\hline \multirow{6}{*}{ Food-producing animals } & Chicken & $2003-2015$ & 280 & 113 & $14(5.0)$ \\
\hline & Swine & $2012-2014$ & 113 & 79 & $2(1.8)$ \\
\hline & Cattle & $2014-2015$ & 158 & 22 & $\mathrm{o}(\mathrm{o})$ \\
\hline & Goat & 2013 & 7 & 1 & $\mathrm{o}(\mathrm{o})$ \\
\hline & Ostriches & 2015 & 9 & 2 & o (o) \\
\hline & Buffalo & 2010 & 36 & 10 & $\mathrm{o}(\mathrm{o})$ \\
\hline Chicken feed & - & $2000-2014$ & 8 & 4 & $\mathrm{o}(0)$ \\
\hline \multirow{2}{*}{ Companion animals } & Cats & 2013 & 4 & 0 & o (o) \\
\hline & Dogs & 2013 & 51 & 9 & $\mathrm{o}(\mathrm{o})$ \\
\hline \multirow{5}{*}{ Non-Companion animals } & Horse & 2013 & 13 & 3 & $\mathrm{o}(\mathrm{o})$ \\
\hline & Rodents & $2013-2014$ & 14 & 13 & $\mathrm{o}(\mathrm{o})$ \\
\hline & Turtle & 2015 & 21 & 8 & $\mathrm{o}(\mathrm{o})$ \\
\hline & $\begin{array}{c}\text { Urban } \\
\text { pigeons }\end{array}$ & $2015-2016$ & 36 & 0 & o (o) \\
\hline & $\begin{array}{c}\text { Urban } \\
\text { waterfowl }\end{array}$ & $2012-2014$ & 75 & 0 & o (o) \\
\hline $\begin{array}{l}\text { Human infection/ } \\
\text { colonisation }\end{array}$ & - & $2004-2016$ & 3,591 & 137 & o (o) \\
\hline \multirow{5}{*}{ Food } & $\begin{array}{c}\text { Chicken } \\
\text { meat }\end{array}$ & 2013 & 42 & 22 & o (o) \\
\hline & Swine meat & $2012-2014$ & 113 & 79 & o (o) \\
\hline & Cabbage & 2016 & 2 & 0 & o (o) \\
\hline & Lettuce & 2016 & 2 & 0 & o (o) \\
\hline & Spinach & 2016 & 1 & 1 & o (o) \\
\hline \multirow{3}{*}{ Environment } & Lake & $2012-2013$ & 20 & 2 & o (o) \\
\hline & River & 2011 & 3 & 3 & o (o) \\
\hline & Sewage & $2009-2013$ & 21 & 7 & $\mathrm{o}(\mathrm{o})$ \\
\hline Total & - & - & 4,620 & 515 & $16(0.3)$ \\
\hline
\end{tabular}

a Isolates originated from previous surveillance studies of carbapenemase- and/or extended-spectrum beta-lactamases (ESBL)-producing Gram-negative bacteria in food, food-producing animals (faecal samples from healthy animals), chicken feed, companion and noncompanion animals (faecal samples from healthy animals), environment and human patients from healthcare settings (27 faecal samples from colonised individuals and 3,564 clinical cultures from infections), all collected in Brazil between 2000 and 2016 [1-4].

${ }^{b}$ Isolates were screened for potential colistin resistance using MacConkey agar plates supplemented with colistin (2 mg/L).

c Enterobacteriaceae isolates with growth on screening plates were subjected to $m c r-1$ polymerase chain reaction and sequencing [6].

strains belonged to the phylogroup $A$ and five to the phylogroup B1. Clonal relatedness of the strains were further determined by Xbal pulsed-field gel electrophoresis (PFGE) (www.cdc.gov/pulsenet/). PFGE differentiated $m c r$-1-positive $E$. coli isolates into 10 distinct pulsotypes (named $A$ to J), which clustered into two major groups, $\mathrm{C}(\mathrm{n}=4)$ and $\mathrm{H}(\mathrm{n}=3)$ (Figure 1$)$.

The 16 mcr-1-positive isolates were additionally tested for the production of extended-spectrum beta-lactamases (ESBLs) by using a double-disc synergy test (DDST) as well as for the presence of ESBL- and plasmid-mediated AmpC (pAmpC) beta-lactamase genes $[1,6]$.
Most ( $\mathrm{n}=9$ ) $m c r-1$-positive isolates exhibited resistance to human and/or veterinary cephalosporins. In this regard, such isolates harboured $b l a_{\text {СTX-M-1 }}, b l a_{\text {СTX-M-8 }}$ and/or bla $a_{\text {CTX-M-15 }}$ ESBL genes, and one isolate carried the pAmpC bla ${ }_{\mathrm{CMY}-2}$ gene. On the other hand, all isolates carrying the $\mathrm{mcr}-1$ gene belonged to low-virulence E. coli phylogroups (i.e. A and B1 as described above).

\section{Discussion}

The plasmid-mediated colistin (polymyxin E) resistance mechanism MCR-1 was first described in Enterobacteriaceae isolated from animals, food and human beings in China [6]. Since, and as summarised by Skov and Monnet [8], MCR-1 has also been reported to occur in other countries in Asia, Europe and North America. Recent descriptions from Egypt [9], Italy [10] 
and Spain [11] further denote dissemination of the mechanism, while identifications of $m c r-1$ positive strains in imported food, urban rivers and travellers [12-16] highlight the potential for MCR-1 to continue spreading. In addition, co-production of ESBLs or carbapenemases by $\mathrm{mcr}$-1-harbouring Enterobacteriaceae has now been documented [12,13,15-18].

We report $m c r$-1-positive $E$. coli isolates from foodproducing animals in the southern (Santa Catarina and Paraná states) and south-eastern (São Paulo and Minas Gerais states) regions of Brazil (Figure 2). Interestingly, in most of these isolates (9 of 16), E. coli strains coproduced CTX-M-type ESBLs.

Our findings moreover suggest that $m c r-1$-harbouring $E$. coli strains have been present in South America since at least 2012, supporting the results of a previous study on the possible acquisition of mcr-1-carrying $E$. coli by European travellers visiting this continent (Figure 2) [12]. In this previous prospective study, the carriage of multiresistant bacteria after travel (COMBAT) consortium had shown that unrelated Dutch travellers to Bolivia, Colombia and Peru between November 2012 and November 2013 had become carriers of/colonised with MCR-1 and ESBL-producing E. coli one to two weeks after their return to the Netherlands [12].

Recently the $m c r-1$ gene has also been identified in another Latin American country, Ecuador, whereby a respective sequence from a human clinical $E$. coli isolate was submitted to GenBank (GenBank accession number: KU886144.1) in March 2016. Therefore, hospital laboratories worldwide should be aware of the possibility of MCR-1 in Enterobacteriaceae isolates resistant to polymyxins from patients living in or returning from Latin American countries.

That $E$. coli with plasmid-mediated MCR-1 are found in Brazil is also relevant for medical centres in this country, where the emergence and dissemination of multidrug-resistant pathogens, which is associated with high rates of treatment failure, have led to high use of polymyxins, mainly in intensive care units [19]. There, this class of antimicrobial agents represents the main therapeutic option for treating severe 'superbug' infections, particularly Pseudomonas aeruginosa, Acinetobacter baumannii and Klebsiella pneumoniae producing SPM1, OXA-23 or KPC-2 carbapenemases, which are highly prevalent in most Brazilian hospitals [19]. On a positive note however, our study did not find mcr-1-positivity in any of the human isolates screened, which is consistent with the very low background carriage of MCR-1 in humans, as described previously [6,12-14].

Our result that the $m c r-1$ gene occurs in Brazilian livestock is a cause for concern in terms of the global contribution of Brazil to national and international movement of people and products, as this could contribute to the acceleration of the worldwide spread of the $\mathrm{mcr}-1$ gene. Indeed, with a population of 205 million inhabitants,
Brazil has continental proportions and is the biggest country in Latin America. Furthermore, in the agribusiness it is the third producer of chicken meat (only after the United States and China) and the largest exporter of this product [20]. In this regard, colistin sulphate is widely used in animal feed as a growth promoter in Brazilian livestock, mainly in pigs and poultry, supporting a link between the agricultural use of colistin and colistin resistance [21].

Finally, the identification of a colistin-susceptible $E$. coli strain carrying the $m c r-1$ gene, in this study, suggests that $m c r$-1-positive isolates may be difficult to detect if the $m c r-1$ gene is only tested for in colistin resistant isolates. This may contribute to the silent dissemination of $m c r-1$ harbouring strains. In fact, many MCR-1 producers are known to exhibit low level of resistance to colistin (i.e. 4-16 mg/L) $[6,8-14,16,22]$.

In summary, since MCR-1-producing strains have already become established in South America, we emphasise the need for continuous local surveillance programmes to identify the risk to human health. To reduce this risk, the authors suggest that colistin should only be used for treatment of clinical infectious diseases and no longer for animal production, in order to prevent the wide spread of MCR-1-producing bacteria, achieving the principles of responsible use of antibiotics.

\section{Erratum}

The term ' $m c r-1$ ' had been mistyped as ' $m r c-1$ ' on several occasions and this was corrected on 02 May 2016.

\section{Acknowledgements}

FAPESP (Fundação de Amparo à Pesquisa do Estado de São Paulo) and CNPq (Conselho Nacional de Desenvolvimento Científico e Tecnológico) research grants are gratefully acknowledged. NL is a research fellow of CNPq. We thank Drs Jean-Yves Madec and Marisa Haenni (Anses-Lyon, France) for providing the MCR-1-positive control strain.

\section{Conflict of interest}

None declared.

\section{Authors' contributions}

MRF, QM, LS, FE, RL, LKO, DDG, MD, MHM, DFMM, ML, DdOG, TK and AMM collected the data and samples, MRF, QM, LS, KCS, MPVC, FE, RL, MD, GRF, MFCB and NL performed the microbiological and molecular analysis, MRF, QM, KCS, FE, MD, DdOG, TK and NL participated in drafting the manuscript, NL coordinated and edited the manuscript.

\section{References}

1. Dropa M, Lincopan N, Balsalobre LC, Oliveira DE, Moura RA, Fernandes MR, et al. Genetic background of novel sequence types of CTX-M-8- and CTX-M-15-producing Escherichia coli and Klebsiella pneumoniae from public wastewater treatment plants in São Paulo, Brazil. Environ Sci Pollut Res Int. 
2016;23(5):4953-8. DOI: 10.1007/S11356-016-6079-5 PMID: 26782324

2. Pereira GH, Garcia DO, Mostardeiro M, Ogassavara CT, Levin AS. Spread of carbapenem-resistant Klebsiella pneumoniae in a tertiary hospital in Sao Paulo, Brazil.J Hosp Infect. 2011;79(2):182-3. DOI: 10.1016/j.jhin.2011.05.023 PMID: 21798628

3. Silva KC, Moreno M, Cabrera C, Spira B, Cerdeira L, Lincopan $\mathrm{N}$, et al. First Characterization of CTX-M-15-Producing Escherichia coli Strains Belonging to Sequence Type (ST) 410 , ST224, and ST1284 from Commercial Swine in South America. Antimicrob Agents Chemother. 2016;60(4):2505-8. DOI: 10.1128/AAC.02788-15 PMID: 26824955

4. Casella T, Rodríguez MM, Takahashi JT, Ghiglione B, Dropa $M$, Assunção $E$, et al. Detection of blaCTX-M-type genes in complex class 1 integrons carried by Enterobacteriaceae isolated from retail chicken meat in Brazil. Int J Food Microbiol. 2015;197:88-91. DOI: 10.1016/j.ijfoodmicro.2014.12.001 PMID: 25576985

5. European Committee on Antimicrobial Susceptibility Testing (EUCAST). Breakpoint tables for interpretation of MICs and zone diameters. Version 6.0, 2016. Växjö: EUCAST. Available from: http://www.eucast.org/clinical_breakpoints/

6. Liu YY, Wang Y, Walsh TR, Yi LX, Zhang R, Spencer J, et al. Emergence of plasmid-mediated colistin resistance mechanism MCR-1 in animals and human beings in China: a microbiological and molecular biological study. Lancet Infect Dis. 2016;16(2):161-8. DOI: 10.1016/S1473-3099(15)00424-7 PMID: 26603172

7. Clermont O, Bonacorsi S, Bingen E. Rapid and simple determination of the Escherichia coli phylogenetic group. Appl Environ Microbiol. 2000;66(10):4555-8. DOI: 10.1128/ AEM.66.10.4555-4558.2000 PMID: 11010916

8. Skov RL, Monnet DL. Plasmid-mediated colistin resistance (mcr-1 gene): three months later, the story unfolds. Euro Surveill. 2016;21(9):30155. DOI: 10.2807/1560-7917. ES.2016.21.9.30155 PMID: 26967914

9. Elnahriry SS, Khalifa HO, Soliman AM, Ahmed AM, Hussein AM, Shimamoto T, et al. Emergence of plasmid-mediated colistin resistance gene mcr-1 in a clinical Escherichia coli isolate from Egypt. Antimicrob Agents Chemother. 2016;60(5):3249-50. DOI: 10.1128/AAC.00269-16 PMID: 26953204

10. Cannatelli A, Giani T, Antonelli A, Principe L, Luzzaro F, Rossolini GM. First detection of the mcr-1 colistin resistance gene in Escherichia coli in Italy. Antimicrob Agents Chemother. 2016;60(5):3257-8. DOI: 10.1128/AAC.00246-16 PMID: 26976865

11. Prim N, Rivera A, Rodríguez-Navarro J, Español M, Turbau M, Coll $P$, et al. Detection of $\mathrm{mcr}-1$ colistin resistance gene in polyclonal Escherichia coli isolates in Barcelona, Spain, 2012 to 2015. Euro Surveill. 2016;21(13):30183. DOI: 10.2807/15607917.ES.2016.21.13.30183 PMID: 27055477

12. Arcilla MS, van Hattem JM, Matamoros S, Melles DC, Penders J, de Jong MD, et al. , COMBAT consortium. Dissemination of the mcr-1 colistin resistance gene.Lancet Infect Dis. 2016;16(2):147-9. DOI: 10.1016/S1473-3099(15)00541-1 PMID: 26711361

13. Du H, Chen L, Tang YW, Kreiswirth BN. Emergence of the mcr-1 colistin resistance gene in carbapenem-resistant Enterobacteriaceae.Lancet Infect Dis. 2016;16(3):287-8. DOI: 10.1016/S1473-3099(16)00056-6 PMID: 26842776

14. Kluytmans-van den Bergh MF, Huizinga P, Bonten MJ, Bos M, De Bruyne K, Friedrich AW, et al. Presence of mcr-1-positive Enterobacteriaceae in retail chicken meat but not in humans in the Netherlands since 2009. Euro Surveill. 2016;21(9):30149. DOI: 10.2807/1560-7917.ES.2016.21.9.30149 PMID: 26967540

15. Haenni M, Poirel L, Kieffer N, Châtre P, Saras E, Métayer $V$, et al. Co-occurrence of extended spectrum $\beta$ lactamase and MCR-1 encoding genes on plasmids. Lancet Infect Dis. 2016;16(3):281-2. DOI: 10.1016/S1473-3099(16)00007-4 PMID: 26774244

16. Hasman H, Hammerum AM, Hansen F, Hendriksen RS, Olesen $\mathrm{B}$, Agers $\emptyset \mathrm{Y}$, et al. Detection of mcr-1 encoding plasmidmediated colistin-resistant Escherichia coli isolates from human bloodstream infection and imported chicken meat, Denmark 2015. Euro Surveill. 2015;20(49):30085. DOI: 10.2807/1560-7917.ES.2015.20.49.30085 PMID: 26676364

17. Falgenhauer L, Waezsada SE, Yao Y, Imirzalioglu C, Käsbohrer $A$, Roesler U, et al. , RESET consortium. Colistin resistance gene mcr-1 in extended-spectrum $\beta$-lactamase-producing and carbapenemase-producing Gram-negative bacteria in Germany. Lancet Infect Dis. 2016;16(3):282-3. DOI: 10.1016/S14733099(16)00009-8 PMID: 26774242

18. Zurfuh K, Poirel L, Nordmann P, Nüesch-Inderbinen

$M$, Hächler $H$, Stephan R. Occurrence of the Plasmid-Borne mcr-1 Colistin Resistance Gene in Extended-Spectrum- $\beta$-Lactamase-Producing Enterobacteriaceae in River Water and Imported Vegetable Samples in Switzerland.Antimicrob Agents Chemother. 2016;60(4):2594-5. DOI: 10.1128/AAC.00066-16 PMID: 26883696

19. Rossi F. The challenges of antimicrobial resistance in Brazil. Clin Infect Dis. 2011;52(9):1138-43. DOI: 10.1093/cid/cir120 PMID: 21467020

20. United States International Trade Commission (USITC). Brazil: Competitive Factors in Brazil Affecting U.S. and Brazilian Agricultural Sales in Selected Third Country Markets. Publication 4310. Washington, DC: USITC; 2012. Available online: https://www.usitc.gov/publications/332/pub4310.pdf

21. Morales AS, Fragoso de Araújo J, de Moura Gomes VT, Reis Costa AT, dos Prazeres Rodrigues D, Porfida Ferreira TS, et al. Colistin resistance in Escherichia coli and Salmonella enterica strains isolated from swine in Brazil. ScientificWorldJournal. 2012;2012:109795. DOI: 10.1100/2012/109795

22. Nordmann P, Poirel L. Plasmid-mediated colistin resistance: an additional antibiotic resistance menace.Clin Microbiol Infect. 2016;S1198-743X(16)30024-6.PMID: 27021419

23. Clinical and Laboratory Standard Institute (CLSI). Performance Standards for Antimicrobial Susceptibility Testing; Seventeenth Informational Supplement. Wayne,PA: CLSI; 2007. CLSI document M100-S17.

24. European Committee on Antimicrobial Susceptibility Testing (EUCAST). EUCAST guidelines for detection of resistance mechanisms and specific resistance of clinical and/or epidemiological importance. Version 1.0, 2013. Växjö: EUCAST. Available from: http://www.eucast.org/

25. European Committee on Antimicrobial Susceptibility Testing (EUCAST). Media preparation for EUCAST disk diffusion testing and for determination of MIC values by the broth microdilution method. Version 4.0, 2014. Växjö: EUCAST. Available from: http://www.eucast.org/

\section{License and copyright}

This is an open-access article distributed under the terms of the Creative Commons Attribution (CC BY 4.0) Licence. You may share and adapt the material, but must give appropriate credit to the source, provide a link to the licence, and indicate if changes were made.

This article is copyright of the authors, 2016. 


\title{
First Report of the Globally Disseminated IncX4 Plasmid Carrying the mor-1 Gene in a Colistin-Resistant Escherichia coli Sequence Type 101 Isolate from a Human Infection in Brazil
}

\author{
Miriam R. Fernandes, ${ }^{a}$ John A. McCulloch, ${ }^{a}$ Marco A. Vianello, ${ }^{b}$ Quézia Moura, ${ }^{c}$ Paula J. Pérez-Chaparro, ${ }^{a}$ Fernanda Esposito, ${ }^{a}$ \\ Luciana Sartori, ${ }^{a}$ Milena Dropa, ${ }^{d}$ Maria H. Matté, ${ }^{d}$ Débora P. A. Lira, ${ }^{b}$ Elsa M. Mamizuka, ${ }^{a}$ (D) Nilton Lincopan ${ }^{\mathrm{a}, \mathrm{c}}$ \\ Department of Clinical Analysis, Faculty of Pharmaceutical Sciences, University of São Paulo, São Paulo, Brazila; Hospital de Guarnição de Natal, Brazilian Army, Natal, \\ Brazil $^{\text {b; }}$ Department of Microbiology, Institute of Biomedical Sciences, University of São Paulo, São Paulo, Brazilc; School of Public Health, University of São Paulo, São Paulo, \\ Brazil $^{d}$
}

A colistin-resistant Escherichia coli strain was recovered from a patient with a diabetic foot infection in Brazil. Whole-genome analysis revealed that the $E$. coli isolate belonged to the widespread sequence type (ST) 101 and harbored the $m c r-1$ gene on an IncX4 plasmid that was highly similar to $\mathbf{m c r}$-1-bearing IncX4 plasmids that were recently identified in Enterobacteriaceae from food, animal, and human samples recovered on different continents. These results suggest that self-transmissible IncX4-type plasmids may represent promiscuous plasmids contributing to the intercontinental spread of the $m c r-1$ gene.

Tisis he plasmid-mediated colistin resistance mechanism MCR-1 has become a great challenge to public health worldwide. In fact, since its initial identification in Enterobacteriaceae strains (mostly Escherichia coli) isolated from animals, food, and humans in China (1), MCR-1 has also been reported in other countries in Asia, Africa, Europe, and North America (2). In South America, E. coli harboring the $m c r-1$ gene has been present in food-producing animals since at least 2012 (3), being recently identified in human clinical samples from Argentina (4). We hereby report the first description (to our knowledge) of MCR-1 in a human E. coli isolate from Brazil.

In early 2016, a man in his late 60s with a medical history of type 2 diabetes mellitus, atrial fibrillation, obesity, dyslipidemia, and hypertension was admitted to a private hospital in northeastern Brazil with a 2-month history of a right calcaneal ulcer (informed consent was obtained from this patient). The patient underwent debridement with fasciotomy of necrosed tissue. Wound cultures taken during debridement were negative for aerobic bacteria, and empirical intravenous antibiotic therapy with ceftriaxone and clindamycin was initiated. Following 14 days of antibiotic therapy, the patient was discharged with clinical improvement. Nine days later, however, he returned to the hospital with worsened symptoms, and the combined therapy of ceftriaxone with clindamycin was restarted. As the patient's condition was deteriorating, the treatment was changed to piperacillin-tazobactam. Nevertheless, 10 days later the patient had developed recurrent episodes of fever associated with poor general condition. The antibiotic regimen was changed to meropenem, and the patient underwent another debridement, from which a fragment of soft tissue sent for culture yielded growth of colistin-resistant extended-spectrum $\beta$-lactamase (ESBL)-producing E. coli (ICBEC72H) and carbapenem-resistant Citrobacter freundii. Ciprofloxacin was added to the antibiotic regimen at that time, whereas meropenem was stopped after 3 days of combined therapy. The patient underwent lower-limb amputation due to foot necrosis; ciprofloxacin treatment was maintained for 14 days, and the patient was discharged after complete recovery.

The identification and antimicrobial susceptibility testing of the $E$. coli and C. freundii isolates were performed using the Mi-
croScan system (Beckman Coulter). While the E. coli strain presented resistance to ampicillin $(>16 \mu \mathrm{g} / \mathrm{ml})$, ampicillin-sulbac$\operatorname{tam}(>16 / 8 \mu \mathrm{g} / \mathrm{ml})$, aztreonam $(>8 \mu \mathrm{g} / \mathrm{ml})$, cefepime $(>8 \mu \mathrm{g} /$ $\mathrm{ml})$, cefotaxime $(>16 \mu \mathrm{g} / \mathrm{ml})$, cefuroxime $(>16 \mu \mathrm{g} / \mathrm{ml})$, cephalothin $(>16 \mu \mathrm{g} / \mathrm{ml})$, and colistin $(>4 \mu \mathrm{g} / \mathrm{ml})$, the $C$. freundii isolate showed resistance to aztreonam $(>8 \mu \mathrm{g} / \mathrm{ml})$, cefepime $(>8$ $\mu \mathrm{g} / \mathrm{ml})$, cefotaxime $(>16 \mu \mathrm{g} / \mathrm{ml})$, ceftazidime $(8 \mu \mathrm{g} / \mathrm{ml})$, ertapenem $(>1 \mu \mathrm{g} / \mathrm{ml})$, imipenem $(4 \mu \mathrm{g} / \mathrm{ml})$, meropenem $(4 \mu \mathrm{g} / \mathrm{ml})$, piperacillin-tazobactam $(>64 \mu \mathrm{g} / \mathrm{ml})$, tobramycin $(8 \mu \mathrm{g} / \mathrm{ml})$, and trimethoprim-sulfamethoxazole $(>2 / 38 \mu \mathrm{g} / \mathrm{ml})(5,6)$. Both isolates remained susceptible to amikacin, ciprofloxacin, gentamicin, levofloxacin, and tigecycline. The presence of the $b l a_{\mathrm{KPC}-2}$ gene in C. freundii was confirmed by PCR (7), whereas the total genomic DNA of E. coli ICBEC72H was used to construct a mate-paired library, which was sequenced using the MiSeq platform (Illumina, Inc.). Genome assembly was carried out using SPAdes v3.7.1 with the high-quality mate-pair option (8) and, after automatic annotation using Prokka (www.github.com/tseemann/prokka), the sequence was manually curated using the GenBank database and InterPro (www.ebi.ac.uk/interpro). Resistance genes were detected by BLASTn using the ResFinder 2.1 database (https://cge .cbs.dtu.dk/services/ResFinder), plasmid classification was carried out in silico by BLASTn using the PlasmidFinder 1.3 database (https://cge.cbs.dtu.dk/services/PlasmidFinder), and virulence

Received 21 June 2016 Returned for modification 13 July 2016

Accepted 19 July 2016

Accepted manuscript posted online 8 August 2016

Citation Fernandes MR, McCulloch JA, Vianello MA, Moura Q, Pérez-Chaparro PJ,

Esposito F, Sartori L, Dropa M, Matté MH, Lira DPA, Mamizuka EM, Lincopan N.

2016. First report of the globally disseminated IncX4 plasmid carrying the $m c r-1$

gene in a colistin-resistant Escherichia coli sequence type 101 isolate from a

human infection in Brazil. Antimicrob Agents Chemother 60:6415-6417.

doi:10.1128/AAC.01325-16.

Address correspondence to Miriam R. Fernandes, miriamrfernandes@usp.br, or

Nilton Lincopan, lincopan@usp.br.

Copyright $\odot$ 2016, American Society for Microbiology. All Rights Reserved. 


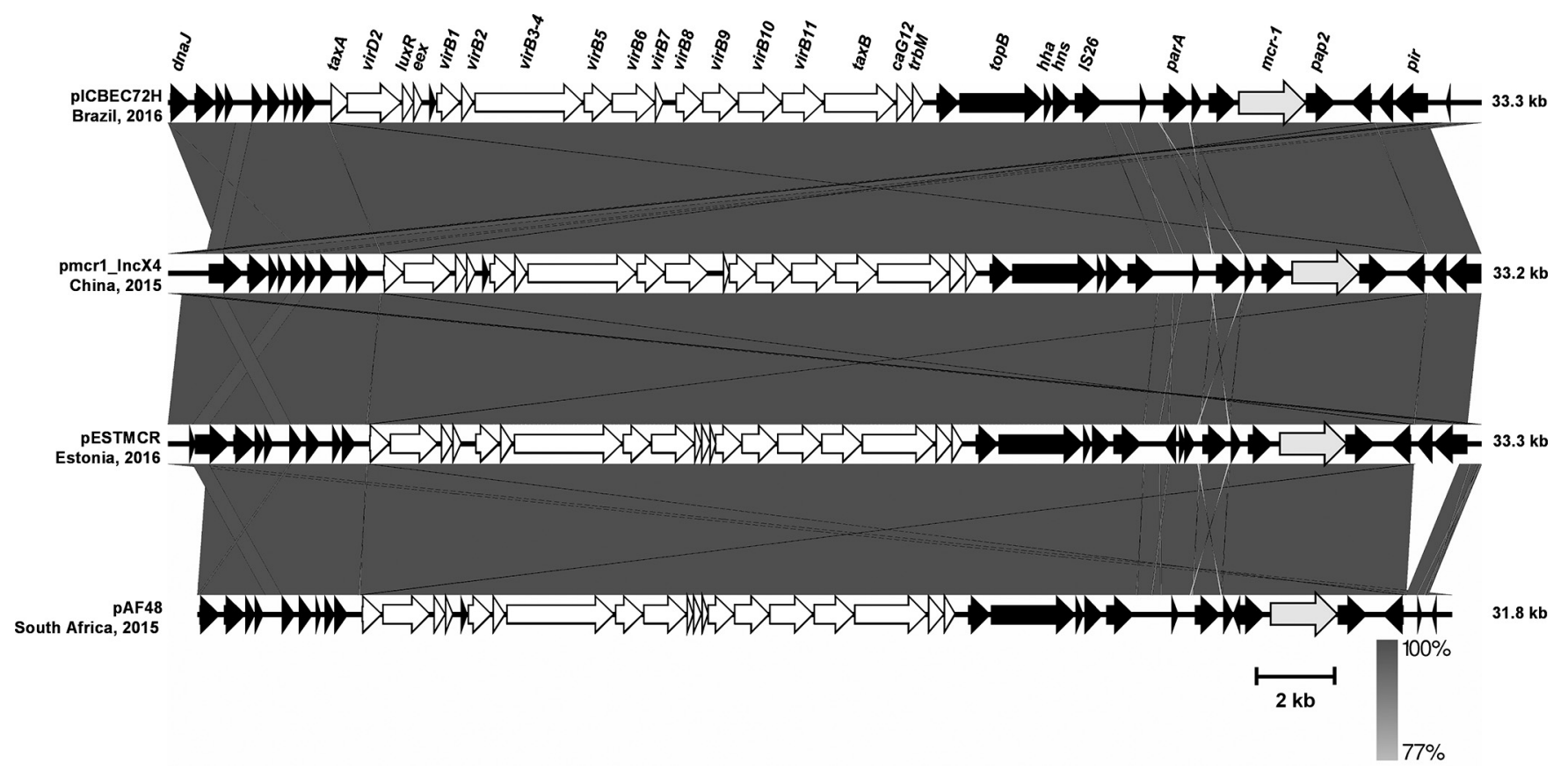

FIG 1 Backbone of pICBEC72Hmcr IncX4 plasmid (GenBank accession no. CP015977) carrying the mcr-1 gene in a human E. coli strain isolated in Brazil. The pICBEC72H plasmid was compared with plasmid pmcr1_IncX4 (GenBank accession no. KU761327.1) from a MCR-1-positive ST25 Klebsiella pneumoniae strain isolated from a human clinical sample in China (12), pESTMCR (GenBank accession no. KU743383.1) from a MCR-1-positive E. coli strain isolated from pig slurry in Estonia, and pAF48 (GenBank accession no. KX032520.1) from a MCR-1-positive ST624 E. coli strain isolated from a human clinical sample in South Africa (13). Comparative analysis was performed using Easyfig version 2.2.2 for genome comparisons. White arrows, genes that are part of transfer modules.

genes were detected by BLASTn using the VirulenceFinder 1.5 database (https://cge.cbs.dtu.dk/services/VirulenceFinder).

Whole-genome sequencing revealed that E. coli ICBEC72H belonged to the widespread sequence type (ST) 101, which was found previously in Australia, Asia, Europe, and North America, where it was found to harbor $b l_{\mathrm{NDM}-1}$ and, less commonly, $b l a_{\mathrm{CTX}-\mathrm{M}}(9-11)$. The presence of the iroN (siderophore), $\mathrm{mcmA}$ (microcin), $m c h B$ (microcin), $m c h C$ (microcin), $m c h F$ (microcin), lpfA (fimbriae), and iss (increased serum survival) virulence genes found in ICBEC72H can be associated with the low-virulence B1 phylogenetic group. Further pulsed-field gel electrophoresis (PFGE) characterization, using XbaI restriction, showed that E. coli ICBEC72H was clonally unrelated to previously identified mcr-1-positive E. coli strains isolated from Brazilian livestock (3).

E. coli ICBEC72H carried the $b l a_{\mathrm{CTX}-\mathrm{M}-8}$ and $m c r-1$ genes on two different plasmids, which were successfully transferred to $E$. coli strain EC600 by conjugation (broth mating method). Transconjugants were selected on MacConkey agar plates containing streptomycin $(200 \mu \mathrm{g} / \mathrm{ml})$ and colistin $(2 \mu \mathrm{g} / \mathrm{ml})$. Conjugative transfer of the plasmid mediating colistin resistance from $E$. coli strain ICBEC72H to recipient E. coli strain EC600 was accompanied by cotransfer of the compatible plasmid conferring thirdgeneration cephalosporin resistance. Plasmid pICBEC72Hctx (92.2 kb in length) was classified as belonging to the IncI1 incompatibility group and carried only $b l a_{\text {СтХ-М-8 }}$, whereas the plasmid carrying $m c r-1$ (pICBEC72Hmcr) was $33.67 \mathrm{~kb}$ in length and belonged to the IncX4 incompatibility group.

Multiple MAFFT alignments between pICBEC72Hmcr and the other three IncX4 plasmids bearing $m c r-1$ that are available in GenBank showed very high levels of architectural conservation among these plasmids, with pICBEC72Hmcr presenting 99.9\% nucleotide identity with pmcr1_IncX4 (GenBank accession no. KU761327.1), which was found in a ST25 Klebsiella pneumoniae strain isolated from a human clinical sample in China (12), and pESTMCR (GenBank accession no. KU743383.1), which was found in an E. coli strain isolated from pig slurry in Estonia. Plasmid pICBEC72Hmcr presented $96.3 \%$ identity with pAF48 (GenBank accession no. KX032520.1), which was found in an $E$. coli strain isolated from a human clinical sample in South Africa (13), because the latter plasmid presents an $\sim 1,200$-bp deletion that includes a partial deletion of the replication initiation protein PI and a few indels, mostly in noncoding sequences (Fig. 1). The insertion sequence ISApll, which was initially found to be associated with $m c r-1$ in pHNSHP45 (1), was not present in the IncX4 plasmid (Fig. 1) (12, 13).

IncX plasmids are self-transmissible plasmids that include at least five subtypes (IncX1 to IncX5) and previously were thought to be of low prevalence $(14,15)$. Instead, IncX plasmids have been implicated in the spread of many resistance genes, including ESBL- and carbapenemase-encoding genes (15-18). Recently, IncX4 plasmids carrying the $\mathrm{mcr}-1$ gene were identified in Salmonella enterica (serovars Typhimurium, Parathyphi B, Java, Anatum, and Schwartzengrund) from human infections, ready-tocook guinea fowl pie, and poultry meat in England, France, and Netherlands (19-21), respectively, and in E. coli isolated from imported chicken meat in Denmark (22), swine in Germany (23), livestock in the Netherlands (21), and human samples in China (12) and South Africa (13). What is surprising is the fact that the mcr-1-bearing IncX4 plasmids obtained from different bacterial species, belonging to different STs, isolated in different clinical contexts, and found on different continents are highly similar in the plasmid backbone sequences. This strongly suggests that self- 
transmissible IncX4-type plasmids may represent promiscuous plasmids contributing to the intercontinental spread of the $\mathrm{mcr}-1$ gene.

Accession number(s). Sequences have been deposited in GenBank, and the accession numbers can be found via BioSample record number PRJNA322664.

\section{ACKNOWLEDGMENTS}

FAPESP and CNPq research grants are gratefully acknowledged. N.L. and J.A.M. are research grant fellows of CNPq and FAPESP, respectively.

We thank Cefar Diagnóstica Ltda. (Brazil) for kindly supplying antibiotic discs for susceptibility testing.

\section{FUNDING INFORMATION}

This work was funded by research grant 2013/12107-4 from Fundação de Amparo à Pesquisa do Estado de São Paulo (FAPESP) and Conselho Nacional de Desenvolvimento Científico e Tecnológico (CNPq) grants 485438/2012-7 and 457421/2014-2.

\section{REFERENCES}

1. Liu YY, Wang Y, Walsh TR, Yi LX, Zhang R, Spencer J, Doi Y, Tian G, Dong B, Huang X, Yu LF, Gu D, Ren H, Chen X, Lv L, He D, Zhou H, Liang Z, Liu JH, Shen J. 2016. Emergence of plasmid-mediated colistin resistance mechanism MCR-1 in animals and human beings in China: a microbiological and molecular biological study. Lancet Infect Dis 16:161168. http://dx.doi.org/10.1016/S1473-3099(15)00424-7.

2. Skov RL, Monnet DL. 2016. Plasmid-mediated colistin resistance ( $\mathrm{mcr}-1$ gene): three months later, the story unfolds. Euro Surveill 21(9): pii=30155. http://dx.doi.org/10.2807/1560-7917.ES.2016.21.9.30155.

3. Fernandes MR, Moura Q, Sartori L, Silva KC, Cunha MP, Esposito F, Lopes R, Otutumi LK, Gonçalves DD, Dropa M, Matté MH, Monte DF, Landgraf M, Francisco GR, Bueno MF, de Oliveira Garcia D, Knöbl T, Moreno AM, Lincopan N. 2016. Silent dissemination of colistin-resistant Escherichia coli in South America could contribute to the global spread of the $m c r-1$ gene. Euro Surveill 21(17):pii=30214. http://dx.doi.org/10 .2807/1560-7917.ES.2016.21.17.30214.

4. Rapoport M, Faccone D, Pasteran F, Ceriana P, Albornoz E, Petroni A, MCR Group, Corso A. 2016. mcr-1-mediated colistin resistance in human infections caused by Escherichia coli: first description in Latin America. Antimicrob Agents Chemother http://dx.doi.org/10.1128/AAC .00573-16.

5. European Committee on Antimicrobial Susceptibility Testing. 2016. Breakpoint tables for interpretation of MICs and zone diameters, v. 6. http:// www.eucast.org/fileadmin/src/media/PDFs/EUCAST_files/Breakpoint _tables/v_6.0_Breakpoint_table.pdf.

6. Clinical and Laboratory Standards Institute. 2014. Performance standards for antimicrobial susceptibility testing; 24th informational supplement. CLSI document M100-S24. Clinical and Laboratory Standards Institute, Wayne, PA.

7. Nordmann P, Naas T, Poirel L. 2011. Global spread of carbapenemaseproducing Enterobacteriaceae. Emerg Infect Dis 17:1791-1798. http://dx .doi.org/10.3201/eid1710.110655.

8. Vasilinetc I, Prjibelski AD, Gurevich A, Korobeynikov A, Pevzner PA. 2015. Assembling short reads from jumping libraries with large insert sizes. Bioinformatics 31:3262-3268. http://dx.doi.org/10.1093 /bioinformatics/btv337.

9. Yoo JS, Kim HM, Koo HS, Yang JW, Yoo JI, Kim HS, Park HK, Lee YS. 2013. Nosocomial transmission of NDM-1-producing Escherichia coli ST101 in a Korean hospital. J Antimicrob Chemother 68:2170-2172. http: //dx.doi.org/10.1093/jac/dkt126.

10. Mushtaq S, Irfan S, Sarma JB, Doumith M, Pike R, Pitout J, Livermore DM, Woodford N. 2011. Phylogenetic diversity of Escherichia coli strains producing NDM-type carbapenemases. J Antimicrob Chemother 66: 2002-2005. http://dx.doi.org/10.1093/jac/dkr226.
11. Mora A, Blanco M, López C, Mamani R, Blanco JE, Alonso MP, García-Garrote F, Dahbi G, Herrera A, Fernández A, Fernández B, Agulla A, Bou G, Blanco J. 2011. Emergence of clonal groups O1:HNMD-ST59, O15:H1-D-ST393, O20:H34/HNM-D-ST354, O25b:H4-B2ST131 and ONT:H21,42-B1-ST101 among CTX-M-14-producing Escherichia coli clinical isolates in Galicia, northwest Spain. Int J Antimicrob Agents 37:16-21. http://dx.doi.org/10.1016/j.ijantimicag.2010.09.012.

12. Li A, Yang Y, Miao M, Chavda KD, Mediavilla JR, Xie X, Feng P, Tang YW, Kreiswirth BN, Chen L, Du H. 2016. Complete sequences of mcr1 -harboring plasmids from extended spectrum $\beta$-lactamase- and carbapenemase-producing Enterobacteriaceae. Antimicrob Agents Chemother 60:4351-4354. http://dx.doi.org/10.1128/AAC.00550-16.

13. Poirel L, Kieffer N, Brink A, Coetze J, Jayol A, Nordmann P. 2016. Genetic features of MCR-1-producing colistin-resistant Escherichia coli isolates, South Africa. Antimicrob Agents Chemother http://dx.doi.org/10 .1128/AAC.00444-16.

14. Johnson TJ, Bielak EM, Fortini D, Hansen LH, Hasman H, Debroy C, Nolan LK, Carattoli A. 2012. Expansion of the IncX plasmid family for improved identification and typing of novel plasmids in drugresistant Enterobacteriaceae. Plasmid 68:43-50. http://dx.doi.org/10.1016 /j.plasmid.2012.03.001.

15. Lo WU, Chow KH, Law PY, Ng KY, Cheung YY, Lai EL, Ho PL. 2014. Highly conjugative IncX4 plasmids carrying bla $_{\text {СТХ-M }}$ in Escherichia coli from humans and food animals. J Med Microbiol 63:835-840. http://dx doi.org/10.1099/jmm.0.074021-0.

16. Stokes MO, Abuoun M, Umur S, Wu G, Partridge SR, Mevius DJ, Coldham NG, Fielder MD. 2013. Complete sequence of pSAM7, an IncX4 plasmid carrying a novel $b l a_{\mathrm{CTX}-\mathrm{M}-14 \mathrm{~b}}$ transposition unit isolated from Escherichia coli and Enterobacter cloacae from cattle. Antimicrob Agents Chemother 57:4590-4594. http://dx.doi.org/10.1128/AAC.01157-13.

17. Ho PL, Cheung YY, Lo WU, Li Z, Chow KH, Lin CH, Chan JF, Cheng VC. 2013. Molecular characterization of an atypical IncX3 plasmid pKPCNY79 carrying $b l a_{\mathrm{KPC}-2}$ in a Klebsiella pneumoniae. Curr Microbiol 67: 493-498. http://dx.doi.org/10.1007/s00284-013-0398-2.

18. Chen L, Chavda KD, Fraimow HS, Mediavilla JR, Melano RG, Jacobs MR, Bonomo RA, Kreiswirth BN. 2013. Complete nucleotide sequences of $b l a_{\mathrm{KPC}-4^{-}}$and $b l a_{\mathrm{KPC}-5^{-}}$-harboring IncN and IncX plasmids from Klebsiella pneumoniae strains isolated in New Jersey. Antimicrob Agents Chemother 57:269-276. http://dx.doi.org/10.1128/AAC.01648-12.

19. Doumith M, Godbole G, Ashton P, Larkin L, Dallman T, Day M, Day M, Muller-Pebody B, Ellington MJ, de Pinna E, Johnson AP, Hopkins KL, Woodford N. 2016. Detection of the plasmid-mediated $\mathrm{mcr}-1$ gene conferring colistin resistance in human and food isolates of Salmonella enterica and Escherichia coli in England and Wales. J Antimicrob Chemother 71:2300-2305. http://dx.doi.org/10.1093/jac/dkw093.

20. Webb HE, Granier SA, Marault M, Millemann Y, den Bakker HC, Nightingale KK, Bugarel M, Ison SA, Scott HM, Loneragan GH. 2016. Dissemination of the $m c r-1$ colistin resistance gene. Lancet Infect Dis 16: 144-145. http://dx.doi.org/10.1016/S1473-3099(15)00538-1.

21. Veldman K, van Essen-Zandbergen A, Rapallini M, Wit B, Heymans R, van Pelt W, Mevius D. 2016. Location of colistin resistance gene $m c r-1$ in Enterobacteriaceae from livestock and meat. J Antimicrob Chemother http://dx.doi.org/10.1093/jac/dkw181.

22. Hasman H, Hammerum AM, Hansen F, Hendriksen RS, Olesen B, Agersø Y, Zankari E, Leekitcharoenphon P, Stegger M, Kaas RS, Cavaco LM, Hansen DS, Aarestrup FM, Skov RL. 2015. Detection of $m c r-1$ encoding plasmid-mediated colistin-resistant Escherichia coli isolates from human bloodstream infection and imported chicken meat, Denmark 2015. Euro Surveill 20(49):pii=30085. http://dx.doi.org/10.2807 /1560-7917.ES.2015.20.49.30085.

23. Falgenhauer L, Waezsada SE, Yao Y, Imirzalioglu C, Käsbohrer A, Roesler U, Michael GB, Schwarz S, Werner G, Kreienbrock L, Chakraborty T. 2016. Colistin resistance gene $m c r-1$ in extendedspectrum $\beta$-lactamase-producing and carbapenemase-producing Gramnegative bacteria in Germany. Lancet Infect Dis 16:282-283. http://dx.doi .org/10.1016/S1473-3099(16)00009-8. 


\section{Journal of Antimicrobial Chemotherapy Advance Access published December 28, 2016

J Antimicrob Chemother

doi:10.1093/jac/dkw543

\section{Escherichia coli carrying IncX4 plasmid-mediated mcr-1 and bla CTX-M $_{\text {. }}$ genes in infected migratory Magellanic penguins (Spheniscus magellanicus)}

\author{
Fábio P. Sellera ${ }^{1}$, Miriam R. Fernandes ${ }^{2}$, \\ Luciana Sartori ${ }^{2}$, Marcelo P. N. Carvalho ${ }^{3}$, \\ Fernanda Esposito ${ }^{2}$, Cristiane L. Nascimento ${ }^{4}$, \\ Gustavo H. P. Dutra ${ }^{4}$, Elsa M. Mamizuka², \\ Paula J. Pérez-Chaparro ${ }^{2}$, John A. McCulloch ${ }^{2}$ \\ and Nilton Lincopan ${ }^{2,5 *}$
}

\begin{abstract}
${ }^{1}$ Department of Internal Medicine, School of Veterinary Medicine and Animal Science, University of São Paulo, São Paulo, Brazil; ${ }^{2}$ Department of Clinical Analysis, Faculty of Pharmaceutical Sciences, University of São Paulo, São Paulo, Brazil; ${ }^{3}$ Department of Pathology, School of Veterinary Medicine and Animal Science, University of São Paulo, São Paulo, Brazil; ${ }^{4}$ Veterinary Unit of Santos Aquarium, Santos, Brazil; ${ }^{5}$ Department of Microbiology, Institute of Biomedical Sciences, University of São Paulo, São Paulo, Brazil
\end{abstract}

*Corresponding author. Tel: +55-11-3091-7296; Fax: +55-11-3091-7354; E-mail: lincopan@usp.br

Sir,

The emergence and rapid dissemination of Gram-negative pathogens carrying the plasmid-mediated colistin resistance $\mathrm{mcr}-1$ gene have become a global threat to public health. ${ }^{1}$ It is worrisome that the reservoirs for such organisms are increasing, not only in livestock, but also in wild animals and the environment. ${ }^{2-4}$ In this regard, two recent reports published in JAC have described the presence of mcr-1-positive Escherichia coli in faecal samples of healthy wild birds (i.e. European herring gulls and kelp gulls). ${ }^{3,4}$ In this study, we report for the first known time the occurrence of

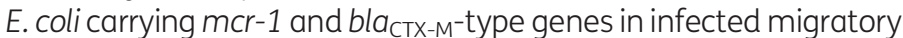
Magellanic penguins (Spheniscus magellanicus) suffering from bumblefoot (pododermatitis), highlighting a possible source of transmission of these organisms.

Magellanic penguins are seabirds that live exclusively in the Southern Hemisphere (Argentina, Chile and Falkland/Malvinas Islands). ${ }^{5}$ Brazil is on the migration route of this species and every year a large number of these birds arrive on beaches of the south and southeast coast, ${ }^{5}$ where animals are kept in rehabilitation centres. Between 2006 and 2014, 261 penguins were admitted to a rehabilitation centre on the southeast coast of Brazil $\left(23^{\circ} 59^{\prime} 10.7^{\prime \prime} \mathrm{S}, 46^{\circ} 18^{\prime} 30.1^{\prime \prime} \mathrm{W}\right)$. About $70 \%$ did not survive due to malnutrition and weakness developed during the migration period. In 2013, 24 animals succumbed to pododermatitis, which was associated with underlying infection of the footpad. ${ }^{6}$ Samples collected from infected footpads of 13 animals were positive for E. coli.

As part of an antimicrobial resistance surveillance study, we have investigated these E. coli strains for transferable colistin resistance and production of ESBL, ${ }^{7}$ leading to the identification of three ESBL-producing E. coli strains (ICBEC7P, ICBEC11P and ICBEC12P), which exhibited an MDR profile to ampicillin, ceftiofur, ceftazidime $(\geq 8 \mathrm{mg} / \mathrm{L})$, cefotaxime $(>32 \mathrm{mg} / \mathrm{L})$, cefepime, aztreonam, amikacin, gentamicin ( $\geq 32 \mathrm{mg} / \mathrm{L})$, sulfamethoxazole/ trimethoprim, enrofloxacin, ciprofloxacin ( $>32 \mathrm{mg} / \mathrm{L}$ ) and tetracycline ( $\geq 64 \mathrm{mg} / \mathrm{L}$ ), as determined by disc diffusion or Etest methods. ${ }^{7}$ ESBL production was confirmed by using a double-disc synergy test (DDST), and PCR screening and sequencing revealed bla $a_{\mathrm{CTX}-\mathrm{M}-1}$ in ICBEC7P and ICBEC11P, and bla $a_{\mathrm{CTX}-\mathrm{M}-2}$ in ICBEC12P. Although all isolates remained susceptible to ertapenem $(0.016 \mathrm{mg} / \mathrm{L})$, imipenem, meropenem and cefoxitin $(1 \mathrm{mg} / \mathrm{L})$, the E. coli strain ICBEC7P showed additional resistance to colistin $(8 \mathrm{mg} / \mathrm{L}){ }^{8}$, due to the presence of the $\mathrm{mcr}-1$ gene. ${ }^{1}$

The total genomic DNA of E. coli ICBEC7P was used to construct a paired-end library, which was sequenced using the Miseq platform (Illumina). Genome assembly was carried out using SPAdes v3.9.0 and contigs were annotated using Prokka (www.github. com/tseemann/prokka). The $15.5 \mathrm{kbp}$ contig containing the mcr-1 gene was found to bear an IncX4 replicon signature, as determined by the PlasmidFinder database (https://cge.cbs.dtu.dk/ser vices/PlasmidFinder/). Another $17.5 \mathrm{kbp}$ contig was found to host a hit showing $>99 \%$ identity to another IncX 4 plasmid harbouring mcr-1, which we had sequenced using mate-pair reads (GenBank accession number CP015977). These two contigs were then concatenated with a gap, and the gap was closed and the plasmid circularized using the paired-end reads for ICBEC7P with GapFiller (www.baseclear.com/genomics/bioinformatics/basetools/ gapfiller). The complete circularized sequence of pICBEC7Pmcr was deposited in GenBank under accession number CP017246. Serotype, MLST ST, plasmid replicons, antimicrobial resistance genes and virulence genes for E. coli ICBEC7P were identified using the SerotypeFinder 1.1, MLST 1.8, PlasmidFinder 1.3, ResFinder 2.1 and VirulenceFinder 1.5 databases, respectively, available from the Center for Genomic Epidemiology (http://genomi cepidemiology.org/).

The WGS analysis showed that E. coli ICBEC7P belonged to serotype ONT:H32 and MLST ST10. ST10 has been globally reported from livestock, food, human and environmental samples, being associated with the production of CTX-M-type ESBLs and, more recently, the MCR-1 enzyme, supporting a great versatility for adaptation to different hosts. ${ }^{9,10}$ On the other hand, presence of the gad (glutamate decarboxylase) gene found in ICBEC7P can be associated with the low-virulence phylogenetic group A. E. coli ICBEC7P harboured IncFIB, IncN, IncHI2, IncHI2A, IncI1 and IncX4 plasmids. The plasmid bearing the bla $a_{\mathrm{CTX}-\mathrm{M}-1}$ gene (pICBEC7Pctx) was successfully transferred to the E. coli $\mathrm{C} 600$ strain by the broth mating method, and belonged to the IncFIB incompatibility group according to PCR-based

(c) The Author 2016. Published by Oxford University Press on behalf of the British Society for Antimicrobial Chemotherapy. All rights reserved. ForPermissions, please email: journals.permissions@oup.com. 
replicon typing. ${ }^{11}$ Transconjugants were selected on MacConkey agar plates containing streptomycin $(200 \mathrm{mg} / \mathrm{L})$ and ceftriaxone (2 mg/L). The 33.3 kb IncX4 plasmid carrying mcr-1 (pICBEC7Pmcr) displayed $95.2 \%$ nucleotide identity to a plasmid originating from a human patient in Brazil (pICBEC72Hmcr, GenBank accession number CP015977). ${ }^{12}$ The only difference between the two plasmids was the truncation of mobA due to the insertion of IS1294 in pICBEC7Pmcr. This mutation may explain why the attempts to mobilize $\mathrm{mcr}-1$ from E. coli ICBEC7P by in vitro conjugation were unsuccessful. Non-conjugative plasmids are common in members of the Enterobacteriaceae family, and probably rely largely on vertical transmission to be maintained in bacterial populations, ${ }^{13}$ where they contribute to the persistence of resistance genes among clonal lineages.

The complete sequence of pICBEC7Pmcr reinforces the ubiquity of this IncX4 plasmid, which carries $\mathrm{mcr}-1$, and sheds light on the role of this incompatibility group in the global spread of colistin resistance, ${ }^{12,14}$ even to wildlife. On the other hand, since E. coli is a potential zoonotic pathogen, a meticulous microbiological and epidemiological investigation of strains of this sort must be performed, in order to identify reservoirs and potential transmission routes.

\section{Acknowledgements}

FAPESP (process number 2016/08593-9) and CNPq research grants are gratefully acknowledged. N. L. is a research grant fellow of CNPq. J. A. M. is supported by FAPESP grant number 2013/12107-4. We thank Cefar Diagnóstica Ltda (Brazil) for kindly supplying antibiotic discs for susceptibility testing.

\section{Funding}

This work was funded by research grants from Fundação de Amparo à Pesquisa do Estado de São Paulo (FAPESP) and Conselho Nacional de Desenvolvimento Científico e Tecnológico (CNPq).

\section{Transparency declarations}

None to declare.

\section{References}

1 Liu YY, Wang Y, Walsh TR et al. Emergence of plasmid-mediated colistin resistance mechanism MCR-1 in animals and human beings in China: a microbiological and molecular biological study. Lancet Infect Dis 2016; 16: 161-8.

2 Schwarz S, Johnson AP. Transferable resistance to colistin: a new but old threat. J Antimicrob Chemother 2016; 71: 2066-70.

3 Ruzauskas M, Vaskeviciute L. Detection of the mcr-1 gene in Escherichia coli prevalent in the migratory bird species Larus argentatus. J Antimicrob Chemother 2016; 71: 2333-4.

4 Liakopoulos A, Mevius DJ, Olsen B et al. The colistin resistance mcr-1 gene is going wild. J Antimicrob Chemother 2016; 71: 2335-6.

5 Stokes DL, Boersma PD, Lopez de Casenave J et al. Conservation of migratory Magellanic penguins requires marine zoning. Biol Conserv 2014; 170 151-61.

6 Sellera FP, Sabino CP, Ribeiro MS et al. Photodynamic therapy for pododermatitis in penguins. Zoo Biol 2014; 33: 353-6.

7 Clinical and Laboratory Standards Institute. Performance Standards for Antimicrobial Susceptibility Testing: Twenty-fourth Informational Supplement M100-S24. CLSI, Wayne, PA, USA, 2014.

8 EUCAST. Breakpoint Tables for Interpretation of MICs and Zone Diameters, Version 6. 2016. http://www.eucast.org/fileadmin/src/media/PDFs/EUCAST_ files/Breakpoint_tables/v_6.0_Breakpoint_table.pdf.

9 Day MJ, Rodríguez I, van Essen-Zandbergen A et al. Diversity of STs, plasmids and ESBL genes among Escherichia coli from humans, animals and food in Germany, the Netherlands and the UK. J Antimicrob Chemother 2016; 71: 1178-82.

10 El Garch F, Sauget M, Hocquet D et al. mcr-1 is borne by highly diverse Escherichia coli isolates since 2004 in food-producing animals in Europe. Clin Microbiol Infect 2016. http://dx.doi.org/10.1016/j.cmi.2016.08.033.

11 Caratolli A, Bertini A, Villa L et al. Identification of plasmids by PCR-based replicon typing. J Microbiol Methods 2005; 63: 219-28.

12 Fernandes MR, McCulloch JA, Vianello MA et al. First report of the globally disseminated IncX4 plasmid carrying the $\mathrm{mcr}-1$ gene in a colistin resistant Escherichia coli ST101 isolated from a human infection in Brazil. Antimicrob Agents Chemother 2016; 60: 6415-7.

13 San Millan A, Peña-Miller R, Toll-Riera M et al. Positive selection and compensatory adaptation interact to stabilize non-transmissible plasmids. Nat Commun 2014; 5: 5208.

14 Di Pilato V, Arena F, Tascini C et al. mcr-1.2, a new mcr variant carried on a transferable plasmid from a colistin-resistant KPC carbapenemaseproducing Klebsiella pneumoniae strain of sequence type 512. Antimicrob Agents Chemother 2016; 60: 5612-5. 


\section{Colistin-Resistant mcr-1-Positive Escherichia coli on Public Beaches, an Infectious Threat Emerging in Recreational Waters}

\author{
Miriam R. Fernandes, ${ }^{a}$ Fábio P. Sellera, ${ }^{\mathrm{b}}$ Fernanda Esposito, ${ }^{\mathrm{a}}$ Caetano P. Sabino, ${ }^{\mathrm{a}}$ \\ Louise Cerdeira, ${ }^{a}$ (D) Nilton Lincopan ${ }^{a, c}$ \\ Department of Clinical Analysis, School of Pharmacy, University of São Paulo, São Paulo, Brazila; Department of \\ Internal Medicine, School of Veterinary Medicine and Animal Science, University of São Paulo, São Paulo, \\ Brazilb; Department of Microbiology, Institute of Biomedical Sciences, University of São Paulo, São Paulo, Brazilc
}

ABSTRACT The emergence and rapid spread of colistin-resistant Escherichia coli carrying the mcr-1 gene have generated an urgent need to strengthen surveillance. We performed a meticulous investigation of strains of this sort, which resulted in the identification of international clones of E. coli carrying IncX4-plasmid-mediated $\mathrm{mcr}-1$ and $b / a_{\text {СTX-M }}$ genes in recreational waters of public urban beaches in cities with high tourist turnover, highlighting a new environmental reservoir.

KEYWORDS MCR-1, ESBL, CTX-M, IncX4, polymyxins, Brazil

T he emergence and rapid spread of colistin-resistant Enterobacteriaceae carrying the mcr-1 gene have generated a profound sense of public alarm (1). Escherichia coli, one of the bacterial species that is most widely distributed and exchanged between the environment, animals, and humans, has been the main host of $\operatorname{mcr}-1(2,3)$. In South America, the occurrence of $E$. coli carrying $m c r-1$ and bla $a_{\text {CTX-M }}$ genes in human (4-6) and wild animal (7) infections and food-producing animals (8) has created an urgent need to strengthen epidemiological surveillance. Using a whole-genome sequencing (WGS) approach, we performed a meticulous investigation of strains of this sort, which resulted in the identification of international clones of $E$. coli carrying $\mathrm{mcr}_{-1}$ and bla $a_{\text {СTX-M- }}$ type genes in recreational waters of public urban beaches and highlighted a new source of transmission of this infectious threat.

In September 2016, coastal water samples were collected from 11 different public beaches (in the southeastern Brazilian continental margin of São Paulo State) surrounding urban counties with a population of about 800,000 inhabitants, which can double during the summer. Following standard methods for the examination of water and wastewater (http://www.standardmethods.org), 500-ml surface water samples were collected, on the same day, in sterile bottles, transported to the laboratory in cooled containers (at about $4^{\circ} \mathrm{C}$ to $10^{\circ} \mathrm{C}$ ), and processed within $6 \mathrm{~h}$. From each water sample, $100 \mathrm{ml}$ was concentrated by filtration through sterile membrane filters with a pore size of $0.45 \mu \mathrm{m}$. The filters were placed on MacConkey agar plates and incubated for $24 \mathrm{~h}$ at $37^{\circ} \mathrm{C}$. Next, the membrane filters were aseptically removed and placed separately in sterile tubes that had been filled previously with $10 \mathrm{ml}$ of sterile Mueller-Hinton broth. After vortex mixing, an aliquot $(100 \mu \mathrm{l})$ of each culture was streaked on MacConkey agar plates supplemented with colistin $(2 \mu \mathrm{g} / \mathrm{ml})$.

Three colistin-resistant $E$. coli strains were recovered from different beaches located in the cities of São Vicente and Santos (Fig. 1); the latter is the major beachfront city of the region, with the largest shipping terminal in Latin America. The isolates were identified by matrix-assisted laser desorption ionization-time of flight mass spectrom-
Received 2 February 2017 Returned for modification 14 March 2017 Accepted 2 March 2017

Accepted manuscript posted online 17 April 2017

Citation Fernandes MR, Sellera FP, Esposito F, Sabino CP, Cerdeira L, Lincopan N. 2017. Colistin-resistant mcr-1-positive Escherichia coli on public beaches, an infectious threat emerging in recreational waters. Antimicrob Agents Chemother 61:e00234-17. https://doi .org/10.1128/AAC.00234-17.

Copyright $\odot 2017$ American Society for Microbiology. All Rights Reserved.

Address correspondence to Miriam R. Fernandes, miriamrfernandes@usp.br, or Nilton Lincopan, lincopan@usp.br. 


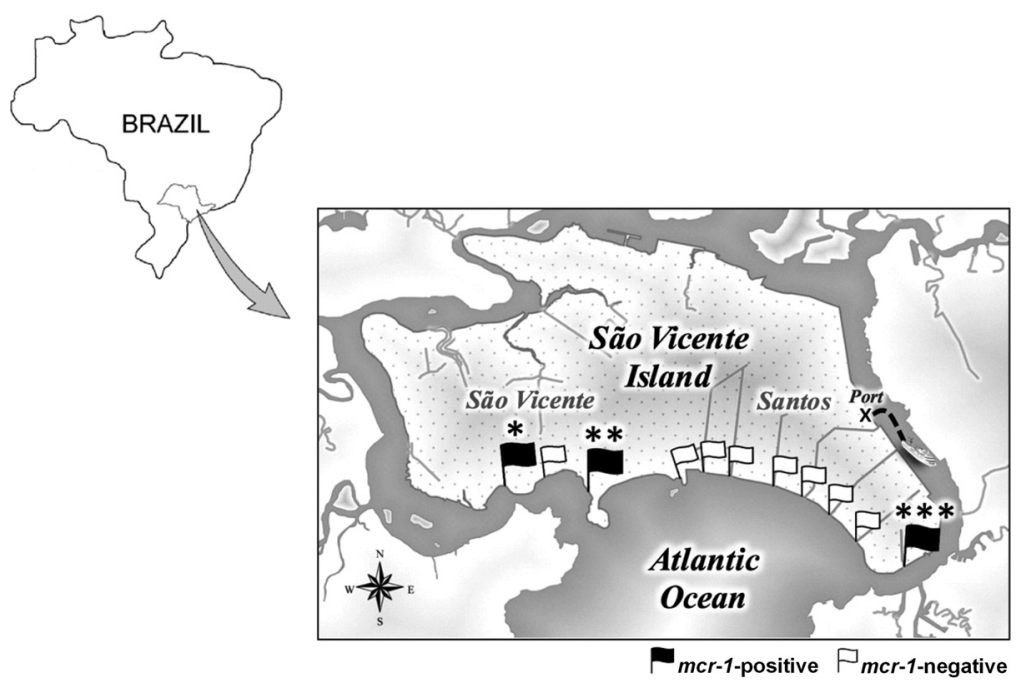

FIG 1 Map showing sampling locations (represented by flags) on public beaches surrounding the area of Santos and São Vicente cities, in the southeastern Brazilian continental margin of São Paulo State. MCR-1-positive E. coli strains (black flags) were isolated from seawater at recreational beaches in São Vicente (*, ICBEC2AM [location, -23.974697S, -46.395060W]; **, ICBEC3AM [location, -23.974995S, $-46.371613 \mathrm{~W}])$ and Santos (***, ICBEC13AM [location, $-23.986450 \mathrm{~S},-46.309086 \mathrm{~W}])$.

etry (MALDI-TOF MS) analysis, and antimicrobial susceptibility profiles and polymyxin MICs were determined by using the disc diffusion and broth microdilution methods, respectively $(9,10)$. Additionally, imipenem and meropenem MICs were determined by using the Etest method, and all isolates displayed susceptibility to imipenem (MICs of $\leq 0.19 \mu \mathrm{g} / \mathrm{ml}$ ) and meropenem (MICs of $\leq 0.032 \mu \mathrm{g} / \mathrm{ml}$ ).

DNA libraries from ICBEC2AM and ICBEC3AM E. coli isolates were sequenced using the NextSeq platform with paired-end reads (Illumina), whereas the DNA library from ICBEC13AM E. coli was sequenced using the MiSeq platform with paired-end reads (Illumina). Serotypes (STs), multilocus sequence typing (MLST), plasmid replicons, antimicrobial resistance genes, and $E$. coli virulence genes were identified or performed using multiple databases, i.e., SerotypeFinder 1.1, MLST 1.8, PlasmidFinder 1.3, ResFinder 2.1, and VirulenceFinder 1.5, respectively, available from the Center for Genomic Epidemiology.

The presence of $m c r-1$ and other clinically important resistance genes, including the extended-spectrum $\beta$-lactamase (ESBL) genes bla $a_{\mathrm{CTX}-8}$ and bla $a_{\mathrm{CTX}-\mathrm{M}-1}$, conferred a multidrug resistance (MDR) phenotype to $E$. coli strains belonging to the globally reported sequence types ST10, ST46, and ST1638 (Table 1). ST10 and ST46 encompass pathogenic strains responsible for human and animal infections, as reported for $E$. coli $(7,11$, 12). Interestingly, the isolation of an E. coli ST10 strain carrying the $\mathrm{mcr}-1$ gene from a water sample collected from a public beach on the coast of Santos city and the isolation of an E. coli ST10 strain from an infected migratory Magellanic penguin suffering from pododermatitis, in the same area, in an earlier study by our group (7) suggest that the ubiquitous ST10 survives easily and also spreads in the marine environment. Indeed, all E. coli stains identified in this study showed tolerance to $\mathrm{NaCl}$ concentrations up to $10 \%$ (Table 1). Recent studies have reported observation of the coexistence of $\mathrm{mcr}^{-1}$ and $b / a_{\text {СTX-M }}$ in MDR E. coli strains belonging to the ST10 complex in well water in rural China (13), identification of environmental $\mathrm{mcr}$-1-positive $E$. coli isolates surrounding German swine farm areas (14), and isolation of $m c r-1$-positive E. coli strains from diseased food-producing animals in China (15) and in France and Italy (16), supporting the rapid adaptation of these lineages to different hosts and ecosystems.

IncX4 plasmids ( $\sim 33 \mathrm{~kb}$ ) were identified by WGS analysis in all strains carrying the mcr-1 gene. After de novo assembly, plasmid sequences were manually annotated using Geneious R9 software, and then PlasmidFinder 1.3 was used to identify incompatibility 
TABLE 1 Characteristics of colistin-resistant Escherichia coli strains carrying the $\mathrm{mcr}-1$ gene from Brazil

\begin{tabular}{|c|c|c|c|c|c|}
\hline Characteristic $^{a}$ & ICBEC2AM & ICBECЗAM & ICBEC13AM & ICBEC7P & ICBEC72H \\
\hline Source & Seawater & Seawater & Seawater & $\begin{array}{l}\text { Infected migratory } \\
\text { penguin }\end{array}$ & Human infection \\
\hline Location & $\begin{array}{l}-23.974697 \mathrm{~S} \\
-46.395060 \mathrm{~W}\end{array}$ & $\begin{array}{l}-23.974995 \mathrm{~S} \\
-46.371613 \mathrm{~W}\end{array}$ & $\begin{array}{l}-23.986450 \mathrm{~S} \\
-46.309086 \mathrm{~W}\end{array}$ & $\begin{array}{l}-23.986306 \mathrm{~S} \\
-46.308361 \mathrm{~W}\end{array}$ & $\begin{array}{l}-5.779257 \mathrm{~S} \\
-35.200916 \mathrm{~W}\end{array}$ \\
\hline Isolation date & September 2016 & September 2016 & September 2016 & June 2013 & March 2016 \\
\hline $\mathrm{NaCl}$ tolerance $(\%)$ & 10 & 10 & 10 & 10 & 10 \\
\hline Serotype & ONT:H55 & O9:H4 & O54:H32 & ONT:H32 & ONT:H9 \\
\hline $\mathrm{ST} / \mathrm{CC}$ & 1638 & $46 / 46$ & $10 / 10$ & $10 / 10$ & $101 / 43$ \\
\hline Virulence genes & Not detected & iss, gad, mchF & gad & gad & $\begin{array}{l}\operatorname{iroN}, \text { mcmA, mchB, mchC, } \\
\text { mchF, IpfA, iss }\end{array}$ \\
\hline Phylogroup & B1 & B1 & B1 & $A$ & B1 \\
\hline Resistance & $\begin{array}{l}\text { AMO, AMP, CAZ, CEF, } \\
\text { CRO, CTF, CTX, } \\
\text { DOX, NAL, SUL, } \\
\text { TET }\end{array}$ & $\begin{array}{l}\text { AMO, CEF, CLO, NAL, } \\
\text { SUL, SXT }\end{array}$ & $\begin{array}{l}\text { AMO, AMP, ATM, CAZ, } \\
\text { CEF, CRO, CTX, } \\
\text { DOX, NAL, SUL, } \\
\text { SXT, TET }\end{array}$ & $\begin{array}{l}\text { AMK, AMO, AMP, ATM, } \\
\text { CAZ, CEF, CIP, CTF, } \\
\text { CTX, ENR, FEP, GEN, } \\
\text { NAL, SXT, TET }\end{array}$ & $\begin{array}{l}\text { AMO, AMP, ATM, CEF, } \\
\text { CTX, FEP }\end{array}$ \\
\hline $\begin{array}{l}\text { Colistin/polymyxin } \\
\text { MIC }(\mu \mathrm{g} / \mathrm{ml})\end{array}$ & $4 / 4$ & $4 / 4$ & $4 / 4$ & $8 / 8$ & $4 / 4$ \\
\hline Resistance genotype & $\begin{array}{c}\text { mcr-1, bla } a_{\mathrm{CTX-М-8}} \\
\text { gnrB19, aadA2, } \\
\text { strA, strB, sul2 }\end{array}$ & $\begin{array}{c}\text { mcr-1, bla } a_{\mathrm{TEM}-1 \mathrm{~B}} \\
\text { gnrB19, catA1, } \\
\text { aadA1, strA, strB, } \\
\text { sul1, sul2, tetA, } \\
\text { dfrA1, dfrA8 }\end{array}$ & $\begin{array}{l}\text { mcr-1, bla } a_{\mathrm{CTX}-\mathrm{M}-1,} \\
\quad \operatorname{aad} A 1, \text { sul2, tet } A, \\
\quad \operatorname{tet} B\end{array}$ & $\begin{array}{l}\text { mcr-1, bla } a_{\mathrm{CTX}-\mathrm{M}-1}, \\
\quad \operatorname{aad} A 1, \text { sul2, tet } A, \\
\quad \operatorname{tet} B\end{array}$ & $m c r-1, b / a_{\mathrm{CTX}-\mathrm{M}-8}$ \\
\hline Plasmids (Inc) ${ }^{b}$ & I1, ColRNAI, X4 & FIB, Q1, X4 & HI2, I1, N, X4 & $\begin{array}{l}\text { FIN, HI2, HI2A, I1, } \\
\text { N, X4 }\end{array}$ & $11, \times 4$ \\
\hline
\end{tabular}

${ }^{a} E$. coli isolates ICBEC2AM, ICBEC3AM, and ICBEC13AM were analyzed in this study. Data for $E$. coli ICBEC7P and ICBEC72H were obtained from earlier studies by our group $(5,7)$. ST, sequence type; CC, clonal complex; AMK, amikacin; AMO, amoxicillin; AMP, ampicillin; ATM, aztreonam; CAZ, ceftazidime; CEF, cephalothin; CIP, ciprofloxacin; CLO, chloramphenicol; CRO, ceftriaxone; CTF, ceftiofur; CTX, cefotaxime; DOX, doxycycline; ENR, enrofloxacin; FEP, cefepime; GEN, gentamicin; NAL, nalidixic acid; SUL, sulfonamide; SXT, trimethoprim-sulfamethoxazole; TET, tetracycline.

${ }^{b}$ The replicon types of plasmids carrying the $\mathrm{mcr}-1$ gene are in bold.

groups. For comparative analysis, plasmid sequences were aligned against the nonredundant database using the MegaBLAST algorithm (NCBI BLAST), with default settings for the parameters. The plasmids pICBEC2AM and pICBEC3AM displayed $91 \%$ and $100 \%$ nucleotide identity, respectively, to the plasmid pICBEC72Hmcr (GenBank accession number CP015977), which originated from a human patient (5), and pICBEC13AM displayed $100 \%$ identity to the plasmid pICBEC7Pmcr (GenBank accession number CP017246), which was identified in the E. coli ST10 isolate from the infected penguin (7), confirming an epidemiological link (Table 1); IncX4 plasmids are key vectors responsible for dissemination of the $\mathrm{mcr}-1$ gene $(5,7,17)$.

The coexistence of $\mathrm{mcr}-1$ and/or plasmid-mediated quinolone resistance (PMQR) and ESBL-encoding genes, such as qnrB19 and bla ${ }_{\mathrm{CTX}-\mathrm{M}}$-type variants, is of great concern, because the occurrence of $\mathrm{mcr}-1$ and other clinically significant resistance genes in $E$. coli would seriously compromise treatment options (18). These results suggest that MCR-1-positive $E$. coli isolates are able to recruit other resistance genes, becoming MDR.

In summary, we report the occurrence of colistin-resistant, MCR-1-producing, E. coli lineages in recreational coastal waters of anthropogenically affected public beaches (19). In this situation, it is possible that residents, tourists, and wildlife could be exposed to this infectious threat directly from water exposure, from contact with sand, or through food consumption on the beach. Therefore, epidemiological studies addressing the consequences for human health of environmental dissemination of $E$. coli strains carrying the $m c r-1$ gene are necessary.

Accession number(s). Complete plasmid sequences were deposited in GenBank under accession numbers KY770023 (pICBEC2AM), KY770024 (pICBEC3AM), and KY770025 (pICBEC13AM).

\section{ACKNOWLEDGMENTS}

This work was supported by the Fundação de Amparo à Pesquisa do Estado de São Paulo (grant 2016/08593-9) and by the Conselho Nacional de Desenvolvimento Cientí- 
fico e Tecnológico (grant 462042/2014-6). M.R.F. and N.L. are research grant fellows of the Fundação de Amparo à Pesquisa do Estado de São Paulo and the Conselho

Nacional de Desenvolvimento Científico e Tecnológico, respectively.

We thank Cefar Diagnóstica (Brazil) for kindly supplying antibiotic discs for susceptibility testing.

We have no conflicts of interest to declare.

\section{REFERENCES}

1. Liu YY, Wang $Y$, Walsh TR, Yi LX, Zhang R, Spencer J, Doi Y, Tian G, Dong B, Huang X, Yu LF, Gu D, Ren H, Chen X, Lv L, He D, Zhou H, Liang Z, Liu $J H$, Shen J. 2016. Emergence of plasmid-mediated colistin resistance mechanism MCR-1 in animals and human beings in China: a microbiological and molecular biological study. Lancet Infect Dis 16:161-168. https://doi.org/10.1016/S1473-3099(15)00424-7.

2. Nordmann P, Poirel L. 2016. Plasmid-mediated colistin resistance: an additional antibiotic resistance menace. Clin Microbiol Infect 22: 398-400. https://doi.org/10.1016/j.cmi.2016.03.009.

3. Ovejero CM, Delgado-Blas JF, Calero-Caceres W, Muniesa M, GonzalezZorn B. 2017. Spread of mcr-1-carrying Enterobacteriaceae in sewage water from Spain. J Antimicrob Chemother 72:1050-1053. https://doi .org/10.1093/jac/dkw533.

4. Rapoport M, Faccone D, Pasteran F, Ceriana P, Albornoz E, Petroni A, MCR Group, Corso A. 2016. First description of $\mathrm{mcr}$-1-mediated colistin resistance in human infections caused by Escherichia coli in Latin America. Antimicrob Agents Chemother 60:4412-4413. https://doi.org/10 .1128/AAC.00573-16.

5. Fernandes MR, McCulloch JA, Vianello MA, Moura Q, Pérez-Chaparro PJ, Esposito F, Sartori L, Dropa M, Matté MH, Lira DP, Mamizuka EM, Lincopan N. 2016. First report of the globally disseminated IncX4 plasmid carrying the $\mathrm{mcr}-1$ gene in a colistin-resistant Escherichia coli sequence type 101 isolate from a human infection in Brazil. Antimicrob Agents Chemother 60:6415-6417. https://doi.org/10.1128/AAC.01325-16.

6. Ortega-Paredes D, Barba P, Zurita J. 2016. Colistin-resistant Escherichia coli clinical isolate harbouring the $\mathrm{mcr}-1$ gene in Ecuador. Epidemiol Infect 144:2967-2970. https://doi.org/10.1017/S0950268816001369.

7. Sellera FP, Fernandes MR, Sartori L, Carvalho MP, Esposito F, Nascimento CL, Dutra GH, Mamizuka EM, Pérez-Chaparro PJ, McCulloch JA, Lincopan N. 2017. Escherichia coli carrying IncX4 plasmid-mediated $\mathrm{mcr}-1$ and bla $a_{\text {СТХ-M }}$ genes in infected migratory Magellanic penguins (Spheniscus magellanicus). J Antimicrob Chemother 72:1255-1256. https://doi.org/ 10.1093/jac/dkw543.

8. Fernandes MR, Moura Q, Sartori L, Silva KC, Cunha MP, Esposito F, Lopes R, Otutumi LK, Gonçalves DD, Dropa M, Matté MH, Monte DF, Landgraf M, Francisco GR, Bueno MF, de Oliveira Garcia D, Knöbl T, Moreno AM, Lincopan N. 2016. Silent dissemination of colistin-resistant Escherichia coli in South America could contribute to the global spread of the $\mathrm{mcr}-1$ gene. Euro Surveill 21(17):pii=30214. https://doi.org/10.2807/1560-7917 ES.2016.21.17.30214

9. Clinical and Laboratory Standards Institute. 2014. Performance standards for antimicrobial susceptibility testing; 24th informational supplement. CLSI document M100-S24. Clinical and Laboratory Standards Institute, Wayne, PA.

10. European Committee on Antimicrobial Susceptibility Testing. 2016. Breakpoint tables for interpretation of MICs and zone diameters, version 6 www.eucast.org/fileadmin/src/media/PDFs/EUCAST_files/Breakpoint _tables/v_6.0_Breakpoint_table.pdf.
11. Maluta RP, Logue CM, Casas MR, Meng T, Guastalli EA, Rojas TC, Montelli AC, Sadatsune T, de Carvalho Ramos M, Nolan LK, da Silveira WD. 2014. Overlapped sequence types (STs) and serogroups of avian pathogenic (APEC) and human extra-intestinal pathogenic (ExPEC) Escherichia coli isolated in Brazil. PLoS One 9:e105016. https://doi.org/10.1371/journal .pone.0105016.

12. Mshana SE, Imirzalioglu C, Hain T, Domann E, Lyamuya EF, Chakraborty T. 2011. Multiple ST clonal complexes, with a predominance of ST131, of Escherichia coli harbouring bla $a_{\mathrm{CTX}-\mathrm{M}-15}$ in a tertiary hospital in Tanzania. Clin Microbiol Infect 17:1279-1282. https://doi.org/10.1111/j.1469-0691 .2011.03518.x.

13. Sun $P, B i Z$, Nilsson $M$, Zheng B, Berglund B, Stålsby Lundborg C, Börjesson S, Li X, Chen B, Yin H, Nilsson LE. 2017. Occurrence of bla $a_{\mathrm{KPC}-2^{\prime}}$ bla $a_{\mathrm{CTX}-\mathrm{M}}$ and $\mathrm{mcr}-1$ in Enterobacteriaceae from well water in rural China. Antimicrob Agents Chemother 61:e02569-16. https://doi.org/10.1128/ AAC.02569-16.

14. Guenther S, Falgenhauer L, Semmler T, Imirzalioglu C, Chakraborty T, Roesler U, Roschanski N. 2017. Environmental emission of multiresistant Escherichia coli carrying the colistin resistance gene $\mathrm{mcr}-1$ from German swine farms. J Antimicrob Chemother https://doi.org/10.1093/jac/ dkw585.

15. Wang Y, Zhang R, Li J, Wu Z, Yin W, Schwarz S, Tyrrell JM, Zheng Y, Wang S, Shen Z, Liu Z, Liu J, Lei L, Li M, Zhang Q, Wu C, Zhang Q, Wu Y, Walsh TR, Shen J. 2017. Comprehensive resistome analysis reveals the prevalence of NDM and MCR-1 in Chinese poultry production. Nat Microbiol 2:16260. https://doi.org/10.1038/nmicrobiol.2016.260.

16. El Garch F, Sauget M, Hocquet D, LeChaudee D, Woehrle F, Bertrand X. 2017. mcr-1 is borne by highly diverse Escherichia coli isolates since 2004 in food-producing animals in Europe. Clin Microbiol Infect 23: 51.e1-51.e4. https://doi.org/10.1016/j.cmi.2016.08.033.

17. Li R, Xie M, Zhang J, Yang Z, Liu L, Liu X, Zheng Z, Chan EW, Chen S. 2017. Genetic characterization of $\mathrm{mcr}$-1-bearing plasmids to depict molecular mechanisms underlying dissemination of the colistin resistance determinant. J Antimicrob Chemother 72:393-401. https://doi.org/10.1093/ jac/dkw411.

18. Wang $Y$, Tian GB, Zhang $R$, Shen $Y$, Tyrrell JM, Huang $X$, Zhou H, Lei L, Li HY, Doi Y, Fang Y, Ren H, Zhong LL, Shen Z, Zeng KJ, Wang S, Liu JH, Wu C, Walsh TR, Shen J. 2017. Prevalence, risk factors, outcomes, and molecular epidemiology of $\mathrm{mcr}$-1-positive Enterobacteriaceae in patients and healthy adults from China: an epidemiological and clinical study. Lancet Infect Dis 17:390-399. https://doi.org/10.1016/S1473 -3099(16)30527-8.

19. Lamparelli CC, Pogreba-Brown K, Verhougstraete M, Sato MI, Bruni Ade C, Wade TJ, Eisenberg JN. 2015. Are fecal indicator bacteria appropriate measures of recreational water risks in the tropics: a cohort study of beach goers in Brazil? Water Res 87:59-68. https://doi.org/10.1016/j.watres.2015 .09.001. 


\section{Chicken Meat as a Reservoir of Colistin- Resistant Escherichia coli Strains Carrying mor-1 Genes in South America}

\author{
Daniel Farias Monte, ${ }^{a, b}$ Andressa Mem, ${ }^{c}$ Miriam R. Fernandes, ${ }^{d}$ Louise Cerdeira, ${ }^{d}$ \\ Fernanda Esposito, d Julia A. Galvão,c Bernadette D. G. M. Franco,a,b \\ (D) Nilton Lincopan, d,e Mariza Landgrafa,b \\ Department of Food and Experimental Nutrition, School of Pharmacy, University of São Paulo, São Paulo, \\ Brazila; Food Research Center, University of São Paulo, São Paulo, Brazilb; Department of Veterinary Medicine, \\ Federal University of Paraná, Paraná, Brazilc; Department of Clinical Analysis, School of Pharmacy, University of \\ São Paulo, São Paulo, Brazild; Department of Microbiology, Institute of Biomedical Sciences, University of São \\ Paulo, São Paulo, Brazile
}

ABSTRACT The detection and rapid spread of colistin-resistant Enterobacteriaceae carrying the $m c r-1$ gene has created an urgent need to strengthen surveillance. In this study, eight clonally unrelated colistin-resistant Escherichia coli isolates carrying $m c r-1$ and $b l a_{\mathrm{CTX}-\mathrm{M}}$ or bla $a_{\mathrm{CMY}-2}$ genes were isolated from commercial chicken meat in Brazil. Most E. coli strains carried IncX4 plasmids, previously identified in human and animal isolates. These results highlight a new reservoir of $\mathrm{mcr}$-1-harboring $E$. coli strains in South America.

KEYWORDS mcr-1, ESBL, CTX-M-8, IncX4, Brazil, polymyxins

T he detection and rapid spread of colistin-resistant Escherichia coli isolates carrying the mcr-1 gene have created an urgent need to strengthen surveillance. Recently, mcr-1-harboring Enterobacteriaceae isolates were identified in food-producing animals, foods, aquatic environments, and humans (1-12). Although the $\mathrm{mcr}-1$ gene has spread rapidly in Asia, Europe, Africa, North America, and South America, few studies reported its presence in Enterobacteriaceae isolates from foods. So far, $\mathrm{mcr}$-1-positive E. coli strains have been described in meats or vegetables in Europe (4-7, 9-11), Asia (8), and North America (12). In this study, we report for the first time, to our knowledge, the identification of colistin-resistant $E$. coli strains carrying the $\mathrm{mcr}-1$ gene in commercial chicken meat in Latin America.

As part of a local investigation conducted to monitor the presence of colistinresistant bacteria carrying $\mathrm{mcr}-1$ in chicken meat sold in markets in São Paulo, southeastern Brazil, 41 samples, including breast $(n=20)$, thigh $(n=20)$, and liver $(n=1)$, were collected from 12 markets between August and October 2016. Samples (25 g) were dispensed in sterile plastic bags (Whirl-Pak; Nasco, Wl) containing $225 \mathrm{ml}$ of MacConkey broth and incubated at $37^{\circ} \mathrm{C}$ for $24 \mathrm{~h}$. After incubation, a 1-ml aliquot of MacConkey broth was serially diluted in buffered peptone water, inoculated onto MacConkey agar plates containing colistin ( $2 \mu \mathrm{g} / \mathrm{ml}$ ) (Sigma-Aldrich, St. Louis, MO), and incubated at $37^{\circ} \mathrm{C}$ for $24 \mathrm{~h}$ (13). Next, antimicrobial susceptibility profiles and MIC values of polymyxin B and colistin were determined by disk diffusion (14) and a microdilution method (15), respectively; $m c r-1$, extended-spectrum $\beta$-lactamase (ESBL), and plasmidmediated AmpC $\beta$-lactamase genes were screened by PCR and sequencing $(1,16)$.

Eight colistin-resistant $E$. coli isolates from chicken meat samples (19.5\%), collected from markets located in the north, south, and west regions of São Paulo, tested positive for mcr-1 and bla $a_{\mathrm{CTX}-\mathrm{M}}$ or bla $a_{\mathrm{CMY}-2}$ genes (Table 1). These isolates were found to be genetically unrelated by pulsed-field gel electrophoresis (PFGE) (17) and were not
Received 23 December 2016 Returned for modification 9 January 2017 Accepted 8 February 2017

Accepted manuscript posted online 13 February 2017

Citation Monte DF, Mem A, Fernandes MR, Cerdeira L, Esposito F, Galvão JA, Franco BDGM, Lincopan N, Landgraf M. 2017. Chicken meat as a reservoir of colistin-resistant Escherichia coli strains carrying mcr-1 genes in South America. Antimicrob Agents Chemother 61:e02718-16. https://doi.org/10.1128/AAC.02718-16. Copyright $\odot 2017$ American Society for Microbiology. All Rights Reserved. Address correspondence to Nilton Lincopan, lincopan@usp.br. 


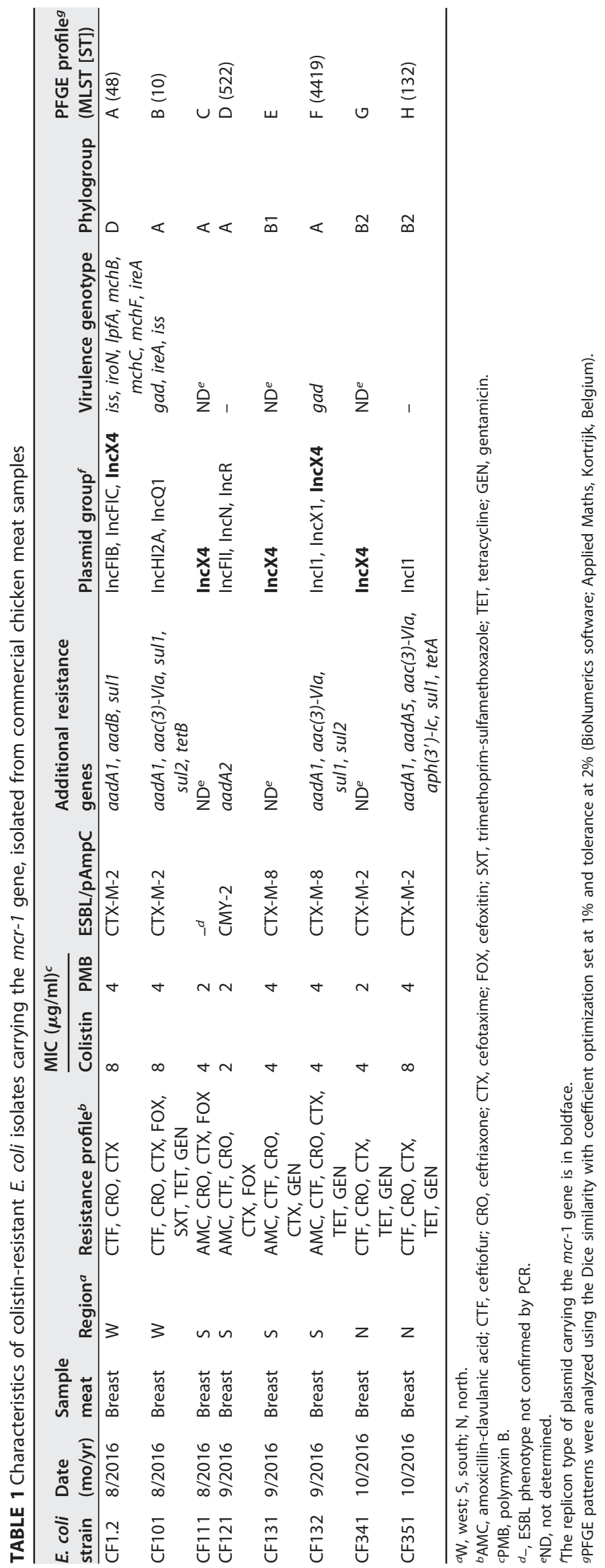


related to other $m c r-1$-positive $E$. coli isolates previously identified in food-producing animals (2) and humans (3) in Brazil. However, plasmid characterization by PCR-based replicon typing revealed the presence of IncX4-type plasmids in five $m c r$-1-positive $E$. coli isolates (Table 1) (18), which has been reported globally (3).

Genomic DNA from five representative colistin-resistant $E$. coli isolates (CF1.2, CF101, CF121, CF132, CF351) was extracted to construct a Nextera XT DNA library, which was sequenced using the MiSeq v3 platform (Illumina, San Diego, CA) with paired-end reads (300bp). De novo assembly was performed using the A5-MiSeq pipeline, and this assembly was optimized using Geneious vR9 (Biomatters, Ltd., New Zealand). Serotypes, MLST, plasmid replicons, antimicrobial resistance genes, and $E$. coli virulence genes were identified using multiple databases, including SerotypeFinder 1.1, MLST 1.8, PlasmidFinder 1.3, ResFinder 2.1, and VirulenceFinder 1.5, respectively, available from the Center for Genomic Epidemiology (http://genomicepidemiology.org/).

Most E. coli isolates exhibited an MDR phenotype, and, indeed, clinically important genes conferring resistance to aminoglycosides, quinolones, sulfonamide, and tetracyclines were identified by whole-genome sequencing (Table 1). On the other hand, MLST analysis from sequence reads identified the sequence types ST132, ST48, ST4419, ST522, and ST10 (Table 1). In particular, the ST10 has been widely identified in animal, food, human, and environmental samples and associated with the production of CTX-M-type ESBLs and, more recently, the MCR-1 enzyme, denoting great versatility of this lineage for adaptation to different hosts (3, 19-23). Furthermore, the presence of IncX4 plasmids carrying the mcr-1 gene in E. coli isolates CF1.2, CF131, and CF132 was confirmed, as previously reported in human and animal clinical samples collected in this region $(3,19)$. In this regard, contigs of 5,545 kbp containing the $\mathrm{mcr}-1$ gene were found to bear an IncX4 replicon signature, as determined by the PlasmidFinder database (https://cge.cbs.dtu.dk/services/PlasmidFinder/). Moreover, these contigs were found to host a hit showing 100\% identity to another IncX4 plasmid harboring mcr-1 (GenBank accession no. CP015977). CTX-M-type encoding genes were not located in the same plasmid that carried the $m c r-1$ gene. In fact, IncX4 plasmids have been associated with only the mobilization of $\mathrm{mcr}-1$ (24).

Colistin has been widely used in animal feed as a growth promoter in Brazilian livestock, mainly pigs and poultry. In 2008, the Ministry of Agriculture, Livestock, and Supply (MAPA) established appropriate levels for colistin use in broilers (2 to $10 \mathrm{~g} / \mathrm{ton}$ of feed), poultry (4 to $10 \mathrm{~g} /$ ton of feed), pigs (20 to $40 \mathrm{~g} / \mathrm{ton}$ of feed), and cattle (5 to $40 \mathrm{~g} /$ ton of feed). However, after the presence of colistin-resistant $E$. coli carrying the mcr-1 gene was confirmed in humans and animals (including livestock), the use of colistin in animal feed was banned by MAPA (regulatory instruction no. 45 [http:// www.agricultura.gov.br/]) in November 2016, following the international recommendations of the World Health Organization.

In summary, these results highlight that commercial chicken meat can be an important reservoir of $m c r-1$-carrying $E$. coli isolates, which is a cause for public health concern, since this could contribute to acceleration of the spread of the $\mathrm{mcr}-1$ gene. In fact, in the agribusiness, Brazil is the third-largest chicken meat producer and the largest exporter of this product, with high domestic consumption (25). Finally, the occurrence of $E$. coli isolates carrying the $\mathrm{mcr}^{-1}$ gene in chicken meat could be favored by the versatility of $E$. coli, i.e., host adaptability, ubiquity, and persistence along the food chain; IncX4 plasmids might be key vectors responsible for the dissemination of this gene. So, surveillance of colistin-resistant E. coli carrying the $\mathrm{mcr}^{-1}$ gene in the food chain needs to be established as a priority, to prevent their spread.

Accession number(s). Partial IncX4 plasmid sequences were deposited in the GenBank database under accession numbers KY550358 (pCF1-2), KY550357 (pCF131), and KY550359 (pCF132).

\section{ACKNOWLEDGMENTS}

This work was supported by research grants from Coordenação de Aperfeiçoamento de Pessoal de Nível Superior (CAPES), Fundação de Amparo à Pesquisa do Estado de 
São Paulo (FAPESP), and Conselho Nacional de Desenvolvimento Científico e Tecnológico (CNPq). N.L. is a research grant fellow of CNPq.

This work was funded by research grants from FAPESP (2013/07914-8 and 2016/

08593-9) and CNPq (470956/2013-5).

We have no conflicts of interest to declare.

\section{REFERENCES}

1. Liu YY, Wang Y, Walsh TR, Yi LX, Zhang R, Spencer J, Doi Y, Tian G, Dong B, Huang X, Yu LF, Gu D, Ren H, Chen X, Lv L, He D, Zhou H, Liang Z, Liu $J H$, Shen J. 2016. Emergence of plasmid-mediated colistin resistance mechanism MCR-1 in animals and human beings in China: a microbiological and molecular biological study. Lancet Infect Dis 16:161-168. https://doi.org/10.1016/S1473-3099(15)00424-7.

2. Fernandes MR, Moura Q, Sartori L, Silva KC, Cunha MP, Esposito F, Lopes R, Otutumi LK, Gonçalves DD, Dropa M, Matté MH, Monte DF, Landgraf M, Francisco GR, Bueno MF, de Oliveira Garcia D, Knöbl T, Moreno AM, Lincopan N. 2016. Silent dissemination of colistinresistant Escherichia coli in South America could contribute to the global spread of the $m c r-1$ gene. Euro Surveill 21(17). http:// www.eurosurveillance.org/ViewArticle.aspx?Articleld $=22458$.

3. Fernandes MR, McCulloch JA, Vianello MA, Moura Q, Pérez-Chaparro PJ, Esposito F, Sartori L, Dropa M, Matté MH, Lira DPA, Mamizuka EM, Lincopan N. 2016. First report of the globally disseminated IncX4 plasmid carrying the $m c r-1$ gene in a colistin-resistant Escherichia coli sequence type 101 isolate from a human infection in Brazil. Antimicrob Agents Chemother 60:6415-6417. https://doi.org/10.1128/AAC .01325-16.

4. Schwarz S, Johnson AP. 2016. Transferable resistance to colistin: a new but old threat. J Antimicrob Chemother 71:2066-2070. https://doi.org/ 10.1093/jac/dkw274.

5. Hasman H, Hammerum A, Hansen F, Hendriksen R, Olesen B, Agers $\varnothing$ Y, Zankari E, Leekitcharoenphon P, Stegger M, Kaas R, Cavaco L, Hansen D, Aarestrup F, Skov R. 2015. Detection of $\mathrm{mcr}-1$ encoding plasmid-mediated colistin-resistant Escherichia coli isolates from human bloodstream infection and imported chicken meat, Denmark 2015. Euro Surveill 20(49). http://www.eurosurveillance.org/View Article.aspx?Articleld $=21331$.

6. Zurfuh K, Poirel L, Nordmann P, Nüesch-Inderbinen M, Hächler $H$, Stephan R. 2016. Occurrence of the plasmid-borne $\mathrm{mcr}-1$ colistin resistance gene in extended-spectrum- $\beta$-lactamase-producing Enterobacteriaceae in river water and imported vegetable samples in Switzerland. Antimicrob Agents Chemother 60:2594-2595. https://doi.org/10.1128/ AAC.00066-16.

7. Kluytmans-van den Bergh $M$, Huizinga $P$, Bonten $M$, Bos $M$, De Bruyne $K$, Friedrich A, Rossen J, Savelkoul P, Kluytmans J. 2016. Presence of $\mathrm{mcr}$ 1-positive Enterobacteriaceae in retail chicken meat but not in humans in the Netherlands since 2009. Euro Surveill 21(9). http:// www.eurosurveillance.org/ViewArticle.aspx?Articleld =21396.

8. Kuo SC, Huang WC, Wang HY, Shiau YR, Cheng MF, Lauderdale TL. 2016. Colistin resistance gene $\mathrm{mcr}-1$ in Escherichia coli isolates from humans and retail meats, Taiwan. J Antimicrob Chemother 71:2327-2329. https://doi.org/10.1093/jac/dkw122.

9. Doumith M, Godbole G, Ashton P, Larkin L, Dallman T, Day M, Day M, Muller-Pebody B, Ellington MJ, de Pinna E, Johnson AP, Hopkins KL, Woodford N. 2016. Detection of the plasmid-mediated $\mathrm{mcr}^{-1}$ gene conferring colistin resistance in human and food isolates of Salmonella enterica and Escherichia coli in England and Wales. J Antimicrob Chemother 71:2300-2305. https://doi.org/10.1093/jac/dkw093.

10. Zurfluh K, Klumpp J, Nüesch-Inderbinen M, Stephan R. 2016. Full-length nucleotide sequences of mcr-1-harboring plasmids isolated from extended-spectrum- $\beta$-lactamase-producing Escherichia coli isolates of different origins. Antimicrob Agents Chemother 60:5589-5591. https:// doi.org/10.1128/AAC.00935-16.

11. Irrgang A, Roschanski N, Tenhagen BA, Grobbel M, SkladnikiewiczZiemer T, Thomas K, Roesler U, Käsbohrer A. 2016. Prevalence of $\mathrm{mcr}-1$ in E. coli from livestock and food in Germany, 2010-2015. PLoS One 11:e0159863. https://doi.org/10.1371/journal.pone.0159863.

12. Mulvey MR, Mataseje LF, Robertson J, Nash JH, Boerlin P, Toye B, Irwin R, Melano RG. 2016. Dissemination of the $\mathrm{mcr}-1$ colistin resistance gene.
Lancet Infect Dis 16:289-290. https://doi.org/10.1016/S1473 -3099(16)00067-0.

13. U.S. Food and Drug Administration. 2012. NARMS retail meat annual report. U.S. Food and Drug Administration, Rockville, MD.

14. Clinical and Laboratory Standards Institute. 2014. Performance standards for antimicrobial susceptibility testing; 24th informational supplement. CLSI document M100-S24. Clinical and Laboratory Standards Institute, Wayne, PA.

15. European Committee on Antimicrobial Susceptibility Testing. 2016. EUCAST clinical breakpoints. http://www.eucast.org/clinical _breakpoints/.

16. Dropa M, Lincopan N, Balsalobre LC, Oliveira DE, Moura RA, Fernandes MR, da Silva QM, Matté GR, Sato MI, Matté MH. 2016. Genetic background of novel sequence types of CTX-M-8- and CTX-M-15-producing Escherichia coli and Klebsiella pneumoniae from public wastewater treatment plants in São Paulo, Brazil. Environ Sci Pollut Res Int 23:4953-4958. https://doi.org/10.1007/s11356-016-6079-5.

17. Ribot EM, Fair MA, Gautom R, Cameron DN, Hunter SB, Swaminathan B, Barrett TJ. 2006. Standardization of pulsed-field gel electrophoresis protocols for the subtyping of Escherichia coli 0157:H7, Salmonella, and Shigella for PulseNet. Foodborne Pathog Dis 3:59-67. https://doi.org/10 .1089/fpd.2006.3.59.

18. Johnson TJ, Bielak EM, Fortini D, Hansen LH, Hasman H, Debroy C, Nolan LK, Carattoli A. 2012. Expansion of the IncX plasmid family for improved identification and typing of novel plasmids in drug-resistant Enterobacteriaceae. Plasmid 68:43-50. https://doi.org/10.1016/j.plasmid.2012.03 .001 .

19. Sellera FP, Fernandes MR, Sartori L, Carvalho MPN, Esposito F, Nascimento CL, Dutra GHP, Mamizuka EM, Pérez-Chaparro PJ, McCulloch JA, Lincopan N. 2016. Escherichia coli carrying IncX4 plasmid-mediated $m c r-1$ and bla $a_{\text {СтX-M }}$ genes in infected migratory Magellanic penguins (Spheniscus magellanicus). J Antimicrob Chemother:pii:dkw543. https:// doi.org/10.1093/jac/dkw543.

20. Day MJ, Rodríguez I, van Essen-Zandbergen A, Dierikx C, Kadlec K, Schink AK, Wu G, Chattaway MA, Do Nascimento V, Wain J, Helmuth R, Guerra B, Schwarz S, Threlfall J, Woodward MJ, Coldham N, Mevius D, Woodford N. 2016. Diversity of STs, plasmids and ESBL genes among Escherichia coli from humans, animals and food in Germany, the Netherlands and the UK. J Antimicrob Chemother 71:1178-1182. https://doi.org/10.1093/ jac/dkv485.

21. El Garch F, Sauget M, Hocquet D, LeChaudee D, Woehrle F, Bertrand X. 2016. mcr-1 is borne by highly diverse Escherichia coli isolates since 2004 in food-producing animals in Europe. Clin Microbiol Infect 23:51.e151.e4. https://doi.org/10.1016/j.cmi.2016.08.033.

22. Sun $P, B i$, Nilsson $M$, Zheng B, Berglund B, Stålsby Lundborg $C$, Börjesson S, Li X, Chen B, Yin H, Nilsson LE. 2017. Occurrence of blaKPC-2, blaCTX-M and $m c r-1$ in Enterobacteriaceae from Well Water in rural China. Antimicrob Agents Chemother pii:AAC.02569-16. https://doi .org/10.1128/AAC.02569-16.

23. Guenther S, Falgenhauer L, Semmler T, Imirzalioglu C, Chakraborty T, Roesler U, Roschanski N. 2017. Environmental emission of multiresistant Escherichia coli carrying the colistin resistance gene $\mathrm{mcr}-1$ from German swine farms. J Antimicrob Chemother pii:dkw585. https://doi.org/10 .1093/jac/dkw585.

24. Li R, Xie M, Zhang J, Yang Z, Liu L, Liu X, Zheng Z, Chan EW, Chen S. 2017. Genetic characterization of $\mathrm{mcr}$-1-bearing plasmids to depict molecular mechanisms underlying dissemination of the colistin resistance determinant. J Antimicrob Chemother 72:393-401. https://doi.org/10.1093/ jac/dkw411.

25. U.S. International Trade Commission. 2012. Brazil: competitive factors in brazil affecting U.S. and Brazilian agricultural sales in selected third country markets. Publication 4310. U.S. International Trade Commission, Washington, DC. https://www.usitc.gov/publications/332/pub4310.pdf. 
J Antimicrob Chemother

doi:10.1093/jac/dky341

\section{Novel $\mathrm{mcr}-5.3$ variant in a CTX-M-8-producing Escherichia coli ST711 isolated from an infected horse}

\author{
Miriam R. Fernandes $\mathbb{D}^{1}{ }^{1}$, Louise Cerdeira ${ }^{1}$, \\ Meire M. Silva ${ }^{2}$, Fábio P. Sellera ${ }^{3}$, Maria Muñoz ${ }^{1}$, \\ Felicio G. Junior ${ }^{2}$, Sergio S. Azevedo ${ }^{2}$, Pablo Power ${ }^{4,5}$, \\ Gabriel Gutkind ${ }^{4,5}$ and Nilton Lincopan (D) ${ }^{1,6 *}$
}

\begin{abstract}
${ }^{1}$ Department of Clinical Analysis School of Pharmacy, Universidade de São Paulo, São Paulo, Brazil; ${ }^{2}$ Academic Unit of Veterinary Medicine, Universidade Federal de Campina Grande, Patos, Paraíba, Brazil; ${ }^{3}$ Department of Internal Medicine School of Veterinary Medicine and Animal Science, University of São Paulo, São Paulo, Brazil; ${ }^{4}$ Cátedra de Microbiología, Departmento de Microbiología, Inmunología y Biotecnología, Facultad de Farmacia y Bioquímica, Universidad de Buenos Aires, Buenos Aires, Argentina; ${ }^{5}$ Consejo Nacional de Investigaciones Científicas y Técnicas (CONICET), Buenos Aires, Argentina; ${ }^{6}$ Department of Microbiology, Institute of Biomedical Sciences University of São Paulo, São Paulo, Brazil
\end{abstract}

${ }^{*}$ Corresponding author. Tel: +55-11-3091-7296; Fax: +55-11-30917354; E-mail: lincopan@usp.br (1) orcid.org/0000-0003-0161-5800

\section{Sir,}

Following the first description of the mobile phosphoethanolamine transferase gene mcr-1, responsible for transferable colistin resistance in Enterobacteriaceae of human and animal origin, a rapid dissemination and emergence of novel mer variants has been globally described. ${ }^{1-5}$ In this regard, two recent reports published in JAC have documented the identification of novel mcr-5 and mcr5.2 gene variants in $d$-tartrate fermenting Salmonella enterica subsp. enterica serovar Paratyphi B and Escherichia coli from food and food-producing animals, respectively, in Germany. Interestingly, $\mathrm{mcr}-5$ has also been identified in E. coli isolates from diseased pigs in Japan $^{6}$ and from animals and the human vaginal microbiome in China. ${ }^{7,8}$ In this study, we report the occurrence of a novel variant of $\mathrm{mcr}-5$ (mcr-5.3) in South America.

A retrospective genomic study led to the identification of a CTXM-8-producing E. coli isolate (ECPB39) carrying an mcr-5-type gene, from a diseased horse that died due to pneumonia. Veterinary medical records revealed that E. coli ECPB39 was isolated in 2012, from a lung tissue culture obtained at necropsy, in a veterinary hospital in north-eastern Brazil. This strain exhibited an MDR profile including ampicillin, amoxicillin/clavulanic acid, ceftiofur, ceftriaxone, cefotaxime (>32 mg/L), cefepime, amikacin, gentamicin, trimethoprim/sulfamethoxazole and tetracycline, but remained susceptible to cefoxitin, ciprofloxacin, enrofloxacin, ertapenem, imipenem and meropenem (http://www.eucast.org/). ESBL production was confirmed by using a double-disc synergy test, whereas ESBL genes were screened for by PCR and Sanger

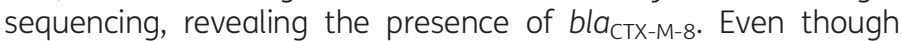
ECPB39 exhibited a colistin MIC of $2 \mathrm{mg} / \mathrm{L}$ (http://www.eucast.org/), it showed a positive result in the rapid polymyxin NP test, ${ }^{9}$ which was reverted in the presence of EDTA. ${ }^{10}$

Whole genomic DNA was extracted (PureLink ${ }^{\mathrm{TM}}$; Invitrogen) and used to prepare a library that was sequenced using the NextSeq550 platform ( $2 \times 75$ bp paired-end) (Illumina). De novo assemblies were accomplished by using the CLC Genomic Workbench 10.0. Multilocus STs, serotypes, virulomes, resistomes and incompatibility plasmid groups were screened for using bioinformatics tools available from the Center for Genomic Epidemiology (http://genomicepidemiology.org/).

WGS analysis revealed that ECPB39 belonged to serotype O45:H20 and ST711, the latter described in the E. coli MLST database as a human, animal, food and environmental pathogen in countries throughout Europe and North America (http://entero base.warwick.ac.uk/). Regarding virulence, the presence of gad (glutamate decarboxylase), IpfA (long polar fimbriae) and iss (increased serum survival) genes was found. The resistome analysis identified the presence of genes conferring resistance to $\beta$-lactams (bla CTX-M-8 $_{\text {and }}$ ala $a_{\text {TEM-1B }}$ ), aminoglycosides [aac(3)-IId, aadA2, strA and strB], sulphonamides (sul2) trimethoprim (dfrA12) and polymyxins (mcr-5-type).

E. coli ECPB39 harboured IncI1, IncHI1A, IncQ1, IncFIB, IncFIA and IncFII plasmids. For plasmid assembly, a de novo strategy was used in combination with manual curation. In this regard, a novel 5361 bp plasmid (pECPB39, belonging to an unknown replicon type) carrying the mcr-5-type gene could be identified. It incorporated the complete backbone of the pKP13a plasmid (2459 bp, GenBank accession number (P003996), as previously observed, ${ }^{4}$ with a mobilization gene and two hypothetical proteins (Figure 1a). The mcr-type gene (1644bp), termed as mcr-5.3type, ${ }^{2}$ showed $99.9 \%$ sequence identity (G1240T) to $\mathrm{mcr}-5$, resulting in $7479 \times$ mutation coverage (i.e. number of reads mapping at that position). Therefore, the MCR-5.3 variant differed by one amino acid (Ala414Ser) from MCR-5 and MCR-5.2 (Figure 1b). The mutation was confirmed by Sanger sequencing, using primers mcr-5.3 F (5'-CGATAACCAGTCGGGCTGTA-3') and mcr-5.3 R

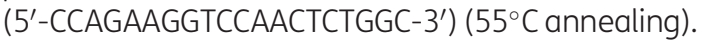

Based on a previous analysis of the mcr-5.2 variant, ${ }^{4}$ the genetic context of mcr-5.3 revealed that pSE13-SA01718 (KY807921), pEC1066 (MG587003) and pEC2380 (MG587004) carried the same transposon (Tn3-type), differing only by the ProP protein present in Cupriavidus gilardii CR3 (CP010516) (Figure S1, available as Supplementary data at JAC Online). ${ }^{3,4}$ On the other hand, pECPB39 (MG886287) and pEC0674 (MF684783) plasmids lack tnpA and tnpR of the mcr- 5 transposon. While the plasmid carrying the $\mathrm{mcr}$ 5.3 gene could not be transferred by conjugation (using MacConkey plates supplemented with $200 \mathrm{mg} / \mathrm{L}$ streptomycin and 0.5 or $1 \mathrm{mg} / \mathrm{L}$ colistin), an IncI1/ST113 plasmid (90 kb) carrying

(c) The Author(s) 2018. Published by Oxford University Press on behalf of the British Society for Antimicrobial Chemotherapy. All rights reserved. For permissions, please email: journals.permissions@oup.com. 
(a)

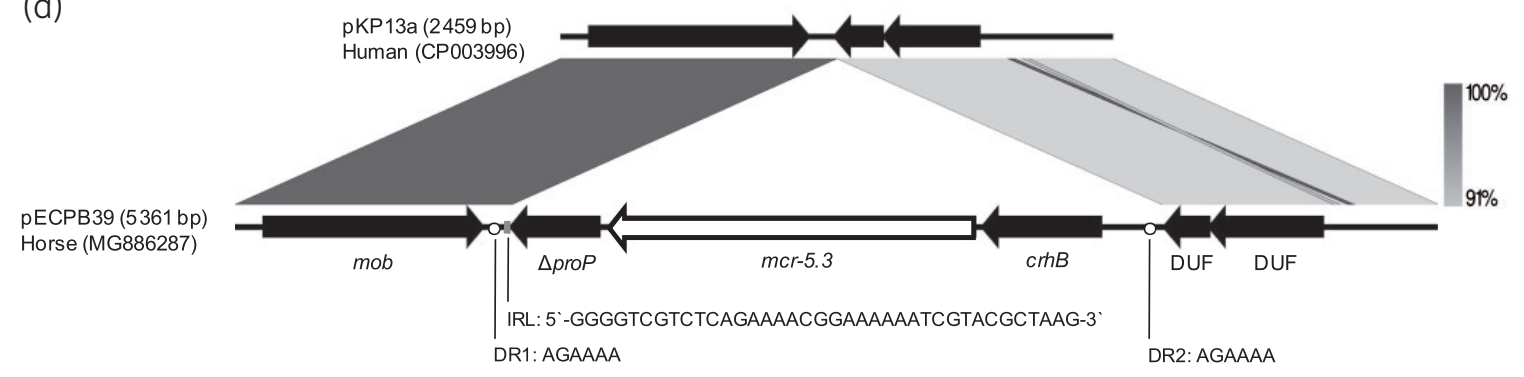

(b)

\begin{tabular}{|c|c|}
\hline $\begin{array}{l}\mathrm{MCR}-5 \\
\mathrm{MCR}-5.2 \\
\mathrm{MCR}-5.3\end{array}$ & $\begin{array}{l}\text { MRLSAFITFLKMRPQVRTEFLTLF ISLVFTLLCNGVFWNALLAGRDSLTSGTWLMLLCTG } \\
\text { MRLSAFITFLKMRPQVRTEFLTLFISLVFTLLCNGVFWNALLAGRDSLTSGTWLMLLCTG } \\
\text { MRLSAFITFLKMRPQVRTEFLTLF ISLVFTLLNGVFWALLAGRDSLTSGTWLMLLCTG }\end{array}$ \\
\hline $\begin{array}{l}\text { MCR }-5 \\
\text { MCR }-5.2 \\
\text { MCR }-5.3\end{array}$ & $\begin{array}{l}\text { LLITGLQWLLLLLVATRWSVKPLLILLAVMTPAAVYFMRNYGVYLDKAMLRNLMETDVRE } \\
\text { LLITGLQWLLLLLVATRWSVKPLLILLAVMTPAAVY FMRNYGVYLDKAMLRNLMETDVRE } \\
\text { LLITGLQWLLLLLVATRWSVKPLLILLAVMTPAAVYFMRNYGVYLDKAMLRNLMETDVRE }\end{array}$ \\
\hline $\begin{array}{l}\text { MCR }-5 \\
\text { MCR }-5.2 \\
M C R-5.3\end{array}$ & $\begin{array}{l}\text { ASELLQWRML PY LLVAAVSVWWIARVRVLRTGWKQAVMMRSACLAGALAMI SMGLWPVMD } \\
\text { ASELLQWRML PYLLVAAVSVWWIARVRVLRTGWKQAVMMRSACLAGALAMI SMGLWPVMD } \\
\text { ASELLQWRML PYLLVAAVSVWWIARVRVLRTGWKQAVMMRSACLAGALAMISMGLWPVMD }\end{array}$ \\
\hline $\begin{array}{l}\text { MCR }-5 \\
\text { MCR }-5.2 \\
\text { MCR }-5.3\end{array}$ & $\begin{array}{l}\text { VLIPTLRENKPLRYLITPANYVISGIRVLTEQASS SADEAREVVAADAHRGPQEQGRRPR } \\
\text { VLIPTLRENKPLRYLITPANYVISGIRVLTEQASSSADEAREVVAADAHRGPQ-QGRRPR } \\
\text { VLIPTLRENKPLRYLITPANYVISGIRVLTEQASSSADEAREVVAADAHRGPQEQGRRPR }\end{array}$ \\
\hline $\begin{array}{l}\text { MCR }-5 \\
\text { MCR }-5.2 \\
\text { MCR }-5.3\end{array}$ & $\begin{array}{l}\text { ALVLVVGETVRAANWGLSGYERQTTPELAARDVINFSDVTSCGTDTATS LPCMFS LNGRR } \\
\text { ALVLVVGETVRAANWGLSGYERQTTPELAARDVINFSDVTSCGTDTATS LPCMF SLNGRR } \\
\text { ALVLVVGETVRAANWGLSGYERQTTPELAARDVINFSDVTSCGTDTATSLPCMFSLNGRR }\end{array}$ \\
\hline $\begin{array}{l}\text { MCR }-5 \\
\text { MCR }-5.2 \\
\text { MCR }-5.3\end{array}$ & $\begin{array}{l}\text { DYDERQIRRRESVLHVLNRSDVNI LWRDNQSGCKGVCDGLPFENLSSAGHPTLCHGERCL } \\
\text { DYDERQIRRRESVLHVLNRSDVNI LWRDNQSGCKGVCDGLPFENLSSAGHPTLCHGERCL } \\
\text { DYDERQIRRRESVLHVLNRSDVNI LWRDNQSGCKGVCDGLPFENLSSAGHPTLCHGERCL }\end{array}$ \\
\hline $\begin{array}{l}\mathrm{MCR}-5 \\
\mathrm{MCR}-5.2 \\
\mathrm{MCR}-5.3\end{array}$ & $\begin{array}{l}\text { DEILLEGLAEKITTSRSDMLIVLHMLGNHGPAYFQRYPASYRRWS PTCDTTDLASCSHEA } \\
\text { DEILLEGLAEKITTSRSDMLIVLHMLGNHGPAYFQRYPASYRRWSPTCDTTDLASCSHEA } \\
\text { DEILLEGLAEKITTSRDMLIVLHMLGNHGPAYFQRYPASYRRWSPTCDTTDLSSCSHEA }\end{array}$ \\
\hline $\begin{array}{l}\text { MCR }-5 \\
\text { MCR }-5.2 \\
\text { MCR }-5.3\end{array}$ & $\begin{array}{l}\text { LVNTYDNAVLYTDHVLARTIDLLSGIRSHDTALLYVSDHGESLGEKGLYLHGIPYVIAPD } \\
\text { LVNTYDNAVLYTDHVLARTIDLLSGIRSHDTALLYVSDHGESLGEKGLYLHGIPYVIAPD } \\
\text { LVNTYDNAVLYTDHLARTIDLLSGIRSHDTALLYSDHGESLGEKGLYLHGIPYVIAPD }\end{array}$ \\
\hline $\begin{array}{l}\text { MCR }-5 \\
\text { MCR }-5.2 \\
M C R-5.3\end{array}$ & $\begin{array}{l}\text { EQIKVPMIWWQS SQVYADQACMQTHASRAPVSHDHLFHTLLGMFDVKTAAYTPELDLLAT } \\
\text { EQIKVPMIWWQS SQVYADQACMQTHASRAPVSHDHLFHTLLGMFDVKTAAYTPELDLLAT } \\
\text { EQIKVPMIWWQS SQVYADQACMQTHASRAPVSHDHLFHTLGMFDVKTAAYTPELDLLAT }\end{array}$ \\
\hline $\begin{array}{l}\text { MCR }-5 \\
\text { MCR }-5.2 \\
\text { MCR }-5.3\end{array}$ & $\begin{array}{l}\text { CRKGQPQ } \\
\text { CRKGQPQ } \\
\text { CRKGQPQ }\end{array}$ \\
\hline
\end{tabular}

Figure 1. (a) Genetic backbone of pECPB39 (MG886287) and pKP13a (CP003996) plasmids. In pECPB39, the $\Delta$ proP-mcr-5.3-chrB array has been incorporated into the pKP13a backbone. In fact, the mcr-5.3 gene is embedded within a Tn3-family transposon with a 38 bp IRL, as previously reported. ${ }^{3}$ DUF, domain of unknown function proteins. (b) Comparison of MCR-5-type phosphoethanolamine transferase proteins of S. enterica subsp. enterica serovar Paratyphi B and E. coli strains identified in Germany ${ }^{3,4}$ and Brazil (this study). The position of the amino acid deletion in MCR-5.2 (Glu233) is indicated by a dash (highlighted in grey), whereas the amino acid substitution in MCR-5.3 (Ala414Ser) is indicated in bold (highlighted in grey).

bla $_{\mathrm{CTX}-\mathrm{M}-8}$ was transferred to the recipient streptomycin-resistant E. colic $600^{\text {STR }}$.

Although, E. coli ECPB39 was susceptible to colistin (MIC $2 \mathrm{mg} / \mathrm{L}$, just below the EUCAST breakpoint), in silico structural analysis of MCR-5.3 revealed that the Ala414Ser mutation would not have a significant impact on the overall architecture of the catalytic domain, where zinc ions and residues seem to remain conserved and properly coordinated in comparison to MCR-1, despite the low amino acid identity (Figure S2). Thus, the identification of an mcr-5-positive isolate showing a colistin MIC of $2 \mathrm{mg} / \mathrm{L}$, in the present study, indicates that the silent spread of this gene might happen. Indeed, some E. coli isolates carrying the mcr-1, mcr-3 or mcr-5 gene have showed lower colistin MICs. ${ }^{6,11-13}$

In conclusion, we report the identification of a novel variant of mcr-5 in a CTX-M-8-producing E. coli from an infected horse, which had not received colistin previously. These results suggest that mcr-5 variant genes have been present in the South American veterinary scenario for at least 6 years, highlighting an urgent need to monitor plasmid-mediated mcr-type genes in human and veterinary medicine. 


\section{Nucleotide sequence accession number}

The nucleotide sequence of pECPB39 has been deposited at GenBank under the accession number MG886287.

\section{Acknowledgements}

FAPESP (2016/08593-9) and CNPq (462042/2014-6) research grants are gratefully acknowledged. We thank Cefar Diagnóstica Ltda (Brazil) for kindly supplying antibiotic discs for susceptibility testing.

\section{Funding}

This work was funded by research grants from Fundação de Amparo à Pesquisa do Estado de São Paulo (FAPESP; 2016/08593-9) and Conselho Nacional de Desenvolvimento Científico e Tecnológico (CNPq; 462042/2014-6). M. R. F. and L. C. are research fellows of FAPESP (2015/13527-2 and 2015/21325-0). N. L. is a research fellow of CNPa (312249/2017-9).

\section{Transparency declarations}

None to declare.

\section{Supplementary data}

Figures S1 and S2 are available as Supplementary data at JAC Online.

\section{References}

1 Liu YY, Wang Y, Walsh TR et al. Emergence of plasmid-mediated colistin resistance mechanism MCR-1 in animals and human beings in China: a microbiological and molecular biological study. Lancet Infect Dis 2016; 16: 161-8.
2 Partridge SR, Di Pilato V, Doi Y et al. Proposal for assignment of allele numbers for mobile colistin resistance ( $\mathrm{mcr}$ ) genes. J Antimicrob Chemother 2018; 73: 2625-30.

3 Borowiak M, Fischer J, Hammerl JA et al. Identification of a novel transposon-associated phosphoethanolamine transferase gene, mcr-5, conferring colistin resistance in $d$-tartrate fermenting Salmonella enterica subsp. enterica serovar Paratyphi B. J Antimicrob Chemother 2017; 72: 3317-24.

4 Hammerl JA, Borowiak M, Schmoger S et al. mcr-5 and a novel mcr-5.2 variant in Escherichia coli isolates from food and food-producing animals, Germany, 2010 to 2017. J Antimicrob Chemother 2018; 73: 1433-5.

5 Yang YQ, Li YX, Lei CW et al. Novel plasmid-mediated colistin resistance gene mcr-7.1 in Klebsiella pneumoniae. J Antimicrob Chemother 2018; 73 1791-5.

6 Fukuda A, Sato T, Shinagawa M et al. High prevalence of mcr-1, mcr-3 and mcr-5 in Escherichia coli derived from diseased pigs in Japan. Int J Antimicrob Agents 2018; 51: 163-4.

7 Chen L, Zhang J, Wang J et al. Newly identified colistin resistance genes, $m c r-4$ and $m c r-5$, from upper and lower alimentary tract of pigs and poultry in China. PLoS One 2018; 13: e0193957.

8 Zhang J, Chen L, Wang J et al. Molecular detection of colistin resistance genes (mcr-1 to $\mathrm{mcr}-5$ ) in human vaginal swabs. BMC Res Notes 2018; 11: 143.

9 Nordmann P, Jayol A, Poirel L. Rapid detection of polymyxin resistance in Enterobacteriaceae. Emerg Infect Dis 2016; 22: 1038-43.

10 Esposito F, Fernandes MR, Lopes R et al. Detection of colistin-resistant MCR-1-positive Escherichia coli by use of assays based on inhibition by EDTA and zeta potential. J Clin Microbiol 2017; 55: 3454-65.

11 Feng Y. Transferability of MCR-1/2 polymyxin resistance: complex dissemination and genetic mechanism. ACS Infect Dis 2018; 4: 291-300.

12 Liassine N, Assouvie L, Descombes MC et al. Very low prevalence of MCR$1 /$ MCR-2 plasmid-mediated colistin resistance in urinary tract Enterobacteriaceae in Switzerland. Int J Infect Dis 2016; 51: 4-5.

13 Matuschek E, Ähman J, Webster C et al. Antimicrobial susceptibility testing of colistin-evaluation of seven commercial MIC products against standard broth microdilution for Escherichia coli, Klebsiella pneumoniae, Pseudomonas aeruginosa, and Acinetobacter spp. Clin Microbiol Infect 2018; 24: 865-70. 


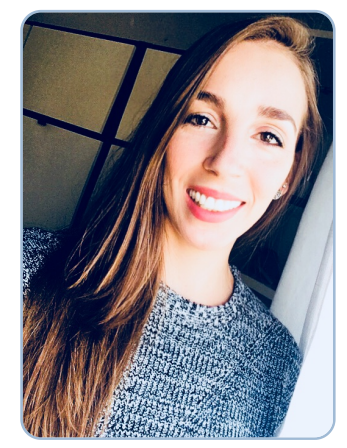

Miriam Rodriguez Fernandes

Endereço para acessar este CV: http://lattes.cnpq.br/1778042567979420

ID Lattes: $\mathbf{1 7 7 8 0 4 2 5 6 7 9 7 9 4 2 0}$

Última atualização do currículo em 16/04/2019

Bacharel em Biomedicina pelo Centro Universitário Lusíada (2009), Aprimoramento em Bacteriologia em Saúde Pública pelo Instituto Adolfo Lutz (2012) e Mestrado em Microbiologia ICB/USP (2015). Atualmente aluna de doutorado da FCF/USP. Possui experiência na área de Microbiologia, com ênfase em Bacteriologia Resistência Bacteriana, tendo como linha principal de pesquisa a caracterização de plasmídeos de resistência em bactérias com importância na medicina humana e veterinária. (Texto informado pelo autor)

\section{Identificação}

\begin{tabular}{ll}
\hline Nome & Miriam Rodriguez Fernandes \\
Nome em citações bibliográficas & FERNANDES,M.R; RODRIGUEZ-FERNANDES, MIRIAM;;FERNANDES, M. R.;FERNANDES, \\
& MIRIAM RODRIGUEZ;FERNANDES, M.R.;;ERNANDES, MIRIAM R.;FERNANDES, MIRIAM R \\
Lattes id & (9) http://lattes.cnpq.br/1778042567979420
\end{tabular}

Lattes iD

(9) http://lattes.cnpq.br/1778042567979420

\section{Endereço}

Endereço Profissional

Universidade de São Paulo, Instituto de Ciências Biomédicas.

Avenida Prof. Lineu Prestes, 1374

Cidade Universitária

05508900 - São Paulo, SP - Brasil

Telefone: (11) 958552657

\section{Formação acadêmica/titulação}

2015

$2013-2015$

$2010-2012$
Doutorado em andamento em Farmácia.

Universidade de São Paulo, USP, Brasil.

com período sanduíche em Istituto Superiori di Sanittà (Orientador: Alessandra Carattoli).

Título: Relação ancestral e pan-resistoma plasmidial de Escherichia coli produtora CTX-M-8 e MCR-1 na interface humana- animal- ambiental,

Orientador: (9) Nilton Erbet Lincopan Huenuman. Bolsista do(a): Fundação de Amparo à Pesquisa do Estado de São Paulo, FAPESP, Brasil. Mestrado em Microbiologia.

Universidade de São Paulo, USP, Brasil.

Título: A influência da antibióticoterapia na microbiota fecal de crianças em idade escolar,Ano de Obtenção: 2015.

Orientador: (9) Mario Julio Avila Campos.

Coorientador: Viviane Nakano.

Bolsista do(a): Coordenação de Aperfeiçoamento de Pessoal de Nível Superior, CAPES, Brasil.

Especialização em Bacteriologia em Saúde Pública. (Carga Horária: 3840h). Instituto Adolfo Lutz, IAL, Brasil.

Título: Investigação Epidemiológica Molecular de um surto de Doença Meningocócica em uma refinaria de petroleo e sua comunidade adjacente.

Orientador: Ana Paula Silva de Lemos.

Bolsista do(a): Fundação do Desenvolvimento Administrativo, FUNDAP, Brasil.

Graduação em Biomedicina.

Centro Universitário Lusíada, UNILUS, Brasil.

Título: O Clostridium difficile como agente indutor da colite pseudomembranosa..

Orientador: Carlos Somenzi. 


\begin{tabular}{|c|c|}
\hline $2019-2019$ & $\begin{array}{l}\text { Treinamento NGS- Painel Hereditary Cancer Solution - HCS. (Carga horária: 16h). } \\
\text { Sophia Genetics, SG, Suiça. }\end{array}$ \\
\hline 2019 - 2019 & $\begin{array}{l}\text { Nextera Flex DNA and Nextera Enrichment. (Carga horária: 12h). } \\
\text { Illumina, ILLUMINA, Brasil. }\end{array}$ \\
\hline $2019-2019$ & $\begin{array}{l}\text { NovaSeq operational training. (Carga horária: 20h). } \\
\text { Illumina, ILLUMINA, Brasil. }\end{array}$ \\
\hline 2017 - 2017 & $\begin{array}{l}\text { Extensão universitária em Genomics and Epidemiological Surveillance of Bacterial } \\
\text { Pathogens. (Carga horária: } 40 \mathrm{~h}) \text {. } \\
\text { Wellcome Genome Campus, WGC, Grã-Bretanha. }\end{array}$ \\
\hline $2014-2014$ & $\begin{array}{l}\text { Biologia Estrutural: no desenvolvimento de drogas. (Carga horária: 4h). } \\
\text { Universidade de São Paulo, USO, Brasil. }\end{array}$ \\
\hline $2014-2014$ & $\begin{array}{l}\text { "Resistência Bacteriana: clínica-laboratório. (Carga horária: 8h). } \\
\text { Universidade Federal de São Paulo, UNIFESP, Brasil. }\end{array}$ \\
\hline $2014-2014$ & $\begin{array}{l}\text { Hospital-Acquired Infections/Antimicrobial Resist.. (Carga horária: 96h). } \\
\text { American Society For Microbiology, Estados Unidos. }\end{array}$ \\
\hline $2013-2013$ & $\begin{array}{l}\text { Mecanismos de ação dos antibióticos. (Carga horária: 4h). } \\
\text { Universidade de São Paulo, USO, Brasil. }\end{array}$ \\
\hline $2012-2012$ & $\begin{array}{l}\text { Citometria de Fluxo: Aplicações em Microbiologia. (Carga horária: 4h). } \\
\text { Instituto de Ciências Biomédicas, ICB, Brasil. }\end{array}$ \\
\hline $2012-2012$ & $\begin{array}{l}\text { Workshop: Da extração a PCR em Tempo Real. (Carga horária: 8h). } \\
\text { Life Technologies, LIFE, Brasil. }\end{array}$ \\
\hline $2011-2011$ & $\begin{array}{l}\text { Espectrometria de Massas e suas Aplicações. (Carga horária: 4h). } \\
\text { Instituto Adolfo Lutz, IAL, Brasil. }\end{array}$ \\
\hline $2011-2011$ & $\begin{array}{l}\text { Curso Básico de PCR em Tempo Real- Suas Aplicações. (Carga horária: 12h). } \\
\text { Instituto Adolfo Lutz, IAL, Brasil. }\end{array}$ \\
\hline $2011-2011$ & $\begin{array}{l}\text { Curso Teórico - Prático de PCR em Tempo Real. (Carga horária: 12h). } \\
\text { Lab Trade, LAB TRADE, Brasil. }\end{array}$ \\
\hline $2010-2010$ & $\begin{array}{l}\text { Curso de Biossegurança Laboratorial. (Carga horária: 20h). } \\
\text { Instituto Adolfo Lutz, IAL, Brasil. }\end{array}$ \\
\hline $2010-2010$ & $\begin{array}{l}\text { Estruturação de Artigo Científico. (Carga horária: 24h). } \\
\text { Instituto Adolfo Lutz, IAL, Brasil. }\end{array}$ \\
\hline $2010-2010$ & $\begin{array}{l}\text { Plano de Gerenciamento de Resíduos. (Carga horária: 3h). } \\
\text { Instituto Adolfo Lutz, IAL, Brasil. }\end{array}$ \\
\hline $2010-2010$ & $\begin{array}{l}\text { Fundamentos da Citometria de Fluxo. (Carga horária: 17h). } \\
\text { Universidade de São Paulo, USP, Brasil. }\end{array}$ \\
\hline $2010-2010$ & $\begin{array}{l}\text { Diretrizes gerais para Contenção com Microrganismo. (Carga horária: 3h). } \\
\text { Instituto Adolfo Lutz, IAL, Brasil. }\end{array}$ \\
\hline $2010-2010$ & $\begin{array}{l}\text { Uso de equipamento de proteção individual. (Carga horária: 2h). } \\
\text { Instituto Adolfo Lutz, IAL, Brasil. }\end{array}$ \\
\hline $2010-2010$ & $\begin{array}{l}\text { Técnicas de Diagnóstico Molecular. (Carga horária: 76h). } \\
\text { Instituto Centro de Genomas, ICG, Brasil. }\end{array}$ \\
\hline $2010-2010$ & $\begin{array}{l}\text { II Curso de Políticas Públicas. (Carga horária: 35h). } \\
\text { Instituto Adolfo Lutz, IAL, Brasil. }\end{array}$ \\
\hline $2009-2009$ & $\begin{array}{l}\text { Treinamento em Biossegurança. (Carga horária: 6h). } \\
\text { Universidade de São Paulo, USP, Brasil. }\end{array}$ \\
\hline $2009-2009$ & $\begin{array}{l}\text { Teórico e Prático de Microbiologia Alimentar. (Carga horária: 12h). } \\
\text { Centro Universitário Lusíada, UNILUS, Brasil. }\end{array}$ \\
\hline 2009 - 2009 & $\begin{array}{l}\text { Teórico e Prático de Antibiograma. (Carga horária: 12h). } \\
\text { Centro Universitário Lusíada, UNILUS, Brasil. }\end{array}$ \\
\hline $2008-2008$ & $\begin{array}{l}\text { Curso Teórico e Prático de Antibiograma. (Carga horária: 15h). } \\
\text { Centro Universitário Lusíada, UNILUS, Brasil. }\end{array}$ \\
\hline $2006-2006$ & $\begin{array}{l}\text { Bases Cel/Mol. das Transformações Malignas. (Carga horária: 16h). } \\
\text { Centro Universitário Lusíada, UNILUS, Brasil. }\end{array}$ \\
\hline $2006-2006$ & $\begin{array}{l}\text { Primeiros Socorros. (Carga horária: 8h). } \\
\text { Centro Universitário Lusíada, UNILUS, Brasil. }\end{array}$ \\
\hline
\end{tabular}

\section{Atuação Profissional}

Universidade de São Paulo, USP, Brasill.

Vínculo institucional

2013 - Atual

Vínculo institucional

2012 - 2013

Outras informações
Vínculo: Bolsista, Enquadramento Funcional: Aluna Mestrado, Regime: Dedicação exclusiva.

Vínculo: Bolsista, Enquadramento Funcional: Treinamento Técnico - TT3, Carga horária: 40, Regime: Dedicação exclusiva. 
Vínculo institucional

$2009-2010$

Outras informações
Expressão dos genes bmeABC de bombas de efluxo de Bacteroides fragilis em Escherichia coli, caracterização do perfil de substrato das bombas bmeABC e sua relação com a resistência aos antimicrobianos.

Vínculo: Aluna, Enquadramento Funcional: Estágio, Carga horária: 40 Estágio extracurricular em Bacteriologia de Anaeróbios. Identificações bacterianas, caracterizações fenotípicas e genotípicas de bactérias anaeróbias.

Instituto Adolfo Lutz, IAL, Brasil.

Vínculo institucional

$2010-2012$

Outras informações
Vínculo: Aprimoramento Profissional, Enquadramento Funcional: Bolsista, Carga horária: 40, Regime: Dedicação exclusiva.

Bacteriologia em Saúde Pública Caracterização fenotípica e genotípica de bactérias causadoras de Meningites, Pneumonias, Leptospirose, Difteria, Coqueluche , Micobacterioses, Doenças diarréicas e causadoras de Infecções Hospitalares.

Pronto Socorro Central de Santos, PSC, Brasil.

Vínculo institucional

$2009-2009$

Outras informações
Vínculo: Estágio, Enquadramento Funcional: Estágio, Carga horária: 8

Estágio voluntário em laboratório de emergência

\section{Centro Universitário Lusíada, UNILUS, Brasil.}

Vínculo institucional

2009 - 2009

Outras informações
Vínculo: Aluna, Enquadramento Funcional: Estágio Curricular, Carga horária: 30 Estágio obrigatório supervisionado em Análises Clínicas

\section{Projetos de pesquisa}

$2013-2015$

$2012-2014$

$2012-2013$
A influência da antibióticoterapia na microbiota fecal de crianças em idade escolar Situação: Concluído; Natureza: Pesquisa.

Alunos envolvidos: Mestrado acadêmico: (2) .

Integrantes: Miriam Rodriguez Fernandes - Integrante / Viviane Nakano - Coordenador / Aline Ignacio - Integrante / Mario Julio Avila-Campos - Integrante. Avaliação de alguns microrganismos da microbiota intestinal endógena de crianças eutróficas, obesas e com sobrepeso em idade escolar.

Situação: Concluído; Natureza: Pesquisa.

Alunos envolvidos: Mestrado acadêmico: (2) .

Integrantes: Miriam Rodriguez Fernandes - Integrante / Viviane Nakano - Coordenador / Aline Ignacio - Integrante.

Expressão dos genes bmeABC de bombas de efluxo de Bacteroides fragilis em Escherichia coli, caracterização do perfil de substrato das bombas BmeABC e sua relação com a resistência aos antimicrobianos

Situação: Concluído; Natureza: Pesquisa.

Integrantes: Miriam Rodriguez Fernandes - Integrante / Viviane Nakano - Coordenador. Investigação Epidemiológica Molecular de um surto de Doença Meningocócica em uma refinaria de petróleo e sua comunidade adjacente.

Situação: Concluído; Natureza: Pesquisa.

Integrantes: Miriam Rodriguez Fernandes - Integrante / Ana Paula Silva de Lemos Coordenador / Maria Cecília Gorla - Integrante.

\section{Revisor de periódico}




\section{Áreas de atuação}

\begin{tabular}{ll}
\hline 1. & Grande área: Ciências Biológicas / Área: Microbiologia / Subárea: Bacteriologia. \\
2. & Grande área: Ciências Biológicas / Área: Microbiologia / Subárea: Resistência bacteriana.
\end{tabular}

\section{Idiomas}

\begin{tabular}{ll}
\hline Inglês & Compreende Razoavelmente, Fala Razoavelmente, Lê Bem, Escreve Bem. \\
Espanhol & Compreende Bem, Fala Bem, Lê Bem, Escreve Bem.
\end{tabular}

\section{Prêmios e títulos}

\section{Produções}

\section{Artigos completos publicados em periódicos}

Ordenar por

Ordem Cronológica $\quad \nabla$

1. MONTE, DANIEL F. ; SELLERA, F. P. ; FERNANDES,M.R ; MOURA, QUÉZIA ; LANDGRAF, MARIZA ; LINCOPAN, NILTON . Genome Sequencing of an Escherichia coli Sequence Type 617 Strain Isolated from Beach Ghost Shrimp ( Callichirus $m$ ajor ) from a Heavily Polluted Ecosystem Reveals a Wider Resistome against Heavy Metals and Antibiotics. Microbiology Resource Announcements, v. 8, p. e01471-18, 2019.

2. SELLERA, FÁBIO P ; FERNANDES,M.R ; SABINO, CAETANO P. ; FREITAS, F. M. ; SILVA, L. C. B. A. ; POGLIANI, F. C. ; RIBEIRO, M. S. ; HAMBLIN, M. R. ; LINCOPAN, N. . Effective treatment and decolonization of a dog infected with carbapenemase (VIM-2)-producing Pseudomonas aeruginosa using probiotic and photodynamic therapies.. VETERINARY DERMATOLOGY JCR, V. XX, p. XX, 2019.

3. GOLDBERG, D. W. ; FERNANDES,M.R ; SELLERA, FÁBIO P ; COSTA, D. G. C. ; BRACARENSE, A. P. L. ; LINCOPAN, NILTON . Genetic background of CTX-M-15-producing Enterobacter hormaechei ST114 and Citrobacter freundii ST265 Coinfecting a free-living green turtle (Chelonia mydas). Zoonoses and Public Health JCR, v. XX, p. XX, 2019.

4. SACRAMENTO, A. G. ; FERnANDES, M. R. ; SELLERA, FÁBIO P ; DOLABELLA, S. S. ; ZANELLA, R. C. ; CERDEIRA, L. T. ; LINCOPAN, NILTON . VanA-type vancomycin-resistant Enterococcus faecium ST1336 isolated from mussels in an anthropogenically impacted ecosystem. MARINE POLLUTION BULLETIN JCR, v. 142, p. 533-536, 2019.

5. FUENTES-CASTILLO, D. ; FARFAN-LOPEZ, M. ; ESPOSITO, FERNANDA ; MOURA, QUÉZIA ; FERNANDES, M. R. ; LOPES, RALF ; CARDOSO, B. ; MUNOZ, M. E. ; CERDEIRA, LOUISE ; NAJLE, I. ; MUNOZ, P. M. ; CATAO-DIAS, J. L. ; GONZALEZACUNA, D. ; LINCOPAN, NILTON . Wild owls colonized by international clones of extended-spectrum $\beta$-lactamase (CTX-M)producing Escherichia coli and Salmonella Infantis in the Southern Cone of America. SCIENCE OF THE TOTAL ENVIRONMENT JCR, v. XX, p. XX, 2019.

6. SELLERA, FÁBIO P. ; FERNANDES, MIRIAM R. ; SILVA, Q. M. ; SOUZA, TIAGO A. ; NASCIMENTO, C. L. ; CERDEIRA, LOUISE ; LINCOPAN, NILTON . Draft genome sequence of an extensively drug-resistant Pseudomonas aeruginosa isolate belonging to ST644 isolated from a footpad infection in a Magellanic penguin ( Spheniscus magellanicus ).. Journal of Global Antimicrobial Resistance JCR, v. 12, p. 88-89, 2018.

7. FERNANDES, MIRIAM R.; SELLERA, FÁBIO P. ; SILVA, Q. M. ; SOUZA, TIAGO A. ; LINCOPAN, NILTON . Draft Genome Sequence of a CTX-M-8, CTX-M-55 and FosA3 Co-producing Escherichia coli ST117/B2 Isolated from an Asymptomatic Carrier.. Journal of Global Antimicrobial Resistance JCR , v. 12, p. 183-184, 2018.

8. ARAUJO, B. F. ; FERREIRA, M. L. ; CAMPOS, P. A. ; ROYER, S. ; GONCALVES, I. R. ; BATISTAO, D. W. F. ; FERNANDES, MIRIAM R. ; CERDEIRA, LOUISE ; BRITO, C. S. ; LINCOPAN, NILTON ; GONTIJO-FILLHO, P. P. ; RIBAS, R. M. . Hypervirulence and biofilm production in KPC-2-producing Klebsiella pneumoniae CG258 isolated in Brazil.. JOURNAL OF MEDICAL MICROBIOLOGY JCR, v. 67, p. 523-528, 2018. 
SILVA, Q. M. ; CERDEIRA, LOUISE ; FERNANDES, MIRIAM R. ; VIANELLO, M. A. ; LINCOPAN, NILTON . Novel class 1 integron (In1390) harboring blaGES-5 in a Morganella morganii strain recovered from a remote community.. DIAGNOSTIC MICROBIOLOGY AND INFECTIOUS DISEASE JCR, v. S0732-8893, p. 30084-1, 2018.

10.

TAMARIZ, JESUS ; LLANOS, CARLOS ; SEAS, CARLOS ; MONTENEGRO, PAOLA ; LAGOS, JOSE ; FERNANDES, MIRIAM R. ; CERDEIRA, LOUISE ; LINCOPAN, NILTON . Draft Genome Sequence of the First New Delhi Metallo- $\beta$ Lactamase (NDM-1)-Producing Escherichia coli Strain Isolated in Peru. GENOME ANNOUNCEMENTS, v. 6, p. e00199-18, 2018.

11.

12.

13.

FERNANDES, MIRIAM R.; SELLERA, FÁBIO P. ; MOURA, QUÉZIA ; CARVALHO, MARCELO P.N. ; ROSATO, PAULA N. ; CERDEIRA, LOUISE ; LINCOPAN, NILTON . Zooanthroponotic Transmission of Drug-Resistant Pseudomonas aeruginosa , Brazil. EMERGING INFECTIOUS DISEASES JCR, v. 24, p. 1160-1162, 2018.

SELLERA, FÁBIO P ; FERNANDES, MIRIAM R ; RUIZ, REGINA ; FALLEIROS, ANA C M ; RODRIGUES, FERNANDA P ; CERDEIRA, LOUISE ; LINCOPAN, NILTON . Identification of KPC-2-producing Escherichia coli in a companion animal: a new challenge for veterinary clinicians. JOURNAL OF ANTIMICROBIAL CHEMOTHERAPY JCR, v. 73, p. 2259-2261, 2018.

13. SELLERA, FÁBIO P. ; FERNANDES, MIRIAM R. ; MOURA, QUÉZIA ; LOPES, RALF B. ; SOUZA, TIAGO A. ; CERDEIRA, LOUISE ; LINCOPAN, NILTON . Draft genome sequence of a bla CMY-2 /IncI1-harbouring Escherichia coli D:ST457 isolated from coastal benthic organisms. Journal of Global Antimicrobial Resistance JCR, v. 14, p. 83-84, 2018.

14.

SILVA, MEIRE M. ; FERNANDES, MIRIAM R. ; SELLERA, FÁBIO P. ; CERDEIRA, LOUISE ; MEDEIROS, LYLIAN K.G. ; GARINO, FELÍCIO ; AZEVEDO, SÉRGIO S. ; LINCOPAN, NILTON . Multidrug-resistant CTX-M-15-producing Klebsiella pneumoniae ST231 associated with infection and persistent colonization of dog. DIAGNOSTIC MICROBIOLOGY AND INFECTIOUS DISEASE JCR, v. S0732-, p. 30211-6, 2018.

15.

SELLERA, FÁBIO P. ; FERNANDES, MIRIAM R. ; MOURA, QUÉZIA ; CARVALHO, MARCELO P.N. ; LINCOPAN, NILTON . Extended-spectrum- $\beta$-lactamase (CTX-M)-producing Escherichia coli in wild fishes from a polluted area in the Atlantic Coast of South America. MARINE POLLUTION BULLETIN JCR, v. 135, p. 183-186, 2018.

16. OliveirA, F. A. ; ZACCARIOTTO, T.R ; PIVETA, C. ; HOFLING, C. C. ; RESENDE, M. R. ; LEVY, C. E. ; ESPOSITO, F. ; FERNANDES, M. R. ; CERDEIRA, LOUISE ; LINCOPAN, NILTON . MCR-1-positive colistin-resistant Escherichia coli in immunocompromised hospitalised patients.. INTERNATIONAL JOURNAL OF ANTIMICROBIAL AGENTS JCR, v. S0924-8579, p. 30178, 2018.

17.

FERNANDES, MIRIAM R; CERDEIRA, LOUISE ; SILVA, MEIRE M ; SELLERA, FÁBIO P ; MUÑOZ, MARIA ; JUNIOR, FELICIO G ; AZEVEDO, SERGIO S ; POWER, PABLO ; GUTKIND, GABRIEL ; LINCOPAN, NILTON . Novel mcr-5.3 variant in a CTX-M-8-producing Escherichia coli ST711 isolated from an infected horse. JOURNAL OF ANTIMICROBIAL CHEMOTHERAPY JCR, V. 00, p. XX, 2018.

18. ARAÚJO, BRUNA FUGA ; ROYER, SABRINA ; CAMPOS, PAOLA AMARAL ; FERREIRA, MELINA LORRAINE ; GONÇALVES, IARA ROSSI ; MACHADO, LUIZ GUSTAVO ; LINCOPAN, NILTON ; FERNANDES, MIRIAM RODRIGUEZ ; CERDEIRA, LOUISE TEIXEIRA ; BATISTÃO, DEIVID WILLIAM DA FONSECA ; GONTIJO-FILHO, PAULO P. ; RIBAS, ROSINEIDE MARQUES . Insights into a novel Tn4401 deletion (Tn4401i) in multidrug-resistant Klebsiella pneumoniae clinical strain belonging to the high-risk Clonal Group 258 producing KPC-2. INTERNATIONAL JOURNAL OF ANTIMICROBIAL AGENTS JCR, v. 18, p. 30237-1, 2018.

19. FERNANDES, MIRIAM R.; SELLERA, FÁBIO P. ; MOURA, QUÉZIA ; GASPAR, VITOR C. ; CERDEIRA, LOUISE ; LINCOPAN, NILTON . International high-risk clonal lineages of CTX-M-producing Escherichia coli F-ST648 in free-roaming cats, South America. INFECTION GENETICS AND EVOLUTION ICR, v. XX, p. XX, 2018.

20.

SILVA, MEIRE M. ; SELLERA, FÁBIO P. ; FERNANDES, MIRIAM R. ; MOURA, QUÉZIA ; GARINO, FELÍCIO ; AZEVEDO, SÉRGIO S. ; LINCOPAN, NILTON . Genomic features of a highly virulent ceftiofur-resistant CTX-M-8-producing Escherichia coli ST224 causing fatal infection in a domestic cat. Journal of Global Antimicrobial Resistance JCR, v. 00, p. XX$\mathrm{xx}, 2018$.

21. SACRAMENTO, A. G. ; FERNANDES,M.R ; SELLERA, F. P. ; MUNOZ, M. E. ; VIVAS, R. ; DOLABELLA, S. S. ; LINCOPAN, NILTON . Genomic analysis of MCR-1 and CTX-M-8 co-producing Escherichia coli ST58 isolated from a polluted mangrove ecosystem in Brazil.. Journal of Global Antimicrobial Resistance JCR, v. 00, p. XX, 2018.

22. ESPINAL, P. ; NUCLEO, E. ; CALTAGIRONE, M. ; MARCHETTI, V. M. ; FERNANDES, M.R ; BISCARO, V. ; RIGOLI, R. ; CARATTOLI, A. ; MIGLIAVACCA, R. ; VILLA, L. . Genomics of Klebsiella pneumoniae ST16 producing NDM-1, CTX-M-15, and OXA-232.. CLINICAL MICROBIOLOGY AND INFECTION JCR, v. 22, p. S1198-743X(18)3, 2018.

23. CARVALHO, MARCELO P.N. ; SILVA, Q. M. ; FERNANDES,M.R ; SELLERA, FÁBIO P ; PAGOTTO, A. H. ; STUGINSKI, D. R. ; CASTRO, R. A. ; SANTANNA, S. S. ; GREGO, K. F. ; LINCOPAN, NILTON. Genomic features of a multidrug-resistant Enterobacter cloacae ST279 producing CTX-M-15 and AAC(6')-Ib-cr isolated from fatal infectious stomatitis in a crossed pit viper (Bothrops alternatus).. Journal of Global Antimicrobial Resistance JCR, v. 15, p. 290-291, 2018.

24. SELLERA, F. P. ; FERNANDES, M. R. ; SARTORI, L. ; CARVALHO, M. P. N. ; NASCIMENTO, C. L. ; DUTRA, G. H. P. ; MAMIZUKA, E. M. ; PEREZ-CHAPARRO, P. J. ; MCCULLOCH, J. A. ; LINCOPAN, N. . Escherichia coli carrying IncX4 plasmidmediated mcr-1 and blaCTX-M genes in migratory Magellanic penguins (Spheniscus magellanicus). JOURNAL OF ANTIMICROBIAL CHEMOTHERAPY (ONLINE) JCR, v. 72, p. 1255-1256, 2017.

25. CERDEIRA, L. T. ; FERNANDES,M.R ; IENNE, S. ; SOUZA, T. A. ; GARCIA, D. O. ; LINCOPAN, N. . Draft genome sequence of an environmental multidrug-resistant Klebsiella pneumoniae ST340/CC258 harbouring blaCTX-M-15 and blaKPC-2 genes. Journal of Global Antimicrobial Resistance JCR , v. 8, p. 108-109, 2017.

26. MONTE, D. F. ; MEM, A. ; FERNANDES,M.R ; CERDEIRA, L. T. ; ESPOSITO, F. ; GALVAO, J. A. ; FRANCO, B. ; LINCOPAN, N. ; LANDGRAF, M. . Chicken Meat as Reservoir of Colistin-Resistant Escherichia coli Carrying mcr-1 Genes in South America. ANTIMICROBIAL AGENTS AND CHEMOTHERAPY (ONLINE) JCR, v. 61, p. e02718-16, 2017.

27. SILVA, Q. M. ; FERNANDES, M.R. ; SILVA, K. C. ; MONTE, D. F. ; ESPOSITO, F. ; DROPA, M. ; NORONHA, C. ; MORENO, A. M. ; LANDGRAF, M. ; NEGRAO, J. A. ; LINCOPAN, N. . Virulent nontyphoidal Salmonella producing CTX-M and CMY-2 $\beta$ - 
lactamases from livestock, food and human infection, Brazil. Virulence JCR, v. 1, p. 1-6, 2017.

28. NASCIMENTO, T. ; CANTAMESSA, R. ; MELO, L. C. ; FERNANDES,M.R ; FRAGA, E. ; DROPA, M. ; SATO, M. I. Z. ; CERDEIRA, L. T. ; LINCOPAN, N. . International high-risk clones of Klebsiella pneumoniae KPC-2/CC258 and Escherichia coli CTX-M-15/CC10 in urban lake waters.. SCIENCE OF THE TOTAL ENVIRONMENT JCR, v. 598, p. 910-915, 2017.

Citações: WEB OF SCIENCE 2 | SCOPUS 2

29. Silva, Q. M. ; Fernandes, M. R. ; CERDEIRA, L. T. ; MELO, A. C. ; SOUZA, T. A. ; IENNE, S. ; PIGNATARI, A. C. ; GALES, A. C. ; SILVA, R. M. ; LINCOPAN, N. . Draft genome sequence of MDR Aeromonas hydrophila ST508 carrying rmtD and blaCTX-M-131 genes isolated from bloodstream infection. Journal of Global Antimicrobial Resistance JCR, v. 10, p. 289290, 2017.

30. FERNANDES, MIRIAM R.; SELLERA, FÁBIO P. ; ESPOSITO, FERNANDA ; SABINO, CAETANO P. ; CERDEIRA, LOUISE ; LINCOPAN, NILTON . Colistin-Resistant mcr-1 -Positive Escherichia coli in Public Beaches, an Infectious Threat Emerging in Recreational Waters. ANTIMICROBIAL AGENTS AND CHEMOTHERAPY JCR , v. 61, p. AAC.00234-17, 2017.

31.

MONTE, DANIEL F. ; FERNANDES, MIRIAM R. ; CERDEIRA, LOUISE ; DE SOUZA, TIAGO A. ; MEM, ANDRESSA ; FRANCO, BERNADETTE D. G. M. ; LANDGRAF, MARIZA ; LINCOPAN, NILTON . Draft Genome Sequences of ColistinResistant MCR-1-Producing Escherichia coliST1850 and ST74 Strains Isolated from Commercial Chicken Meat. GENOME ANNOUNCEMENTS, v. 5, p. e00329-17, 2017.

32. $\quad$ LOPES, RALF ; CERDEIRA, LOUISE T. ; FERNANDES, MIRIAM R. ; PÉREZ-CHAPARRO, PAULA J. ; MCCULLOCH, JOHN A. ; LINCOPAN, NILTON . Draft genome sequence of a CTX-M-15-producing endophytic Klebsiella pneumoniae ST198 isolate from commercial lettuce. Journal of Global Antimicrobial Resistance JCR, v. 10, p. 19-20, 2017.

33. ESPOSITO, F. ; FERNANDES, M. R. ; LOPES, R. ; MUNOZ, M. ; SABINO, C. P. ; CUNHA, M. P. ; SILVA, K. C. ; CAYO, R. ; MARTINS, W. M. ; MORENO, A. M. ; KNOBL, T. ; GALES, A. C. ; LINCOPAN, NILTON . Detection of Colistin-Resistant MCR-1Positive Escherichia coli Using Inhibition by EDTA and Zeta Potential Assays. JOURNAL OF CLINICAL MICROBIOLOGY JCR, V. JCM.00835-, p. 00, 2017.

34. SELLERA, FÁBIO P. ; FERNANDES, M. R. ; SILVA, Q. M. ; SOUZA, TIAGO A. ; CERDEIRA, LOUISE ; LINCOPAN, NILTON . Draft genome sequence of Enterobacter cloacae ST520 harbouring blaKPC-2, blaCTX-M-15 and blaOXA-17 isolated from coastal waters of the South Atlantic Ocean.. Journal of Global Antimicrobial Resistance JCR, v. 10, p. 279-280, 2017.

35. SILVA, Q. M. ; FERNANDES, M. R. ; CERDEIRA, LOUISE ; NHAMBE, L. ; IENNE, S. ; SOUZA, TIAGO A. ; LINCOPAN, NILTON . Draft genome sequence of a multidrug-resistant KPC-2-producing Enterobacter aerogenes isolated from a hospitalised patient in Brazil.. Journal of Global Antimicrobial Resistance JCR, v. 10, p. 277-278, 2017.

36.

SARTORI, LUCIANA ; FERNANDES, MIRIAM R. ; IENNE, SUSAN ; DE SOUZA, TIAGO A. ; GREGORY, LILIAN ; CERDEIRA, LOUISE ; LINCOPAN, NILTON . Draft genome sequences of two fluoroquinolone-resistant CTX-M-15-producing Escherichia coli ST90 (ST23 complex) isolated from calve and dairy cow in South America. Journal of Global Antimicrobial Resistance JCR, v. 11, p. 145-147, 2017.

37. SILVA, Q. M. ; ESPOSITO, F. ; FERNANDES, MIRIAM R. ; MUNOZ, M. E. ; SOUZA, TIAGO A. ; SANTOS, S. R. ; CERDEIRA, LOUISE ; CASSETTARI, V. ; LINCOPAN, N. . Genome sequence analysis of a hypermucoviscous/hypervirulent and MDR CTX-M-15/K19/ST29 Klebsiella pneumoniae isolated from human infection. Pathogens and Disease JCR, v. 75, p. XX, 2017.

38. CASELLA, TIAGO ; CERDEIRA, LOUISE T. ; FERNANDES, MIRIAM R. ; SOUZA, TIAGO A. ; HAENNI, MARISA ; MADEC, JEAN-YVES ; LINCOPAN, NILTON ; NOGUEIRA, MARA C.L. . Draft genome sequence of a CTX-M-15-producing Escherichia coli ST345 from commercial chicken meat in Brazil. Journal of Global Antimicrobial Resistance JCR, v. 9, p. 124125, 2017.

39. DROPA, M. ; LINCOPAN, N. ; BALSALOBRE, L. C. ; OLIVEIRA, D. E. ; MOURA, R. A. ; FERNANDES,M.R ; SILVA, Q. M. ; MATTE, G. R. ; SATO, M. I. Z. ; MATTE, M. H. . Genetic background of novel sequence types of CTX-M-8- and CTX-M-15producing Escherichia coli and Klebsiella pneumoniae from public wastewater treatment plants in São Paulo, Brazil. Environmental Science and Pollution Research International JCR, v. 23, p. p. 4953-4958, 2016.

Citações: WEB OF SCIENCE" 3 | SCOPUS 2

40. FERNANDES, M.R.; SILVA, Q. M. ; SARTORI, L. ; SILVA, K. C. ; CUNHA, M. P. ; ESPOSITO, F. ; LOPES, R. ; OTUTUMI, L. K. ; GONCALVES, D. D. ; DROPA, M. ; MATTE, M. H. ; MONTE, D. F. ; LANDGRAF, M. ; FRANCISCO, G. R. ; BUENO, M. F. ; GARCIA, D. O. ; KNOBL, T. ; MORENO, A. M. ; LINCOPAN, N. . Silent dissemination of colistin-resistant Escherichia coli in South America could contribute to the global spread of the mcr-1 gene. Eurosurveillance JCR, v. 21, p. p. 30214, 2016.

\section{Citações: SCOPUS 1}

41. FERNANDES,M.R; SILVA, Q. M. ; ESPOSITO, F. ; LINCOPAN, N. . Authors' reply: Escherichia coli harbouring mcr-1 gene isolated from poultry not exposed to polymyxins in Brazil.. Eurosurveillance JCR, v. 21, p. pii=30268, 2016.

\section{Citações: Scopus 1}

42. FERNANDES, M. R.; IGNACIO, A. ; RODRIGUES, V.A.A. ; GROPPO, F.C. ; CARDOSO, A. L. ; AVILA-CAMPOS, M.J. ; NAKANO, V. . Alterations of Intestinal Microbiome by Antibiotic Therapy in Hospitalized Children. Microbial Drug Resistance JCR, V. XX, P. XX, 2016.

43. FERNANDES, M. R.; MCCULLOCH, J. A. ; VIANELLO, M. A. ; SILVA, Q. M. ; PEREZ-CHAPARRO, P. J. ; ESPOSITO, F. ; SARTORI, L. ; DROPA, M. ; MATTE, M. H. ; LIRA, D. P. A. ; MAMIZUKA, E. M. ; LINCOPAN, N. . First Report of the Globally Disseminated IncX4 Plasmid Carrying the Gene in a Colistin-Resistant ST101 isolated from a Human Infection in Brazil.. Antimicrobial Agents and Chemotherapy (Print) JCR, v. 60, p. 6415-6417, 2016.

Citações: WEB OF SCIENCE 2 | SCOPUS 29

44. CERDEIRA, L. T. ; SILVA, K. C. ; FERNANDES, M. R. ; IENNE, S. ; SOUZA, T. A. ; GARCIA, D. O. ; MORENO, A. M. ; LINCOPAN, N. . Draft genome sequence of a CTX-M-15-producing Klebsiella pneumoniae sequence type 340 (clonal complex 258) isolate from a food-producing animal.. Journal of Global Antimicrobial Resistance JCR, v. 7, p. 67-68, 2016. 

Genome of a Hospital-Associated Clone of Klebsiella pneumoniae ST340/CC258 Co-Producing RmtG and KPC-2 Isolated from a Pediatric Patient. Genome Announcements, v. 4, p. e01130-16, 2016.

46. SILVA, Q. M. ; FERNANDES,M.R ; CERDEIRA, L. T. ; IENNE, S. ; SOUZA, T. A. ; NEGRAO, J. A. ; LINCOPAN, N. . Draft genome sequence of a multidrug-resistant CMY-2-producing Salmonella entérica subsp entérica serovar Minnesota ST3088 isolated from chicken meat. Journal of Global Antimicrobial Resistance JCR, v. 8, p. 67-69, 2016.

47. FUKUGAITI, M. H. ; IGNACIO, A. ; FERNANDES, M. R. ; RIBEIRO JUNIOR, U. ; NAKANO, V. ; AVILA-CAMPOS, M. J. . High occurrence of Fusobacterium nucleatum and Clostridium difficile in the intestinal microbiota of colorectal carcinoma patients. Brazilian Journal of Microbiology (Online) ICR, v. 4, p. 1135-1140, 2015.

Citações: WEB OF SCIENCE 2 | SCCPUS 7

48. IGNACIO, A. ; FERNANDES, MIRIAM RODRIGUEZ ; AVILA-CAMPOS, M. J. ; NAKANO, V. . Enterotoxigenic and nonenterotoxigenic Bacteroides fragilis from fecal microbiota of children.. Brazilian Journal of Microbiology (Online) JCR, v. 4, p. $1141-1145,2015$.

49. IGNACIO, A. ; FERNANDES, M.R. ; RODRIGUES, V.A.A. ; GROPPO, F.C. ; CARDOSO, A.L. ; AVILA-CAMPOS, M.J. ; NAKANO, V. . Correlation between body mass index and fecal microbiota from children. Clinical Microbiology and Infection (Print) JCR, v. 10, p. S1198-743X, 2015.

Citações: WEB OF SCIENCE $=2$ | SCOPUS 2

50. FERNANDES, M. R.; IGNACIO, A. ; MARTINS, F. H. ; ROCHA, L. B. ; PIAZZA, R. M. F. ; VAZ, T. M. I. ; AVILACAMPOS, M. J. ; NAKANO, V. . Presence of Shiga toxin 2e-producing Escherichia coli and atypical enteropathogenic E. coli in an asymptomatic child. JMM Case Reports, v. 1, p. e000001-e000001, 2014.

51.

LIPHAUS, BERNADETE L. ; CAPPELETTI-GONÇALVES-OKAI, MARIA INÊS ; SILVA-DELEMOS, ANA PAULA ; GORLA, MARIA CECÍLIA ; RODRIGUEZ-FERNANDES, MIRIAM ; PACOLA, MÁRCIA REGINA ; FERNANDEZ-COLLUCCI, MARIA ÂNGELA ; MATSUMOTO-SHINKAI, IARA AKEMI ; TAKENORI-HIGA, FÁBIO ; FERREIRA-CATANI, CLEIDE ; GONÇALVESLEMES-MARQUES, ENEIDA ; MARQUES-PINTO-CARVALHANAS, TELMA REGINA . Outbreak of Neisseria meningitidis C in a Brazilian oil refinery involving an adjacent community. Enfermedades Infecciosas y Microbiología Clínica (Ed. impresa) JCR, v. 31, p. 88-92, 2013.

Citações: WEB OF SCIENCE" 2 | SCOPUS 5

52. NAKANO, V. ; IGNACIO, A. ; FERNANDES,M.R ; FUKUGAITI, M. H. ; AVILA-CAMPOS, M. J. . Intestinal Bacteroides and Parabacteroides species producing antagonistic substances.. Current Trends in Microbiology, v. 8, p. 61-64, 2012.

Citações: scopus 1

\section{Textos em jornais de notícias/revistas}

1. FERNANDES, M. R.; LINCOPAN, N. . Encontrada no Brasil bactéria resistente a um dos mais poderosos antibióticos. Agência FAPESP, 12 ago. 2016.

\section{Trabalhos completos publicados em anais de congressos}

1. IGNACIO, A. ; FERNANDES,M.R ; RODRIGUES, V. A. A. ; GROPPO, F. C. ; CARDOSO, A. L. ; AVILA-CAMPOS, M. J. ; NAKANO, V. . Differences in anaerobe gut microbiota associated with weight gain in children. In: XXII Congreso Latinoamericano de Microbiología Y 4 Congresso Colombiano de Microbiología, 2014, Cartagena. Congreso Latinoamericano de Microbiología, 2014.

\section{Resumos publicados em anais de congressos}

1. MUNOZ, M. E. ; SILVA, Q. M. ; FERNANDES,M.R ; BUERIS, V. ; MELO, L. ; SELLERA, FÁBIO P. ; LOPES, RALF ; CERDEIRA, LOUISE ; SARTORI, LUCIANA ; MONTE, D. F. ; LANDGRAF, MARIZA ; LINCOPAN, N. . Resistencia a compuestos de amonios cuartenários (qac) em bactérias de importância médica em la interface humana- ambiente-animal: um desafio para os laboratórios de microbiologia clínica. In: XXIV Congresso Latino-Americano de Microbiologia, 2018, Santiago, Chile. XXIV Congresso Latino-Americano de Microbiologia, 2018.

2. ESPOSITO, F. ; BUERIS, V. ; COUTO, S. C. F. ; FERNANDES,M.R ; CERDEIRA, LOUISE ; LINCOPAN, N. . Efecto sinergico de antimicrobianos y soluciones hipertonicas de solución salinas contra biofimes produzidos por clones hospitalares alto riesgo del grupo ESKAPE. In: XXIV Congresso Latino-Americano de Microbiologia, 2018, Santiago, Chile. XXIV Congresso Latino-Americano de Microbiologia, 2018.

3. BARBOSA, B. ; ESPOSITO, FERNANDA ; CERDEIRA, LOUISE ; FERNANDES,M.R ; SILVA, Q. M. ; SARTORI, L. ; MELO, L. ; SELLERA, FÁBIO P ; MONTE, D. F. ; LOPES, RALF ; LINCOPAN, NILTON . . Analysis of mutation in the quinolone resistance determining region (QRDR) in $\mathrm{K}$. pneumoniae and $\mathrm{E}$. coli isolates from human- animal-environmental interface.. In: XXIV Congresso Latino-Americano de Microbiologia, 2018, Santiago, Chile. XXIV Congresso Latino-Americano de Microbiologia, 2018.

4. $\quad$ FERNANDES, M. R.; CERDEIRA, L. T. ; SELLERA, F. P. ; MONTE, D. F. ; SILVA, K. C. ; PEREZ-CHAPARRO, P. J. ; MCCULLOCH, J. A. ; LINCOPAN, N. . InCX4 plasmids are key vectors responsible for the dissemination of the mcr-1 gene among Escherichia coli from humans, animals, food and environment in Brazil. In: ASM Microbe, 2017, New Orleans. IncX4 plasmids are key vectors responsible for the dissemination of the mcr-1 gene among Escherichia coli from humans, animals, food and environment in Brazil, 2017.

5. CERDEIRA, L. T. ; FERNANDES, M. R. ; RODRIGUES, G. F. ; BUENO, M. F. ; LOPES, R. ; ESPOSITO, F. ; GARCIA, D. O. ; LINCOPAN, N. . Genomic Analysis of KPC-2/CTX-M-15-producing Klebsiella pneumoniae CC258 (ST340, ST11 and ST437) from Human, Animal and Aquatic Environment, Brazil. In: ASM Microbe, 2017, New Orleans. Genomic Analysis of KPC2/CTX-M-15-producing Klebsiella pneumoniae CC258 (ST340, ST11 and ST437) from Human, Animal and Aquatic Environment, Brazil, 2017. 

CERDEIRA, L. T. ; LINCOPAN, N. . MCR-1-,KPC-2-, and CTX-M- producing Enterobacteriaceae in marine ecosystem: an. In: 29 Congresso Brasileiro de Microbiologia, 2017, Foz do Iguaçu. 29 Congresso Brasileiro de Microbiologia, 2017. FERNANDES, M. R.; CERDEIRA, L. T. ; SELLERA, F. P. ; CUNHA, M. P. ; MONTE, D. F. ; SILVA, K. C. ; PEREZ-CHAPARRO, P. J. ; MCCULLOCH, J. A. ; LINCOPAN, N. . Nationwide ubiquity of IncX4 plasmids carrying the colistin resistance gene MCR1 in Enterobacteriaceae in Brazil. In: 29 Congresso Brasileiro de Microbiologia, 2017, Foz do Iguaçu. 29 Congresso Brasileiro de Microbiologia, 2017.

8. $\quad$ ESPOSITO, F. ; FERNANDES, M. R. ; LOPES, R. ; MUNOZ, M. E. ; SABINO, C. P. ; CUNHA, M. P. ; CAYO, R. ; MARTINS, W. M. ; GALES, A. C. ; LINCOPAN, N. . Simple and inexpensive methods for routine detection of colistin-resistant MCR-1 positive Escherichia coli in human and veterinary diagnostic laboratories. In: 29 Congresso Brasileiro de Microbiologia, 2017, Foz do Iguaçu. 29 Congresso Brasileiro de Microbiologia, 2017.

9. LOPES, R. ; FERNANDES, M. R. ; LINCOPAN, N. . Endophytic properties of colistin-resistant MCR-1-positive Escherichia coli. In: 29 Congresso Brasileiro de Microbiologia, 2017. 29 Congresso Brasileiro de Microbiologia, 2017.

10. CERDEIRA, L. T. ; FERNANDES, M. R. ; ESPOSITO, F. ; LOPES, R. ; RODRIGUES, G. F. ; BUENO, M. F. ; GARCIA, D. O. ; LINCOPAN, NILTON . Successful dissemination of Klebsiella pneumoniae CC258 (ST11,ST437,ST340) in Brazil is supported by AMR genes, ubiquity, plasmid stability and virulent behavior. In: 29 Congresso Brasileiro de Microbiologia, 2017. 29 Congresso Brasileiro de Microbiologia, 2017.

11. SA, K. R. ; MIRANDA, J. C. ; FERNANDES, M. R. ; MUNOZ, M. E. ; CERDEIRA, L. T. ; LINCOPAN, N. ; OLIVEIRA, C. J. B. ; SANTOS-FILHO, L. . Co-occurrence of blaKPC-2 and fosA genes in Enterobacter cloacae isolated from an urban river in Paraiba, Brazil. In: 29 Congresso Brasileiro de Microbiologia, 2017, Foz do Iguaçu. 29 Congresso Brasileiro de Microbiologia, 2017.

12. VASCONCELOS, P. C. ; MOREIRA-FILHO, A. I. ; FERNANDES, M. R. ; MUNOZ, M. E. ; LINCOPAN, N. ; OLIVEIRA, C. J. B. ; SANTOS-FILHO, L. . First detection of plasmid MCR-1 colistin resistance gene in extend-spectrum B-lactamase-producing Escherichia coli in chickean meat in Paraiba state, Brazil. In: 29 Congresso Brasileiro de Microbiologia, 2017. 29 Congresso Brasileiro de Microbiologia, 2017.

13. LOPES, R. ; CERDEIRA, L. T. ; FERNANDES, M. R. ; LINCOPAN, N. . Endophytic lifestyle of clinically significant CTX-M-15 producing Enterobacteriaceae uses commercial vegetables like trojan horse. In: 29 Congresso Brasileiro de Microbiologia, 2017, Foz do Iguaçu. 29 Congresso Brasileiro de Microbiologia, 2017.

14. ALMEIDA, L. M. ; LEBRETON, F. ; BISPO, P. ; SAAVEDRA, J. T. ; WUSTER, J. ; PIRES, C. ; FERNANDES,M.R ; CERDEIRA, L. T. ; LINCOPAN, N. ; MORENO, A. M. ; MAMIZUKA, E. M. ; GILMORE, M. S. . Transferable Resistance Gene optrA in Enterococcus faecalis isolated from swine in Brazil. In: ICAAC Interscience Conference on. Antimicrobial Agents and Chemotherapy., 2016, Boston. ICAAC Interscience Conference on. Antimicrobial Agents and Chemotherapy., 2016.

15. VIANELlO, M. A. ; SOBREIRA, A. M. ; APPOLINARIO, E. V. ; LIRA, D. P. A. ; SILVA, Q. M. ; FERNANDES,M.R ; LINCOPAN N. ; ROMAO, A. B. D. ; RIBEIRO, M. D. ; SANTOS, C. G. M. . Serratia marcescens produtora de carbapenemase em ITU de repetiçao em lactente: Importancia do correto diagnóstico clínico e microbiológico. In: 43 Congresso Brasileiro de Análises Clínicas, 2016, Sao Paulo. 43 Congresso Brasileiro de Análises Clínicas, 2016.

16. VIANELLO, M. A. ; LIRA, D. P. A. ; LINCOPAN, N. ; FERNANDES,M.R ; SILVA, Q. M. ; ROMAO, A. B. D. ; RIBEIRO, M. D. ; SANTOS, C. G. M. . Abcesso epidural bacteremico em topografia medular por Klebsiella pneumoniae produtora de carbapenemase : importancia do correto diagnóstico clinico e microbiologico- Relato de Caso. In: 43 Congresso Brasileiro de Análises Clínicas, 2016, Sao Paulo. 43 Congresso Brasileiro de Análises Clínicas, 2016.

17. FERNANDES, M. R.; CARDOSO, N. S. ; SILVA, Q. M. ; SARTORI, L. ; ESPOSITO, F. ; SILVA, K. C. ; OTUTUMI, L. K. ; GONCALVES, D. D. ; CUNHA, M. P. ; DROPA, M. ; KNOBL, T. ; MATTE, M. H. ; MORENO, A. M. ; LINCOPAN, N. . Coproduction of MCR-1, CTX-M and CMY-2 Plasmid-Mediated b-Lactamases in Escherichia coli from food-producing animals in Brazil. In: XXIII Congresso Latinoamericano de Microbiologia, 2016, Rosário. Co-production of MCR-1, CTX-M and CMY-2 Plasmid-Mediated b-Lactamases in Escherichia coli from food-producing animals in Brazil, 2016.

18. FERNANDES, M. R.; CARDOSO, N. S. ; AVILA-CAMPOS, M. J. ; NAKANO, V. . Multidrug-resistant commensal E. coli isolated from children with and without antibiotic therapy. In: 28 Congresso Brasileiro de Microbiologia, 2015, Florianópolis. 28 Congresso Brasileiro de Microbiologia, 2015.

19. CARDOSO, N. S. ; FERNANDES,M.R ; BUERIS, V. ; SIRCILI, M. ; AVILA-CAMPOS, M. J. ; NAKANO, V. . Adherence pattern and cytotoxicity of commensal and diarrheagenic E. coli isolated of children without diarrhea. In: 28 Congresso Brasileiro de Microbiologia, 2015, Florianopolis. 28 Congresso Brasileiro de Microbiologia, 2015.

20. FERNANDES,M.R; IGNACIO, A. ; RODRIGUES, V. A. A. ; GROPPO, F. C. ; CARDOSO, A. L. ; AVILA-CAMPOS, M. J. ; NAKANO, V. . Análise comparativa e quantitativa de espécies de Bifidobacterium, Bacteroides e Clostridium em amostras fecais de crianças submetidos à antibioticoterapia.. In: XXII Congreso Latinoamericano de Microbiología Y 4 Congresso Colombiano de Microbiología, 2014, Cartagena. Congreso Latinoamericano de Microbiología, 2014.

21. FERNANDES,M.R; IGNACIO, A. ; GROPPO, F. C. ; CARDOSO, A. L. ; AVILA-CAMPOS, M. J. ; NAKANO, V. . Comparative analysis of the presence of Bifidobacterium spp. in children feed with breast milk and formula milk.. In: XXII Congreso Latinoamericano de Microbiología Y 4 Congresso Colombiano de Microbiología, 2014, Cartagena. Congreso Latinoamericano de Microbiología, 2014.

22. FERNANDES,M.R; IGNACIO, A. ; AVILA-CAMPOS, M. J. ; NAKANO, V. . Perfil de susceptibilidade aos antimicrobianos de Escherichia coli comensal e diarreiogênica isoladas de amostras fecais de crianças sem diarreia.. In: XXII Congreso Latinoamericano de Microbiología Y 4 Congresso Colombiano de Microbiología, 2014, Cartagena. Congreso Latinoamericano de Microbiología, 2014.

23. IGNACIO, A. ; FERNANDES,M.R ; AVILA-CAMPOS, M. J. ; NAKANO, V. . Detection of TpeL and NetB genes in Clostridium perfringens isolated from healthy children.. In: XXII Congreso Latinoamericano de Microbiología Y 4 Congresso Colombiano de Microbiología, 2014, Cartagena. Congreso Latinoamericano de Microbiología, 2014.

24. FERNANDES,M.R; IGNACIO, A. ; CARDOSO, A. L. ; AVILA-CAMPOS, M. J. ; NAKANO, V. . Influência da antibioticoterapia na microbiota intestinal endógena de crianças sem diarreia: análise preliminar. In: $27^{\circ}$ Congresso Brasileiro de Microbiologia, 2013, Natal. 270 Congresso Brasileiro de Microbiologia, 2013.

25. IGNACIO, A. ; FERNANDES,M.R ; PIAZZA, R. M. F. ; CARDOSO, A. L. ; AVILA-CAMPOS, M. J. ; NAKANO, V. . Presença da toxina Tpel em Clostridium perfrirgens de amostras fecais não diarreicas em crianças da cidade de São Paulo, Brasil. In: 270 Congresso Brasileiro de Microbiologia, 2013, Natal. 270 Congresso Brasileiro de Microbiologia, 2013. 

Aggregatibacter actinomycetemcomitans e Fusobacterium nucleatum em biofilme subgengival de pacientes com gengivite, periodontite crônica e sadios.. In: 270 Congresso Brasileiro de Microbiologia, 2013, Natal. 270 Congresso Brasileiro de Microbiologia, 2013.

27. IGNACIO, A. ; FERNANDES,M.R ; AVILA-CAMPOS, M. J. ; NAKANO, V. . Análise comparativa de estado nutricional e da microbiota intestinal endógena de crianças eutróficas, obesas e com sobrepeso na cidade de São Paulo: dados parciais.. In: XXI Congresso Latinoamericano de Microbiologia (XXI ALAM), 2012, Santos. XXI Congresso Latinoamericano de Microbiologia (XXI ALAM), 2012.

28. FERNANDES,M.R; IGNACIO, A. ; PIAZZA, R. M. F. ; NAKANO, V. . Avaliação de Escherichia coli diarreiogênica de crianças em idade escolar sem diarréia: dados preliminares. In: XXI Congresso Latinoamericano de Microbiologia (XXI ALAM), 2012, Santos. XXI Congresso Latinoamericano de Microbiologia (XXI ALAM), 2012.

\section{Apresentações de Trabalho}

1. FERNANDES,M.R. Resistencia antibiotica en alimentos y lineas de producicon de alimentos de origen animal. 2018. (Apresentação de Trabalho/Conferência ou palestra).

2. FERNANDES, M. R.; LINCOPAN, N. . Emergência do gene mcr-1 entre isolados de Escherichia coli de origem humana e veterinária mediada por plasmídeos IncX4 mundialmente disseminados. 2016. (Apresentação de Trabalho/Simpósio).

3. FERNANDES, M. R.; NAKANO, V. . Resistência de Escherichia coli comensal, diarreiogênica e extra-intestinal em crianças colonizadas: características fenotípicas e genotípicas. 2015. (Apresentação de Trabalho/Conferência ou palestra).

4. FERNANDES,M.R; NAKANO, V. . A influência da antibióticoterapia na microbiota fecal de crianças em idade escolar. 2014. (Apresentação de Trabalho/Conferência ou palestra).

\section{Produção técnica}

\section{Entrevistas, mesas redondas, programas e comentários na mídia}

1. FERNANDES, M. R.; SILVA, Q. M. ; SARTORI, L. ; ESPOSITO, F. ; CERDEIRA, L. T. ; SABINO, C. P. ; LOPES, R. ; TURANO, H. ; LINCOPAN, N. . Combate ás Superbactérias. 2016.

\section{Demais tipos de produção técnica}

1.

FERNANDES,M.R; SILVA, Q. M. ; SARTORI, L. . Métodos para detecção de resistência bacteriana. 2016. (Curso de curta duração ministrado/Outra).

\section{Bancas}

Participação em bancas de trabalhos de conclusão

\section{Trabalhos de conclusão de curso de graduação}

1. FERNANDES, MIRIAM R.; SILVA, M.. Participação em banca de Shirley Alves Brombrim.Revisao de Literatura e Relato de Caso sobre Otoacaríase. 2018. Trabalho de Conclusão de Curso (Graduação em Medicina Veterinária) - Centro Universitário das Faculdades Metropolitanas Unidas.

\section{Eventos}

Participação em eventos, congressos, exposições e feiras

1. ASM Microbe. IncX4 plasmids are key vectors responsible for the dissemination of the mcr-1 gene among Escherichia coli from humans, animals, food and environment in Brazil. 2017. (Congresso).

2. XII Simpósio Estadual de Infecção Hospitalar Resistência Microbiana Associada às Infecções Relacionadas Assistência saúde. 2015. (Simpósio).

3. XXII Congreso Latinoamericano de Microbiología Y 4 Congresso Colombiano de Microbiología,. Perfil de susceptibilidade aos antimicrobianos de Escherichia coli comensal e diarreiogênica isoladas de amostras fecais de crianças sem diarreia.. 2014. (Congresso).

4. $\quad 270$ Congresso Brasileiro de Microbiologia. Influência da antibioticoterapia na microbiota intestinal endógena de crianças sem diarreia: análise preliminar. 2013. (Congresso).

5. Protein Day/ CEFAP USP. 2013. (Outra).

6. $\quad$ Workshop " How to write cleary" and " Publishing your science". 2013. (Outra).

7. IV Encontro de E. coli patogênica " Luis Rachid Trabilsi". 2012. (Encontro).

8. $\quad 1^{0}$ Simpósio da Área Médica do Instituto Adolfo Lutz: Pesquisa, Inovação e Vigilância E. 2011. (Simpósio). 
9. I I Simpósio de Meningites Bacterianas. 2011. (Simpósio).

10. Os desafios da AIDS, tuberculose e hanseníase frente à resistência antimicrobiana.. 2011. (Outra),

11. $\quad 44^{\circ}$ Congresso Brasileiro de Patologia Clínica / Medicina laboratorial. 2010. (Congresso).

12. 70 Congresso Paulista de Infectologia. 2010. (Congresso).

13. Ações integradas para Controle da Leishmaniose Visceral America e Projeto Legal para cachorro.. 2010. (Outra).

14. Clube de Bioquímica do Programa de Controle Interlaboratorial em Hematologia e Bioquímica do IAL. 2010. (Outra).

15. III Workshop Brasileiro de Hepatopatias e HIV. 2010. (Outra).

16. IV Congresso de Biomedicina da Baixada Santista. 2009. (Congresso).

17. III Congresso de Biomedicina da Baixada Santista. 2008. (Congresso).

18. VII Feira da Saúde e Educação.Feira da Saúde e Educação. 2008. (Outra).

19. VI Feira da Saúde e Educação.Feira da Saúde e Educação. 2007. (Outra).

20. I Congresso de Biomedicina da Baixada Santista. 2006. (Congresso).

Página gerada pelo Sistema Currículo Lattes em 24/07/2019 às 24:44:00

Imprimir currículo 